Latvijas Lauksaimniecības universitāte

Ekonomikas un sabiedrības attīstības fakultāte

Latvia University of Agriculture

Faculty of Ecomomics and Social Development

Latvijas

Lauksaimniecības

universitāte

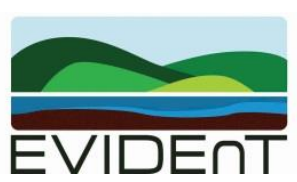

$M B A$ Arnis Lēnerts

\author{
SILTUMNĪCEFEKTA GĀZU EMISIJU \\ SAMAZINĀŠANA - LAUKSAIMNIECĪBAS \\ ILGTSPĒJĪGAI ATTİSTĪBAI LATVIJĀ
}

\title{
REDUCTION OF GREENHOUSE GAS EMISSIONS FOR SUSTAINABLE DEVELOPMENT OF AGRICULTURE IN LATVIA
}

\author{
Promocijas darba KOPSAVILKUMS \\ ekonomikas doktora (Dr.oec.) zinātniskā grāda iegūšanai \\ SUMMARY \\ of the Doctoral thesis for the scientific degree Dr.oec.
}

Autors/author (paraksts)

Jelgava 2018 


\section{INFORMĀCIJA}

Promocijas darbs izstrādāts Latvijas Lauksaimniecības universitātes Ekonomikas un sabiedrības attīstības fakultātes Ekonomikas un reǵionālās attīstības institūtā.

Doktora studiju programma - Agrārā un reǵionālā ekonomika, apakšnozare - Agrārā ekonomika.

Promocijas darba zinātniskā vadītāja - LLU Ekonomikas un sabiedrības attīstības fakultātes profesore, Dr.oec. Irina Pilvere.

\section{Promocijas darba zinātniskā aprobācija noslēguma posmā:}

$>$ Apspriests un aprobēts LLU Ekonomikas un sabiedrības attīstības fakultātes Ekonomikas un regionālās attīstības institūta akadēmiskā personāla pārstāvju sēdē 2017. gada 15. martā.

$>$ Apspriests un aprobēts LLU Ekonomikas un sabiedrības attīstības fakultātes Ekonomikas un reǵionālās attīstības institūta, Uzṇēmējdarbības un vadībzinātnes institūta, Finanšu un grāmatvedības institūta un Informācijas tehnologiju fakultātes Vadības sistēmu katedras akadēmiskā personāla pārstāvju apvienotā akadēmiskā sēdē 2017. gada 1. novembrī.

$>$ Atzīts par pilnīgi sagatavotu un pieņemts Promocijas padomē 2018. gada 15. martā .

\section{Oficiālie recenzenti:}

1. Dr.oec. Andra Zvirbule - promocijas padomes eksperte, Latvijas Lauksaimniecības universitātes Ekonomikas un sabiedrības attīstības fakultātes dekāne, profesore.

2. Dr.oec. Vera Komarova - neatkarīgā recenzente, Daugavpils universitātes vadošā pētniece.

3. Dr. Vlada Vitunskiene - neatkarīgā recenzente, Aleksandra Stulginskis universitātes Sabiedrības zinātņu fakultātes pētniece, profesore.

Promocijas darba aizstāvēšana notiks LLU Ekonomikas zinātņu nozares Agrārās ekonomikas un Reǵionālās ekonomikas apakšnozaru Promocijas padomes atklātā sēdē 2018. gada 1. jūnijā Ekonomikas un sabiedrības attîtīibas fakultātē (Svētes iela 18, Jelgava) 212. auditorijā plkst. 9:00.

Ar promocijas darbu var iepazīties LLU Fundamentālajā bibliotēkā, Lielā ielā 2, Jelgavā.

Atsauksmes sūtīt Promocijas padomes sekretārei - Svētes ielā 18, Jelgavā, LV-3001, tālr.63025170, e-pasts: anita.auzina@llu.lv. Atsauksmes vēlams sūtìt ieskenētā veidā ar parakstu.

Padomes sekretāre: LLU asociētā profesore Dr.oec. Anita Auziņa 


\section{INFORMATION}

The doctoral dissertation has been elaborated at the Institute of Economics and Regional Developement, Faculty of Economics and Social Development, Latvia University of Agriculture (LLU).

Doctoral Study Programme - Argarian and Regional Economics, sub-branch of science - Regional Economics.

Scientific supervisor of the doctoral dissertation: professor of Faculty of Economics and Social Development, LLU, Dr.oec. Irina Pilvere.

Scientific approbation of the doctoral thesis at the final stage:

$>$ Presented and discussed at the seminar of academic staff representatives of the Faculty of Economics and Social Development on March $15^{\text {th }}, 2017$.

$>$ Discussed and aprprobated at the interdepartmental meeting of academic staff of the Faculty of Economics and Social Development (Institute of Business and Management Science, Institute of Economics and Regional Development and Institute of Finance and Accounting) and Faculty of Information Technologies, LLU on November $1^{\text {th }}, 2017$.

$>$ Recognised and fully prepared and accepted by the LLU promotion Counsil for Economics, sub-brach - Agrarian and Regional Economics on March 15 th, 2018.

Official reviewers:

1. Dr.oec. Andra Zvirbule - expert of the Promotion Council, dean of the Faculty of Economics and Social Development of Latvia University of Agriculture, professor.

2. Dr.oec Vera Komarova - independent reviewer, Senior Researcher of University of Daugavpils.

3. Dr. Vlada Vitunskiene - independent reviewer, Researcher of the Aleksandras Stulginskis University, professor.

The defence of the doctoral thesis will be heald at the open meeting of theLatvia University of Agriculture Promotion Council for Economics, sub-branch of science - Agrarian and Regional Economics on June 1th, 2018 in Jengava, Svetes street 18, Faculty of Economics and Social Development, Room 212, at 9 a.m.

The doctoral thesis is avialable at the Fundamental Library of Latvia university of Agriculture, Liela street 2, Jelgava and foloving the link:

You are welcome to send your comments to the secretary of the Promotion Council - Svetes street 18, Jelgava, LV-3001, phone: +371 63025170; e-mail: anita aizina@llu.lv.It is advised to send your comments in a scanned form and undersigned.

Secretary of the Promotion council - Latvia University of Agriculture assoc. profesor, Dr. Oec. Anita Auziņa. 


\section{SATURS}

INFORMĀCIJA PAR PUBLIKĀCIJĀM UN ZINĀTNISKI PĒTNIECISKO

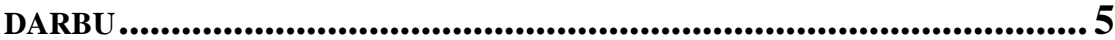

1.LAUKSAIMNIECĪBAS ILGTSPĒJĪGAS ATTİSTİBAS TEORĒTISKIE

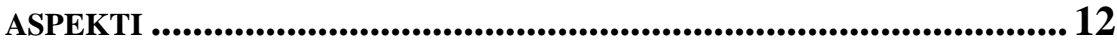

1.1.EKONOMIKAS ATTĪSTĪBAS UN IZAUGSMES JĒDZIENU TEORĒTISKAIS SKAIDROJUMS........12

1.2.DABAS KAPITĀLA IZMANTOŠANA EKONOMIKAS ATTĪSTĪBAS NODROŠINĀŠANAI ...........15

1.3. LAUKSAIMNIECĪBA EKONOMISKĀS ATTĪSTĪBAS KONTEKSTĀ ..................................... 17

1.4. ILGTSPĒJĪGA UN INTENSIFICĒTA LAUKSAIMNIECİ̈BA............................................ 21

2.LAUKSAIMNIECĪBAS UN VIDES POLITIKAS ATTĪSTĪBA, TIESISKAIS REGULĒJUMS UN INSTITUCIONĀLĀ VIDE ............................. 24

2.1. LAUKSAIMNIECĪBAS UN VIDES POLITIKAS SINERĢIJAS ATTĪSTİBA.............................25

2.2. LAUKSAIMNIECİBU REGLAMENTĒJOŠIE TIESĪBU AKTI LATVIJĀ ................................26

2.3. INSTITUCIONĀLĀ SISTĒMA LAUKSAIMNIECISKAS IETEKMES UZ VIDI NOVĒRTĒŠANAI ...28

3. LAUKSAIMNIECISKO RAŽOŠANU RAKSTUROJOŠIE RĀDĪTĀJI UN TO IETEKME UZ DABAS VIDI LATVIJĀ ......................................... 29

3.1. ZEMES IZMANTOŠANAS RAKSTUROJUMS LAUKSAIMNIECĪBĀ ....................................29

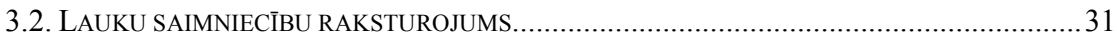

3.3. LAUKSAIMNIECISKĀ RAŽOŠANA UN TĀS RADĪTĀS SEG EMISIJAS ............................... 33

3.4. LAUKSAIMNIECİBAS SEG EMISIJU PIEAUGUMA PROGNOZE LATVIJĀ LĪDZ 2020. GADAM

4. AUGKOPĪ̈AS ILGTSPĒ JĪGA INTENSIFIKĀCIJA LAUKSAIMNIECĪBAS

ATTİSTİBAI LATVIJĀ

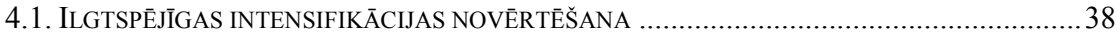

4.2. ILGTSPĒJĪGAS LAUKSAIMNIECĪBAS VEIDOŠANAS PIEMĒRI ...................................... 41

4.3. AUGKOPĪBAS ILGTSPĒJĪGAS INTENSIFIKĀCIJAS ATTĪSTĪBAS NOVĒRTĒJUMS LATVIJĀ....42

5. SEG EMISIJU SAMAZINĀŠANAS PASĀKUMI AUGKOPĪBĀ UN TO IETEKMES UZ DABAS UN EKONOMISKO VIDI IZVĒRTĒJUMS.......... 48

5.1. SEG EMISIJU ROBEŽSAMAZINĀJUMA IZMAKSU ANALİZE........................................ 49

5.2. AUGKOPĪBAS SEG EMISIJU SAMAZINĀŠANAS PASĀKUMU NEPIECIEŠAMĪBA ................51

5.3. LATVIJAS APSTĀKḶIEM PIEMĒROTI SEG EMISIJU SAMAZINĀŠANAS PASĀKUMI

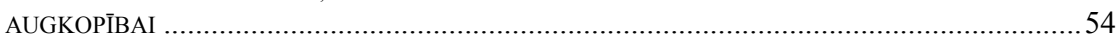

5.4. AUGKOPĪBAS SEG EMISIJU SAMAZINĀŠANAS PASĀKUMA ,SLĀPEKL̨A APRITES PRECĪZA

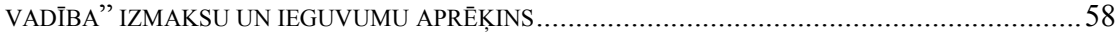

GALVENIE SECINĀJUMI...................................................... 62

PROBLĒMAS UN PRIEKŠLIKUMI TO RISINĀŠANAI ....................... 64 


\section{CONTENTS}

INFORMATION ON RESEARCH PAPERS AND SCIENTIFIC RESEARCH WORK....................................................................................66

INTRODUCTION.............................................................6 69

1.THEORETICAL ASPECTS OF AGRICULTURAL SUSTAINABLE

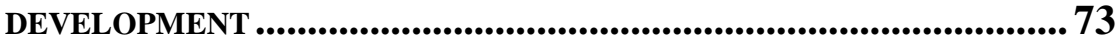

1.1. THEORETICAL EXPLANATION OF THE TERMS ECONOMIC DEVELOPMENT AND GROWTH 73

1.2. EXPLOITATION OF NATURAL CAPITAL TO ENSURE ECONOMIC DEVELOPMENT ..............76

1.3. AGRICULTURE IN THE CONTEXT OF ECONOMIC DEVELOPMENT .................................78

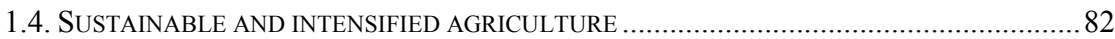

2.DEVELOPMENT OF AND THE LEGAL AND INSTITUTIONAL FRAMEWORKS FOR AGRICULTURAL AND ENVIRONMENTAL

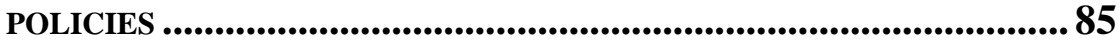

2.1. SYNERGY OF AGRICULTURAL AND ENVIRONMENTAL POLICIES ...................................86

2.2. LEGAL DOCUMENTS REGULATING AGRICULTURE IN LATVIA................................... 87

2.3. INSTITUTIONAL SYSTEM FOR ASSESSING AGRICULTURAL IMPACTS ON THE

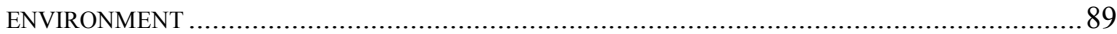

3.INDICATORS OF AGRICULTURAL PRODUCTION AND ITS IMPACTS ON THE NATURAL ENVIRONMENT IN LATVIA .............................90

3.1. CHARACTERISTICS OF LAND USE IN AGRICULTURE .......................................... 91

3.2. CHARACTERISTICS OF AGRICULTURAL HOLDINGS ................................................. 93

3.3. AGRICULTURAL PRODUCTION AND GHG EMISSIONS FROM IT ...................................94

3.4. Projection of agricultural GHG EMISSIONS IN LATVIA FOR THE PERIOD UP TO

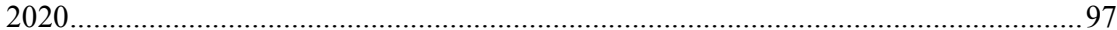

4.SUSTAINABLE INTENSIFICATION OF CROP PRODUCTION FOR AGRICULTURAL DEVELOPMENT IN LATVIA .............................. 99

4.1. ASSESSMENT OF SUSTAINABLE INTENSIFICATION .................................................. 99

4.2. EXAMPLES OF THE EMERGENCE OF SUSTAINABLE AGRICULTURE .............................. 102

4.3. ASSESSMENT OF THE DEVELOPMENT OF SUSTAINABLE INTENSIFICATION OF CROP

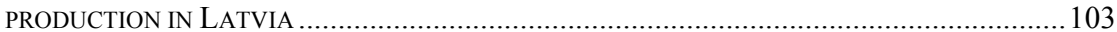

5. GHG EMISSION REDUCTION MEASURES IN CROP PRODUCTION AND AN ASSESSMENT OF THEIR EFFECTS ON THE NATURAL AND ECONOMIC ENVIRONMENTS .............................................. 110

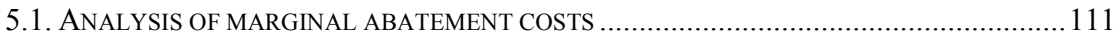

5.2. NECESSITY FOR GHG EMISSION REDUCTION MEASURES IN CROP PRODUCTION .......... 113

5.3. GHG EMISSION REDUCTION MEASURES APPROPRIATE FOR THE CONDITIONS IN LATVIA

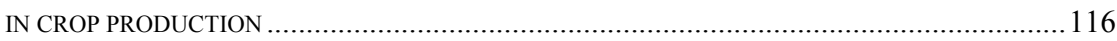
5.4. COST AND BENEFIT CALCULATIONS FOR THE GHG EMISSION REDUCTION MEASURE

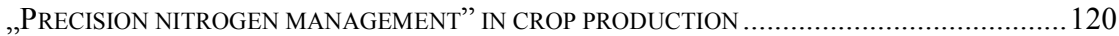

MAIN CONCLUSIONS .............................................................. 124

PROBLEMS AND PROPOSALS FOR THEIR SOLUTION..................... 126 GALVENO IZMANTOTO AVOTU SARAKSTS / REFERENCES USED IN THE SUMMARY.......................................................................... 128 


\section{INFORMĀCIJA PAR PUBLIKĀCIJĀM UN ZINĀTNISKI PĒTNIECISKO DARBU}

\section{Pētījuma rezultāti publicēti zinātniskajos izdevumos 16 rakstos, no tiem 7 raksti indeksēti SCOPUS un 7 Web of Science datubāzēes:}

1. Popluga D., Naglis-Liepa K., Lenerts A., Rivza P. (2017) Marginal abatement cost curve for assessing mitigation potential of Latvian agricultural greenhouse gas emissions: case study of crop sector. In: Ecology, Economics, Education and Legislation: Proceedings of the International Multidisciplinary Scientific Geoconference SGEM 2017. Vol. 17, pp. 511-518, ISSN 1314-2704. (Indeksēta Scopus, EBSCOhost Academic Search Complete).

2. Lenerts A., Popluga D., Schulte R.P.O., Pilvere I. (2017) Sustainability assessment of agricultural production: case study of Latvian crop sector. In: Engineering for Rural Development: Proceedings of the $16^{\text {th }}$ International Scientific Conference. Jelgava: LLU, Vol.16, pp. 1312-1320, ISSN 16915976. (Indeksēta Scopus, Crossref).

3. Lenerts A. Popluga D., Rivza P. (2017) Selection of greenhouse gas emission-reducing measures with analytical hierarchy process approach: a case study from Latvian crop production sector. In: Economics Science for Rural Development: Proceedings of the International Scientific Conference, Nr.44 (Bioeconomy). Jelgava: LLU, pp. 267-273, ISSN 1691-3078. (Indeksēta Web of Science, EBSCOhost Academic Search Complete).

4. Kreišmane D., Naglis-Liepa K., Popluga D., Lenerts A., Rivža P. (2016) Liming effect of nitrogen use efficiency and nitrogen oxide emissions in crop farming. In: Research for Rural Development 2016, 18-20 May: Proceedings of the Annual $22^{\text {nd }}$ International Scientific Conference, Jelgava, Latvia, 2016 / Latvia University of Agriculture. Jelgava, 2016, Vol. 1, pp. 30-36, ISSN 1691-4031. (Indeksēta Web of Science, EBSCOhost Academic Search Complete).

5. Popluga D., Kreišmane D., Naglis-Liepa K., Lenerts A., Rivža P. (2016) Fertilisation planning as effective tool for balanced economic and environmental benefits in crop farming. In: Research for Rural Development 2016, 18-20 May: Proceedings of the Annual $22^{\text {nd }}$ International Scientific Conference, Jelgava, Latvia, 2016 / Latvia University of Agriculture. Jelgava, 2016, Vol. 1, pp. 23-29, ISSN 16914031. (Indeksēta Web of Science, EBSCOhost Academic Search Complete).

6. Lenerts A., Popluga D., Naglis-Liepa K., Rivža P. (2016) Fertilizer use efficiency impact on GHG emissions in the Latvian crop sector. In: Biosystems Engineering 2016. 7th International Scientific Conference Tartu, Estonia, Journal Agronomy Research, pp. 123-133. ISSN 1406894X. (Indeksēta Scopus, Web of Science BIOSIS Citation Index, EBSCOhost Academic Search Complete, CAB Abstracts). 
7. Lenerts A., Berzins G., Popluga D. (2016) Nitrogen fertilizer use efficiency and GHG emissions in the Latvian grain sector. In: Engineering for Rural Development: Proceedings of the $15^{\text {th }}$ International Scientific Conference. Jelgava: LLU, pp. 224 - 229. ISSN 1691-5976. (Indeksēta Scopus, Web of Science, EBSCOhost Academic Search Complete, CABI).

8. Lēnerts A. (2015) Agriculture in Latvia: economic activity and GHG emissions. In: Zinatniski praktiska konference Lìdzsvarota lauksaimniecība. Jelgava: LLU, pp. 19-20. ISBN 9789984481760. (Indeksēta AGRIS, CAB Abstracts).

9. Lenerts A. (2015) Developement of Sustainable Intensification Evaluation Metodology for Farmlands in Latvia. In: Economics Science for Rural Development: Proceedings of the International Scientific Conference, Nr. 37 (Bioeconomy). Jelgava: LLU, pp. 160-171. ISSN 1691-3078. (Indeksēta Web of Science, EBSCOhost Academic Search Complete).

10. Pilvere I., Lenerts A. (2015) Agricultural GHG emission and mitigation measures in Latvia. In: Engineering for Rural Development: Proceedings of the $14^{\text {th }}$ International Scientific Conference. Jelgava: LLU, pp. $571-576$. ISSN 1691-5976. (Indeksēta Scopus, Web of Science, EBSCOhost Academic Search Complete, AGRIS).

11. Lenerts A., Popluga D. (2015) Facilitate Calculations of GHG Emissions in Latvian Agriculture at Farm Level. In: Ecology, Economics, Education and Legislation: Proceedings of the International Multidisciplinary Scientific Geoconference SGEM 2015. Volume III pp. 287-294. ISSN 1314-2704. (Indeksēta Scopus, Web of Science).

12. Popluga D., Naglis-Liepa K., Lenerts A. (2015) Latvia's Progress Towards Agricultural GHG Mitigation. In: Nordic View to Sustainable Rulral Developement. Proceedings of the NJF $25^{\text {th }}$ Congress, pp. 265-270. ISBN 978-9934-14-549-0. (Indeksēta Web of Science, CAB Abstracts, EBSCOhost Academic Search Complete).

13. Lenerts A., Strikis V. (2013) Bio-economy and a sustainable market for biofuels. In: Ecology, Economics, Education and Legislation: Proceedings of the International Multidisciplinary Scientific Geoconference SGEM 2013. Volume II pp. 49-56. ISSN 134-2704. (Indeksēta Scopus, Web of Science).

14. Lenerts A. (2013) Sustainable Use of Bio-resources of Agricultural Origin: The Basis of Bioeconomy in Latvia. In: Rural Development 2013: Innovations and Sustainability: Proceedings of the Annual $6^{\text {th }}$ International Scientific Conference. Volume 6, Book 1 pp. 209-214.ISSN 2345-0916. (Indeksēta Web of Science, EBSCOhost Academic Search Complete).

15. Lenerts A., Pilvere I. (2012) Role of Land Resources in the Development of the Market of Renewable Energy Sources of Agricultural Origin in Latvia. In: Economic Science for Rural Development: Proceedings of the International Scientific Conference. No. 29: Rural Business and Finance, pp. 73-79. 1691-3078. (Indeksēta Web of Science, EBSCOhost Academic 
Search Complete, EBSCOhost Central and Eastern European Academic Source, AGRIS).

16. Strīkis V., Kalniņš A., Lenerts A. (2012) Possibilities for renewable energy production on farms. In: Renewable Energy and Energy Efficiency: Proceedings of the International Scientific Conference. No.1: Economic and legislative aspects of the renewable energy production, pp. 231-234. 9789984-48-070-1. (Indeksēta Web of Science, CAB Abstracts, AGRIS).

Par pētijuma rezultātiem ziņots 13 starptautiskajās zinātniskajās konferencēs:

1. Lenerts A. Sustainability assessment of agricultural production: case study of Latvian crop sector. $16^{\text {th }}$ International Scientific Conference: Engineering for Rural Development. Jelgava, LLU (Latvija), 2017. gada 24. maijā.

2. Lenerts A. How sustainable is Latvia's agriculture? $16^{\text {th }}$ International Scientific Conference: Economic Science for Rural Development. Jelgava, LLU (Latvija), 2017. gada 28. aprīlī.

3. Lenerts A. Latvijas lauksaimniecībai piemērotu SEG emisiju samazināšanas pasākumu izvērtējums. Scientific and Practical Conference on Balanced Agriculture: Harmonious Agriculture. Jelgava, LLU (Latvija), 2016. gada 26. februārī.

4. Lenerts A. Nitrogen fertilizer use efficiency and GHG emissions in the Latvian grain sector. $15^{\text {th }}$ International Scientific Conference: Engineering for Rural Development. Jelgava, LLU (Latvija), 2016. gada 26. maijā.

5. Lenerts A. Developement of Sustainable Intensification Evaluation Metodology for Farmlands in Latvia. $16^{\text {th }}$ International Scientific Conference: Economic Science for Rural Development. Jelgava, LLU (Latvija), 2015. gada 23. aprīlī.

6. Lenerts A. Agricultural GHG emission and mitigation measures in Latvia. $14^{\text {th }}$ International Scientific Conference: Engineering for Rural Development. Jelgava, LLU (Latvija), 2015. gada 21. maijā.

7. Lenerts A. Facilitate Calculations of GHG Emissions in Latvian Agriculture at Farm Level. $15^{\text {th }}$ International Multidisciplinary Scientific GeoConference SGEM: Ecology, Economics, Education and Legislation. Albena, (Bulgaria), 2015. gada 19. jūnijs.

8. Lenerts A. Agriculture in Latvia: Economic Activity and GHG Emissions. Scientific and Practical Conference on Balanced Agriculture: Harmonious Agriculture. Jelgava, LLU (Latvija), 2015. gada 20. februārī.

9. Lenerts A. Sustainable Use of Bio-resources of Agricultural Origin: the Basis of Bioeconomy in Latvia. International Scientific Conference: Rural Development 2013: Innovations and Sustainability. Kauņa, ASU (Lietuva), 2013. gada 28. novembrī.

10. Lenerts A. Challenges of Bioeconomy. $6^{\text {th }}$ Jonas Pranas Aleksa International Scientific Conference: Contemporary Rural Vision. Šiauliai, Šiauliai Universitetas (Lietuva), 2013. gada 27. septembrī. 
11. Lenerts A. Bio-economy and a sustainable market for biofuels. $13^{\text {th }}$ International Multidisciplinary Scientific GeoConference SGEM: Ecology, Economics, Education and Legislation. Albena, (Bulgaria), 2013. gada 22. jūnijs.

12. Lenerts A. Role of Land Resources in the Development of the Market of Renewable Energy Sources of Agricultural Origin in Latvia. International Scientific Conference: Economic Science for Rural Development. Jelgava, LLU (Latvija), 2012. gada 27. aprīlis.

13. Lenerts A. Possibilities for renewable energy production on farms. International Scientific Conference: Renewable energy and energy efficiency. Jelgava, LLU (Latvija), 2012. gada 27. maijā.

\section{Sabiedriskā darbība saistībā ar promocijas darba tēmu:}

1. Izstrādāts un realizēts studiju kurss Bioekonomika LLU Ekonomikas un sabiedrības attīstības fakultātes akadēmiskās augstākās izglītības bakalaura studiju programmas „Ekonomika” studentiem.

2. Dalība LLU veiktajā pētījumā „Zemes ekonomiski efektīva, ilgtspējīga un produktīva izmantošana lauksaimniecības un mežsaimniecības produkcijas ražošanai".

3. Ar pētījuma rezultātiem iepazīstināta Latvijas Republikas 12. Saeimas ilgtspējīgas attīstības komisija 2017. gada 13. oktobra sēdē.

4. Autors piedalās Valsts pētījumu programmas projektā „Latvijas ekosistēmu vērtība un tās dinamika klimata ietekmē - (EVIDEnT)", Nr.2014/VPP20142017, kā pētnieks 2014. - 2018. gadā.

\section{IEVADS}

Mūsdienu tirgus ekonomikas apstākḷos valsts ekonomisko attīstību, tai skaitā arī lauksaimniecību un laukus, ietekmē virkne faktoru un dažādu tirgus dalībnieku intereses. Ir jāmeklē risinājums: kā nodrošināt pārtiku pieaugošajam iedzīvotāju skaitam; kā mazināt fosilo resursu izmantošanu; kā palielināt atjaunojamo resursu izmantošanu; kā ierobežot ekonomiskās aktivitātes radīto negatīvo ietekmi uz ekonomisko, sociālo un dabas vidi.

Latvijas teritorijā fosilie resursi (nafta, gāze) ir pieejami tikai teorētiski, tomēr valsts geogrāfiskais novietojums un klimats par īpaši vērtīgiem padara tās teritorijā esošos zemes resursus dažādas produkcijas ražošanai. Pēc Latvijas Centrālās statistikas pārvaldes datiem (CSP, 2015) lauksaimnieciskajai ražošanai ir pieejami 2.2 milj. ha lauksaimniecībā izmantojamās zemes (LIZ), un 2015. gadā pēc Lauku atbalsta dienesta (LAD) datiem lauksaimnieciskās produkcijas ražošanai tika izmantoti tikai 1.8 milj. ha LIZ. Latvijas ekonomikas izaugsmes nodrošināšanai ir svarīgi izmantot visas pieejamās LIZ platības. Šo resursu izmantošanas iespējas lauksaimniecības nozaru ekonomiskās izaugsmes kontekstā ir plaši pētîtas Latvijas zinātnieku darbos (Boruks A., 1982; Špoǵis K., 2007; Strīkiis V., 2013; Dobele A., 2005; Auziņš A., 2013; Pilvere I., 2015; Nipers A., 2015). Savukārt vairāki stratēǵiskie dokumenti un pamatnostādnes 
uzsver resursu ilgtspēju vai arī to izmantošanu ilgtspējīgas ekonomikas mērḳim.

Latvijas ilgtspējīgas attīstības stratēgijā līdz 2030. gadam (Latvijas ilgtspējīgas..., 2010) atzīts, ka Latvijas dabas kapitāls ir salīdzinoši labā stāvoklī, tomēr nepietiekami izmantots un apsaimniekots. Latvijas valsts Nacionālā attīstības plāna (NAP, 2012) viens no indikatīvajiem mērḳiem ir panākt, lai 2020. gadā lauksaimnieciskās produkcijas ražošanai tiktu izmantoti vismaz 2 milj. ha LIZ. Līdzīgs indikatīvais mērḳis ir iestrādāts Latvijas Lauku attīstības programmā 2014. - 2020. gadam (LAP, 2014). KLP finansēšanas fondu līdzekḷu izlietojuma ekonomisko novērtējumu Latvijā ir pētījuši vairāki autori (Pilvere I., 2012; Miglavs A.,Vēveris A., 2011; Upīte I., 2012; Tetere V., 2012). Vērtējot problemātiskos aspektus un būtiskos izaicinājumus lauksaimniecības ilgtspējai vides, sociālo un ekonomisko faktoru sabalansētībā, būtisks pagrieziena punkts procesu attīstîbai Latvijas lauksaimniecībā un laukos ir 2012. gadā pieņemtā ES stratēg̣ija „Inovācijas ilgtspējīgai izaugsmei: Eiropas bioekonomika". Lai ievērotu galvenos bioekonomikas principus, ir nepieciešama inovatīva, konkurētspējīga, resursu efektīva ražošana, kas spēj nodrošināt pieprasījumu pēc pārtikas un atjaunojamajiem bioresursiem, neradot papildu ietekmi uz ekonomisko, sociālo un dabas vidi (Inovācijas ilgtspējīgai izaugsmei..., 2012). Stratēgijas principu realizēšanai ir jāmeklē līdzsvars starp ražošanas procesu intensifikāciju un ilgtspējas principu ievērošanu. Lauksaimnieciskās ražošanas attīstības pamatā jābūt ilgtspējīgas intensifikācijas principiem. Lauksaimniecības ilgtspējīgas intensifikācijas attīstības problemātika ir pētīta citu valstu zinātnieku (Pretty J., 1997; David S., 1989; Webster P., 1999; van Calker K., 2007) darbos. Latvijas lauksaimniecības kontekstā atsevišķi zinātnieki (Dzene S., 2014) ir pievērsušies ilgtspējas jautājumu pētījumiem, kas ne vienmēr nozīmē lauksaimnieciskās ražošanas pieaugumu. Viens no sarežğîtākajiem uzdevumiem tuvākajā nākotnē lauksaimniekiem un zinātniekiem ir atrast konverǵējošas jeb līdzsvarotas dabas, ekonomiskās un sociālās vides attīstības iespējas lauksaimnieciskās ražošanas intensīvas izaugsmes situācijā, pieaugot siltumnīcefekta gāzu (SEG) ietekmei uz dabas vidi. Vēsturiski - objektīvu iemeslu dēl samazinoties lauksaimnieciskajai ražošanai pēc 1990. gada, arī SEG emisijas lauksaimniecībā samazinājās par $74 \%$ un 2005. gadā tās bija $2175 \mathrm{Gg} \mathrm{CO}_{2}$ eq (Latvian's National, 2015). Tomēr situācija strauji main̄̄sies pēc 2020. gada, jo saskaņā ar jauno indikatīvo mērķi Latvijā (Decision No 406, 2009) līdz 2030. gadam ir jāpanāk SEG emisiju samazinājums sektoros (tai skaitā lauksaimniecībā), kuri neietilpst ES emisiju tirdzniecības sistēmas (ne-ETS) sektoros, lai tas nepārsniegtu 2005. gada līmeni (2014. gada emisijas lauksaimniecībā - $2424 \mathrm{Gg} \mathrm{CO}_{2}$ eq.) (Decision No 406, 2009).

Tāpēc LIZ platību palielināšana Latvijā un noteiktā SEG samazināšanas mērķa sasniegšana ne-ETS sektoros, kā arī SEG emisiju pieaugums no lauksaimnieciskās darbības aktivitātēm un starptautiski uzṇemtās saistības ir 
aktualizējušas nepieciešamību meklēt šo procesu līdzsvarotas attīstības iespējas, nodrošinot:

$>$ ražošanā izmantoto LIZ platību pieaugumu - atklāt iespējas, kā lauksaimniekiem apstrādājamo zemju platību palielināšanu izmantot tikai konkurētspējīgas produkcijas ražošanai;

> SEG emisiju ierobežošanu - izstrādāt lauksaimnieciskās ražošanas tehnoloǵiskos procesus un ieviest SEG emisiju ierobežošanas un samazināšanas pasākumus, kuri nodrošinās lauksaimniecības uzṇēmumu ekonomisko ilgtspēju;

> starptautiski uzṇemto saistību izpildi - SEG emisiju samazināšana no lauksaimnieciskās darbības nedrīkst samazināt ekonomisko aktivitāti un līdz ar to arī ekonomikas attīstību lauku teritorijās Latvijā.

ES un pasaules zinātnieku darbos (Moran D., 2011; Eory V., 2015; Schulte R., 2012; Pellerin S., 2013) ir plaši pētìta lauksaimniecības un vides ilgtspēja caur emisiju samazinošo pasākumu īstenošanu, izvērtējot to ietekmi gan uz dabas un sociālo vidi, gan ražošanas ekonomiskajiem rādītājiem. Latvijā šādu pētījumu ir maz, un tāpēc darba autors izvēlējās šo tēmu, lai veiktu padzilịnātu novērtējumu līdzsvarotas attīstības jeb konverǵences iespējām lauksaimnieciskās ražošanas izaugsmei un augkopības ietekmes uz dabas vidi samazināšanai Latvijā.

Šāds situācijas izvērtējums ḷāva autoram izvirzīt zinātniskā darba hipotēzi augkopības ilgtspējīgas intensifikācijas rezultātā tiek samazinātas SEG emisijas un nodrošināta lauksaimniecības attīstība. Pêtījumā, ievērojot tā noteiktās robežas, kā pētijjuma objekts ir lauksaimniecības attīstība Latvijā, bet pētījuma priekšmets ir augkopības radīto SEG emisiju samazināšana.

Balstoties uz definēto zinātniskā darba hipotēzi, pētījuma objektu un priekšmetu, tika izvirzīts pētījuma mērḳis - izpētît lauksaimniecības ilgtspējīgas attīstības iespējas Latvijāa, ieviešot iespējamos SEG emisiju samazinošos pasākumus augkopībā.

Izvirzītā mērķa sasniegšanai ir definēti atbilstoši darba uzdevumi:

$>$ izpētīt lauksaimniecības ilgtspējīgas attīstības teorētiskos aspektus;

$>$ izanalizēt lauksaimniecības un dabas vides politiku, tiesisko regulējumu un institucionālo vidi;

> izvērtēt lauksaimnieciskās ražošanas attīstības rādītājus un to ietekmi uz dabas vidi;

$>$ izstrādāt lauksaimniecības ilgtspējīgas intensifikācijas aprēḳināšanas metodologiju un veikt augkopības attīstības novērtējumu;

$>$ novērtēt augkopības SEG samazinošo pasākumu ietekmi uz dabas un ekonomisko vidi Latvijā.

N̦emot vērā, ka ekonomika ir reālā, empīriskā zinātnes nozare, kas balstīta uz faktiem, datu iegūšanai tika izmantota statistiskā informācija no publiski pieejamām datu bāzēm, kura tika apstrādāta ar atbilstošām datu un informācijas apstrādes metodēm. Katram risināmajam darba uzdevumam tika pielietotas vairākas pētījumu metodes, izmantojot atbilstoši nodaḷā pētāmajai problēmai: 
$>$ lauksaimnieciskās ražošanas ekonomiskās attīstības un izaugsmes teorētisko aspektu un lauksaimnieciskās ražošanas radīto ārējo efektu (externality) mazināšanas politiskās, tiesiskās un institucionālās vides analīzei tika izmantotas vispārzināmās pētījumu metodes - analīze un sintēze, monogrāfiskā jeb aprakstošā, indukcija un dedukcija;

$>$ lauksaimnieciskās ražošanas attīstības un tās radīto SEG emisiju raksturojošo rādītāju ietekmējošo faktoru noskaidrošanai izmantotas analīzes un sintēzes metodes un matemātiskās pētījumu metodes statistisko rādītāju aprēkināšana, datu vispārināšana, laikrindu, korelācijas un regresijas analīze;

$>$ lauksaimnieciskās ražošanas ilgtspējīgas intensifikācijas indikatoru izmaiṇu tendenču analizēšanai izmantotas statistiskās analīzes (statistisko rādītāju aprēķināšana, grupēšana, sakarību analīze), kā arī datu analīzes un sintēzes metodes;

$>$ izstrādājot augkopības SEG samazināšanas pasākumu ietekmes ekonomisko un dabas vides novērtējumu, tika izmantotas vispārzinātniskās pētījumu metodes - analīze, sintēze, indukcija un dedukcija, ekspertu metode (kvalitatīivā un kvantitatīvā) un hierarhijas analīzes metode.

Pētījuma mērḳa sasniegšanai un izvirzīto uzdevumu risināšanai tika izmantoti informācijas materiāli:

$>$ starptautiskie dokumenti, ES, EK un Latvijas Republikas (LR) tiesiski normatīvie akti, stratēgiskie un politikas plānošanas dokumenti;

> Eurostat, LR Centrāāās statistikas pārvaldes (turpmāk tekstā - CSP) un citās datubāzēs publicētie dati un informācija;

$>$ speciālā zinātniskā literatūra, aktuālie pētījumi un publikācijas zinātniskajās datubāzēs par promocijas darba tēmu;

$>$ ekspertu novērtējuma rezultāti.

\section{Pētījuma ierobežojums}

Ekonomiskā aktivitāte lauku reǵionos ir būtisks faktors ekonomikas izaugsmei valstī. Lauksaimnieciskās ražošanas izaugsmi ietekmē tādi nozīmīgi faktori kā produktu pieprasījums un piedāvājums, resursu pieejamība, cenas, izmantotās tehnologijas un lauksaimniecības radītie ārējie negatīvie efekti emisiju veidā. Promocijas darbā visu šo faktoru ietekmes novērtējumu nav iespējams ietvert, tādēl lauksaimnieciskās ražošanas izaugsmes aspekti tiek pētīti augkopības radīto siltumnīcefekta gāzu negatīvo efektu kontekstā. Šādu izvēli noteica trīs būtiski apsvērumi: augkopībā tiek saražots lielākais lauksaimnieciskās produkcijas apjoms Latvijā un tajā izmanto galveno Latvijas dabas bagātību - zemi; pēc 2020. gada būtiski jāsamazina SEG emisijas lauksaimniecībā; līdz 2020. gadam jāpalielina platības, kurās tiek ražota lauksaimniecības produkcija.

\section{Pētījuma novitātes un zinātniskais nozīmīgums}

$>$ teorētisko un empīrisko pētījumu rezultātā daudzpusīgi izvērtēta augkopības ekonomiskās vides, sociālās vides, dabas vides un tehnologiju ilgtspēja Latvijā; 
$>$ pievēršoties starpdisciplināriem pētījumiem par augkopības līdzsvarotu attīstību, noskaidrotas galvenās lauksaimniecības attīstības tendences;

$>$ veikts aktuāls pêtījums par Latvijā salīdzinoši maz pētītu agrārās ekonomikas problēmu - augkopības izaugsmi ilgtspējīgas intensifikācijas apstākḷos - un izstrādāta ilgtspējīgas intensifikācijas novērtējuma metodologija;

$>$ veikts augkopības SEG emisiju samazināšanas pasākumu izmaksu un ieguvumu aprēkins.

\section{Pētījuma tautsaimnieciskā nozīme}

$>$ pētījums būtiski papildina augkopības attīstības teorētisko bāzi ilgtspējīgas intensifikācijas apstākḷıs;

$>$ pētījuma rezultātus varēs praktiski izmantot augkopības attīstības programmas izstrādei, kā arī tie būs noderīgi lauku saimniecībām lēmumu pieņemšanai.

\section{Aizstāvamās tēzes}

1. Lauksaimniecības attīstību nodrošina līdzsvarots cilvēku, dabas, finanšu un ražošanas kapitāla pieaugums.

2. Lauksaimniecības ilgtspējīgu attīstību nodrošina lauksaimniecības un vides politikas sinerǵija, kuras īstenošana balstās uz pieņemtajiem normatīvajiem aktiem un izveidotu institucionālo sistēmu.

3. Latvijas lauksaimniecība, it īpaši augkopība, dinamiski attīstās un veicina SEG emisiju veidošanos.

4. Augkopības ilgtspējīga intensifikācija samazina negatīvo ietekmi uz vidi, nodrošinot līdzsvarotu ekonomiskās, sociālās un dabas vides attīstību.

5. SEG samazinošo pasākumu ieviešana augkopībā nodrošinās dabas vides saglabāšanu un ekonomiskos ieguvumus lauksaimniecības ilgtspējīgai attīstībai.

\section{LAUKSAIMNIECĪBAS ILGTSPĒJĪGAS ATTĪSTĪBAS TEORĒTISKIE ASPEKTI}

Nodaḷas saturs darbā veidots no 27 lpp., kurās ietilpst 3 tabulas un 9 attēli. Nodaḷā izvērsta diskusija par jēdziena „ilgtspējīga lauksaimniecība” skaidrojumu. Pilnveidots lauksaimniecības ilgtspējīgas attīstības definējums. Raksturota bioekonomikas vieta un loma lauksaimniecības ilgtspējīgā attīstībā. Nodaḷā izvirzìtà tēze: Lauksaimniecības attīstìbu nodrošina līdzsvarots cilvēku, dabas, finanšu un ražošanas kapitāla pieaugums.

\subsection{Ekonomikas attīstības un izaugsmes jēdzienu teorētiskais skaidrojums}

Ekonomiskās izaugsmes teorijas attīstības posmi, kas atstājuši būtisku ietekmi uz lauksaimniecības izaugsmi un attīstību, ir šādi: 
Klasiskā jeb ekonomiskā liberālisma izaugsmes teorija (18. un 19. gs.) par šīs teorijas pamatlicējiem tiek uzskatīti A. Smits, D. Rikardo, A. Maršals, A. C. Pigu u.c., kuri uzskatīja, ka ekonomika vislabāk darbojas pati par sevi, ekonomiskos procesus veido tirgus „,neredzamā roka” un valstij ekonomiskajos procesos nav jāiejaucas. Šo ekonomistu idejas bija populāras līdz pat 20.gadsimta trīsdesmitajiem gadiem (Treisijs M., 1996).

Keinsiānisma ekonomiskās izaugsmes teorija (20. gs. 30. gadi) pamatlicējs Dž. M. Keinss. Teorija balstās uz atzinumu, ka valsts īstermiņa iejaukšanās ekonomiskajos procesos ar investīcijām, pārdomāti regulējot kopējo pieprasījumu, nodrošina ekonomikas izaugsmi ekonomisko krīžu laikā. Kā redzamākais šādas teorijas rezultāts bija Eiropas Kopējās lauksaimniecības politikas izveide. Šì teorija veiksmīgi tika realizēta arī Latvijā pirmās brīivvalsts laikā (Bērziņš-Valdess R. u.c., 1938). Vēlākajā laika posmā teoriju tālāk attīstīja neokeinsiānisma pārstāvji F. Modiljani, Dž. Tobins un G. Menkjū.

Monetārisma (neoliberālisma) ekonomiskās izaugsmes teorija (20. gs. 60. gadi) - teorijas aizsācējs M. Frīdmens uzskatīja, ka valsts loma ekonomikā ir jāsamazina. Dominēja uzskats, ka ekonomikas izaugsme ir atkarīga no stingras monetārās politikas realizēěanas. Šīs ekonomiskās izaugsmes teorijas rezultātā pasaulē aizsākās globalizācijas procesi un neierobežotā kapitāla plūsma, kas tika uzskatīta par galveno ekonomiskās izaugsmes faktoru, veicināja arī straujāku lauksaimniecības nozares attīstību. Tomēr galveno uzdevumu - vienlīizīgu labklājību visos pasaules reǵionos - sasniegt nav izdevies.

Neoliberālisma ekonomiskās izaugsmes teorētiḳi 20. gadsimta vidū sadalījās divos virzienos, un tieši Vācijas jeb Freiburgas skolas pārstāvji V. Euckens, F. Bohms un V. Ropke izveidoja ordoliberālisma novirzienu, kas vēlāk nozīmīgi ietekmēja lauksaimniecības attīstību Eiropā (Eise S., 2012).

Šajā periodā tika izstrādāti arī pirmie ekonomiskās attīstības modeḷi, par pamatu ņemot C.V. Koba un P. H. Duglasa izstrādāto Koba - Duglasa ražošanas funkciju, kuru tālāk attīstīja Nobela prēmijas laureāts Roberts Solovs. Gan keinsiānisma, gan monetārisma teorijās attīstība tiek uzskatīta par eksogēnu, jo teorija paredz ārējās ietekmes nepieciešamību, piemēram, piesaistîto investīciju veidā.

Endogēnā ekonomiskās izaugsmes teorija (20. gs. 90. gadi). Autori M. Todoro, K. Arous, P. Romers u.c. izstrādāja teoriju un pierādīja, ka ir iespējama ilgtermiņa pieauguma attīstība pie stacionāra stāvokḷa ekonomikā, ja tiks izmantoti tehniskā progresa, pieaugošas ražošanas atdeves un cilvēkkapitāla attīstības faktori.

Meklējot risinājumus eksogēnās un endogēnās izaugsmes teoriju pielietošanas līdzsvaram reālajā tautsaimniecībā, un, lai novērstu nepilnības ekonomiskajā attīstīibā, tiek attīstīta konverǵences koncepcija.

Alternatīvās ekonomiskās izaugsmes teorija (20. gs. 70. gadi). Izstrādājot alternatīvus ekonomiskās izaugsmes scenārijus, ir izveidojušies divi pretēji viedokḷi. Zinātnieki (Georgescu-Roegen N., 1971; Meadows D.H., 1972) 
formulēja domu, ka pieaugoša (ražošanas un patērina) ekonomiskā aktivitāte rada nepieciešamību pēc papildu resursu patēriņa, kas rada lielākus ražošanas blakusproduktus atkritumu veidā, un tā rezultātā veidojas vides piesārṇojums, mazinot iedzīvotāju dzīves kvalitāti un labklājību (Daly H., 1991). Romas kluba zinātnieku publicētajā darbā „Izaugsmes robežas” (Limits to Growth, 1972) tiek pierādīts, ka tieksme uz ekonomisko izaugsmi ir jāpārtrauc, lai saglabātu saimniecisko darbību vispār, jo resursu un vides noplicināšanas rezultātā tā neizbēgami samazināsies. Pēc autora domām, šāda pieeja vēl vairāk saasinātu lauku teritorijas attīstības problēmas. Alternatīvās ekonomiskās izaugsmes teorijas attīstītāji savos modelıos izmanto S. Kuzneta izvirzìto hipotēzi, ka sākotnējā ekonomikas attīstības fāzē ietekme uz vidi ievērojami pieaugs, bet, pieaugot iedzìvotāju labklājībai līdz noteiktam līmenim, ietekme uz vidi samazināsies (Rothmans S., 1998). Darba autors uzskata, ka dabas, ekonomiskās un sociālās vides uzlabošanas pasākumi, kurus ievieš lauksaimniecības produkcijas ražošanas sistēmā, nodrošina pieaugošu ražošanas faktoru produktivitāti un veicina lauksaimniecības nozares izaugsmi un attīstību ietekmes uz vidi kontekstā. Ir pierādīts, ka ekonomiskie ieguvumi no SEG emisiju samazināšanas ir lielāki par izmaksām to samazināšanai (Dudek D., 2002).

Zinātniskajā literatūrā, analizējot ekonomiskos procesus, autori lieto jēdzienus „ekonomikas attīstība” un „ekonomikas augsme/izaugsme”. Terminus lieto, lai apzīmētu dažādas, atšķirīgas izmaiņas ekonomikā. Svarīgi ir izprast atšķirības starp šiem jēdzieniem. Jēdziena „ekonomikas attīstība” skaidrojums ekonomikas vārdnīcā (Rutherford D. et al., 2002) ir formulēts divējādi:

$>$ ekonomikas virzība no lauksaimnieciskās ražošanas, kas pielieto vienkāršu tehnologiju, uz rūpniecisko ražošanu un plašu pakalpojumu klāstu, pielietojot modernu tehnologiju;

$>$ kumulatīvs (uzkrājošs) ienākuma pieaugums uz vienu iedzīvotāju, ko pavada strukturālas un institucionālas izmainas.

Pamatojoties uz ekonomiskās domas attīstības izpēti, promocijas darbā tiek piedāvāta lauksaimniecības ilgtspējīgas attīstības definīcija.

Ilgtspējīga lauksaimniecības attīstība ir virzība uz konvergenences līdzsvara stāvokli, kas realizējas $k \bar{a}$ - lìdzsvarota dabas, ekonomiskās un sociālās vides attīistība, kuru nosaka dabas kapitāla, finanšu kapitāla, ražošanas kapitāla un cilvēkkapitāla vērtības pieaugums lauksaimniecībā.

Darba autors, analizējot ekonomiskās izaugsmes attīstības teoriju, secināja, ka, pastāvot vienlaikus vairākiem konkurējošiem attīstības modeḷiem, ir kopīga pazīme tajos ietvert ārējos negatīvos efektus, kuri parādās dabas vidi raksturojošu kvalitatīvo rādītāju veidā. Izstrādājot lauksaimnieciskās ražošanas ekonomiskās attīstības modeḷus, nozīmīgi ir izprast procesā iesaistìto subjektu darbības izvirzîtā mērḳa sasniegšanai. Ideālā gadījuma iespējamība, kad neregulēts brīvais tirgus (tajā skaitā lauksaimniecībā) spēs atrisināt visas pretrunas, kādas pastāv tirgus ekonomikā, ir tikai teorētiska. Tas nozīmēe, ka ir 
jāattīsta Latvijas lauksaimniecības endogēnās izaugsmes teorētiskais modelis, kurā svarīga ir konverǵences jeb līdzsvarotas attīstības iespēju definēšana lauksaimnieciskās ražošanas izaugsmei un ietekmes uz dabas vidi samazināšanai.

\subsection{Dabas kapitāla izmantošana ekonomikas attīstības nodrošināšanai}

Darba autors, pamatojoties uz ekonomiskās attīstības teorijas izpēti, secina, ka ir mainījusies izpratne makroekonomikas (globālā) līmen̄̄ par ražošanas procesos izmantojamajiem resursiem. Raksturojot ekonomiku kā zinātnes nozari, autori ir izmantojuši terminu ,ierobežoti resursi”. Tuvākās nākotnes uzdevums ir novērtēt dabas kapitāla (dabas un vides resursu) vērtību un iekḷaut to vienotajā tirgus sistēmā. Zinātnieki I. Sundars (2012), J. Pretijs (2011), G. Akerlofs (1970), N. Georgesku-Roegens (1971) un citi ir vienoti viedoklī, ka dabas kapitāla vērtības atjaunošana ir pamats ilgtspējīgai ekonomikas attīstībai un cilvēku labklājības izaugsmei.

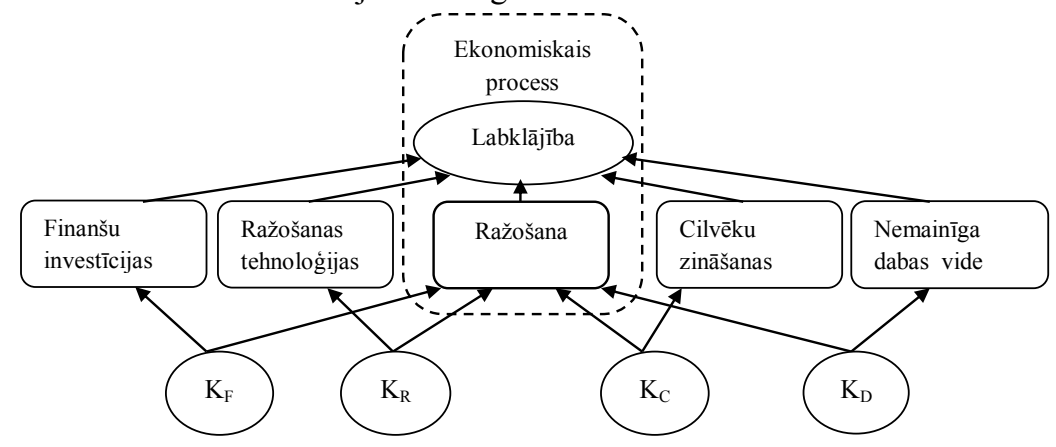

Avots: autora konstrukcija

1. att. Kapitāla mijiedarbība ekonomiskajos procesos.

Attēlā 1 ir atspogulota ražošanas procesā izmantotā kapitāla mijiedarbība. Cilvēka radītais un uzkrātais finanšu kapitāls $\left(\mathrm{K}_{\mathrm{F}}\right)$, ražošanas kapitāls $\left(\mathrm{K}_{\mathrm{R}}\right)$ un cilvēku kapitāls $\left(\mathrm{K}_{\mathrm{C}}\right)$, kā arī dabas $\left(\mathrm{K}_{\mathrm{D}}\right)$ kapitāls tiek izmantots ekonomiskajos procesos, lai veicinātu cilvēku labklājības pieaugumu, ražojot preces un sniedzot pakalpojumus. Lauksaimnieciskajā ražošanā dabas kapitāla izmantošana ir ražošanas procesa neatnemama sastāvdaḷa. Ražošanai tiek izmantots dabas kapitāls, kas ir ražošanas resursu avots (LIZ) un neapšaubāmi svarīgākais ražošanas faktors. No LIZ izmantošanas tieši būs atkarīgs ekonomiskā procesa rezultāts. Tomēr vienlaikus šis ražošanas resurss ir dabas kapitāla daḷa, kurai ir jānodrošina ekosistēmu pakalpojumi. Ir jānovērtē lauksaimnieciskās ražošanas procesā radītā ietekme uz dabas kapitālu un ekosistēmas spēja nodrošināt tā atjaunošanos. Šādā kontekstā ir svarīgi nodrošināt optimālu barības vielu apriti lauksaimniecībā izmantotajās agroekosistēmās, kas tieši var ietekmēt klimata izmainas. Ražošanas procesā 
lauksaimniecībā veidojas piesārņojošas emisijas apkārtējā vidē, un tās samazina dabas kapitāla vērtību, kas vienlaikus samazina cilvēku dzīves kvalitāti, tādējādi bremzējot ekonomisko attīstību, jo labumu no šāda ekonomiskā procesa neiegūst katrs sabiedrības loceklis. Dabas kapitāla novērtēšanu veic, nosakot kādas ekonomiskās vērtības preces un pakalpojumus var saražot ekosistēma, izmantojot esošo dabas kapitālu (Bartelmus P., 2008). Pamatojoties uz dabas kapitāla ekoloğiskajām un ekonomiskajām funkcijām, tiek noteikti ekosistēmas sniegtie pakalpojumi, kurus iedala 6 grupās (Common International Classification of Ecosystem Services - CICES) (European Environment..., 2011):

$>$ attīî̌̌sana un filtrācija - nodrošina gaisa, ūdens un augsnes attīrī̌šnu;

$>$ aprites procesi - barības vielu aprite, slāpekḷa fiksācija, oglekḷa piesaistīšana, augsnes veidošanās;

$>$ regulēšana un stabilizācija - kaitēkḷu un slimību kontrole, klimata regulēšana, vētras un plūdi, erozijas kontrole, nokrišņi un ūdens apgāde;

$>$ biotopi - patvērums dzīvniekiem un augiem, genētiskā materiāla glabātava;

$>$ apgāde un ražošana - biomasas ražošana izejvielām un pārtikai, apputeksnēšana un sēklu izplatība;

$>$ informācija un kultūra - estētiskā, atpūtas, kultūras un garīgā nozīme, izglìtība un pētniecība.

Lauksaimnieciskā ražošana būtībā ir dal̨a no kopējās ekosistēmas un var būtiski ietekmēt tajā notiekošos procesus. Izmantojot ekosistēmas pakalpojumu novērtēšanas ekonomiskās metodes, tiek noteikta lauksaimniecības agroekosistēmas sniegtā kopējā ekonomiskā vērtība (KEV). Galveno rādītāju izmaiņas ir būtiskas lēmumu pieņemšanā par LIZ lietojuma maiņu vai attiecībā uz darbībām, kas ietekmē agro-ekosistēmu stāvokli un to sniegtos pakalpojumus. Agro-ekosistēmas pakalpojuma KEV veidojas, nosakot gan ar tā izmantošanu saistīto vērtību, gan vērtību, kas netieši gūta no tās izmantošanas.

Tiešā izmantošanas vērtība ir cilvēka mijiedarbība ar ekosistēmu, kas dod peḷnu produktu veidā (biomasa, derīgie izrakteņi, ūdens) vai pakalpojuma veidā (atpūta, izglìīība).

Netiešā izmantošanas vērtība ir ekosistēmas pašsaglabāšanās spējas, barības vielu aprite, klimata stabilizācija, og̣̣skābās gāzes piesaiste, uzkrāšana, kā arī pievilcīga ainava un cilvēka neizmainīta dabas vide.

Nelietošanas vērtība - nosaka ieguvumus, ko sniedz ekosistēmu pastāvēšana, saglabāšana un iespējamā izmantošana negūstot materiālo labumu.

Novērtējot agro-ekosistēmas pakalpojumu KEV lauksaimniecībā, aprēķinātā labuma guvēji ir jāsadala interešu grupās. ES tiek izdalīti trīs labuma guvēju līmen̦i: lokālais (pagasts/novads), reǵionālais (Latvija) un pasaules/globālais mērogs. Novērtējot lauksaimniecības sektora agroekosistēmas KEV, galvenais rādītājs ir LIZ, proti, augsnes izmantošanas kvalitatīvie rādītāji. Lauksaimnieciskajai ražošanai Latvijā tiek izmantotas arī organiskās augsnes (kūdraina augsne), kas ir būtisks SEG emisiju avots Latvijā. Apstrādājot aramzemi, kas atrodas augsnēs ar augstu organisko vielu saturu 
(organisko vielu slānis ir biezāks par $10 \mathrm{~cm}$ ), notiek aktīva uzglabātā oglekḷa izdalī̌̌anās nitrifikācijas procesu rezultātā. Šie procesi veicina klimata pārmaiņas globālajā līmenī.

Lauksaimniecības sektora agro-ekosistēmas KEV noteikšana organiskajām augsnēm dod iespēju novērtēt iespējamos ieguvumus klimata pārmainuu mazināšanai, kā arī iespējamos zaudējumus lauksaimniekam ar zemes lietošanas veida maiņu no aramzemes uz zālājiem, kas bez finansiāla atbalsta nav iespējams.

Pie noteikta lauksaimniecības zemes izmantošanas veida var panākt SEG emisiju samazināšanu lauksaimniecībā.

\subsection{Lauksaimniecība ekonomiskās attīstības kontekstā}

Dažādos vēstures posmos zemes resursu izmantošanas efektivitāte, kas ir galvenā dabas kapitāla daḷa, ir bijusi atšḳirīga. Statistikas dati rāda, ka 2015. gadā lauksaimniecības nozares īpatsvars ES attīstīto valstu kopējā iekšzemes kopprodukta (IKP) struktūrā ir robežās no 1.1\% līdz 4\% (Agriculture in the..., 2016). Rādītāji attēloti 2. attēlā.

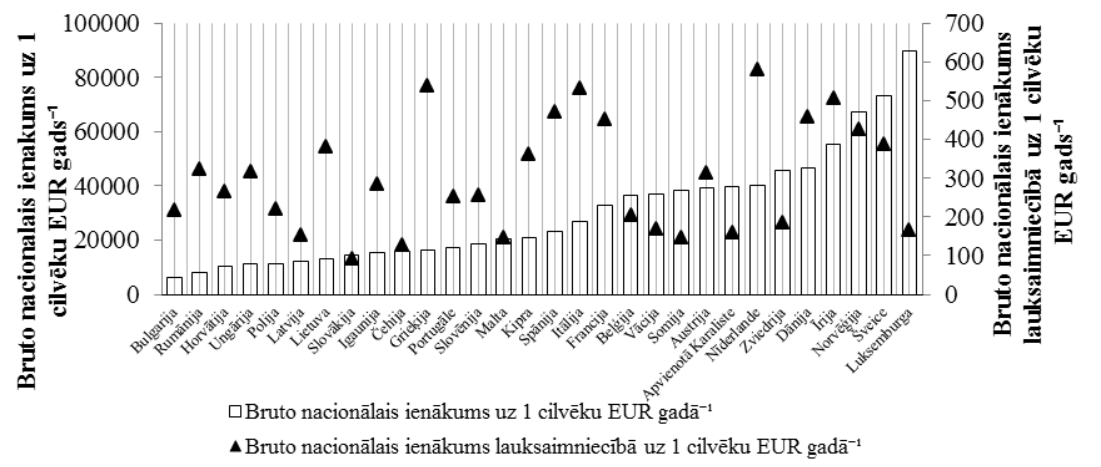

Avots: autora konstrukcija pēc Eurostat, 2015

2. att. Bruto nacionālais ienākums un iegūtais no lauksaimniecības uz vienu cilvēku Eiropas valstīs 2015. gadā, EUR gads'

Profesors K. Špogis (2007) ir norādījis, ka... „lauksaimniecības un mežsaimniecības loma Latvijas tautsaimniecībā ir organisko vielu ražošana un energijas uzkrāšana, pārtikas ražošana, izejvielu avots rūpnieciskajai pārstrādei un lauku, mežu apvidi dzīvojamai un atpūtas telpai”. Būtībā profesors netieši ir norādījis, ka lauksaimniecība kopā ar mežsaimniecību ir Latvijas bioekonomikas pamats.

Straujas izmainas lauksaimniecībā ir ieviesusi pasaules ekonomikas globalizācija. ES 28 valstīs laika posmā no 2005. gada līdz 2015. gadam pilna laika nodarbināto skaits lauksaimniecībā samazinājies par 25\%. Lielākais pilna laika nodarbināto skaita samazinājums ir konstatēts Bulgārijā 60\%, Rumānijā 50\%, Latvijā un Igaunijā 45\% (Agricultural Labour..., 2015). 
Apkopojot informāciju un konstruējot lauksaimniecības attīstības posmus darba autors secina, ka lauksaimniecības ražošanas attīstība tās klasiskajā periodā galvenokārt notika ekstensīvi, palielinot apstrādājamo zemju platības. Tika veikti atsevišķi mēǵinājumi lauksaimniecībā saražotās izejvielas izmantot nepārtikas produktu ražošanai. Nākamajā attīstības posmā, no 1960. gada līdz 1999. gadam, lauksaimnieciskā ražošana un lauku teritorijas kopumā piedzīvoja ievērojamas ekonomiskās izmaiņas. Pasaules ekonomiski attīstītākās valstis, t.sk. ES, meklējot risinājumus lauksaimnieciskās produkcijas apjomu kāpināšanai, izvēlējās ražošanas intensifikāciju. Pēc 2000. gada pasaules attīstītajās valstīs un ES lauksaimnieciskajai ražošanai tiek meklēti jauni ekonomiskās attīstības veidi. Noteikti var prognozēt tehnoloǵiju turpmāku attīstību, jo pastāv ievērojama atškirība Eiropas valstu lauksaimnieciskās ražošanas produktivitātes rādītājos pēc ES paplašināšanās 2004. gadā. Lai gan Latvijā lauksaimnieciskajā ražošanā ir viens no straujākajiem produktivitātes pieaugumiem ES, tomēr produktivitāte lauksaimniecībā 2015. gadā joprojām ir 16 reizes zemāka kā Nīderlandē un 5 reizes atpaliek no ES valstu vidējā rādītāja.

Lai noteiktu, cik cieša ir saistība starp valsts ekonomikas attīstību, kuru raksturo bruto nacionālais ienākums uz vienu cilvēku gadā, un lauksaimniecības attīstību, kuru raksturo saražotā produkcija vērtības izteiksmē uz vienu lauksaimniecībā nodarbināto, tika veikta šo rādītāju korelācijas analīze. Kopējie Eiropas valstu lauksaimniecības produktivitātes rādītāji 2015. gadā ir apkopoti 3. attēlā.

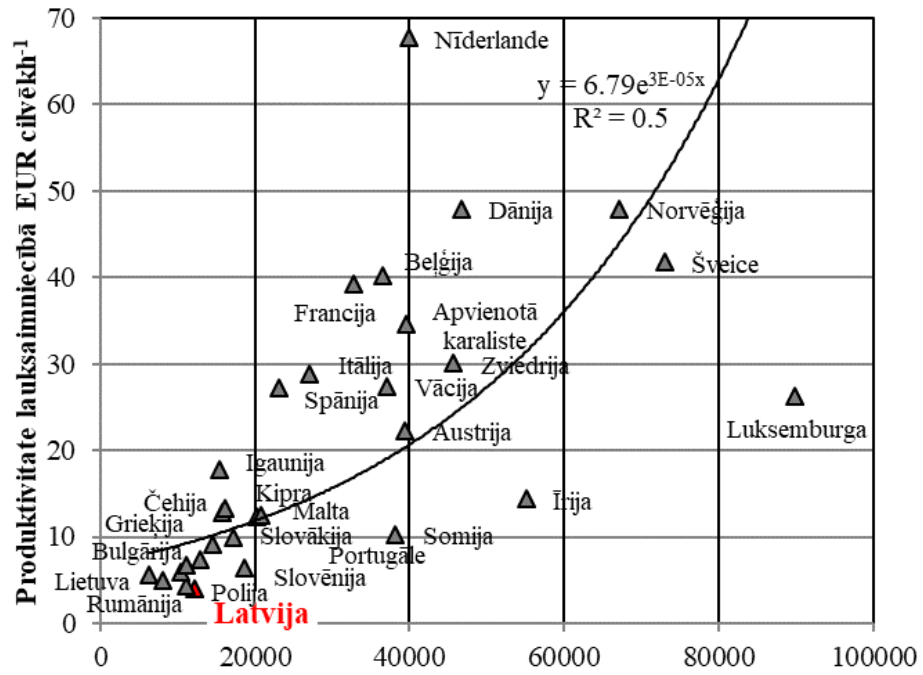

Bruto nacionālais ienākums uz 1 cilvēku EUR gads ${ }^{-1}$

Avots: autora konstrukcija pēc Eurostat, 2015

3. att. Korelācija starp Eiropas valstu lauksaimniecības produktivitātes un bruto nacionālo ienākumu uz 1 cilvēku 2015. gadā, EUR. 
Ir novērojama vidēji cieša $\left(\mathrm{R}^{2}=0.5\right)$ sakarība starp produktivitātes rādītājiem lauksaimniecībā un bruto nacionālo ienākumu uz vienu cilvēku Eiropas valstīs. Pēc autora domām var prognozēt, ka ekonomikas attīstībai investīcijas lauksaimniecības modernizācijā arī Latvijā turpināsies līdzīgi kā citās attīstītajās valstīs un, nodarbināto skaitam samazinoties, augs produktivitāte. Tomēr produktivitātes pieaugums ir saistīts ar ražošanā izmantoto resursu apjoma pieaugumu. Tāpēc augkopības nozarē produktivitātes pieaugumam ir jāveicina LIZ ilgtspējīga izmantošana, kas nozīmētu LIZ izmantošanu ar mērḳi radīt iespējami mazāko kaitējumu dabas videi piesārņojošo emisiju veidā.

Izvērtējot lauksaimniecības attīstības posmus Latvijā un pasaulē, iezīmējas tās loma ekonomikas attīstībā, bet mūsdienās palielinās nepieciešamība pēc ilgtspējīgas attīstības principu ievērošanas un nodrošināšanas. Ilgtspējas kā jēdziena un katra indivīda atbilstoša rīcība ir cieši saistīta ar ekonomikas attīstību (Sarma V., 2012).

Ilgtspējīga attīstība ir tāda attīstība, kur šodienas vajadzību apmierināšana neapdraud nākamo paaudžu iespējas apmierināt savējās. Ilgtspējība (sustainability) ir jēdziens, kurš eksistē kopš 1955. gada, un Rasela-Einšteina manifestā (The Russell Einstein..., 1955) pirmo reizi apzināti tika runāts par tādas attieksmes nepieciešamību, kas spētu nodrošināt politisko atbildību nākotnes paaudžu priekšā. vides.

Ilgtspējīgai attīstībai ir trīs dimensijas - ekonomiskā, sociālā un dabas

Tas nozīmē, ka ekonomiskā attīstība notiek, saudzīgi rīkojoties ar visiem pieejamajiem resursiem un rūpējoties, lai pieaugtu dabas kapitāla, sociālā kapitāla, finanšu kapitāla un ražošanas kapitāla vērtība. Visu kapitāla veidu vērtības pieaugums nodrošinās ilgtspējīgu attīstību š̄ jēdziena visplašākajā nozīmēe, un veicinās sabiedrības kopējo labklājību sniedzot ikvienam cilvēkam iespēju dzīvot ilgtspējīgā vidē apmierinot savas vēlmes un vajadzības.

Ilgtspējīgas attīstības termina definīcija un skaidrojums atrodams ANO G̣enerālās Asamblejas 1982. gadā apstiprinātajā „Pasaules dabas hartā” (World Charter for...,1982). Vēsturiski par ilgtspējīgas attīstības koncepcijas pirmsākumu tiek uzskatīts ANO Vides un attīstības komisijas jeb Bruntlandes komisijas 1987. gadā izstrādātais ziņojums „Mūsu kopīgā nākotne”, pazīstams arī kā Bruntlandes ziņojums (The World Commision..., 1987).

Pagrieziena punkts ilgtspējīgas attīstības koncepcijas veidošanās procesā bija Pasaules zemes samits, kas notika 1992. gada jūnijā Riodežaneiro (World Earth..., 1992). Klimata pārmaiņu konvencijas ieviešanai 1997. gada nogalē tika pieņemts Kioto protokols, kuru LR Saeima ratificēja 2002. gadā. Virzoties uz ilgtspējīgu lauksaimniecību, ES 1991. gada pieņēma Nitrātu direktīvu, kas ir viens no pirmajiem ES tiesību aktiem par piesārṇojuma kontrolēšanu un ūdens kvalitātes uzlabošanu un ilgtspējīgu dabas resursu izmantošanu (Direktīva..., 1991). Nākošais svarīgais posms virzībai uz ilgtspējīgu attīstību Eiropā ir ES pieņemtā stratēǵija „Eiropa 2020: stratēgija gudrai, ilgtspējīgai un iekḷaujošai izaugsmei" (Eiropa 2020). 
Ilgtspējīga ekonomiskā attīstība notiek, saudzīgi rīkojoties ar pieejamajiem resursiem un rūpējoties par to, lai uz Zemes tiktu saglabāta biologiskā daudzveidība. Ilgtspējīga attīstība veicina sabiedrības kopējo labklājību un sniedz ikvienam cilvēkam iespēju dzīvot labi saglabātā dabas vidē, realizējot savas vēlmes un vajadzības. Konvencijas par biologisko daudzveidību 2 . punktā ir dots termina ,ilgtspējīga izmantošana” skaidrojums, nosakot, ka tas „,nozìmē biologiskās daudzveidības sastāvdalı izmantošanu tādā veidā un tādos daudzumos, kas nenoved pie biologiskās daudzveidības samazināšanās perspektīvā, tādējādi uzturot tās iespējas apmierināt mūsdienu un nākamo paaudžu vajadzības un centienus".

Pēc 2000. gada, zemei kā ražošanas resursam veidojās alternatīvas izmantošanas iespējas. Lauksaimniecībā izmantojamo zemi sāka izmantot nepārtikas produktu ražošanai. Aktuāla kḷuva diskusija par to, vai, izmantojot zemi nepārtikas produktu ražošanai, pasaule spēs nodrošināt ar pārtiku pieaugošo iedzīvotāju skaitu uz zemeslodes (WWF, 2010).

Latvijas geogrāfiskais novietojums un tās teritorijā pieejamie resursi pēc autora domām ir uzskatāmi par salīdzinošām priekšrocībām, lai veiksmīgi konkurētu ar citām valstīm globālās ekonomikas apstākḷos. Analizējot galvenos lauksaimniecības ekonomiskās attīstības rādītājus Eiropas valstīs, var secināt, ka ražošanas izaugsmei Latvijā ir objektīvs pamats. Būtiska nozīme, izstrādājot nākotnes attīstības stratēgiju, ir bioekonomikai. Tās mērkị ir izveidot inovatīvu ekonomiku, kas rada zemas $\mathrm{CO}_{2}$ emisijas un veido līdzsvaru starp tādiem faktoriem kā ilgtspējīga lauksaimniecība, mežsaimniecība, zivsaimniecība nodrošinātība ar pārtiku un atjaunojamo biolog̣isko resursu izmantošana rūpniecībā, tajā pašā laikā veicinot biolog̣isko daudzveidību un saudzējot vidi.

Bioekonomika ir progresīva starpdisciplināra zinātnes nozare, kas cenšas integrēt ekonomikas zinātnes disciplīnu un biolog̣iju ar vien̄̄go mērḳi - radīt labāku teoriju, izskaidrojot ekonomikas procesus, izmantojot biotehnologijas zinātnisko pamatu. Bioekonomika ir paradigmu maiņa ekonomikas attīstībai un iekḷauj vienotā sistēmā dabas resursu ekonomiku, vides ekonomiku un ekologijas ekonomiku (Akerlof G., 1970).

Bioekonomika tiecas integrêt biomasas plūsmu no dažādām nozarēm tādā veidā, ka vienas industrijas atkritumi vai blakusprodukti kḷ̂ust par citas ražošanas nozares izejvielu. Šì pieeja ir līdzeklis, lai izveidotu efektīvas materiālu plūsmas kaskādes un vienlaikus novērstu klimata pārmaiņu un resursu noplicināšanas problēmas (OECD, 2010; EuropaBio, 2010).

Bioekonomikas attīstība balstās uz biotehnologiju zinātnisku izpēti. Nepieciešama ir nevis vienkārša fosilo resursu nomain̄̄šana ar atjaunojamajiem resursiem, bet gan paradigmas maiņa ekonomiskajā domāšanā (KBBE, 2010).

Bioekonomikas un biotehnologiju attīstîba nodrošinās uz zināšanām balstītu bioproduktu izstrādi, attīstību un augošu pieprasījumu. Šāda pieeja lauksaimniecības nozarē saražoto bioresursu pārstrādē ieviesīs tehnoloğiskās izmaiņas un augošu resursu atdevi (Reinert E., 2007). 


\subsection{Ilgtspējīga un intensificēta lauksaimniecība}

Darba autoram pētot lauksaimniecības attīstības vēsturiskos procesus, skaidri iezīmējas kopsakarība starp lauku vides attīstību un izmaināām ekonomiskajā domāšanā. Lauksaimniecība ar tās specifisko ražošanas veidu ir unikāla kopējās ekonomiskās, vides un sociālās sistēmas daḷa. Galvenais lauksaimniecības uzdevums un mērķis ir saražot pārtiku iedzīvotājiem. Analizējot š̄ mērḳa izpildi globālā kontekstā, darba autoram ir jāatzīst, ka situācija dažādos pasaules reǵionos ir atšķirīga. Pēc zinātnieku veiktajiem aprēķiniem 7 miljardu iedzīvotāju nodrošināšanai ar pārtiku ir nepieciešams izmantot: 1/3 no sauszemes agro-ekosistēmām; aptuveni $1 / 2$ no saldūdens krājumiem, kā arī dubultot slāpekḷa un fosfora pieejamo daudzumu vidē (Vitousek P.M., 1997). Veicinot globālās ekonomikas izaugsmi, lauksaimniecība ir nonākusi sarežǵīta attīstības cikla sākumā, jo saražotās produkcijas pieprasījuma pieaugums ir jānodrošina, izmantojot ilgtspējas principu ievērošanu, sākot no produkcijas ražošanas, tālāk to pārstrādājot un piegādājot galapatērētājiem (Charles H., 2010).

Darba autors izvirza četrus galvenos kritērijus ilgtspējīgas un intensificētas lauksaimniecības raksturojošajiem rādītājiem: 1) rādītājs identificēe, novērtē un raksturo sistēmas stāvokli; 2) rādītājs ḷauj prognozēt sistēmas attīstību un mērḳa sasniegšanu; 3) rādītājs sniedz informāciju par veiktās darbības efektivitāti; 4) rādītājs nodrošina informāciju sistēmā iesaistìtajām sabiedrības sociālajām grupām.

Ekstensīva lauksaimniecības attīstība globālā mērogā vienkārši vairs nav iespējama, jo nav pieejamas piemērotas zemes lauksaimniecībai, un pieaugošais pārtikas pieprasījums jānodrošina, intensificējot ražošanu. Savukārt lauksaimniecības ražošanas intensifikācija ir radījusi pieaugošu tās ietekmi uz klimata izmaiņām, kas savukārt, ir pretrunā ar ilgtspējīgas attīstības principiem. Lauksaimniecības attīstības definīcijā tiek ietverti divi neatdalāmi atslēgas vārdi „ilgtspējīga” un ,intensificēta” attīstība, un tās mērǐsanai tiek noteikti četri galvenie virzieni: 1) paaugstināt katra izmantotā zemes nogabala efektivitāti; 2) saglabāt un paaugstināt katra izmantotā zemes gabala vērtību; 3) samazināt ražošanā izmantoto resursu apjomu; 4) paaugstināt ekosistēmu sniegto pakalpojumu vērtību.

Autors piedāvā lauksaimniecības ilgtspējīgas intensifikācijas definīciju: ilgtspējīga intensifikācija ir lauksaimniecībā izmantotā ražošanas sistēma, kad produkcijas ražošanas apjomu pieaugumu panāk esošajās lauksaimniecībā izmantotajās zemes plat̄̄bās, nesamazinot dabas kapitāla agro-ekosistēmas esošo vērtību.

Sistēma, kuras ieviešanu ir atzinusi Latvijas valsts, ratificējot Kioto protokolu, paredz, ka globāli sasniedzamais klimata izmaiņu samazināšanas mērḳis ir jāpārnes un jāpiemēro arī zemākos līmeņos, sadalot to pa ne-ETS sektoriem. Katram sektoram tiek noteikti SEG emisiju radītāji. Lauksaimniecības uzṇēmumiem ir jābūt gataviem spēt novērtēt ražošanas 
ietekmi uz dabas vidi, jo ES līmenī tiek veikti pētījumi par SEG emisiju kvotu tirdzniecības vai SEG sertifikātu ieviešanas sistēmu ne-ETS sektoros (Lenerts A., 2015). Tomēr augstāk, autoraprāt, ir vērtējami zinātniskie pētījumi, kas aptver visu ilgtspējas kategoriju rūpīgu mijiedarbības izpēti, lai atrastu zemes resursu izmantošanas risinājumus, kuri līdzsvaro sociāli ekonomisko un ekosistēmas pakalpojumu sniegšanu (Pretty J., 2011; Foley J., 2011; Geraldo M.B., 2012).

Pēc autora veiktās izpētes ir secināms, ka nesaskaņas par ilgtspējīgas intensifikācijas novērtējumu vēl nav atrisinātas (Pretty J., 2014). Ilgtspējas novērtēšanas metožu salīdzinājums ir apkopots 1 . tabulā.

1. tabula

Vājās un stingrās ilgtspējas novērtēšanas atškiiīibas

\begin{tabular}{|c|c|c|}
\hline Ilgtspējas mērḳis & Vājā ilgtspēja & Stingrā ilgtspēja \\
\hline $\begin{array}{l}\text { Ekonomikas } \\
\text { izaugsme }\end{array}$ & $\begin{array}{l}\text { Kvantitatīvo rādītāju } \\
\text { pieaugums }\end{array}$ & $\begin{array}{l}\text { Limitēts kvantitatīvo radītāju } \\
\text { pieaugums }\end{array}$ \\
\hline Kapitāla uzturēšana & $\begin{array}{l}\text { Kopējā kapitāla izmantošanas } \\
\text { summa ir konstanta }\end{array}$ & $\begin{array}{l}\text { Kopējā un dabas kapitāla } \\
\text { summa ir konstanta }\end{array}$ \\
\hline $\begin{array}{l}\text { Dabas kapitāla } \\
\text { saglabāšana }\end{array}$ & $\begin{array}{l}\text { Var tikt aizvietots ar citu } \\
\text { kapitāla formu }\end{array}$ & $\begin{array}{l}\text { Nevar tikt aizvietots ar citu } \\
\text { kapitāla formu, jo ir } \\
\text { ierobežots }\end{array}$ \\
\hline $\begin{array}{l}\text { Ilgtspējas } \\
\text { sasniegšana }\end{array}$ & $\begin{array}{l}\text { Ražošanas faktoru } \\
\text { izmantošanas efektivitātes } \\
\text { pieaugums (tehnologija, } \\
\text { izaugsme, tirgus) }\end{array}$ & $\begin{array}{l}\text { Izaugsmes ierobežošana; } \\
\text { mērķtiecīgas politikas } \\
\text { ieviešana efektivitātes } \\
\text { sasniegšanai }\end{array}$ \\
\hline Nākotnes attīstība & $\begin{array}{l}\text { Ekonomikas sistēma (dabas } \\
\text { kapitāla efektīva izmantošana) }\end{array}$ & $\begin{array}{l}\text { Vides agro-ekosistēma } \\
\text { (dabas kapitāla vērtības } \\
\text { pieaugums) }\end{array}$ \\
\hline $\begin{array}{l}\text { Vides stāvokḷa } \\
\text { novērtējums }\end{array}$ & $\begin{array}{l}\text { Ražošanas faktoru avots } \\
\text { cilvēku labklājības } \\
\text { nodrošināšanai }\end{array}$ & $\begin{array}{l}\text { Pamats cilvēku izdzīvošanai } \\
\text { un eksistencei }\end{array}$ \\
\hline
\end{tabular}

Avots: autora konstrukcija pēc Kaphengst T., 2014

Lauksaimnieciskajā ražošanā ilgtspējas jēdzienu raksturo trīs savstarpēji saistītas dimensijas: lauku vides saglabāšana, ekonomiski pamatota lauku saimniecību darbība un nodarbinātība laukos.

Izvirzot mērkii radīt ilgtspējīgu lauksaimnieciskās ražošanas ekonomiskās attīstības modeli, ir nepieciešams novērtēt ilgtspējas dimensijas raksturīgāko rādītāju izmaiṇu dinamiku. Šos rādītājus izmanto, lai noteiktu, kādus ārējos efektus rada ekonomiskā modeḷa maiņa.

Lai realizētu pieņemto ilgtspējīgas attīstības stratēǵiju mērḳus samazināt SEG emisiju no lauksaimniecības Eiropas valstīs (Decision..., 2009), jāṇem vērā iespējamā sabiedrības indivīdu rīcība resursu izmantošanas, pārvaldīšanas, taupī̌sanas un saglabāšanas politikas realizēšanā. Izmantojot Kramera Dž. (Cramer J., 2007) izstrādāto metodiku, darba autors izvēlējās katras ilgtspējas dimensijas raksturīgākos rādītājus un novērtēja Latvijas lauksaimnieciskās 
ražošanas attīstîbu. Ilgtspējīgu vides dimensiju raksturo ražošanā izmantoto resursu pieaugums, kuriem ir lielākā ietekme uz vides piesārṇojumu. Lauksaimniecībā tie ir fosilās izcelsmes minerālmēsli un to radītās $\mathrm{CO}_{2}$ emisijas. Ilgtspējīgu ekonomisko dimensiju raksturo saražotās lauksaimniecības produkcijas fizisko rādītāju izmaiņas augkopībā un lopkopībā. Ilgtspējīgu sociālo dimensiju novērtē, izmantojot nodarbinātības rādītāja izmainas lauksaimniecībā. Aprēkināto attīstības indikatoru mijiedarbība attēlota 4. attēlā.

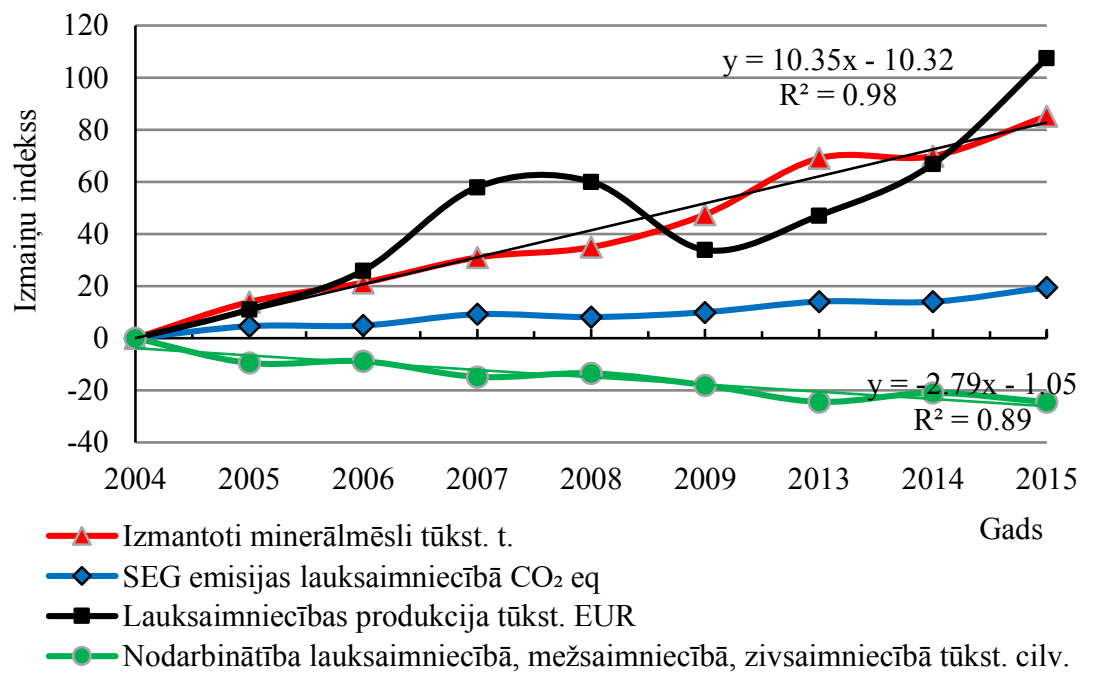

Avots: autora konstrukcija, izmantojot CSP datus, 2015

4. att. Lauksaimniecības attīstību raksturojošie izmainu indeksi $(2004=100)$

\section{Latvijā 2004. - 2015. gadā.}

Latvijas lauksaimniecības attīstības indikatori norāda uz problemātisku ilgtspējīgas ekonomiskās attīstības mērḳu sasniegšanu. Pētāmajā periodā izmantoto minerālmēslu daudzums palielinājās par 10 tūkst. t., bet nodarbināto skaits samazinās par 2.7 tūkst. cilvēku ik gadu. Lai arī kopš iestāšanās ES 2004. gadā ir sasniegta lauksaimnieciskas produkcijas izlaides izaugsme, ir pieaugusi arī ietekme uz vidi (SEG emisijas no lauksaimnieciskās darbības). Ražošanas intensificēšanai augkopībā ir izmantoti fosilie resursi (minerālmēsli). Būtiski ir samazinājusies nodarbinātība, radot sociāla rakstura riskus lauku teritorijās. Lauksaimnieciskās ražošanas izaugsme ir radījusi ārējos efektus, kuri ilgtermin̄à apdraud ilgtspējīgas attīstības principu ievērošanu. Lauksaimnieciskās ražošanas izaugsmi nevar uzskatīt par ekonomisko attīstību, jo tā nav nodrošinājusi labklājības pieaugumu ikvienam sabiedrības loceklim Latvijas valstī.

Autoraprāt, lauksaimniecības nozares spēja pielāgoties jaunajai klimata izmaiņu politikai, kura no rekomendējošas ir kḷuvusi par saistošu, var būtiski ietekmēt attīstību Latvijā. Lielāko ietekmi uz lauksaimnieciskās ražošanas attīstību veido emisiju samazināšanas pasākumi. 


\section{LAUKSAIMNIECĪBAS UN VIDES POLITIKAS ATTİSTĪBA, TIESISKAIS REGULËJUMS UN INSTITUCIONĀLĀ VIDE}

Nodalıas saturs darbā veidots no 17 lpp., kurās ietilpst 1 tabula un 6 attēli.

Nodą̣ā izvērsta analīze par lauksaimniecības un dabas vides politikas attīstības sinerğiju. Veikta lauksaimniecību un dabas vidi reglamentējošo tiesību aktu analīze. Raksturota institucionālā sistēma lauksaimniecības ietekmes uz vidi novērētēšanai.

Nodal̦āa izvirzītā tēze: Lauksaimniecības ilgtspējīgu attīstību nodrošina lauksaimniecības un vides politikas sinerğija, kuras ìstenošana balstās uz pieñemtajiem normatīvajiem aktiem un izveidotu institucionālo sistēmu.

Lauksaimniecībā, pēckara Rietumeiropā, praksē tika ieviests jauns tirgus ekonomikas modelis (Eise S., 2012). Vienā tirgus ekonomikas modelī tika apvienoti divi škietami pretrunīgi faktori: brīvais un valsts regulēts tirgus, tika radīta sociālā tirgus ekonomika (Joerges C., 2004). Šāda ekonomikas modeḷa funkcionēšana balstās uz īpašas politikas pieņemšanu. Patlaban ES ir uzṇēmusies vadošo lomu lauksaimniecības ilgtspējīgas attīstības politikas veidošanā. 2001. gadā Gēteborgā tika izstrādāta un 2006. gadā papildināta ES Ilgtspējīgas attīstības stratēgija. 2006. gadā Eiropas Komisija nāca klajā ar nozīmīgu dokumentu energètikas jomā - Zaḷo grāmatu (European Commission, 2006).

2016. gadā lauksaimnieciskās ražošanas jautājumi ir ietverti kopējā ES attīstības stratēg̣ijā „Eiropa 2020”, un tāpēc nozarē saistošas ir iniciatīvas „Inovācijas savienība” un „Resursu ziņā efektīva Eiropa” izvirzīto mērķu sasniegšana. Klimata izmaiņu mazināšanas un enerǵētikas mērḳis (20/20/20) iekḷauj SEG emisiju samazinājumu 2020. gadā par 20\% salīdzinājumā ar 1990. gadu, $20 \%$ enerğijas iegūšanu no atjaunojamiem energoresursiem, kā arī energoefektivitātes paaugstināšanu par $20 \%$, kas tieši attiecas arī uz lauksaimniecību (Direktīva, 2009). Atbilstoši kopējam ES mērḳim tiek noteikti katras dalībvalsts mērḳi ar fiksētiem rezultatīvajiem rādītājiem (Decision, 2009).

ES iniciatīvas „Resursu ziņā efektīva Eiropa” izvirzīto mērķu sasniegšana balstīta uz Klimata un enerǵijas politikas maiņu. Politika balstās uz četriem pîlāriem, un katram no tiem ir izstrādāts atbilstošs normatīvais regulējums:

$>$ ES Emisiju tirdzniecības sistēmas (ETS) stiprināšana un paplašināšana, kas ir galvenais rīks emisiju samazināšanai ekonomiski izdevīgā veidā. Paredzēts, ka 2020. gadā ETS aptverto sektoru emisijas tiks samazinātas par $21 \%$, salīdzinot ar 2005. gada līmeni. ETS tiks izveidots vienots ietvars ES, un emisiju kvotu piešḳiršana bez maksas līdz 2020. gadam pamazām tiks aizstāta ar kvotu izsoli;

$>$ emisijas no sektoriem, kuri nav iekḷauti ES ETS, - transports, mājsaimniecības, lauksaimniecība un atkritumu apsaimniekošana (ne-ETS 
sektori) - līdz 2020. gadam tiks samazinātas par 10\% salīdzinājumā ar 2005. gada līmeni. Katrai dalībvalstij saskaņā ar tās relatīvo labklājības līmeni jāuzstāda nacionālo emisiju samazināšanas mērḳi diapazonā no $20 \%$ bagātākajām dalībvalstīm līdz $+20 \%$ nabadzịgajām valstīm, lai sasniegtu kopējo plānoto emisiju samazinājumu;

$>$ saistoši mērḳi atjaunojamo energoresursu (AER) patēriņam kopējā energoresursu galapatēriņa struktūrā. Vidēji ES š̄ daḷa ir noteikta $20 \%$ 2020.gadā (vairāk nekā divkāršs no AER ražotās enerǵijas daļas pieaugums galapatēriņā, salīdzinot ar 2006. gadu, kad AER dą̧a bija 9.2\%). Katrai valstij noteiktie saistošie mērķi ir atšḳirīgi un svārstās no 10\% AER daḷai galapatēriņā Maltai līdz 49\% Zviedrijai;

$>$ plānots izveidot oglekḷa uztveršanas un uzglabāšanas staciju tīklu līdz 2020. gadam.

Izvirzịto SEG emisiju samazinājuma mērḳu sasniegšana ir problemātiska İrijā, Austrijā, Somijā, Beḷgijā un Spānijā, bet Latvija ir to valstu grupā, kurām jāizstrādā papildu pasākumi samazinājuma mērḳa sasniegšanai.

\subsection{Lauksaimniecības un vides politikas sinerğijas attīstība}

Dabas kapitāla izmantošana lauksaimnieciskajai ražošanai, ieviešot sociālo tirgus ekonomikas modeli, tiek regulēta, īstenojot KLP. Dabas kapitāla izmantošana lauksaimniecības attīstības nodrošināšanai labi atspoguḷojas KLP vēsturiskajos attīstības posmos.

KLP un vides politikas vēsturisko attīstības posmu sinerǵija ir apkopota 5. attēēā.

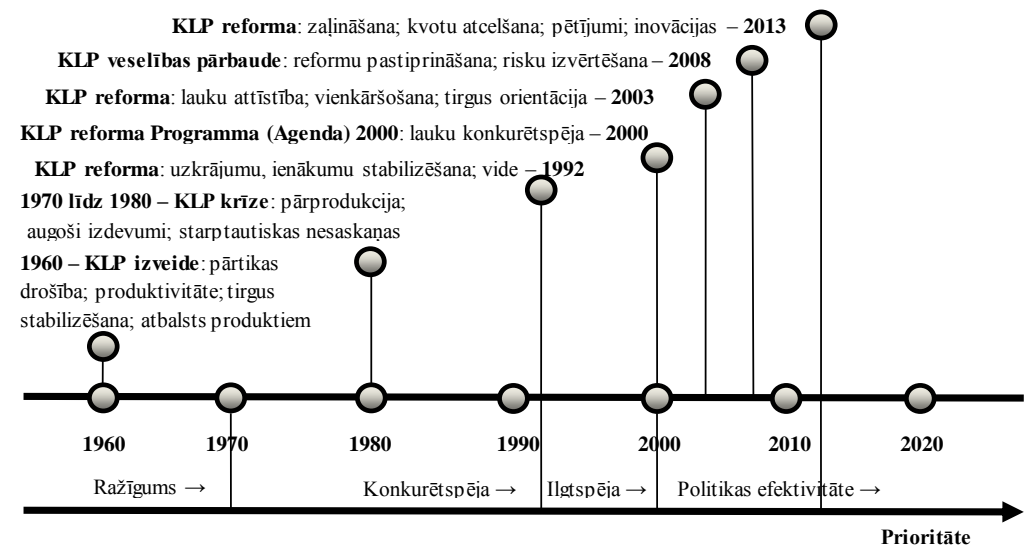

Avots: autora konstrukcija

5. att. ES lauksaimniecības un vides politikas sinerğijas attīstība līdz 2020. gadam. 
Lauksaimniecībā, realizējot KLP mērḳus par konkurētspējīgu, ilgtspējīgu un vidi saudzējošu attīstību, notika virzība uz lauksaimniecības preču tirgus liberalizāciju, mazinot valsts regulējošo lomu tajā. Ilgtspējīgu un vidi saudzējošu attīstību realizēja, izveidojot apjomīgu atbalstu biodegvielas ražošanai no lauksaimniecības izejvielām $\left(\mathrm{CO}_{2}\right.$ kredīts, atbalsts enerǵijas augiem). Latvijai iestājoties ES, kā viens no veicamajiem uzdevumiem bija biodegvielas (bioetanola un biodīzel̦degvielas) ražošanas uzsākšana. Vēlākajos gados strauji attīstìjās biogāzes ražošana no lauksaimniecības izejvielām.

\section{KLP reforma 2013. gadā}

Reforma, ko īstenoja 2013. gadā, bija jaunākais KLP pielāgošanas procesa posms, un tas joprojām nav pabeigts. Tā ieviesusi jaunu struktūru tiešajos maksājumos, mērḳtiecīgāku, zaḷāku, drošības tīklu veicinošu un pastiprinātu lauku attīstību (European Commission, 2013). ES KLP pamatnostādnes laikposmam no 2014. gada līdz 2020. gadam attiecas uz faktoriem, ar kuriem lauksaimniecība un lauki sastopas ekonomiskās attīstības un izaugsmes ceḷā.

Laika periodā no 2014. līdz 2020. gadam ES KLP tika noteikti savstarpējās atbilstības ievērošanas priekšnosacījumi saistībā ar maksājumu par klimatam un videi labvēlīgu lauksaimniecības praksi jeb „zaḷo komponenti” - tiešo maksājumu obligāta komponente, kam jāatvēl $30 \%$ no tiešo maksājumu kopējās summas un kas tiek piešḳirta kā papildu maksājums visiem vienotā platību maksājuma saṇēmējiem, ja tie ievēros attiecīgās prakses, kas vērstas uz klimata izmainu mazināšanu, biologiiskās daudzveidības nodrošināšanu, vides aizsardzību, $\mathrm{CO}_{2}$ emisiju mazināšanu un piesaisti. Ir iezīmēti trīs galvenie virzieni: kultūraugu daudzveidība - noteiktas platības aramzemē jāsēj noteikts skaits kultūraugu sugu; ilggadīgo zālāju saglabāšana - tiešajiem maksājumiem pieteiktajās platībās jāsaglabā noteikts apjoms zālāju platību; ekoloǵiskas nozīmes teritoriju izveidošana - jānodrošina noteiktas dalas aramzemes apsaimniekošana atbilstoši ekoloǵiskās nozīmes teritorijas pamatprincipiem (European Commission, 2013; Frelih-Larsen A., 2014).

\subsection{Lauksaimniecību reglamentējošie tiesību akti Latvijā}

Svarīgākais ES KLP mērḳu sasniegšanā ir atbilstoši izstrādāta un apstiprināta katras dalībvalsts tiesību aktu sistēma, kura ir saskaņota ar atbilstošajiem starptautiskajiem un ES tiesību aktiem.

Lauksaimniecība, ņemot vērā tās specifiskos produkcijas ražošanas apstākḷus, ir regulētākā uzṇēmējdarbības nozare. Lauksaimniecību dabas kapitāla izmantošanas kontekstā reglamentē dažādos laika posmos pieṇemtie dokumenti: konvencijas, starptautiskie līgumi, ES direktīvas un regulas, LR likumi, Ministru kabineta noteikumi, politikas plānošanas dokumenti un programmas. Lai strukturētu lauksaimniecību ietekmējošos, regulējošos un reglamentējošos tiesību aktus, autors ir izvirzījis trīs tai saistošas grupas. Pirmo grupu veido vispārējie komercdarbībai saistošie likumi, kas attiecas uz grāmatvedību un nodokḷiem, tiesiskajiem darījumiem un komercdarbību. Otro 
grupu veido lauksaimniecību reglamentējošās starptautiskās konvencijas, ES regulas un LR likumi. Trešajā grupā ir apkopotas starptautiskās konvencijas, ES regulas un LR likumi kas reglamentē vides (dabas kapitāla) izmantošanu un aizsardzību.

Analizējot lauksaimniecību reglamentējošos tiesību aktus Latvijā, par pamatu tiek ņemta spēkā esošā Lauku attīstības programma 2014. 2020. gadam. Izstrādātā Lauku attīstības programma ir reglamentējošo tiesību aktu hierarhijas svarīgākais dokuments, un tas ietver ES un starptautiski pieņemtos tiesību aktus, kuri nosaka lauku un lauksaimniecības attīstību Latvijā.

ANO Vispārējā konvencija par klimata pārmaiṇām veido būtisku ietekmi uz lauksaimniecību Latvijā. 1992. gadā pieņemtā Konvencija un Kioto protokols, kas ir ratificēts LR Saeimā, uzliek par pienākumu samazināt SEG emisijas, kuru dēl notiek globālā sasilšana. Atbilstoši Kioto protokolam Latvijai līdz 2020. gadam ir noteikti SEG emisiju samazināšanas mērksi salīdzinājumā ar 1990. gadu. Lēmumu pieņemšanas un reglamentējošo tiesību aktu izstrādes gaita, kas notiek saskaņoti ar šo rekomendāciju un attiecas uz lauksaimniecībā radīto SEG emisiju ierobežošanu raksturota 6 . attēlā.

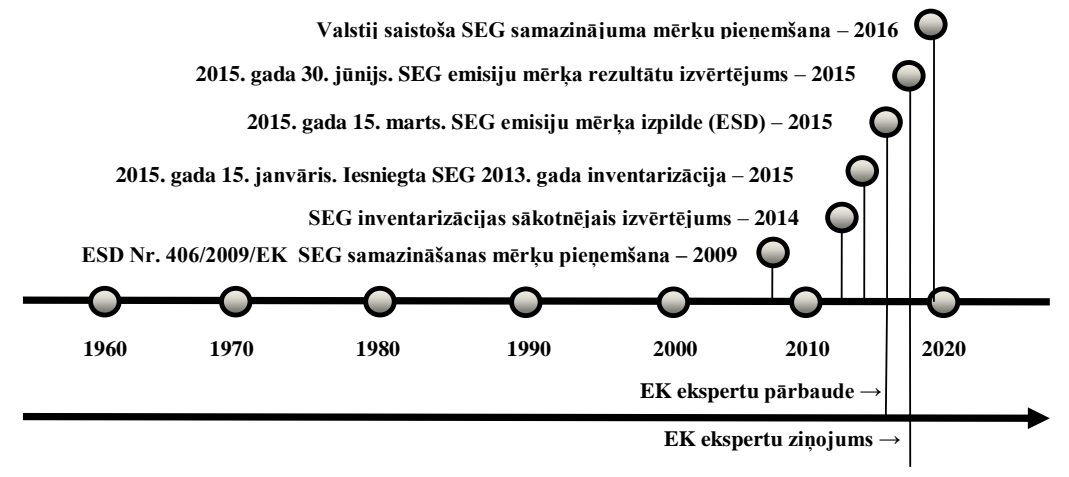

Avots: autora konstrukcija

6. att. SEG samazināšanas mērḳu pieṇemšanas galvenie posmi lauksaimniecībā.

Latvijā notiek aktīvs process SEG emisiju samazināšanas mērku noteikšanai lauksaimniecībā. SEG samazinājuma mērķu sasaiste ar lauksaimniecības attīstību, darba autora skatījumā, noteiks tālāko tās attīstības perspektīvu.

Latvijas LAP 2014. - 2020. gadam programmas izstrādes laikā tika ņemti vērā ES KLP reformu rezultātā noteiktie mērķi un prioritātes, kas 2014. 2020. gada plānošanas periodam tika izstrādāti vienoti visām ES dalībvalstīm, tādējādi iezīmējot jaunu pieeju, kas atškiras no iepriekšējās prakses, kad LAP prioritāšu noteikšana tika veikta individuāli katras valsts kontekstā. Izstrādājot Latvijas LAP 2014. - 2020. gadam, tika ņemta vērā tā saistība ar valsts un ES vides politikas plānošanas dokumentiem. 


\subsection{Institucionālā sistēma lauksaimnieciskas ietekmes uz vidi novērtēšanai}

Lai Latvija pilnvērtīgi pildītu savas starptautiskās saistības klimata pārmaiņu jomā, papildus SEG emisiju samazināšanai nepieciešams nodrošināt vairāku citu prasību izpildi: izveidot nacionālo sistēmu SEG emisijas un $\mathrm{CO}_{2}$ piesaistes aprēķiniem un ikgadējo pārskatu sagatavošanai, atbalstît zinātnisku pētījumu veikšanu klimata pārmaiņu jomā, kā arī informēt sabiedrību par jautājumiem, kas saistīti ar klimata pārmaiņām. Ne-ETS sektoru, kurā ietilpst lauksaimniecība, SEG emisiju samazināšanai mērķa izpildi koordinē Latvijas Republikas Vides un regionālās attīstības ministrija (VARAM). Klimata pārmaiņu samazinošas politikas izveidi un isstenošanu nodrošina un realizē Zemkopības ministrija (ZM), Ekonomikas ministrija (EM), Satiksmes ministrija (SM) un Finamšu ministrija (FM). VARAM ir vadošā valsts pārvaldes institūcija vides aizsardzības jomā, kas ietver ar̄̄ klimata pārmaiṇu novēršanu un pielāgošanos tai. Savukārt MK noteikumi Nr. 962 no 2004. gada 30. novembra (Vides dienesta,... 2004) reglamentē Valsts vides dienesta darbību un lauksaimniecības ietekmes uz vidi novērtējumu, realizējot likumā „Par piesārņojumu” noteiktos uzdevumus saistībā ar vidi piesārnojošu (SEG emisiju) atḷauju izsniegšanu piesārņojošās darbības veikšanai. Dienests kontrolē normatīvajos aktos par dabas resursu ieguvi un izmantošanu, dabas aizsardzību, piesārņojošo vielu emisiju vidē, bīstamo un sadzīves atkritumu apsaimniekošanu, izlietotā iepakojuma apsaimniekošanu, darbībām ar ķīmiskajām vielām un ķīmiskajiem produktiem noteikto prasību ievērošanu.

\section{Nacionālā sistēma SEG emisijas un $\mathrm{CO}_{2}$ piesaistes aprēḳiniem}

Saskaņā ar Konvencijas un Kioto protokola nosacījumiem, ikvienai Konvencijas līgumslēdzēju pusei ik gadu ANO Konvencijas sekretariātā jāiesniedz pārskats par antropogēnajām SEG emisijām un to piesaisti nacionālā inventarizācijas ziņojuma formā.

Ikgadējo inventarizāciju par SEG emisijām un piesaisti un nacionālo inventarizācijas ziņojumu gatavo Latvijas Vides, ǵeolog̣ijas un meteoroloğijas centrs (LVG̣MC), kas ir VARAM padotībā esoša institūcija. Latvijas Vides, ǵeoloǵijas un meteoroloǵijas centrs atbilstoši MK 2012. gada 27. marta noteikumiem Nr. 217 sagatavo SEG emisiju aprēķinus. Inventarizācija tiek gatavota, sadarbojoties ar CSP, EM, SM, ZM, kā arī šo ministriju pakḷautībā esošajām institūcijām. Lauksaimniecības SEG emisiju aprēkinināšanā ir iesaistîti eksperti no LLU. Savukārt inventarizācijas ziņojuma atbilstības novērtējumu veic pieaicinātie ārzemju eksperti no privātām organizācijām, uzṇēmumiem un atbilstošām zinātṇu nozarēm.

SEG emisiju ziņojumā ietvertie dati atspoguḷo rezultātu ar divu gadu nobīdi. Tāpēc svarīga un neatņemama ir klimata politikas un pasākumu dą̧a, kas vērsta uz SEG samazināšanas pasākumu nākotnes ietekmes novērtējumu un iespējamo $\mathrm{CO}_{2}$ piesaistes palielināšanu. Kvalitatīvi prognožu dati un plānoto un realizēto pasākumu ietekmes izvērtējums ir Kioto protokola progresa ziņojumu, nacionālo ziņojumu Konvencijas ietvaros, kā arī ES normatīvo aktu prasību 
izpildes pamatā. SEG emisiju un $\mathrm{CO}_{2}$ piesaistes prognožu aprēḳinos būtiska loma ir LLU.

Latvijā izstrādātie lauksaimniecību un dabas vides aizsardzību reglamentējošie tiesiski normatīvie akti un institucionālā vide atbilst starptautisko nolīgumu prasībām. Nākotnē ir nepieciešama aktīvāka LLU zinātnieku iesaiste SEG emisiju samazināšanas pasākumu izvērtēšanā, ṇemot vērā lauksaimniecības sektora straujo attīstību Latvijā.

\section{LAUKSAIMNIECISKO RAŽOŠANU RAKSTUROJOŠIE RĀDĪTĀJI UN TO IETEKME UZ DABAS VIDI LATVIJĀ}

Nodaḷas saturs darbā veidots no 24 lpp., kurās ietilpst 14 tabulas un 8 attēli.

Nodaḷā analizēti lauksaimniecības zemes izmantošanas, lauku saimniecību attīstības un SEG emisiju izmaiṇu rādītāji. Prognozēts SEG emisiju pieaugums lauksaimniecībā.

Nodal̦ā izvirzìtā tēze: Latvijas lauksaimniecība, it īpaši augkopība, dinamiski attīstās un veicina SEG emisiju veidošanos.

Latvijas dabas kapitāls ir tās teritorija, kuras pamats ir zeme. Saskan̄ā ar A. Dobeles (2005) izvirzīto definējumu, zeme ir teritorija, kas raksturojas ar noteiktām dabiskām īpaš̄̄bām - reljefiem, klimatiskajiem apstākḷiem, augsnēm, virszemes un dzīḷu bagātībām, kā arī konkrētu atrašanās vietu un izmantošanu".

Tātad jēdziens zeme ietver dažādas tās funkcijas un tās izmantošana ir jāvērtē vides, ekonomikas un sociālajās kategorijās. Izmantojot lauksaimniecību raksturojošos rādītājus ekonomiskajās un vides kategorijās, darba autors vērtē zemes kā resursa izmantošanas efektivitāti lauksaimniecībā. Darba autors secina, ka lauksaimniecības zemes izmantošanas efektivitāte Latvijā turpmāk būs atkarīga no šì resursa ilgtspējīga un funkcionāli atbilstoša izmantošanas veida. Šādā skatījumā lauksaimniecības zemes resursu izmantošanas efektivitāte Latvijā ir pētīta maz. Šajos pētījumos netiek veikts novērtējums tam, kā sasniegt mērḳi no ekonomiskā viedokḷa, izmantot visus pieejamos zemes resursus lauksaimniecībā, vienlaikus nodrošinot zemes resursu funkcionālu izmantošanu saistībā ar vides jautājumiem, piesārņojuma samazināšanu SEG emisiju veidā.

\subsection{Zemes izmantošanas raksturojums lauksaimniecībā}

Zemes izmantošanai ir jābūt racionālai, efektīvai un ilgtspējīgai. Ja zemi nav iespējams efektīvi izmantot lauksaimniecībā, tad ekonomikas attīstības nodrošināšanai tā jāizmanto mežsaimniecībā, apbūvē vai citiem mērḳiem, gūstot lielāku kopējo ekonomisko, vides un sociālo labumu iedzīvotājiem. 2015. gadā lauksaimniecība un mežsaimniecība izmantoja 88\% Latvijas zemes resursu un LIZ aizņēma aptuveni $36.4 \%$, bet meža zeme $-51.8 \%$ no valsts 
teritorijas. Pēc Valsts zemes dienesta (VZD) datiem novados kopā pa visām nekustamā īpašuma lietošanas mērķu grupām lauksaimniecībā izmantojamā zeme 01.01.2016. bija 2350.8 tūkst. ha un meža zeme 3347.1 tūkst ha.

Datu analīze parāda meža zemes platību palielināšanās tendenci. Lauksaimniecības zemes platības analizētajā laika periodā turpina samazināties un pēc statistikas datiem 2015. gadā tikai 1884.8 tūkst. ha tiek izmantoti lauksaimniecības produkcijas ražošanai. Nepilni $20 \%$ no pieejamā zemju resursa lauksaimniecībā netiek izmantoti, jo ir aizauguši vai nekopti. Zināmā mērā šāda situācija neveicina konkurenci, jo tā varētu būt pamats neefektīvas zemes izmantošanas problēmai Latvijā. Zemes politikas attīstības scenāriji paredz, ka tuvāko desmitu gadu laikā augs pieprasījums pēc lauksaimniecībā izmantojamās zemes, ko izsauks pieaugošais pieprasījums pēc pārtikas produktiem (Zemes politikas..., 2008).

Autora pētījumā zemes izmantošanas efektivitātes novērtējums un salīdzinājums saražotās produkcijas apjomiem un izlietotajiem resursiem tiek izvēlēts dinamikas laika rindu vērtībām no 1990. gada. Šis ir atskaites gads SEG emisiju inventarizācijas aprēķiniem. Savukārt zemes izmantošanas efektivitāte vides kategorijās tiks noteikta, aprēḳinot radīto emisiju apjomu uz izmantoto resursu vienību. Lauksaimniecības zemes resursu kvantitatīvo rādītāju izmaiņas Latvijā no 1990. gada līdz 2015. gadam pēc izmantošanas veida apkopotas 2 . tabulā.

2. tabula

Lauksaimniecības zemes izmantošanas veidi Latvijā 1990. - 2015. gadā,

tūkst. ha

\begin{tabular}{|c|c|c|c|c|c|c|c|c|c|c|c|}
\hline \multirow{2}{*}{ Gads } & \multirow{2}{*}{$\begin{array}{c}\text { LIZ } \\
\text { tūkst. } \\
\text { ha }\end{array}$} & \multicolumn{2}{|c|}{$\begin{array}{c}\text { Izmantota } \\
\text { LIZ }\end{array}$} & \multicolumn{2}{|c|}{ Aramzeme } & \multicolumn{2}{|c|}{$\begin{array}{l}\text { Ilggadīgie } \\
\text { stādījumi }\end{array}$} & \multicolumn{2}{|c|}{$\begin{array}{l}\text { Pḷavas, } \\
\text { ganības }\end{array}$} & \multicolumn{2}{|c|}{$\begin{array}{c}\text { Neizmantota } \\
\text { LIZ }\end{array}$} \\
\hline & & $\begin{array}{c}\text { tūkst. } \\
\text { ha }\end{array}$ & $\%$ & $\begin{array}{c}\text { tūkst. } \\
\text { ha }\end{array}$ & $\%$ & $\begin{array}{l}\text { tūkst. } \\
\text { ha }\end{array}$ & $\%$ & $\begin{array}{c}\text { tūkst. } \\
\text { ha }\end{array}$ & $\%$ & $\begin{array}{c}\text { tūkst. } \\
\text { ha }\end{array}$ & $\%$ \\
\hline 1990 & 2567.0 & 2534.0 & 98.7 & 1656.0 & 65.4 & 35.9 & 1.4 & 847.7 & 33.5 & 33 & 1.3 \\
\hline 1995 & 2501.3 & 1832.1 & 73.2 & 1002.3 & 54.7 & 19.3 & 1.1 & 800.5 & 43.6 & 669.2 & 26.8 \\
\hline 2000 & 2484.9 & 1587.2 & 63.9 & 969.9 & 61.1 & 11.5 & 0.5 & 605.7 & 38.2 & 897.7 & 36.1 \\
\hline 2005 & 2474.4 & 1733.7 & 70.0 & 1091.8 & 62.9 & 12.8 & 0.7 & 628.9 & 36.2 & 740.7 & 30.0 \\
\hline 2010 & 2430.0 & 1815.5 & 74.7 & 1173.4 & 64.6 & 6.8 & 0.4 & 625.2 & 34.4 & 614.5 & 25.3 \\
\hline 2015 & 2350.8 & 1884.8 & 80.2 & 1229.8 & 65.2 & 6.7 & 0.3 & 648.3 & 34.4 & 466.0 & 19.8 \\
\hline $\begin{array}{c}\text { Bāzes } \\
\text { izmaiņas, } \\
\% \\
\end{array}$ & -8.4 & -25.6 & -18.5 & -25.7 & -0.2 & -81.3 & $\mathrm{x}$ & -23.5 & +0.9 & +1312 & +18.5 \\
\hline
\end{tabular}

Avots: autora konstrukcija pēc CSP, 2015

LIZ izmantošanas kvantitatīvo rādītāju uzlabošanos ir veicinājuši objektīvi faktori:

$>$ kopš 2010. gada 13. jūlija ir spēkā LR MK noteikumi Nr. 635 „Kārtība, kādā apseko un nosaka neapstrādātās lauksaimniecībā izmantojamās zemes platību un sniedz informāciju par to" (Kārtība, kādā..., 2010);

$>$ no 2015. gada 10. marta LR MK noteikumos Nr. 126 „Tiešo maksājumu pieškiršanas kārtība lauksaimniekiem" ir veiktas izmainas atbalsta piešķiršanā par platībām lauksaimniecības zemju īpašniekiem no Eiropas 
Lauksaimniecības garantiju fonda. Ir noteikti ierobežojumi Vienotā platību maksājuma (VPM) saņemšanai par lauksaimniecībā izmantoto zemi, ja netiek izpildīti ar ražošanu saistītie nosacījumi par zemes izmantošanu (Tiešo maksājumu..., 2015).

LIZ platību palielināšanās nedrīkst būt par tās izmantošanas efektivitātes rādītāju. Lai novērtētu zemes izmantošanas efektivitāti, svarīgāki ir kvalitatīvie rādītāji. Lauksaimniecības platību palielināšana iezīmē lauksaimniecības attīstības ekstensīvo ceḷu, un šāda attīstība nozīmē izaugsmi uz ražošanas faktoru pieauguma rēḳina. Latvijas Lauksaimniecības universitātē (LLU) profesores I. Pilveres vadībā veiktajā pētījumā par LIZ efektīvas izmantošanas iespējām Latvijā ir noskaidrots, ka lauksaimniecības produkcija tiek ražota 1459 tūkst. ha (Pilvere I. u.c., 2014). Latvijā 2015. gadā VPM tika apstiprināti 1660 tūkst. ha LIZ. Lauksaimniecības attīstība dažādās Latvijas teritorijās ir atškirīga, un to var sadalīt: 1) intensīvās lauksaimniecības teritorijas, kas aptver valsts centrālo daļu un atsevišķus novadus arī no galvaspilsētas attālākajos regiionos un aizṇem aptuveni 900 tūkst. ha; 2) ekstensīvas lauksaimniecības teritorijas, kurās produkcija netiek ražota tirgum, bet pašpatēinnam un aizņem aptuveni 535 tūkst. ha (Saktiņa D., 2006).

Analizējot lauksaimniecību raksturojošos kvantitatīvos datus, ir konstatēti produkcijas ražošanas sektori, kuri veido būtiskāko daļu kopējā saražotās produkcijas vērtības struktūrā. Šie sektori ir galvenie ražošanas faktoru izmantotāji un ietekmes uz vidi veicinātāji. Latvijā 2015. gadā lauksaimniecības produkcijas vērtību bāzes cenās veido: graudi $33.1 \%$, piens $17.7 \%$, lopbarības kultūras/kukurūza $10 \%$, rapsis $8 \%$, cūkgaḷa $5.1 \%$, dārzeṇi $4.9 \%$, kartupeḷi $4.3 \%$, liellopu gaḷa $3.5 \%$, putnu gal̦a $3.5 \%$, olas $3.4 \%$, pārējie lopkopības produkti $3.2 \%$ un pārējie augkopības produkti $3.2 \%$ (Latvijas lauksaimniecība, 2016).

Izmantojot zemes resursus, Latvijā notiek lauksaimniecības attīstība, gan intensificējot ražošanu, gan attīstoties ekstensīvi. Graudkopība ir galvenais lauksaimniecības darbības sektors, kurā gan ražo pārtiku iedzīvotājiem, gan nodrošina ar lopbarību piena un gal̦as specializācijas saimniecības. Graudkopība, piena lopkopība, rapšu audzēšana un lopbarības kultūras/kukurūza kopā veido $70 \%$ no lauksimniecības gala produktu vērtības struktūras Latvijā 2015. gadā. Lai noskaidrotu, cik efektīvi attīstības procesā tiek izmantoti zemes resursi, 3.2. apakšnodaḷā autors analizēs lauksaimniecības zemes resursu izmantošanu saistībā ar vides rādītājiem, kas izteikti kā SEG emisijas $\mathrm{CO}_{2}$ eq vērtība.

\subsection{Lauku saimniecību raksturojums}

Latvijas lauksaimniecībā, un īpaši augkopībā, laika periodā no 2005. gada līdz 2015. gadam ir notikuši ekonomiskie procesi, kuri būtiski ietekmējuši ražošanas rezultatīvos rādītājus. Pēc autora domām, tieši ekonomisko procesu izmaiṇas lauksaimniecībā nosaka attīstības trajektoriju nākotnē. 
Zemes resursu izmantošanu Latvijas lauku saimniecībās ietekmē atšḳirīgi vides faktori reǵionos. Šo atškirīgo faktoru dẹl pastāv noteikta lauksaimnieciskās ražošanas regiionālā specializācija. Zemes resursu izmantošanas attīstība ir jāvērtē pēc zemes iespējami labākā funkcionālā pielietojuma (Schulte R., 2014). Darba autors pilnībā piekrīt šim viedoklim, tomēr uzskata, ka ekonomisko procesu virzīšanā līdztekus ekonomiskajām kategorijām papildus jāiekḷauj vides un sociālās kategorijas, lai lauksaimniecības attīstība būtu ilgtspējīga. Darba autors lauksaimniecības ekonomisko procesu attīstības analīzei Latvijā izmantos lauku saimniecību sadalījumu pēc to ekonomiskā lieluma, ko raksturo produkcijas standarta izlaide (SI) un specializācija. SI ir no viena lauksaimniecības hektāra vai lauksaimniecības dzīvnieku vienības iegūtās produkcijas vērtība, novērtēta attiecīgā regiiona cenās un izteikta EUR. Kopējā SI raksturo saimniecības ekonomisko lielumu naudas izteiksmē. Saimniecību ekonomiskā lieluma noteikšanai CSP izmanto Latvijas Valsts agrārās ekonomikas institūta (kopš 2016. gada - Agroresursu un ekonomikas institūta) aprēḳināto SI lauksaimniecības kultūru hektāram un lauksaimniecības dzīvnieku vienībai (CSP, 2016). Šāds sadalījums izvēlēts, lai noskaidrotu, kuras saimniecību grupas veido nozīmīgāko ietekmi ekonomiskajos procesos, kā arī atstāj lielāko iespaidu uz lauksaimniecības ilgtspèjīgu attīstību. Pēc lauku saimniecību apsekojuma datiem 2013. gada beigās Latvijā bija 81796 (CSP, 2016) lauku saimniecības. Lauku saimniecību raksturojošo rādītāju analīzes rezultātā darba autors secina, ka lauksaimniecības ilgtspējīgā attīstībā Latvijā lielākā ietekme ir laukkopības specializācijas saimniecībām, jo šo saimniecību produkcijas SI veido $37 \%$ no kopējās lauksaimniecības produkcijas izlaides.Pārējās nozīmīgākās saimniecību specializācijas grupas ir: piena lopkopība 28\%, jauktā augkopība un lopkopība 14\%, cūkkopība, putnkopība 13\% no kopējās SI.

Lauku saimniecību struktūras izmaiṇu aprēḳinu dati apkopoti 3. tabulā.

Lauku saimniecību struktūras izmaiṇas ekonomiskā lieluma grupās Latvijā 2005. - 2013. gadā, tūkst. EUR

\begin{tabular}{|c|c|c|c|c|c|c|c|c|}
\hline \multirow{2}{*}{ 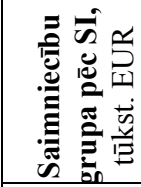 } & \multicolumn{2}{|c|}{2005} & \multicolumn{2}{|c|}{2010} & \multicolumn{2}{|c|}{2013} & \multicolumn{2}{|c|}{$\begin{array}{c}\Delta \text { bāzes } \\
\text { izmainas, \% }\end{array}$} \\
\hline & Skaits & $\begin{array}{c}\text { LIZ } \\
\text { tūkst. } \\
\text { ha }\end{array}$ & Skaits & $\begin{array}{c}\text { LIZ } \\
\text { tūkst. } \\
\text { ha }\end{array}$ & Skaits & $\begin{array}{c}\text { LIZ } \\
\text { tūkst. } \\
\text { ha }\end{array}$ & Skaits & LIZ \\
\hline Līdz 14.9 & 131237 & 1204.7 & 76277 & 774.9 & 73603 & 683 & -44 & -43 \\
\hline $15.0-99.9$ & 1521 & 289.6 & 6002 & 441.5 & 6754 & 471.4 & 344 & 63 \\
\hline virs 100 & 247 & 210.9 & 1107 & 580 & 1439 & 723.3 & 483 & 129 \\
\hline Kopā & 133005 & 1705.2 & 83386 & 1796.3 & 81796 & 1877.7 & -39 & 10 \\
\hline
\end{tabular}

Avots: autora konstrukcija pēc CSP, 2016

Kopējais lauku saimniecību skaits Latvijā 2013. gadā salīdzinājumā ar 2005. gadu ir samazinājies par 39\%. Lauku saimniecību strukturālās izmaiņas 
būtiski ir ietekmējušas ekonomiski mazās saimniecības, kuru skaits ir samazinājies strauji, - par 44\%. Pieaudzis to saimniecību skaits, kuru lauksaimnieciskās produkcijas SI pārsniedz 100 tūkst. EUR, un 2013. gada beigās Latvijā bija 1439 šādas saimniecības jeb 5.8 reizes vairāk, nekā 2005 . gadā. Latvijā pēc 2005. gada lauksaimniecībā norisinās līdzīgi ekonomiskie procesi kā pārējā ES un pasaulē. Mazo lauku saimniecību attīstībai ir lielākais apdraudējums, jo skaidri iezīmējas ekonomiskā modeḷa - lauksaimniecība kā bizness - attīstība.

\subsection{Lauksaimnieciskā ražošana un tās radītās SEG emisijas}

Lai būtu iespējams uzraudzīt izvirzītos mērḳus SEG emisiju samazināšanai ES un veikt to korekciju, ir nepieciešama atbilstoša indikatīvo rādītāju aprēķināšanas un uzkrāšanas sistēma, kuru Latvijā veic atbilstoši 2012. gada 27. martā pieņemtajiem MK noteikumiem Nr.217 (Noteikumi par siltumnīcefekta..., 2012). Klimata izmaiṇu mazināšanas mērḳis, kuru apṇēmās sasniegt ES dalībvalstis (Decision No 406/2009), paredz SEG emisiju samazinājumu 2020. gadā par 20\% salīdzinājumā ar 1990. gadu.

Lauksaimniecība ir iekḷuta starp SEG emisiju avotiem, kur nepastāv kvotu tirdzniecības sistēma (ne-ETS). Tomēr, lai sasniegtu stratēgijas Eiropa 2020 mērḳus SEG emisiju samazinājumam transportā, mājsaimniecībās, lauksaimniecībā un atkritumu apsaimniekošanā, katrai valstij ir jāaprēķina un jāiesniedz ANO valsts inventarizācijas ziņojumi. Dokumentā apkopotā informācija ir: 1) valsts SEG emisiju inventarizācijas ziņojums NIR (Latvian's National..., 2015); 2) valsts SEG emisiju inventarizācijas skaitliskie dati, sakārtoti atbilstoši standartizētam ziṇojuma formātam (Common Reporting Format, 2015). Saistībā ar zemes izmantošanu, zemes izmantošanas maiņu un mežsaimniecības sektoru tiek veidots atsevišķs ziņojums SEG emisiju inventarizācijai, kas šajā darbā netiek analizēts (Land Use, Land Use Change and Forestry, 2015).

Atbilstoši Kioto protokolam Latvijai no 2008. līdz 2012. gadam bija jāpanāk SEG emisiju samazinājums par 8\%, salīdzinot ar SEG emisiju apjomu 1990. gadā. Šo uzdevumu Latvija sekmīgi paveica.

Pēc aprēķinātajiem un NIR iesniegtajiem rezultātiem, lauksaimniecība 2013. gadā radīja $2310 \mathrm{Gg} \mathrm{CO}_{2}$ eq SEG emisiju, kas bija otrs lielākais emisiju avots Latvijā, veidojot $22 \%$ no kopējām ne-ETS emisijām. 1990. gadā

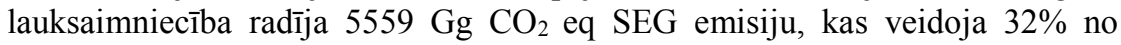
kopējām ne-ETS emisijām, un prognožu rezultāti par ekonomikas attīstību Latvijā apstiprina, ka līdz 2030. gadam lauksaimniecības SEG emisijas pieaugs, sasniedzot 33\% no kopējām ne-ETS SEG emisijām, tomēr nesasniedzot 1990. gada rādītāju (SEG aț̣autās emisijas, 2014). Autoraprāt, šāda lauksaimniecības nozares radīto SEG emisiju dinamika Latvijā liecina, ka bez papildu ierobežojošiem pasākumiem Latvija neizpildīs starptautiski noteiktos SEG emisiju samazināšanas mērķus. 
Pēc Latvijas NIR inventarizācijas ziņojumā apkopotajiem rādītājiem, pielietojot datu analīzes statistiskās apstrādes metodes, darba autors aprēķināja, kuras no antropogēnajām gāzēm $\left(\mathrm{N}_{2} \mathrm{O}, \mathrm{CH}_{4}\right.$ un $\left.\mathrm{CO}_{2}\right)$ ir veicinājušas SEG emisiju pieaugumu lauksaimniecībā. Visu klimata izmaiņas veicinošo SEG emisiju veidi lauksaimniecībā Latvijā 2013. gadā, salīdzinot ar bāzes gadu, ir samazinājušies: $\mathrm{N}_{2} \mathrm{O}$ par $46 \%, \mathrm{CH}_{4}$ par $66 \%$ un $\mathrm{CO}_{2}$ par $95 \%$, bet, sākot ar 2005. gadu, palielinājušies, kas saistīts ar 3.1. nodaḷā aprakstīto un skaidroto lauksaimniecības izaugsmi. Lielākais pieaugums ir konstatēts $\mathrm{N}_{2} \mathrm{O}$ 2013. gadā, kad emisijas pieauga par 18\% salīdzinājumā ar 2005. gadu.

Rādītāju laika rindu analīzes rezultāti apkopoti 4. tabulā.

4. tabula

Lauksaimniecības SEG emisiju veidi Latvijā 1990. - 2013. gadā,

$\mathrm{Gg} \mathrm{CO}_{2}$ eq

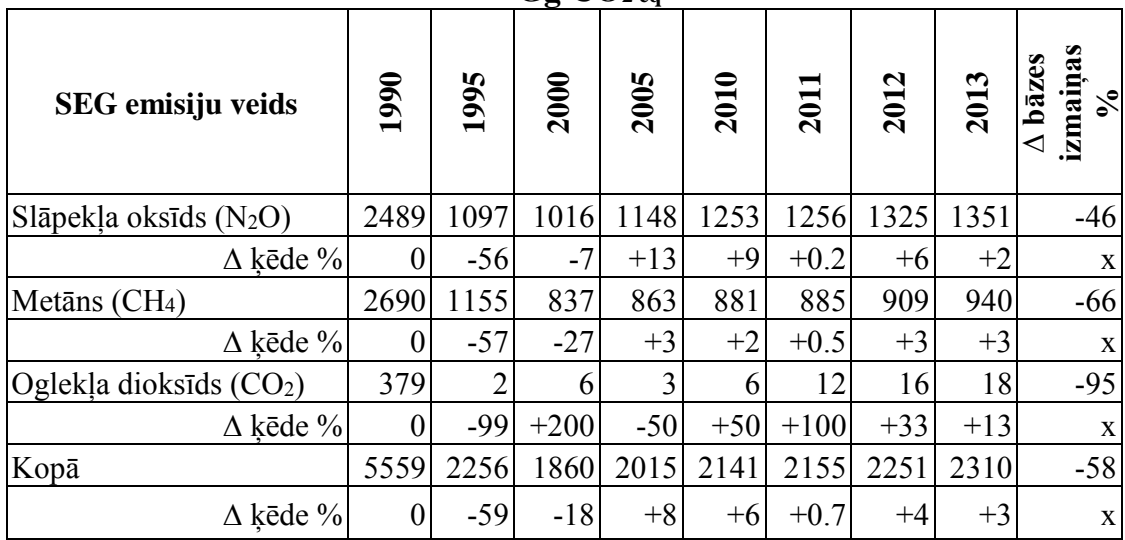

Avots: autora konstrukcija pēc NIR, 2015

Tā kā lielāko īpatsvaru Latvijas lauksaimniecības SEG emisiju struktūrā veido lauksaimniecības augšnu izmantošana, tad darba turpmākajā gaitā un noteiktā pētījuma mērķa sasniegšanai ir nepieciešams noskaidrot, kuri faktori veicina SEG emisijas no šī emisiju avota. Galvenie $\mathrm{N}_{2} \mathrm{O}$ tiešo emisiju avoti ir: 1) mākslīgie slāpekḷa minerālmēsli ( $\mathrm{N}$ tīrviela); 2) organiskais $\mathrm{N}$ mēslojums (piemēram, kūtsmēsli, komposts, notekūdeņu dūņas); 3) uz lauka ganībās vai aplokos izdalītais N no dzīvnieku mēsliem; 4) augu atlieku uzkrātais un iestrādātais N uz lauka (zaļmēslojums, augu atliekas u.c.); 5) izmantotās meliorētās organiskās augsnes (kūdrāji).

Tiešās $\mathrm{N}_{2} \mathrm{O}$ emisijas no izmantotajām organiskajām augsnēm ir $54 \%$, un tiešās $\mathrm{N}_{2} \mathrm{O}$ emisijas no izmantotajiem $\mathrm{N}$ minerālmēsliem ir $23 \%$ no kopējās LIZ izmantošanas. $\mathrm{N}$ izmantošana ir būtiska, lai nodrošinātu augkopības produkcijas ražošanu. Taču, tiešās $\mathrm{N}_{2} \mathrm{O}$ emisijas no $\mathrm{N}$ minerālmēslu izmantošanas laika posmā no 2005. gada līdz 2013. gadam ir pieaugušas par $83 \%$, sasniedzot $326.7 \mathrm{Gg} \mathrm{CO}_{2 \text { eq }}$ gadā.

Rādìtāji un to analīzes rezultāti apkopoti 5. tabulā. 
5. tabula

Lauksaimniecības augšṇu $\mathrm{N}_{2} \mathrm{O}$ emisiju faktoru sadalījums un izmaiṇu dinamika Latvijā 1990. - 2013. gadā, Gg

\begin{tabular}{|c|c|c|c|c|c|c|c|}
\hline \multirow[b]{2}{*}{ Emisiju faktors } & \multicolumn{6}{|c|}{ Gads } & \multirow{2}{*}{ 胥 } \\
\hline & જ̆ & ஜू & ఠ్రి & 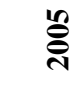 & $\stackrel{\ominus}{\overline{\mathcal{N}}}$ & $\stackrel{m}{\vec{\sigma}}$ & \\
\hline Organiskās augsnes & 2.6 & 2.6 & 2.5 & 2.5 & 2.5 & 2.6 & 0 \\
\hline$\Delta$ ķēde, $\%$ & 0 & 0 & -4 & 0 & 0 & +4 & $\mathrm{x}$ \\
\hline $\begin{array}{l}\text { Minerālmēslu } \\
\text { lietošana }\end{array}$ & 2.1 & 0.2 & 0.4 & 0.6 & 0.9 & 1.1 & -47 \\
\hline$\Delta$ ķēde, $\%$ & 0 & -90 & +100 & +50 & +50 & +22 & $\mathrm{x}$ \\
\hline $\begin{array}{l}\text { Organiska mēslojuma } \\
\text { lietošana }\end{array}$ & 0.8 & 0.4 & 0.3 & 0.3 & 0.3 & 0.3 & -63 \\
\hline$\Delta$ ķēde, $\%$ & 0 & -50 & -25 & 0 & 0 & 0 & $\mathrm{x}$ \\
\hline Kūtsmēsli ganībās & 0.5 & 0.2 & 0.1 & 0.1 & 0.1 & 0.2 & -60 \\
\hline$\Delta$ kiēde, $\%$ & 0 & -60 & -50 & 0 & 0 & +100 & $\mathrm{x}$ \\
\hline $\begin{array}{l}\text { Augu atliekas } \mathrm{uz} \\
\text { lauka }\end{array}$ & 0.6 & 0.3 & 0.3 & 0.4 & 0.4 & 0.6 & 0 \\
\hline$\Delta$ ķēde, $\%$ & 0 & -50 & 0 & +33 & 0 & +50 & $\mathrm{x}$ \\
\hline
\end{tabular}

Avots: autora konstrukcija pēc NIR, 2015

Regresijas analīze ir pamats darba autora secinājumam, ka dz̄ivnieku skaita izmain̄ām, produkcijas izlaidei un SEG emisiju pieaugumam lauksaimniecībā nav novērojama cieša sakarība, jo $\mathrm{R}^{2}$ vērtība ir būtiski mazāka par 0.8 , kas norāda, ka nav konstatējama cieša faktoru mijiedarbība. Lauku saimniecības, attīstot lopkopību, ievēro kūtsmēslu apsaimniekošanas normatīvo regulējumu. Atbilstošu prasību ieviešana saimniekošanas sistēmā nodrošina dabas videi nekaitīgu izaugsmes iespējamību, samazinot SEG emisijas.

Analizējot statistikas datus par lauksaimniecības ražošanas attīstību un tās radīto ietekmi uz vidi SEG emisiju veidā, darba autors izvirza secinājumu, ka lielāko ietekmi veido augkopības produkcijas ražošana.

Iegūtie aprēḳinu rezultāti l̦auj secināt, ka lauksaimniecībā resursu izmantošana nav efektîva. Tam par iemeslu, pēc autora domām, ir zemes kā resursa neefektīva izmantošana. Attīstībai ir jāizvēlas ilgtspējīgas intensifikācijas ceḷš, atsaistot izmantoto ražošanas faktoru pieaugumu no saražotās produkcijas apjomu pieauguma.

\subsection{Lauksaimniecības SEG emisiju pieauguma prognoze Latvijā līdz 2020. gadam}

Latvijā SEG emisijas lauksaimniecībā no 2005. gada līdz 2015. gadam ir palielinājušās par $20 \%$, un tas ir otrs augstākais rādītājs Eiropas valstīs aiz Igaunijas. Saskaņā ar LLU veikto detalizēto pētījumu par lauksaimniecības zemes izmantošanu, ekonomiski pamatota ir papildu 275 tūkst. ha LIZ iesaistīšana lauksaimnieciskajā ražošanā (Pilvere I. u.c., 2014). Tāpēc papildu 
LIZ iesaistīšana lauksaimnieciskās produkcijas ražošanai palielinās emisiju apjomu no lauksaimniecības. Situācija būtiski mainīsies pēc 2020. gada, jo saskan̄ā ar jauno Latvijas indikatīvo mērki līdz 2030. gadam ir jāpanāk SEG emisiju samazinājums ne-ETS sektoros salīdzinājumā ar 2005. gada līmeni par 6\% (Par mehānismu..., 2013), kas pēc autora domām ir liels izaicinājums, vērtējot līdzšinējos rezultātus. Būtībā no 2020. gada līdz 2030. gadam piel̦aujamais emisiju pieaugums par $17 \%$ ne-ETS sektoros nebūs piel̦aujams, un jau šobrīd jāplāno SEG emisiju samazinājums arī lauksaimniecībā. Darba iepriekšējās nodaḷās tika secināts, ka augkopības nozares attīstība notiek, intensificējot LIZ izmantošanu, īpaši graudu audzēšanā. Balstoties uz pieņēmumu, ka līdz šim neizmantotie 275 tūkst. ha LIZ tiks izmantoti augkopībā, turpinājumā tiks aprēķinātas tiešās $\mathrm{N}_{2} \mathrm{O}$ emisijas, ko veidos papildu $\mathrm{N}$ mēslojuma izmantošana, augu atliekas un citi emisiju avoti.

Lai aprēḳinātu SEG emisiju pieaugumu, autors darbā izmanto IPCC aprēḳinu metodiku. Saskaņā ar IPCC vadlīnijām ir iespējami trīs aprēḳinu līmeņi ar pieaugošu sarežğîtīibas pakāpi. Tā kā Latvijā ir veikti salīdzinoši maz zinātnisku pētījumu par SEG emisijām no lauksaimnieciskās ražošanas, tad ir jāizmanto pirmā līmeņa aprēḳinu metodika (Tier 1). Metodolog̣ija paredz izmantot viegli pieejamus statistikas datus un izmantot zinātniski pamatotus, bet vispārinātus emisiju faktorus. Atsevišķiem SEG emisiju veidiem lopkopībā Latvijā tiek izmantota otrā līmeṇa (Tier 2) aprēḳinu metodika, jo ir zinātniski pamatotas regiionālās emisijas faktoru atšķirības (Latvian's National, 2015).

$\mathrm{N}_{2} \mathrm{O}$ tiešās emisijas no lauksaimniecībā izmantotās augsnes aprēḳina pēc 1. formulas.

$$
\mathrm{N}_{2} \mathrm{O}_{\mathrm{SN} \text { Direct }}-\mathrm{N}=\left[\mathrm{N}_{2} \mathrm{O}-\mathrm{N}_{\mathrm{N} \text { inputs }}\right]=\left[\left(\mathrm{F}_{\mathrm{SN}}+\mathrm{F}_{\mathrm{AM}}+\mathrm{F}_{\mathrm{BN}}+\mathrm{F}_{\mathrm{CR}}\right) * \mathrm{EF}_{1}\right]+\left(\mathrm{F}_{\mathrm{OS}} * \mathrm{EF}_{2}\right) \text {, (1.) }
$$

kur: $\mathrm{N}_{2} \mathrm{O}_{\text {SN Direct }}-\mathrm{N}$ - tiešās emisijas no augkopībā izmantotajiem $\mathrm{N}$ minerālmēsliem $\mathrm{kg} \mathrm{N}_{2} \mathrm{O}-\mathrm{N}$ gadā $^{-1}$,

FSN - augkopībā izmantotie N minerālmēsli (tīrviela) kg gadā,

$\mathrm{F}_{\mathrm{AM}}$ - ikgadējais ar dzīvnieku kūtsmēsliem uznestais slāpekḷa oksīda ekvivalents,

FBN - slāpekḷa apjoms, ko piesaistījuši slāpekli fiksējošie augi,

$\mathrm{F}_{\mathrm{CR}}$ - slāpekḷa apjoms, ko satur uz lauka paliekošās augu atliekas,

FOS - slāpeklis no kultivētajām organiskajām augsnēm,

$\mathrm{EF}_{1}-\mathrm{N}_{2} \mathrm{O}$ emisiju faktors izmantotajiem $\mathrm{N}$ minerālmēsliem, $\mathrm{kg} \mathrm{N}_{2} \mathrm{O}-\mathrm{N}\left(\mathrm{kg} \mathrm{N}_{\text {izm}}\right)^{-1}$,

$\mathrm{EF}_{2}$ - emisiju faktors SEG emisijai no kultivētajām organiskajām augsnēm $\mathrm{kg} \mathrm{N}_{2} \mathrm{O}-\mathrm{N}(\mathrm{kg} \mathrm{N} \text { izm })^{-1}$.

Aprēkināāta $\mathrm{N}_{2} \mathrm{O}-\mathrm{N}$ emisija no izmantotajiem $\mathrm{N}$ minerālmēsliem saskaṇā ar noteiktajām 2006. gada IPCC vadlīnijām ir jāpārrēḳina $\mathrm{N}_{2} \mathrm{O}$ emisijā, izmantojot 2. sakarību.

$$
\mathrm{N}_{2} \mathrm{O}=\mathrm{N}_{2} \mathrm{O}-\mathrm{N} * 44 / 28
$$

Mainīgās augkopības SEG emisiju daḷas sadalījums augkopības kultūraugu grupās ir aprēkinināts, balstoties uz slāpekḷa minerālmēslu patēriņu.

Aprēkinini ir veikti: 
1) izmantojot datus par augkopības kultūraugu kopražu un $N$ minerālmēslu patēriņu. Proporcionāli kopražu atšķirībām ir aprēķināts aptuvenais slāpekḷa minerālmēslu patēriņš 2012. gadā un prognozētais 2020. gadā;

2) pēc N minerālmēslu sadalījuma augkopības kultūraugu grupās, proporcionāli ir aprēķināts SEG emisiju no augsnēm main̄̄gās daḷas sadalījums pa augkopības kultūraugu grupām.

No 275 tūkst. ha papildus iesaistîtām platībām varētu iegūt no 12\% (graudi, rapši) līdz pat $17 \%$ (kartupel̦i, plavu/ganību zaḷā masa) papildu produkciju no attiecīgā kultūrauga kopražas salīdzinājumā ar 2012. gadu (Pilvere I., 2014). Proporcionāli ražošanā papildus iesaistītajām LIZ platībām atbilstoši tika aprēķināts nepieciešamais minerālmēslu daudzums un katras augkopības kultūras papildus radītās SEG emisijas. Rezultāti apkopoti 6. tabulā.

\section{Augkopības kopražas potenciāla un SEG emisiju prognozes Latvijā}

6. tabula

2020. gadā

\begin{tabular}{|c|c|c|c|c|c|c|c|c|}
\hline \multirow[b]{2}{*}{ Kultūra } & \multirow{2}{*}{ 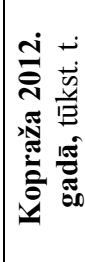 } & \multirow{2}{*}{ 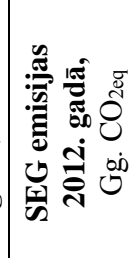 } & \multicolumn{3}{|c|}{ Papildus LIZ } & \multirow{2}{*}{ 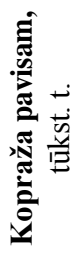 } & \multirow{2}{*}{ 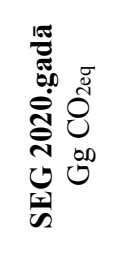 } & \multirow{2}{*}{ 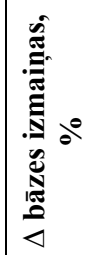 } \\
\hline & & & $\begin{array}{l}\text { g } \\
\dot{\vec{n}} \\
\text { 音 }\end{array}$ & 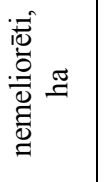 & 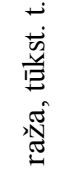 & & & \\
\hline Graud & 2124 & 737.56 & 87197 & 16394 & 334 & 2799 & 971.88 & +32 \\
\hline Rapši & 303 & 212.24 & 17399 & 3268 & 46 & 373 & 260.84 & +23 \\
\hline Kartupeḷi & 538 & 11.59 & 6276 & 1014 & 146 & 881 & 18.95 & +6 \\
\hline Kukurūza & 553 & 42.46 & 3769 & 563 & 131 & 849 & 65.11 & +5 \\
\hline $\begin{array}{l}\text { Zaḷbarības/ } \\
\text { skābbarības kultūras }\end{array}$ & 721 & 12.86 & 61756 & 11718 & 1292 & 898 & 68.65 & +53 \\
\hline Pḷavas, ganības & 167 & 1.34 & 98820 & 19098 & 833 & 478 & 36.66 & +2700 \\
\hline Dārzeņi & 161 & 4.77 & 0 & 0 & 0 & 195 & 5.76 & +120 \\
\hline Kopā & $\mathbf{x}$ & 1022.83 & 275217 & 52055 & $\mathbf{x}$ & $\mathbf{x}$ & 1427.85 & +39 \\
\hline
\end{tabular}

Avots: autora konstrukcija pēc Pilvere I. u. c., 2014

SEG emisiju main̄̄gās daḷas pieaugums, ja papildu lauksaimnieciskajā ražošanā iesaistīs 275 tūkst. ha, augkopībā 2020. gadā būs par 39\% vairāk salīdzinājumā ar 2012. gada līmeni. Pieaugums salīdzinājumā ar pētîjuma bāzes - 2005. gadu var sasniegt pat $80 \%$, ja augkopības attīstība būs intensīva.

D. Dogertijs (1996) tehnologiju attīstības un inovāciju saistību ir formulējis kā procesu vadību, jo: ,...inovācija nozīmē radīt jaunu koncepciju par produktu vai pakalpojumu, tā attīstību, ražošanu un realizāciju, vienlaicīgi nodrošinot nepārtrauktu procesa pārvaldību”, kas nozīmē lauksaimniecībā precīzu sasniedzamo mērḳu noteikšanu un novērtējuma sistēmas izveidošanu mērḳa sasniegšanas kontrolei SEG emisiju samazināšanā. 


\section{AUGKOPĪBAS ILGTSPĒJĪGA INTENSIFIKĀCIJA LAUKSAIMNIECĪBAS ATTĪSTĪBAI LATVIJĀ}

Nodalıas saturs darbā veidots no 24 lpp., kurās ietilpst 6 tabulas un 11 attēli. Nodaḷā izstrādāta augkopības ilgtspējīgas intensifikācijas novērtējuma metodologija. Veikts attīstības novērtējums Latvijā.

Nodaḷa izvirzītā tēze: Augkopības ilgtspējīga intensifikācija samazina negatīvo ietekmi uz vidi, nodrošinot lìdzsvarotu ekonomiskās, sociālās un dabas vides attīstību.

Darba autors uzskata, ka I. Kauliṇa (2015) promocijas darbā izstrādātā teritorijas ilgtspējīgas attīstības novērtēšanas metode ir izmantojama arī lauksaimniecībā. Pēc autora domām, ilgtspējīga attīstība un tās novērtěšana Latvijas tautsaimniecībā ir pētīta salīdzinoši daudz, tomēr lauksaimniecības ražošanas attīstības ietekme uz lauku vidi ilgtspējas kontekstā ir pētīta nepietiekami. Pēc nodalāa „Lauksaimniecības ilgtspējīgas attīstības teorētiskie aspekti" veiktās analīzes un darba otrajā nodạ̧ā novērtētās normatīvo aktu sistēmas darba autors secināja, ka, novērtējot lauksaimniecības attīstību, nākotnē ir jāizmanto rādītāji, kas raksturo attīstību ekonomiskajās, vides un sociālajās kategorijās vienlaicīgi. Šādu att̄̄stības novērtēšanu veic, izmantojot kompleksu rādītāju kopumu, aprēķinot attīstību raksturojošos indikatorus pēc atbilstošas metodologijas.

Uzticamas lauksaimniecības ilgtspējīgas attīstības rādītāju sistēmas izveidošana ir nepieciešama lauksaimniecības produkcijas ražotājiem, iedzīvotājiem un arī politikas veidotājiem.

\subsection{Ilgtspējīgas intensifikācijas novērtēšana}

2016. gada 1. jūlijā Latvija kḷuva par ESAO 35. dalībvalsti. Kā iestāšanās likumsakarīgs priekšnoteikums bija izstrādāt atbilstošu lauksaimnieciskās ražošanas ilgtspējīgas attīstības novērtējuma modeli.

ES ilgtspējīgas attīstības novērtējums tiek veikts 10 attīstîbas mērkikiem, izmantojot 11 kombinētos rādītājus (Eurostat, 2015). ES galvenie mērḳi ilgtspējīgai lauksaimniecības attīstībai ir: ražot drošu un veselīgu pārtiku; saglabāt dabas resursus; nodrošināt lauku saimniecību ekonomisko dzīvotspēju; uzlabot ekosistēmu pakalpojumu sniegšanu; attīstīt lauku vides pārvaldību; uzlabot dzīves kvalitāti lauku apvidos; nodrošināt lauksaimniecības dzīvnieku labturību. Visplašāk indikatoru sistēmas ir izstrādātas un izmantotas ESAO (OECD) valstu attīstības novērtēšanai.

Latvijā ilgtspējīgas attīstības mērḳu sasniegšanai un rezultatīvo rādīiāju novērtēšanai ir izstrādāta Latvijas ilgtspējīgas attīstības stratēgija līdz 2030. gadam, un noteikti attīstību raksturojošie rādītāji jeb indikatori, kuri ir sadalīiti septiṇos mērḳa attīstības virzienos, izceḷot stratēgiski svarīgākos rādītājus. Lauksaimniecības ilgtspējīgas attīstības novērtēšanai izmantojami rādītāji, kas raksturo mērḳu „Inovatîva un ekoefektīva ekonomika” un „Daba 
kā kapitāls nākotnei” sasniegšanu. Tomēr, pēc autora domām, šo rādītāju izmantošana tiešā veidā lauksaimniecības ilgtspējīgas intensifikācijas novērtēšanai nav iespējama, jo satur pretrunas. Lai novērtētu dabas kapitāla ilgtspējīgu izmantošanu, tiek izmantots rādītājs - SEG emisijas, kura vērtībai 2030. gadā ir jābūt mazākai nekā bāzes gadā. Savukārt NAP indikatoram Lauksaimniecības zemju apsaimniekošana ir norādīts pieaugums pret bāzes gadu (Pārresoru koordinācijas, 2015). Izvirzot mērḳi panākt ilgtspējīgu augkopības intensifikāciju lauksaimniecībā, ir jānovērtē attīstības radītās izmaiņas ekonomiskajās, vides, sociālajās un tehnologiskajās kategorijās lauku vidē. Attīstība jāveido sinerğijā, lai varētu sasniegt izvirzītos ilgtspējī̄gas attīstības mērķus. Valsts makroekonomikas līmenī lauksaimniecības ilgtspējīgas intensifikācijas attīstības novērtēšanai ir jāizmanto kombinēts, sintētisks rādītājs jeb indikators, kurš vislabāk raksturotu katra ražošanā izmantotā kapitāla izmaiņas. Šajā pētījumā augkopības ilgtspējīgas intensifikācijas novērtēšanu autors veic, izmantojot četru soḷu metodiku, kuru veido: (1) darbības cēloṇu identifikācija un definēšana; (2) atbilstošu ilgtspējības rādītāju definēšana; (3) ilgtspējīgas intensifikācijas indeksu noteikšana; (4) ietekmes uz ilgtspējīgu attīstību novērtěšana. Atbilstoši lauksaimniecības ilgtspējīgas intensifikācijas definīcijai darba autors pētīs, kādai ir jābūt katra kapitāla formu raksturojoša rādītāja izmaiņu dinamikai. Ilgtspējīgas intensifikācijas novērtējums, kas parāda sakarības starp cilvēku labklājības pieaugumu, izlietoto resursu daudzumu un ietekmes uz vidi samazinājumu, redzams 7. attēlā.

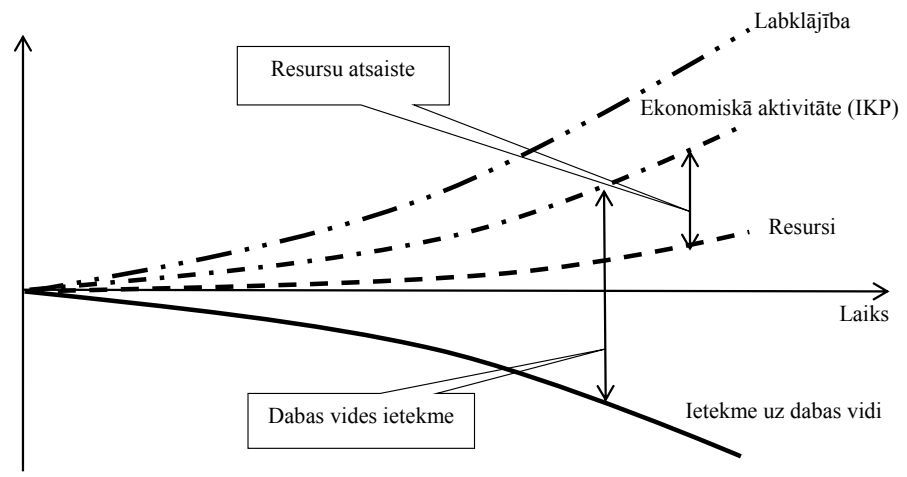

Avots: autora konstrukcija pēc UNEP, 2011

\section{7. att. Lauksaimniecības ilgtspējīgas intensifikācijas novērtējuma grafiskais atspoguḷojums.}

Kapitāla vērtību izmaiņas raksturojošajiem rādītājiem ir jābūt: atbilstošiem, uzticamiem, precīziem, salīdzināmiem, viegli interpretējamiem un labas kvalitātes/ticamiem pamata datiem.

Indikatoru aprēkināšanai tiek izmantoti lauku saimniecību aktivitātes dati, kuri raksturo hierarhijas zemāko līmeni dabas vides, ekonomiskās vides un sociālās vides kategorijās. Izvēloties raksturojošo rādītāju, ir iespējams 
izmantot: tiešos datus (piemēram, SEG emisijas augkopībā); attiecību vai koeficientu (piemēram, SEG emisijas augkopībā no kopējām lauksaimniecības emisijām); relatīvo rādītāju (piemēram, SEG emisijas uz bruto pievienoto vērtību augkopībā).

Rādītāju atlases un aprēḳināšanas gaita, kas attiecas uz SEG emisijām dabas vidē, apkopota 8 . attēlā.

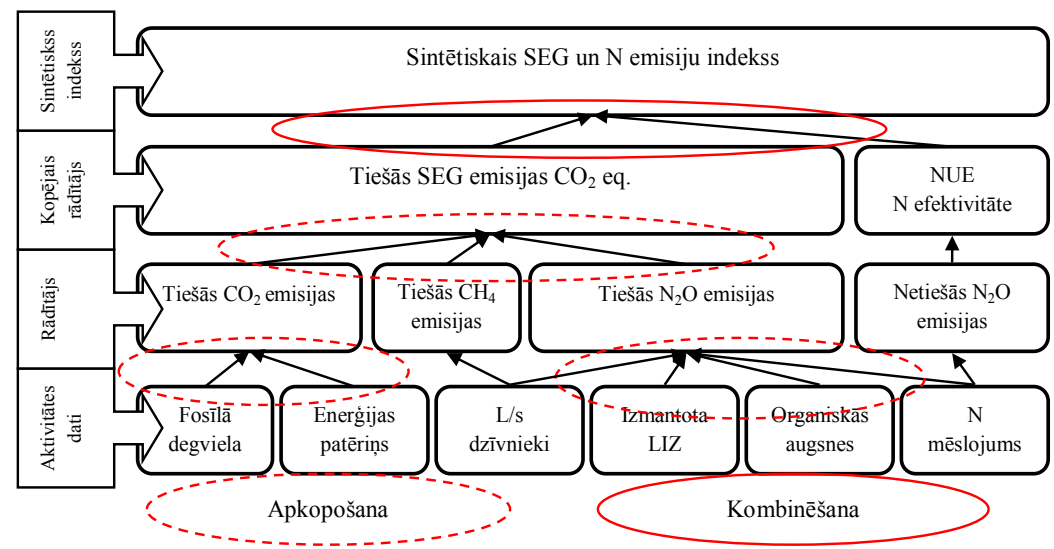

Avots: autora konstrukcija

\section{8. att. Lauksaimniecības ilgtspējīgu intensifikāciju raksturojošo rādītāju apkopošanas secība dabas vides novērtēšanai.}

Izmantojot autora izveidoto rādītāju atlases un aprēḳināšanas metodiku, tiek atlasīti rādītāji, kuri visprecīzāk raksturo izmaiņas dabas, ekonomiskajā un sociālajā vidē, kā arī atspoguḷo galvenās darbību cēloṇsakarības augkopībā, kurām ir ietekme uz ilgtspējīgu intensifikāciju.

Galvenās rādītāju grupas ir:

> ekonomiskā vide - rentabilitāte, saimnieciskas darbības diversifikācija, finanšu un resursu autonomija, saimnieciskās darbības stabilitāte;

> sociālā vide - darba un sadzīves apstākḷi lauku saimniecībā, labas saimniekošanas prakses izmantošana, sociāli atbildīga produkcijas ražošana;

$>$ dabas vide - izmantotie mēslošanas un augu aizsardzības līdzekḷi, lauksaimniecības zemes apstrāde, atjaunojamie energo resursi, lauksaimniecības zemes kvalitātes kontrole, biolog̣iskā daudzveidība, SEG emisijas;

$>$ tehnoloǵijas/inovācijas - tehnoloǵisko procesu un iekārtu nomaiṇa, produktu attīstība, zināšanu apguve.

Lauksaimniecības intensifikācijas apstākḷos svarīgi ir noteikt ilgtspēju saimniecību līmenī. Lauksaimniecības produktus ražojošās lauku saimniecības ir l̦oti atšḳirīgas pēc to ekonomiskā lieluma un ražošanas specializācijas virziena. Izmantojot aprēḳinātos ilgtspējīgas intensifikācijas indeksus, ir 
iespējams salīdzināt dažādo lauku saimniecību sociālās, ekonomiskās, vides un arī tehnolog̣isko/inovāciju ilgtspējas rādītājus.

\subsection{Ilgtspējīgas lauksaimniecības veidošanas piemēri}

Augkopības izaugsmi un pārstrukturēšanos tieši ietekmē ES stratēgiijā 2020. Lauku saimniecību strukturālās izmaiņas ir ietekmējusi lauksaimniecības iesaistī̌šnās atjaunojamo bioresursu ražošanā un bioekonomikas principos balstītā tautsaimniecības modeḷa veidošanā. Lauksaimniecības izcelsmes bioresursu izmantošanas veicināšana īpaši aktīva bija 2007. - 2013. gadā, izveidojoties Latvijā principiāli jaunai nozarei laukos, kurā kā ražošanas resurss tiek izmantota lauksaimnieciskās izcelsmes biomasa. Pēc 2005. gada Latvijā ir attīstìta pirmās paaudzes bioetanola, biodīzeḷdegvielas un biogāzes ražošana. Lauksaimniecības produkcijas izmantošanu pārtikas un nepārtikas produktu ražošanai raksturo 9. attēls.

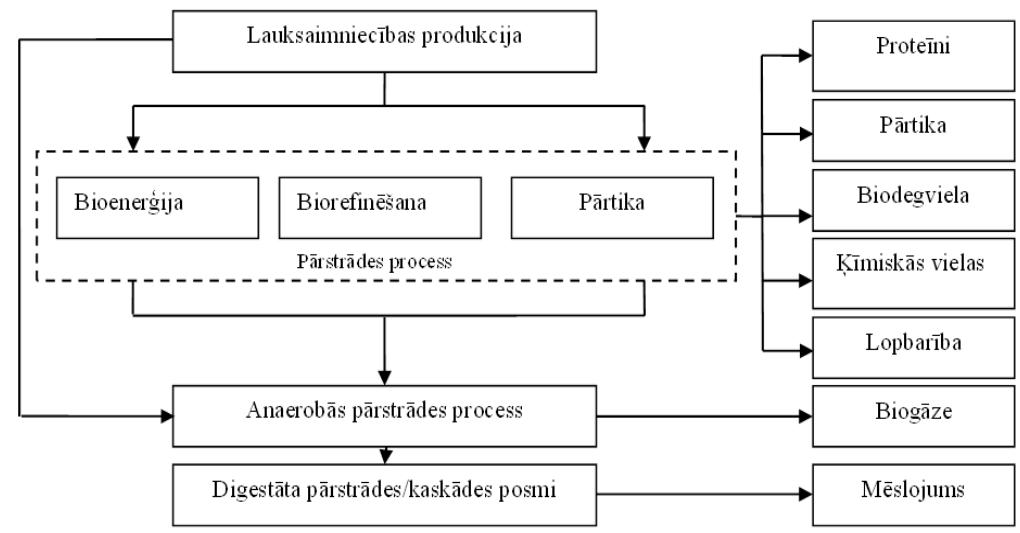

Avots: autora konstrukcija

9. att. Ilgtspējīga lauksaimnieciskās ražošanas sistēma augkopības produkcijas izmantošanai.

Biogāze tiek ražota: no sadzīves atkritumiem - 7 biogāzes stacijās; sadzīves notekūdeņiem - 1; pārtikas ražošanas atlikumiem vai notekūdeņiem - 3 un lauksaimniecības produkcijas - 48 biogāzes stacijās. Izveidojot biogāzes ražotni, ir svarīgi apzināties, ka galvenais ir ilgtspējīgas un konkurētspējīgas lauksaimniecības produkcijas ražošana un tikai sekundāra ir elektroenerğijas ieguve no AER.

Latvijā ir noteikta obligātā 5\% bioetanola piejaukuma norma fosilajai degvielai. No normatīvo aktu viedokḷa Latvijas situācijā viss ir kārtībā. Tomēr ar saražotās biodegvielas realizāciju Latvijas tirgū ir problēmas (Lenerts A., 2013). Darba autors vēlas izdalīt trīs galvenos secinājumus, kuri ir savstarpēji cieši saistīti: 
1. biodegvielas ražošanas nozare latvijā ir nepietiekami saistìta ar citiem tautsaimniecības sektoriem;

2. biodegvielu ražotāji nesadarbojās ar latvijas rapšu un graudu audzētājiem, nepieciešamo izejvielu importēja;

3. neraugoties uz nozari veicinošajiem pasākumiem, neviens latvijas autotransporta uzņēmums nav izveidojis ar biodegvielu darbināmu autoparku, kā tas ir citās es valstīs.

Izvirzot mērkii attīstīt bioekonomikas sektoru un lauksaimniekiem ražot bioproduktus, no uzņēmējdarbības perspektīvu skatupunkta raugoties, ir jārod atbildes uz jautājumu - vai lauksaimnieki saskata iespējas mainīt vinuu rīcībā esošo resursu (zeme, tehnika, darbaspēks, zināšanas) izmantošanas paradumus un vai politisko mērķu sasniegšanai atbalstîtie produktu ražošanas procesi ir ilgtspējīgi savstarpēji saistīto faktoru mijiedarbības rezultātā. Lauksaimniekam ir nepieciešamas zināšanas un spēja saprast un atzît jaunās iespējas (Cohen W.M., 1990).

\subsection{Augkopības ilgtspējīgas intensifikācijas attīstības novērtējums Latvijā}

Ir nepieciešams veikt lauksaimnieciskās ražošanas novērtēšanu ilgtspējas kategorijās, lai pielāgotu to ilgtspējīgai attīstībai (Pope J., 2013). Augkopības ilgtspējīgas intensifikācijas novērtējumam tiek izmantoti dati par 2005. un 2015. gadu. Izmantojot izstrādāto novērtējuma metodi, būs iespējams secināt, kādi būs attīstības rādītāji pēc SEG emisiju samazinošo pasākumu ieviešanas lauksaimniecībā salīdzinājumā ar situāciju, ja šādi pasākumi netiek ieviesti.

Darba autors, nosakot rādītājus, definēja sešas galvenās obligātās ilgtspējīgas attīstības pazīmes:

$>$ attīstības dinamikai ir jābūt pozitīvai uz ilgtspējīgu nākotni;

$>$ ir novērtēti visi ilgtspējīgas intensifikācijas attīstības galvenie faktori un analizēta to savstarpējā saistība;

$>$ novērtēta ekonomisko, sociālo, vides un tehnoloǵiju/inovāciju faktoru savstarpējā saistība;

$>$ kompromisi starp faktoriem ir samazināti līdz minimumam;

$>$ faktoru efektivitātes novērtējums tiek veikts, ievērojot cilvēku vajadzības pēc ilgtspējas;

$>$ novērtējuma metodika ir vienkārša un saprotama visiem sistēmā iesaistītajiem dalībniekiem.

Ttika izveidots kopējais, Latvijas apstākḷiem atbilstošs, raksturīgāko rādītāju saraksts. Novērtējot rādītāja piemērotību, tika ņemta vērā metodika, kuru darbā „Sustainability Indicators: Measuring the Immeasurable?" izstrādājuši S. Bells un S. Morsi (Bell S., 2008), kā arī veiktais pētījums ES valstīs par iespējām ilgtspējas novērtēšanai izmantot Saimniecību uzskaites datu tīkla (SUDAT) rādītājus (Diazabakana A., 2016).

Izmantojot rādītāju novērtējuma līmeņu sistēmu, par sākuma punktu tiek pieņemts lauksaimniecības agro-ekosistēmas sniegto pakalpojumu un preču 
vērtības radītās visu kapitāla formu vērtību izmaiņas. Katrai kapitāla formas izmaiņai nākamajā līmenī tiek noteikti funkciju ietekmējošie kritēriji, no kuriem tiek iegūti raksturojošie rādītāji. Izvirzītais darba mērḳis ir noteikt ilgtspējīgas intensifikācijas attīstību mikroekonomikas jeb saimniecību līmen̄̄, un nākošajā rādītāju atlases solī veikta iespējamās datu bāzes novērtēšana. Sarakstā tika iekḷauti 44 rādīiāji, kuri atbilst ilgtspējas kritēriju novērtēšanai. Dati ilgtspējas rādītājiem analizēti SUDAT datubāzē noteiktajām augkopības saimniecību $(\mathrm{n}=347)$ ekonomiskā lieluma grupām un raksturo ekonomisko faktoru cēloņsakarību. Novērtējuma līmeņos secība attēlota 7. tabulā.

7. tabula

\section{Lauksaimniecības ilgtspējas novērtējuma līmeṇi}

\begin{tabular}{|c|c|c|c|}
\hline 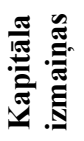 & 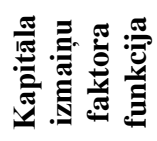 & Kritērijs & Rādītājss \\
\hline \multirow{4}{*}{ 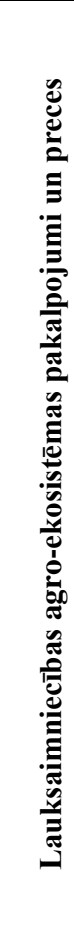 } & 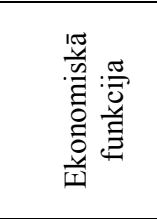 & $\begin{array}{l}\text { Lauku saimniecību ienākumi; } \\
\text { Samazināta atkarība no atbalsta } \\
\text { maksājumiem; Samazināti } \\
\text { lauksaimnieciskās ražošanas } \\
\text { riski. }\end{array}$ & $\begin{array}{l}\text { Ienākumi no } \\
\text { lauksaimniecības } \\
\text { produkcijas; } \\
\text { Lauksaimniecības īpatsvars } \\
\text { IKP; Apdrošināta LIZ } \\
\text { platība. }\end{array}$ \\
\hline & 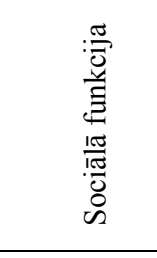 & $\begin{array}{l}\text { Darba apstākḷu uzlabošana; } \\
\text { Darbavietu nodrošināšana lauku } \\
\text { apvidos; Paaudžu } \\
\text { nepārtrauktība lauku } \\
\text { saimniecībās; Lauku } \\
\text { saimniecību ieņēmumi no } \\
\text { nelauksaimnieciskās darbības. }\end{array}$ & $\begin{array}{l}\text { Nodarbinātība } \\
\text { lauksaimniecībā; Risks } \\
\text { atteikties no } \\
\text { lauksaimnieciskās darbības; } \\
\text { Ekonomiskā atkarība no } \\
\text { primārās lauksaimnieciskās } \\
\text { ražošanas. }\end{array}$ \\
\hline & 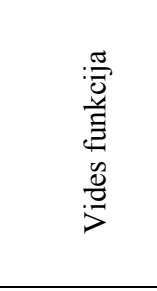 & $\begin{array}{l}\text { Bioloğiskās daudzveidības } \\
\text { saglabāšana; Augsnes kvalitātes } \\
\text { uzturēšana; Emisiju } \\
\text { samazināšana apkartējāt vidē; } \\
\text { Fosilo energijas nesēju } \\
\text { izmantošanas optimizācija; } \\
\text { Biotopu daudzveidības } \\
\text { uzturēšana. }\end{array}$ & $\begin{array}{l}\text { Lauku saimniecības } \\
\text { specializācija; LIZ augseka; } \\
\mathrm{N} \text { izmantošanas bilance: } \\
\text { Augu aizsardzības līdzekli; } \\
\text { Izmantotās enerǵijas } \\
\text { bilance. }\end{array}$ \\
\hline & 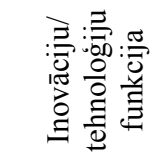 & $\begin{array}{l}\text { Ražotā lauksaimniecības } \\
\text { produkcija; Izmantotā ražošanas } \\
\text { tehnoloǵija; Jaunu zināšanu } \\
\text { apguve. }\end{array}$ & $\begin{array}{l}\text { Investīcijas jaunas tehnikas } \\
\text { iegādei; Tauriņziežu } \\
\text { platības; Lauksaimniecības } \\
\text { produkcijas pārstrāde. }\end{array}$ \\
\hline
\end{tabular}

Avots: autora konstrukcija pēc van Cauwenbergh N. et al., 2007

Izmantojot korelācijas analīzi tika atlasītiti ekonomisko, sociālo, dabas vides un inovāciju/tehnoloǵiju funkciju cēloņsakarību raksturojošie rādītāji. Pēc novērtējuma tika izveidots galīgais ilgtspējīgas intensifikācijas faktoru raksturojošo rādītāju saraksts. Tas sastāv no: pieciem ekonomiskos faktorus 
raksturojošiem; pieciem sociālos faktorus raksturojošiem; pieciem dabas vides faktorus raksturojošiem; pieciem tehnologiiskā/inovāciju faktoru raksturojošiem rādītājiem.

Izveidotajā matricā horizontāli un vertikāli sagrupēti faktoru ilgtspēju raksturojošie rādītāji. Katrs rādītājs secīgi tiek salīdzināts ar pārējiem. Izmantojot 3. formulu, tiek aprēḳināts katra rādītāja būtiskums jeb svars.

$$
S_{i}=\frac{p_{\max }-p_{i}+1}{\sum_{i=1}^{13} p_{i}},
$$

kur: $S_{i}-i$-tā rādītāja svars, $(\mathrm{i}=1,2, \ldots, 13)$,

$p_{i}-i$-tā rādīiāja priekšrocību skaits.

8. tabulā. Katra rādītāja priekšrocību skaita īpatsvars parāda izmantotā rādītāja ietekmes relatīvo svaru diapazonā no 0 līdz 1 . Pēc tam, izmantojot 3. formulu, tiek novērtēts katra faktora ietekmes svarīgums. Augkopības ilgtspējīgu intensifikāciju raksturojošo radītāju nozīmīgums (aprēḳinātie svari) apkopots

8. tabula

Ilgtspējas faktorus raksturojošo rādītāju svari laukkopības saimniecībām Latvijā 2005. - 2015. gadā

\begin{tabular}{|c|c|c|}
\hline $\begin{array}{l}\text { Rādītāja } \\
\text { kods }\end{array}$ & Rādītājs & $\begin{array}{c}\text { Rādītāja aprēḳinātie } \\
\text { svari } S_{i}\end{array}$ \\
\hline EK 4 & LIZ produktivitāte & 0.08 \\
\hline EK 7 & Saimnieciskās darbības diversifikācija & 0.06 \\
\hline EK 9 & Darbaspēka produktivitāte & 0.07 \\
\hline EK 10 & Uzṇēmuma finanšu stabilitāte & 0.08 \\
\hline SO 5 & Darbavietu saglabāšana laukos & 0.06 \\
\hline SO 6 & Darbavietu radīšana laukos & 0.03 \\
\hline SO 9 & Uzṇēmuma sociālā atbildība & 0.10 \\
\hline VI 1 & Emisiju intensitāte agro - ekosistēmā & 0.10 \\
\hline VI 10 & Bioloğiskās daudzveidības saglabāšana & 0.10 \\
\hline VI 6 & Videi draudzīga saimniekošanas sistēma & 0.04 \\
\hline TI 1 & Augkopības produktu attīstība & 0.10 \\
\hline TI 3 & Inovācijas produktu ražošanas tehnologiijā & 0.10 \\
\hline TI 4 & Inovācijas produktu ražošanas sistēmā & 0.08 \\
\hline \multicolumn{2}{|l|}{ Kopā: } & $\sum=1$ \\
\hline
\end{tabular}

Avots: autora konstrukcija

Nākamajā solī tiek veikta rādītāju normalizācija, kuras galvenais uzdevums ir nodrošināt vērtību salīdzināšanu. Darba autors vērtību izlīdzināšanai izmantos min-max normalizāciju, jo tai konkrētajā gadījumā ir vairākas priekšrocības. Ar šo metodi panāk pozitīvas rādītāju vērtības un saimniecību grupas tiek salīdzinātas pret augstākajiem un zemākajiem rādītājiem, kā arī tiek saglabāta esošā attiecība starp vērtībām un dati viegli uztverami. Normalizāciju veic, izmantojot 4 . formulu. 


$$
R_{i}^{\prime}=\frac{r_{i}-r_{\min }}{r_{\max }-r_{\min }}
$$

kur: $R_{i}$ - normalizētā $i$-tā rādītāja vērtība, $(\mathrm{i}=1,2, \ldots, 13)$,

$r_{i}-i$-tā rādītāja faktiskā vērtība, $(\mathrm{i}=1,2, \ldots, 13)$,

$r_{\text {min }}-i$-tā rādītāja minimālà faktiskā vērtība,

$r_{\max }-i$-tā rādītāja maksimālā faktiskā vērtība.

Augkopības ilgtspējīgas intensifikācijas raksturojošo rādītāju normalizētās vērtības apkopotas par 2005. un 2015. gadu. Normalizētās augkopības ilgtspējīgas intensifikācijas faktoru raksturojošo rādītāju vērtības $R_{i}$ tiek aprēkinātas 6 dažādām ekonomiskā lieluma grupu saimniecībām 2005. un 2015. gadā, un tās reprezentē 347 lauku saimniecības, kuras ir specializējušās laukkopībā. 9. tabulā atspoguloti 2015. gada normalizētie rādītāji.

9. tabula

Ilgtspējas faktorus raksturojošie normalizētie vidējie rādītāji laukkopības saimniecībām Latvijā 2015. gadā

\begin{tabular}{|c|c|c|c|c|c|}
\hline 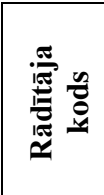 & Rādìtājs & 总 & 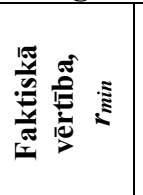 & 绨 & 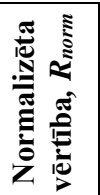 \\
\hline EK 4 & LIZ produktivitāte & EURha $^{-1}$ & 378.15 & 964.32 & 0.56 \\
\hline EK 7 & $\begin{array}{l}\text { Saimnieciskās darbības } \\
\text { diversifikācija }\end{array}$ & $\%$ & 25.7 & 71.32 & 0.80 \\
\hline EK 9 & Darbaspēka produktivitāte & EURcilv $^{-1}$ & 15077.09 & 353360.58 & 0.09 \\
\hline EK 10 & $\begin{array}{l}\text { Uzņēmuma finanšu } \\
\text { stabilitāte }\end{array}$ & $\%$ & 27.96 & 67.24 & 0.26 \\
\hline SO 5 & $\begin{array}{l}\text { Darbavietu saglabāšana } \\
\text { laukos }\end{array}$ & $\begin{array}{c}\text { Cilv100ha- } \\
1\end{array}$ & 0.27 & 2.51 & 0.57 \\
\hline SO 6 & Darbavietu radīšana laukos & $\%$ & 0.03 & 16.86 & 0.05 \\
\hline SO 9 & Uzṇēmuma sociālā atbildība & EURcilv $^{-1}$ & 26.67 & 59.09 & 0.13 \\
\hline VI 1 & $\begin{array}{l}\text { Emisiju intensitāte agro- } \\
\text { ekosistēmā }\end{array}$ & EURha $^{-1}$ & 47.97 & 199.84 & 0.72 \\
\hline VI 10 & $\begin{array}{l}\text { Bioloğiskās daudzveidības } \\
\text { saglabāšana }\end{array}$ & EURha $^{-1}$ & 28,44 & 112.3 & 0.57 \\
\hline VI 6 & $\begin{array}{l}\text { Videi draudzīga } \\
\text { saimniekošanas sistēma }\end{array}$ & $\%$ & 0 & 27.82 & 0.26 \\
\hline TI 1 & $\begin{array}{l}\text { Augkopības produktu } \\
\text { attīstība }\end{array}$ & $\%$ & 0.56 & 10.5 & 0.42 \\
\hline TI 3 & $\begin{array}{l}\text { Inovācijas produktu } \\
\text { ražošanas tehnolog̣ijāa }\end{array}$ & $\%$ & 235.67 & 540.13 & 0.75 \\
\hline TI 4 & $\begin{array}{l}\text { Inovācijas produktu } \\
\text { ražošanas sistēmā }\end{array}$ & EURha $^{-1}$ & 0.3 & 1.03 & 0.46 \\
\hline
\end{tabular}

Avots: autora konstrukcija pēc SUDAT, 2015

Izmantojot 5. formulu tālāk, tika aprēḳināts ilgtspējīgas intensifikācijas attīstības indikators $I A$, kura vērtība uzrāda saimniecību izmaiņas 
ekonomiskajā, sociālajā, vides un inovāciju/tehnolog̣iju attīstībā 2005. un 2015. gadā. Tiek izmantoti iepriekš aprēķinātie katra ilgtspējas faktora rādītāja svari un raksturojošā rādītāja normalizētā vērtība. Lai varētu veikt salīdzinājumu, attīstības indikators tiek aprēķināts saimniecību ekonomiskā lieluma grupās, izmantojot datus par 2005. un 2015. gadu.

$$
I A_{j}^{\prime}=\sum_{i=1}^{13} S_{i} R_{i j}
$$

kur : $I A_{j}$ - ilgtspējīgas intensifikācijas indikators $j$ - tai saimniecību grupai $(\mathrm{j}=1,2, \ldots, 6)$,

$S_{i}$ - ilgtspējas $i$ - tā rādītāja svars, ( $\left.\mathrm{i}=1,2, \ldots, 13\right)$,

$R_{i j}$ - normalizētā $i$ - tā rādîtāja vêrtība saimniecību $j$ grupai.

Izmantojot 5. formulu, aprēķinos ietver rādītāju standartizētās vērtības un svarus, ar kādiem šīs vērtības tiek iekḷautas ilgtspējīgas intensifikācijas attīstības indikatora aprēkinināšanā. Veiktajos attīstības indikatora $I A$ aprēkinos rādītājus summē atbilstoši definētajai trajektorijai. Ja rādītājs atspoguḷo izaugsmi, piemēram, kūtsmēslu daudzuma pieaugumu uz 1 ha LIZ, tiek izmantota plus $(+)$ zīme, šo rādītāju vērtībām pieaugot, IA palielinās. Savukārt, ja jābūt samazinājumam, piemēram, izmantoto augu aizsardzības līdzekḷu daudzums uz 1 ha LIZ, tiek lietota mīnus (-) zīme un, šo rādītāju vērtībām pieaugot, IA samazinās. Aprēḳinātie IA rādītāji apkopoti 10. tabulā.

10. tabula

\section{IA raksturojošo indikatoru radītāji dažāda ekonomiskā lieluma}

laukkopības SUDAT saimniecībām (n=347) Latvijā 2005. un 2015. gadā

\begin{tabular}{|c|c|c|c|c|c|c|c|c|}
\hline \multirow[t]{2}{*}{$\begin{array}{c}\text { Ekonomiskā } \\
\text { lieluma grupa, } \\
\text { tūkst. EUR }\end{array}$} & \multicolumn{2}{|c|}{$\begin{array}{c}\text { Ekonomiskās } \\
\text { ilgtspējas } \\
\text { indekss }\end{array}$} & \multicolumn{2}{|c|}{$\begin{array}{c}\text { Sociālās } \\
\text { ilgtspējas } \\
\text { indekss }\end{array}$} & \multicolumn{2}{|c|}{$\begin{array}{l}\text { Vides } \\
\text { ilgtspējas } \\
\text { indekss }\end{array}$} & \multicolumn{2}{|c|}{$\begin{array}{c}\text { Inovāciju/ } \\
\text { tehnologijiju } \\
\text { ilgtspējas } \\
\text { indekss } \\
\end{array}$} \\
\hline & 2005 & 2015 & 2005 & 2015 & 2005 & 2015 & 2005 & 2015 \\
\hline $\begin{array}{c}\text { Vidējā } \\
\text { saimniecība }\end{array}$ & -0.18 & -0.12 & 0.16 & 0.14 & 0.00 & -0.25 & 0.38 & 0.46 \\
\hline $4<15$ & -0.22 & -0.30 & 0.44 & 0.38 & 0.24 & 0.24 & 0.56 & 0.00 \\
\hline $15<25$ & -0.26 & -0.20 & 0.21 & 0.38 & 0.19 & -0.03 & 0.43 & 0.19 \\
\hline $25<50$ & -0.15 & & 0.31 & 0.24 & 0.11 & -002 & 0.33 & 0.46 \\
\hline $50<100$ & -0.24 & & 0.03 & & 0.13 & 8 & 0.34 & 0.40 \\
\hline $100<500$ & -0.12 & -0.06 & 0.12 & 0.05 & -0.11 & -0.36 & 0.35 & 0.55 \\
\hline$>500$ & 0.30 & 0.30 & 0.02 & 0.00 & -0.48 & -0.48 & 0.27 & 0.55 \\
\hline
\end{tabular}

Avots: autora konstrukcija pēc SUDAT, 2005.,2015.

Analizētie dati uzrāda atšḳirības attīstībā starp dažādām ekonomiskā lieluma saimniecību grupām. Lielās saimniecības ir intensificējušas lauksaimniecības ražošanas procesu, tomēr vienlaikus ir pieaugusi ietekme uz vidi. Turpinoties ekonomiskajiem procesiem laukos, kuru rezultātā pieaug saimniecību fiziskais (apsaimniekotās LIZ platības) un ekonomiskais lielums, pieaugs negatīvā ietekme uz lauku vidi, kura ir pretrunā ar ilgtspējīgas attīstības principiem. Turpmākajā darba gaitā, lai precīzāk novērtētu lauku saimniecību attīstību, darba autors pēc izstrādātās metodoloǵijas veiks novērtējumu 
attīstībai 2005. gadā. Iegūtie attīstības indeksi tiks salīdzināti ar 2015. gada aprēḳinu rezultātiem, un to izmaiṇu raksturs precīzi norādīs uz attīstības tendenci.

Lauksaimniecības ražošanas pieaugošo ietekmi uz vidi apstiprina darba autora analizētie statistikas dati lauksaimniecībā Latvijā. Aprēķini apstiprina un pamato vides ilgtspējas indikatora samazinājuma cēloni, proti, pieaugošu minerālmēslu izmantošanu.

Augkopības nozares attīstības indeksu izmainas attēlotas 10. attēlā.

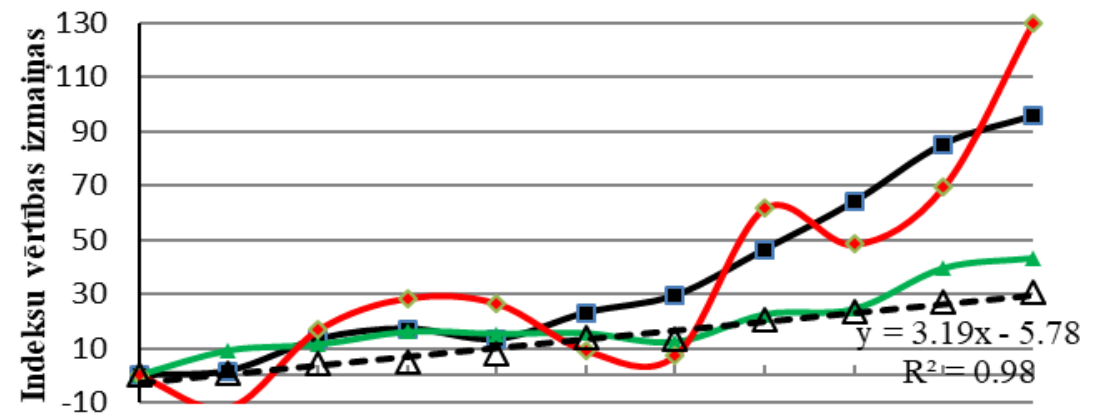

20052006200720082009201020112012201320142015

—-Mineralmēslu izmantošana tūkst. t. _ـ Graudaugu platibas tūkst.ha Gads

- Graudu kopraža tūkst. t.

Avots: autora konstrukcija pēc CSB, 2015

- - Linear (Augsnes SEG CO 2 eq)

10. att. Augkopības nozari raksturojošo rādītāju izmaiṇu indeksi (2005=100) Latvijā 2005. - 2015. gadā.

Augkopības nozares galvenās produkcijas graudu un rapša ražošanas intensifikācija Latvijā notiek, palielinot sintētisko minerālmēslu izlietojumu. SEG emisiju pieaugums augkopības nozarē ir palielinājies par 27\% 2015. gadā salīdzinājumā ar bāzes gadu. Izvēlētā ražošanas attīstība neatbilst ilgtspējīgas intensifikācijas principiem, jo, pēc autora aprēḳiniem, SEG emisiju intensitāte lielāka ir ekonomiski lielo saimniecību grupā, bet tā samazinās ekonomiski mazo saimniecību grupās (Lenerts A., 2015).

Būtiskākais pieaugums ar minerālmēsliem apstrādātajām platībām 2009. 2014. gadā ir graudaugiem, $29.7 \%$. Vēl būtiskāks ir faktors, ka 1.2 reizes ir palielinājusies minerālmēslu izmantošanas intensitāte katram graudaugu sējumu ha, kas veicinās SEG emisiju pieaugumu no lauksaimnieciskās darbības, un netiks sasniegts emisiju ierobežošanai izvirzītais mērḳis.

Pārrēķinot $\mathrm{N}$ minerālmēslu $\mathrm{N}_{2} \mathrm{O}$ emisiju $1.78 \mathrm{~kg} \mathrm{ha}^{-1}$ graudaugu sējumiem uz $\mathrm{CO}_{2}$ eq, tās veido $530.44 \mathrm{~kg} \mathrm{ha}^{-1}$. Pie vidējās graudaugu ražības $4.03 \mathrm{t} \mathrm{ha}^{-1}$ SEG emisijas uz saražotās produkcijas vienu tonnu ir $131.62 \mathrm{~kg} \mathrm{CO}_{2}$ eq. Lai noteiktu, vai šāds rādītājs atbilst vēlamajam SEG emisiju optimumam, nākamajā darba nodaḷā tiks apkopoti ES zinātnieku iegūtie dati un veikta salīdzinoša analīze. 
Izmantojot ilgtermiņa lauksaimnieciskās ražošanas attīstības plānus, ir jāveicina intensīvas piena lopkopības saimniecību veidošanās. Tādējādi tiks nodrošināts papildu organiskais mēslojums pieaugošajām LIZ platībām, aizvietojot minerālmēslus (Lenerts A. 2015). Tāpēc izvairīties no emisijām dabas vidē pilnībā nebūs iespējams. Tomēr ir iespējams sekot līdzi un panākt N minerālmēslu izmantošanas efektivitātes paaugstināšanu, kas vienlaicīgi samazinās ražošanas faktoru izmaksas, kā arī samazinās SEG emisiju intensitāti uz saražotās produkcijas vienību un izmantoto LIZ ha (Lenerts A., 2016).

\section{SEG EMISIJU SAMAZINĀ̄̌ŠNAS PASĀKUMI AUGKOPĪBĀ UN TO IETEKMES UZ DABAS UN EKONOMISKO VIDI IZVĒRTĒJUMS}

Nodalıas saturs darbā veidots no 23 lpp., kurās ietilpst 7 tabulas un 14 attēli. Nodạ̄ā veikta SEG emisiju robežsamazinājuma izmaksu analīze. Noteikti Latvijas apstākḷiem piemēroti SEG emisiju samazināšanas pasākumi augkopībā. Veikta SEG emisiju samazinājuma prognoze.

Nodaḷā izvirzītā tēze: SEG samazinošo pasākumu ieviešana augkopībā nodrošinās dabas vides saglabāšanu un ekonomiskos ieguvumus lauksaimniecības ilgtspējīgai attīstībai.

Pēc autora veiktajiem aprēķiniem darba trešajā nodą̣ā, papildu LIZ iesaistīšana produkcijas ražošanā pie esošajām ražošanas tehnologijām un saražotās produkcijas sortimenta ievērojami pārsniegs Latvijai atḷauto (Parīzes vienošanās) SEG emisiju apjomu no lauksaimniecības. SEG emisiju faktiskais pieaugums līdz 2015. gadam un prognozes pieaugumam vai samazinājumam līdz 2020. gadam raksturotas 11. attēlā.

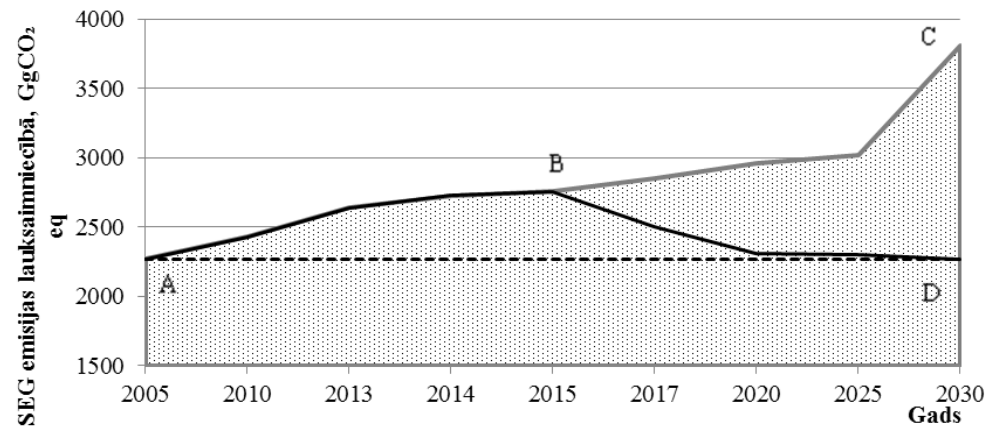

Lauksaimnieciba ----2005. gada līmenis — Pieaugums un samazinājums

Avots: autora konstrukcija

11. att. Lauksaimniecības SEG emisijas Latvijā 2005. - 2015. gadā un izmaiṇu prognoze līdz 2030. gadam. 
Lai noteiktu augkopības SEG emisiju samazināšanas iespējas, autors veica alternatīvā SEG samazinājuma scenārija aprēķināšanu (A uz D 11. attēlā). Identificējot Latvijas augkopībai piemērotus SEG samazināšanas pasākumus, tiks noteikts samazinājuma potenciāls 2020. gadā. Tātad pētījuma galvenais mērḳis ir meklēt iespējas veidot lauksaimniecības attīstību Latvijā, vienlaikus nodrošinot ekonomisko interešu konverğenci ar ietekmi uz vidi. Darba ceturtajā nodạ̦ā veiktā ilgtspējīgas intensifikācijas novērtējuma rezultāti norāda uz augkopības saimniecību attīstību, kad vienlaicīgi ar ekonomisko izaugsmi tiek palielināta negatīvā ietekme uz dabas un sociālo vidi, kas ir pretrunā ar ilgtspējas principiem. Šajā darba nodaḷā autors veicis aprēḳinus cēloṇsakarību konstatēšanai un iespējamo pasākumu noteikšanai, lai augkopības saimniecības Latvijā varētu nodrošināt ekonomiskās izaugsmes un dabas vides saglabāšanas simbiozi. Mērķa sasniegšanai izvirzīti atbilstoši 5. nodaļas darba uzdevumi: izskaidrot SEG emisiju robežsamazinājuma izmaksu analīzes metodi; veikt iespējamo SEG mazinošo pasākumu teorētisko novērtējumu augkopībai Latvijā; izmantojot daudzdimensiju hierarhijas faktoranalīzi, noteikt ieviešamos pasākumus; aprēḳināt SEG emisiju samazinājumu un ekonomiskos ieguvumus/izdevumus pēc pasākumu ieviešanas, izmantojot McKinsei (McKinsey.. 2010) izstrādāto metodologiju, un veidot samazināšanas pasākumu izmaksu un ieguvumu līkni (Marginal Abatement Cost Curve, MACC).

\subsection{SEG emisiju robežsamazinājuma izmaksu analīze}

Robežsamazinājuma izmaksu analīzes metode pirmo reizi tika izstrādāta 20. gs. 70. gados.

Robežsamazinājuma izmaksu analīzes metode MACC (Marginal Abatement Cost Curve) lauksaimniecībā plaši tiek izmantota, lai noteiktu spēju pielāgoties klimata izmaiņu mazināšanai (Wreford A., 2010).

Konstruētās robežsamazinājuma izmaksu līknes informācija:

$>$ lauj novērtēt atsevišķu SEG samazinošo pasākumu ekonomisko izdevīgumu, kas nozīmē samazināt emisijas un ietaupît finanšu resursus, kā arī sniedz informāciju, kādu pasākumu ieviešana ir iespējama pie noteiktiem nosacījumiem. Izmaksu izdevīgiem pasākumiem ir „negatīvas izmaksas", un tie attēloti zem horizontālās ass kreisajā pusē. Izmaksu daḷēji izdevīgie un neizdevīgie pasākumi attēloti virs horizontālās ass grafika labajā pusē;

$>$ vizualizē SEG emisiju samazinājuma potenciāla lielumu katram pasākumam, kas norādīts kā attiecīgā grafiskā attēla platums.

Pasākumu izvēles un ieviešanas novērtējumu apgrūtina esošo saimniecību finanšu iespējas, kas ir cieši saistītas ar to ekonomisko lielumu. Ekonomiski lielajās saimniecībās (pēc darba ceturtajā nodaḷā veiktā novērtējuma) ir lielāki ieguldījumi tehnikas, iekārtu un tehnolog̣iju maiņai, tāpēc šo saimniecību potenciāls samazināt emisijas un vienlaicīgi paaugstināt saražotās produkcijas apjomu, pēc autora domām, ir augstāks. 
Augkopības SEG emisiju samazināšanas pasākumu ieviešanas izmaksas tiek noteiktas, izmantojot produkcijas ražošanas bruto seguma izmaiņas (izteiktas kā EUR ha ${ }^{-1}$ ), un aprēkinātas, izmantojot 6 . formulu. Izmantojot MAC līknes konstruēšanas pieeju „no apakšas uz augšu”, tiek veikts katra ieviešamā pasākuma bruto seguma novērtējums, kurš tiek salīdzināts ar bāzes scenārija (LLKC bruto seguma dati) izmaksām. SEG samazinājuma pasākumu izmaksu un ieguvumu līknes aprēḳina modelis attēlots 12. attēlā.

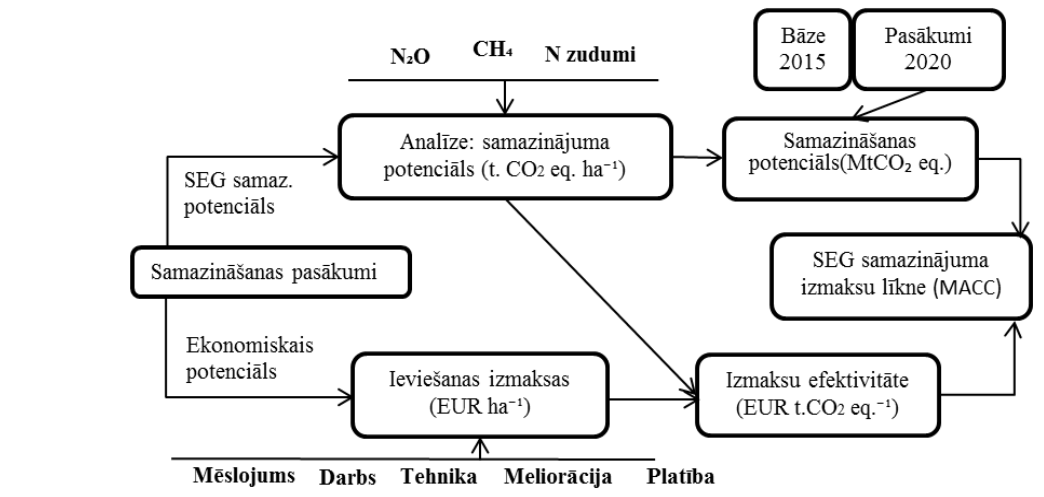

Avots: autora konstrukcija

\section{2. att. SEG emisiju samazināšanas pasākumu izmaksu un ieguvumu līknes aprēḳina modelis augkopībai Latvijā.}

Šāda pieeja nodrošina iespējas salīdzināt augkopības saimniecībā izmantoto ražošanas faktoru atdevi, kā arī saražoto produkciju pirms un pēc SEG samazinājuma pasākumu ieviešanas, izmantojot 6 . formulu.

$$
\Delta B S_{p . c .}=\sum_{t=1}^{5}\left(R_{c} * C_{c} * R I_{p . c .}\right)-M_{c}-I_{p . c .}-Z_{p . c .}-B S_{c},
$$

kur: $\Delta B S_{p . c .}-$ bruto seguma izmainas pēc SEG emisiju samazināšanas pasākuma ieviešanas,

$T$ - pasākuma realizēšanas laiks pēc ieviešanas, $(\mathrm{t}=1,2, \ldots, 5)$,

$R_{c}$-augkopības produkcijas $c$ vidējā ražǐba,

$C_{c}$ - augkopības produkcijas $\boldsymbol{c}$ vidējā realizācijas cena,

$R I_{p . c .}-$ augkopības produkcijas $\boldsymbol{c}$ vidējās ražības pieaugums \%, ieviešot pasākumu $\boldsymbol{p}$,

$M_{c}$ - ražošanas main̄̄gās izmaksas produkcijai $\boldsymbol{c}$ pirms pasākuma ieviešanas,

$I_{p . c .}-$ pasākuma $\boldsymbol{p}$ ieviešanas izmaksas augkopības produkcijai $\boldsymbol{c}$,

$Z_{p . c .}-$ augkopības produkcijas $\boldsymbol{c}$ ieṇēmumu samazinājums, ieviešot pasākumu $\boldsymbol{p}$,

$B S_{c}$ - bruto segums produkcijai $\boldsymbol{c}$ pirms pasākuma ieviešanas.

Augkopības SEG emisiju samazinājuma pasākumu izmaksu efektivitāti IE aprēkinina pēc 7. sakarības.

$$
I E_{p . c .}=\frac{\Delta B S_{p . c .}}{\Delta S E G_{p}},
$$


kur: $I E_{p . c .}-\mathrm{SEG}$ emisiju samazinājuma pasākuma $\boldsymbol{p}$ izmaksu efektivitāte produktam $\boldsymbol{c}$, $\triangle B S_{\text {p.c. }}$ - bruto seguma izmaiņas produktam $\boldsymbol{c}$, ieviešot pasākumu $\boldsymbol{p}$,

$\triangle S E G_{p}-\mathrm{SEG}$ samazinājums, ieviešot pasākumu $\boldsymbol{p}$.

\subsection{Augkopības SEG emisiju samazināšanas pasākumu nepieciešamība}

Lai konstatētu, vai Latvijā ekonomiskā pieauguma rādītāji apsteidz ietekmes uz vidi palielinājumu, izmantojot ražošanas faktorus, darba autors noteica SEG emisiju intensitāti uz saražotās produkcijas vienību 2009. - 2014. gadā.

Pētījuma turpinājumā kā atskaites punkts tiek izmantota ekonomikā labi zināmā ražošanas faktoru funkcija 8 . sakarība.

kur: $\mathrm{P}$ - produkcijas izlaide,

$$
P=f\left(x_{1}, x_{2} \ldots, x_{n}\right),
$$

$\mathrm{x}_{1}, \mathrm{x}_{2}, \ldots \mathrm{x}_{\mathrm{n}}-$ izmantotie ražošanas faktori.

Šĩ funkcija parāda, kā un cik ātri resursi tiek pārvērsti gala produktā, piemēram, cik vien̄ibu attiecīgā $\mathrm{N}$ minerālmēslojuma ir jālieto, lai iegūtu plānoto ražu vai iegūtu maksimālo teorētiski iespējamo produkcijas daudzumu, pamatojoties uz racionālu izmaksu - ieguvumu analīzi un pamatotu izvēli. N minerālmēslu izmantošanas un saražotās ziemas kviešu produkcijas kopsakarības atspoguḷotas 13. attēlā.

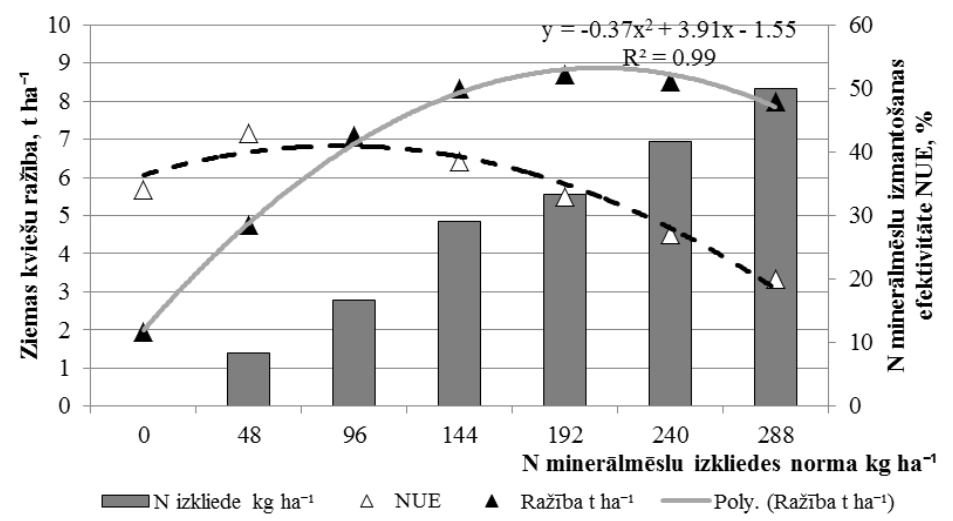

Avots: autora konstrukcija pēc Hawkesford J. M., 2014

\section{3. att. Kviešu ražība un minerālmēslu izmantošanas efektivitāte.}

Kamēr nav veikti zinātniski pamatoti pētījumi par SEG emisijām no augsnes Latvijas apstākḷos, aprēḳinos ir jāizmanto IPCC noteiktās vadlīnijas. SEG emisiju veidošanās ir atkarīga no audzējamā kultūrauga. Tāpēc lēmumu pieņemšanas procesā, izvēloties konkrēto kultūraugu, svarīgi saprast, kādiem mērḳiem izaudzētā produkcija tiks izmantota. Latvijas augkopības saimniecību sējumu struktūrā pārliecinoši dominē kultūraugi ar augstāko SEG emisiju uz saražotās produkcijas vienību. Darba trešās nodalas atspoguḷotie dati uzrāda, ka 2015. gadā $35.7 \%$ no kopējās sējumu struktūras aizṇēma graudaugi, kuru 
audzēšana ir ar augstu SEG emisiju veidošanās intensitāti. Pēc autora domām KLP nākotnē būs jāievieš koriǵējoši pasākumi sējumu struktūras maiṇai, jo pretējā gadījumā nāksies samazināt ražošanas apjomus radīto SEG emisiju dēl, kas vienlaicīgi kavēs lauksaimniecības attīstību. Autoraprāt, ņemot vērā, ka spēku ir zaudējis ierobežojums cukura ražošanai Latvijā, būtu nepieciešamība atgriezties pie nopietna izvērtējuma sējumu struktūrā iekḷaut cukurbietes, jo to audzēšanas SEG emisiju intensitāte ir viszemākā uz produkcijas vienību.

Nākamajā novērtējuma solī darba autors veica SEG emisiju intensitātes novērtējumu Latvijas augkopības saimniecībās saražotajiem ziemas kviešiem. Aprēkininiem tika izmantoti CSP nepublicēti dati, kurus pēc darba autora lūguma sagatavoja pārvaldes speciālisti. Emisiju intensitāte tika aprēķināta, izmantojot dzīves cikla analīzes metodi (LCA), lai iegūtie dati būtu salīdzināmi, analizējami un interpretējami ar citās valstīs veiktajiem aprēķiniem. Salīdzinājumam izvēlēti pēc identiskas metodes aprēḳinātie rādītāji ziemas kviešu audzēšanā radītajām SEG emisijām Apvienotajā Karalistē (Berry P. M., 2010) un Polijā (Wojcik-Gront E., 2016). Kviešu audzēšanas raksturojošo SEG emisijas faktoru rādītāji aprēḳināti, rezultātu izsakot $\mathrm{kg} \mathrm{CO}_{2}$ eq vienam saražotās produkcijas kg.

SEG emisiju aprēķināšana kviešu sējumu ha veikta pēc P. M. Berrija (2010) aprakstītās metodikas. Izmantojot izveidoto aprēķinu modeli un iegūtos datus, tika novērtēta augkopībā audzēto ziemas kviešu SEG emisiju intensitāte Latvijā 2009. - 2014. gadā. Iegūtie rezultāti atspoguḷoti 14. attēlā.

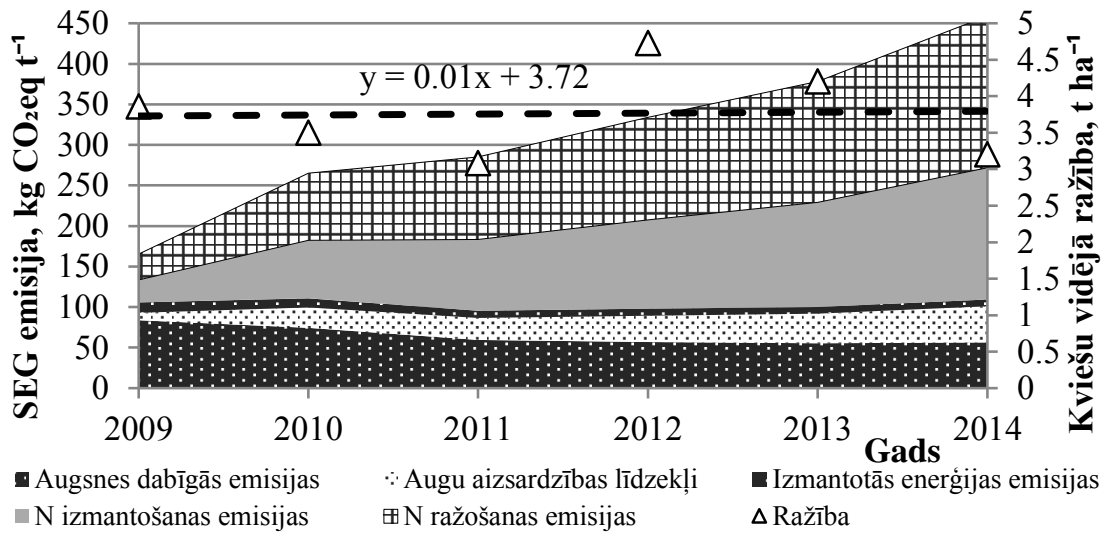

Avots: autora konstrukcija

\section{4. att. SEG emisiju intensitāte ziemas kviešu sējumos Latvijā 2009. - 2014. gadā, $\mathrm{kg} \mathrm{CO}_{2}$ eq t$^{-1}$.}

Iegūtie rezultāti apstiprina darba autora pieņēmumu, ka attīstībai bez papildu pasākumiem SEG emisiju samazināšanā tālākas lauksaimniecības attīstības iespējas nepastāv. SEG emisiju intensitāte ir pieaugusi par $250 \%$, sasniedzot $450 \mathrm{~kg} \mathrm{CO}_{2} \mathrm{eq} \mathrm{ha}^{-1}$. Savukārt graudaugu ražības vidējais pieaugums 
ir 0.01 t. ha $a^{-1}$. Latvija kā viena no ES dalībvalstīm ir apṇēmusies reaǵēt uz klimata izmain̄ām un samazināt SEG emisijas. Pasaulē veiktie pētījumi (Repetto R. et al., 2010) apliecina, ka, izmantojot jau esošās tehnologijas, līdz 2050. gadam SEG emisijas var tikt samazinātas par 80\%, būtiski neietekmējot ekonomisko izaugsmi.

Pētījumos konstatētās galvenās atziṇas:

$>$ svarīgi izmantot tā saucamos ,ierobežot un tirgoties” (cap and trade) režīmus, kas veicina tirgus iespējas ,atgūt” līdzsvaru, nosakot, kur un kad samazināt emisijas;

$>$ stratēgiskas investīcijas infrastruktūrā un institucionālas izmaiņas būtiski veicina zemu oglekḷa tehnoloǵiju attīstību;

> svarīgi radīt priekšrocības zemu izmaksu oglekḷa piesaistes pasākumiem, izmantojot nacionālās un starptautiskās atbalsta programmas.

ES lauksaimniecība ietilpst ne-ETS sektorā, tāpēc pirmā minētā atzina, kas paredz tirgus mehānismu ieviešanu, tiešā veidā nav izmantojama. Atlikušie divi ieteikumi ir būtiski, īpaši attiecībā uz oglekḷa piesaistes pasākumiem. Saistībā ar SEG emisiju samazināšanu lauksaimniecībā ārzemju pētnieki (Smith P. et al., 2008) saredz trīs darbības virzienus:

> emisiju samazināšana - šis mehānisms saistāms ar efektīvu SEG emisijas samazināšanas metožu izmantošanu;

> oglekḷa piesaistes uzlabošana - šis mehānisms saistāms ar augsnes organiskajā dạ̣ā uzkrātā oglekḷa zudumu samazināšanu. Tie ir zemes apsaimniekošanas risinājumi, kas palielina fotosintēzes procesā uzṇemto oglekli un novērš uzkrātā oglekḷa nokḷūšanu atmosfērā;

$>$ emisiju radošu lauksaimniecības prakšu aizvietošana vai papildināšana ar klimatam draudzīgākām praksēm - šis mehānisms saistās ar augu un lauksaimniecības atlikumu izmantošanu atjaunojamās enerǵijas, piemēram, biogāzes, bioetanola vai biodīzel̦a, ražošanai.

Darba autors veica SEG emisiju mazināšanas pasākumu salīdzinošo izpēti, izmantojot jau iepriekš veiktos pētījumus citās valstīs un ievērojot autora definētus pasākumu atlases kritērijus:

$>$ pasākuma ieviešana būtiski nemainīs lauksaimnieciskās ražošanas sistēmu saimniecībās;

$>$ pēc pasākuma ieviešanas ir iespējams novērtēt ieviešanas izmaksas un SEG samazinājumu saimniecībā;

$>$ iegūtos datus ir iespējams vispārināt un attiecināt uz lauksaimniecību kopumā.

Identificējot pasākumus, kuri var samazināt SEG emisijas no lauksaimnieciskās ražošanas, bija svarīgi atlasīt tādus pasākumus, kuru ieviešana būtiski ietekmētu SEG emisiju aprēkināšanā izmantotos rādītājus. SEG mazināšanas pasākumam ir jābūt ietekmei uz NIR un jāatbilst noteiktiem kritērijiem:

$>$ pasākuma efektivitāte ir pierādīta un zinātniski pamatota (publicēti pētîjumi zinātnisko rakstu krājumos); 
$>$ pasākuma samazinājuma efektu var izmantot SEG aprēķinu metodikā, kuru izmanto NIR sagatavošanai (piemēram, izmantotās kūdrāju (histosols) platības augkopībā);

> ir noteikti rādītāji/indikatori pasākuma īstenošanas kontrolei (piemēram, slāpekḷa mēslojuma izmantošanas efektivitāte, NUE);

$>$ pasākuma ieviešana būtiski nemainīs lauksaimnieciskās ražošanas sistēmu lauku saimniecībās;

$>$ ir iespējams novērtēt ieviešanas izmaksas un SEG samazinājumu saimniecībā pēc pasākuma ieviešanas.

Situācijas izvērtējums SEG emisiju samazināšanas pasākumu klasificēšanas jomā ḷauj Latvijā piemērot SEG pasākumu sadalījumu pēc diviem galvenajiem prioritārās ietekmes virzieniem:

$>$ augkopībā ieviešamie SEG emisiju samazinošie pasākumi;

> lopkopībā ieviešamie SEG emisiju samazinošie pasākumi.

Izpētes sākuma posmā tika izveidots garš pasākumu saraksts, pēc tam, pamatojoties uz augkopības un lopkopības nozaru ekspertu vērtējumu, kā Latvijas apstākliem piemēroti tika identificēti 19 SEG emisiju samazinoši pasākumi, kas pielietojami laukkopībā (National Research..., 2016). Šos pasākumus SEG emisiju samazināšanas problēmas risināšanai augkopībā darba autors sadala piecās alternatīvās grupās. Pirmajā grupā ietilpstošie samazinošie pasākumi, kuri nodrošina slāpekḷa aprites precīzu vadību. Otrā SEG samazinošo pasākumu grupa ir saistīta ar brīvā slāpekḷa iespējamo piesaisti, izmantojot, piemēram, tauriņziežu sējumus. Trešā samazinošo pasākumu grupa - oglekḷa uzglabāšana augsnē, kuru panāk ar augsnes fizikāli - ḳīmisko īpašību uzlabošanu. SEG emisiju samazināšanas ceturtā alternatīva ir biologiskās lauksaimniecības intensīva attīstīšana. Savukārt piektā samazinošo pasākumu grupa ir saistīta ar lauksaimnieciskās ražošanas intensitātes samazināšanu, kas panākama ar ilggadīgo zālāju ierīkošanu organiskajās augsnēs un ātraudzīgo koku sugu stādīšanu lauksaimniecības zemē.

\subsection{Latvijas apstākḷiem piemēroti SEG emisiju samazināšanas pasākumi augkopībai}

Pētījumā ekspertu pieredze un zināšanas tika izmantotas, lai pēc iespējas vispusīgi novērtētu izvēlēto SEG emisiju mazināšanas pasākumu iespējamos ieviešanas šķēršlus lauksaimniecībā. Ekspertu aptaujā iegūto datu apstrādi autors veica, izmantojot amerikāṇu matemātiḳa Saati T. hierarhiju analīzes metodi (AHP) (Saaty T.,1981).

Pielāgojot hierarhiju analīzes metodes algoritmu augkopības sektora SEG emisiju mazināšanas pasākumu novērtēšanai Latvijas lauksaimniecībā, tika izstrādāta hierarhijas piramīda, kura sastāv no četriem līmeņiem. Hierarhijas pirmajā līmenī tiek izvirzīts mērḳis - lauksaimniecības SEG emisiju samazināšanas pasākumu ieviešana augkopībā. Otrajā līmenī eksperti novērtēja mērḳa sasniegšanu ietekmējošos ekonomiskos, sociālos, vides un 
tehnoloǵiskos faktorus. Hierarhijas trešajā līmenī eksperti noteica katra faktora ietekmējošo kritēriju svarīgumu saistībā ar sasniedzamo mērķi. Ekonomiskos faktorus eksperti vērtēja, izmantojot vairākus kritērijus: pieejamais ES kopējās lauksaimniecības politikas atbalsta finansējums; darbavietu skaita izmaiṇas lauku saimniecībās; lauku saimniecību ekonomiskā ilgtspēja; lauku saimniecību finansiālās iespējas un SEG mazināšanas pasākumu ietekme uz saražoto produkciju (15. attēls).

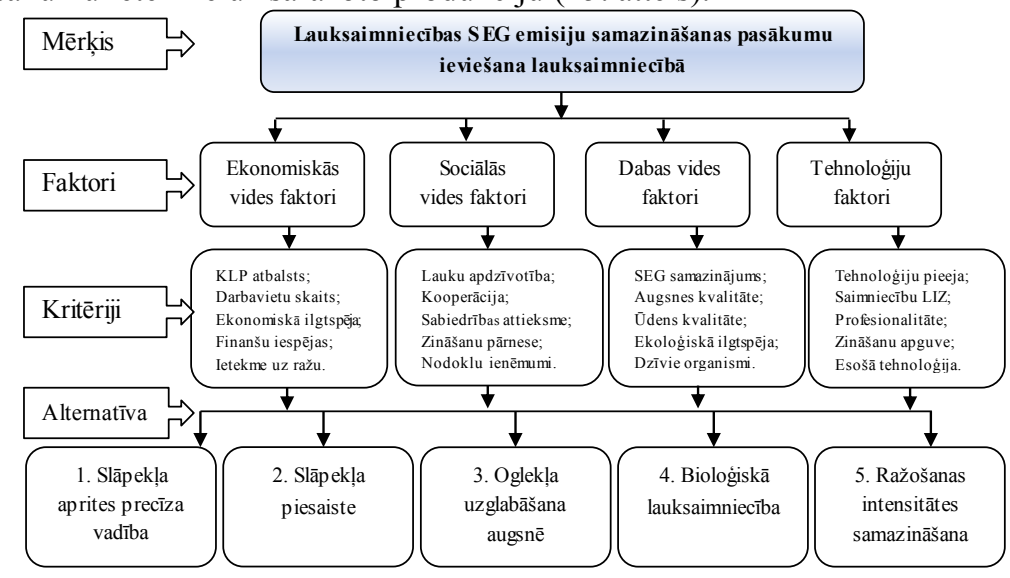

Avots: autora konstrukcija

\section{5. att. SEG emisiju mazināšanas pasākumu novērtēšanas hierarhijas piramīda.}

Sociālos faktorus vērtēja, izmantojot kritērijus: lauku vides apdzīvotības izmainas; lauku saimniecību savstarpējā sadarbība kooperējoties; sabiedrības un sabiedrisko organizāciju ietekme; lauku saimniecību īpašnieku/vadītāju zināšanu apguve un lauku saimniecību iemaksātie nodokḷi pašvaldību budžetā.

Dabas vides faktorus vērtēja, izmantojot kritērijus: SEG emisiju iespējamais samazinājums; augsnes kvalitatīvo rādītāju uzlabošanās; ūdens kvalitatīvo rādītāju uzlabošanās; lauksaimnieciskās ražošanas ekologiiskā ilgtspēja un dzīvo organismu, sugu vairošanās.

Tehnologiskos faktoru vērtēja, izmantojot kritērijus: jauno tehnoloǵiju pieejamība; saimniecības apstrādātā lauksaimniecībā izmantotā zeme; profesionālās zināšanas; esošā tehnolog̣ija un zināšanu ieguve. Hierarhijas ceturtajā līmen̄i ekspertiem tika piedāvātas piecas alternatīvas problēmas atrisināšanai. Tās tika izstrādātas, grupējot SEG mazināšanas pasākumus pēc pazīmes, kā samazinājuma efekts panākams.

Pirmā iespējamā alternatīva - slāpekḷa aprites precīza vadība, kuru panāk ar: precīzu minerālmēslu lietošanu; integrētās lauksaimniecības ieviešanu; tiešu minerālmēslu iestrādi augsnē; nitrifikācijas inhibitoru pielietošanu; mēslošanas plānošanu un augsnes kalı̧košanu. 
Otra iespējamā alternatīva - slāpekḷa piesaiste, kuru panāk ar: tauriņziežu platību palielināšanu; tauriņziežu pasēju (slāpekḷa piesaiste); zaļmēslojuma augu sēšanu melnajā papuvē; biomasas produktivitātes paaugstināšanu.

Trešā iespējamā alternatīva - oglekḷa uzglabāšana augsnē, kuru panāk ar: augsnes fizikāli-ķīmisko īpašību uzlabošanu; augu atlieku (salmu) ierobežotu novākšanu no lauka; minimālu augsnes apstrādi un meliorācijas sistēmas uzturēšanu.

Ceturtā iespējamā alternatīva - biologiskas lauksaimniecības intensīva attīstīšana.

Piektā iespējamā alternatīva - ražošanas intensitātes samazināšana, kas panākama ar: ilggadīgo zālāju ierīkošanu organiskajās augsnēs; ātraudzīgo koku sugu stādīšanu lauksaimniecības zemē.

Pētījuma mērḳa sasniegšanai svarīga ir atbilstošu, kompetentu ekspertu izvēle.

Par ekonomiskās jomas ekspertiem tika pieaicināti:

1. Arnis Burmistrs - Latvijas Zemnieku saeimas valdes loceklis, z/s Vilcini īpašnieks,

2. Gatis Bērziņš - SIA Precision Farming, Agricon valdes priekšsēdētājs.

Sociālās jomas novērtēšanai tika uzaicināti eksperti:

3. Oskars Balodis - Latvijas Lauku konsultāciju centra (LLKC) augkopības nodaḷas vadītājs,

4. Agate Zālīte - LAD Sabiedrisko attiecību daḷas sabiedrisko attiecību speciāliste.

Vides jomas novērtēšanai tika uzaicināti eksperti:

5. Agita Gancone - LR VARAM vecākais referents,

6. Laima Bērziņa - Dr. sc.ing., LLU Vides un ūdenssaimniecības katedras vadošā pētniece.

Savukārt inovāciju/tehnologiju jomas novērtēšanai tika uzaicināti eksperti:

7. Pēteris Rivža - Dr. habil. sc. ing., LLU Datoru sistēmu katedras profesors, vadošais pētnieks,

8. Dzidra Kreišmane - Dr. agr., LLU Agrobiotehnologijas institūts, asociētā profesore, vadošā pētniece.

Visu ekspertu vērtējumus apkopo, aprēḳinot katra vērtējuma aritmētisko vidējo un izkliedi. Izkliedi grafiskajos attēlos parāda, izmantojot amplitūdu no minimālām līdz maksimālajām katra konkrētā vērtējuma skaitliskajām vērtībām. 16. attēlā atspoguḷotās dabas vides un ekonomiskās vides faktoru grupas eksperti ir vērtējuši salīdzinoši līdzīgi, prioritāti atdodot ekonomiskajiem faktoriem (0.38). Tomēr pastāv salīdzinoši liela izkliede attiecībā uz dabas vides faktoriem, kas norāda, ka pastāv ievērojama viedokḷu atškirīiba par to būtiskumu. Vislielākā vienprātība ekspertu vidū ir par tehnologisko faktoru nozīmi (0.14), ko pamato neliela rezultātu izkliede. Vislielākā vienprātība ekspertu vidū ir par tehnologisko faktoru nozīmi (0.14), ko pamato neliela rezultātu izkliede. Rezultāti apkopoti 16. attēlā. 


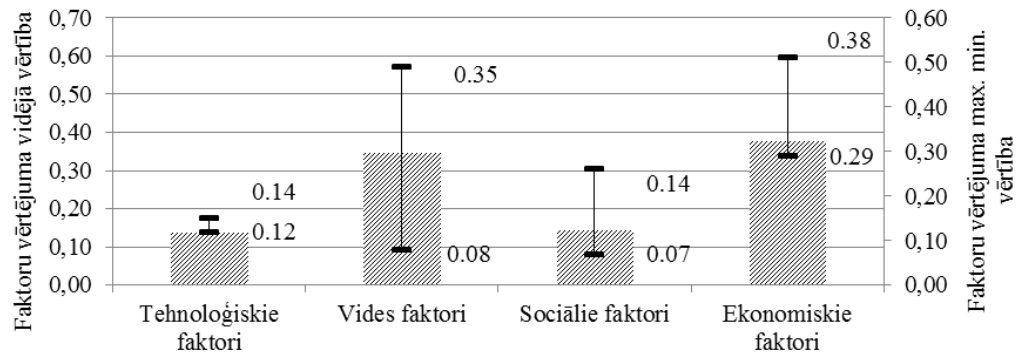

"Vid.aritm. -Max. -Min.

Avots: autora konstrukcija

16. att. Lauksaimniecības SEG emisiju samazināšanas pasākumu ieviešanas sociālās, ekonomiskās, dabas vides un tehnologisko faktoru grupu ekspertu vērtējums.

Lai darba autors noteiktu, kuru no SEG samazināšanas pasākumu alternatīvajām grupām pēc ekspertu novērtējuma izmantot tālākajos aprēķinos, tiek analizēti ekspertu vērtējuma rezultāti pēc visiem 20 kritērijiem. SEG samazināšanas alternatīvu grupu vērtējumā ekspertu vidū nepastāv liela vienprātība par pasākumiem, kuru ieviešana saistīta ar ražošanas intensitātes samazināšanu, biologiskās saimniekošanas sistēmas ieviešanu, slāpekḷa piesaisti un $\mathrm{CO}_{2}$ uzglabāšanu augsnē. Tas nozīmē, ka ekspertiem ir bijuši dažādi viedokḷi. Zemāks vērtējums ir trešajai mazināšanas pasākumu grupai „ $\mathrm{CO}_{2}$ uzglabāšana augsnē” (0.13). Otrs zemākais vērtējums mazināšanas pasākumu grupai „slāpekḷa piesaiste”. Ekspertu vidū augstāko vērtējumu ir saṇēmis pasākums „bioloǵiskās lauksaimniecības sistēmas ieviešana”, tomēr, kā tas redzams 17. attēlā, tas tiek vērtēts vispretrunīgāk.

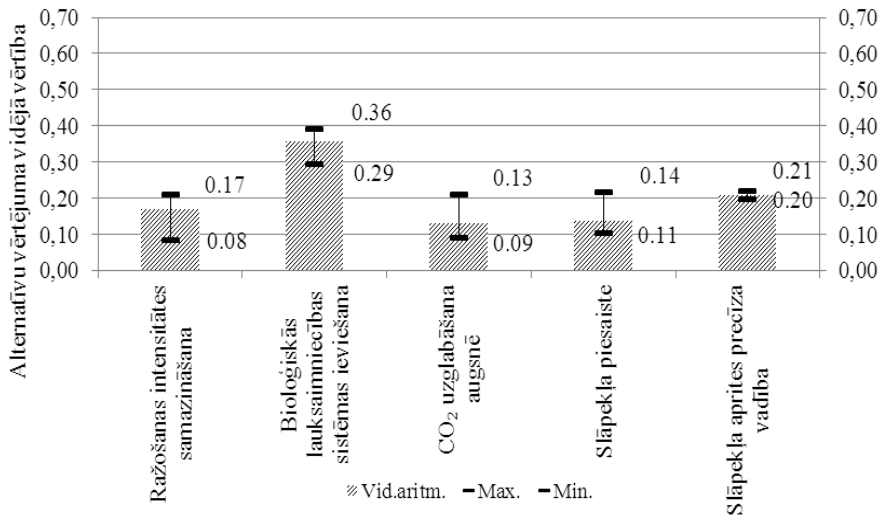

है

Avots: autora konstrukcija

17. att. Lauksaimniecības SEG emisiju samazināšanas alternatīvo pasākumu ekspertu vērtējums. 
Ekspertu vērtējumā lielākā vienprātība ir par pasākumu grupu „slāpekḷa aprites precīza vadība". Autors vēlas uzsvērt, ka, vērtējot šo pasākumu grupu, ekspertu viedokḷi praktiski sakrīt, un var apgalvot, ka pastāv vienprātība, kas norāda uz nepieciešamību attīstīt efektīvu zemes resursu izmantošanas sistēmu, tai skaitā - minerālmēslu izmantošanu.

Tā kā pēc ekspertu vērtējuma lielākā vienprātība ir par nepieciešamību nodrošināt precīzu slāpekḷa aprites vadību, darba autors SEG samazinājuma pasākumu izmaksu un ieguvumu aprēḳinu veiks šai grupai. Kā nākošo SEG samazinājuma izmaksu un ieguvumu aprēḳinu varētu veikt pasākumam „biologiskās saimniekošanas sistēmas ieviešana” Latvijā. Tomēr, autoraprāt, šāds attīstības virziens būtiski ietekmētu ekonomiskās izaugsmes iespējas lauksaimniecībā, jo bioloǵiski saražotā produkcija ir ievērojami dārgāka. Biologiskās saimniekošanas sistēmas intensīvu ieviešanu Latvijā varēs realizēt tad, kad tiks precīzi veikta LIZ kvalitatīvā novērtēšana un noteikts tās labākais funkcionālais izmantošanas veids.

\subsection{Augkopības SEG emisiju samazināšanas pasākuma „slāpekḷa aprites precīza vadība" izmaksu un ieguvumu aprēḳins}

Ieviešanas izmaksas (izteiktas kā EUR ha ${ }^{-1}$ LIZ) ir aprēḳinātas, izmantojot 9. formulu, izvērtējot izraisītās izmaiņas: iegūtajā ražāa, ražošanas izmaksās (mēslojums, pesticīdi, sēkla u.c.), darbaspēka ieguldījumā, tehnikas izmaksās, salīdzinot augkopības praksi saskaṇā ar bāzes scenāriju jeb saimniekošanu „pa vecam" katram augkopībā izmantotajam zemes ha un kultūraugam. Izmantojot pieeju „,no apakšas uz augšu”, tiek pieņemts, ka lauku saimniecības, tiecoties palielināt savus ien̦ēmumus vai peḷnu, saskarsies ar noteiktiem ierobežojumiem attīstībā, un, izmantojot šo pieeju, var novērtēt izmaiņas ražošanas procesos pirms un pēc lauku saimniecībās ieviestajiem SEG emisiju mazināšanas pasākumiem. Tāpēc ražošanas faktoru izmantošanas izmainas tiek pieņemtas ar augšupejošu tendenci, nevis pieņemot, ka ievieš optimizāciju (samazinājumu) mēslojuma, augu aizsardzības līdzekḷu, darbaspēka, zemes un citiem faktoriem, kādu parasti izmanto aprēķinu metodei ,no augšas uz apakšu”.

Lai novērtētu katra ieviešamā pasākuma izmaksas, tika izmantoti statistikas dati, kuri atspoguḷo valsts vidējos lauku saimniecību izmaksu rādītājus. Aprēḳinos tiek iekḷauti rādītāji, kas attiecas tikai uz izmantoto ražošanas faktoru izmaksām, kurus izmanto saimniecībā. Šo rādītāju aprēḳināšanā tiek izmantoti LLKC apkopotie katras laukkopības kultūras audzēšanā izmantotie bruto seguma rādītāji un to skaitliskās vērtības (www.new.llkc.lv). Tas nozīmē, ka netiek izmantota LCA pieeja, kura aprēķinos ietver, piemēram, minerālmēslu ražošanā radītās SEG emisijas. Tāpat aprēḳinos netiek iekḷautas eko-agrosistēmu sniegtās pakalpojumu izmaksas un ieguvumi. Darba autors izmaksu - ieguvumu analīzē neiekḷauj KLP izmantoto pasākumu ieviešanas atbalsta mehānismu, kurš paredz, piemēram, papildu maksājumus par katru izmantoto LIZ ha zalināšanas prasību izpildei. Darba autors vadās no 
pieņēmuma, ka lauku saimniecībā pieņemtie lēmumi par SEG mazināšanas pasākuma ieviešanu būs saistīti ar paša lauksaimnieka uzvedības mainu, kas saistīti ar ražošanas resursu efektīvāku izmantošanu. Katra ieviešanas pasākuma efektivitāte ir atkarīga no darbībām, kuras veic SEG samazināšanas mērḳu sasniegšanai. Atsevišķu pasākumu ieviešana tikai vienai augkopības kultūraugu platībai nenodrošinās kopējā iespējamā samazinājuma potenciāla sasniegšanu. Tāpēc ir svarīgi saprast atsevišķo darbību kopsakarības. N, P un K minerālmēslojums ir būtiskākais faktors, kas nosaka iegūtās augkopības ražas lielumu un kvalitāti (Goulding K....2007).

Apkopojot iepriekš analizētos SEG emisiju samazināšanas pasākumus slāpekḷa aprites precīzai vadībai, darba autors aprēķināja emisiju samazināšanas potenciālu Latvijā audzētajiem kultūraugiem no viena LIZ ha, kas atspoguḷots 11. tabulā.

11.tabula

SEG samazinājuma potenciāls kultūraugu sējumiem gadā, $\mathrm{t} \mathrm{CO}_{2} \mathrm{eq} \mathrm{ha}^{-1}$

\begin{tabular}{|c|c|c|c|c|c|c|c|c|}
\hline \multirow{2}{*}{ 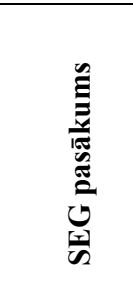 } & \multicolumn{7}{|c|}{$\begin{array}{c}\text { SEG samazinājuma potenciāls kultūraugu sējumiem, t } \\
\mathrm{CO}_{2} \mathrm{eq} \mathrm{ha}^{-1}\end{array}$} & \multirow{2}{*}{ 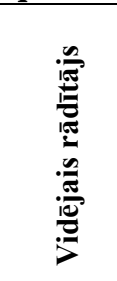 } \\
\hline & 预 & 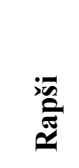 & 这 & 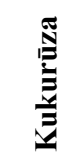 & $\begin{array}{l}\text { 题 } \\
\text { 空 } \\
\text { N }\end{array}$ & 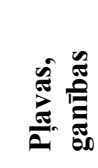 & 节 & \\
\hline SA 1 & 0.35 & 0.45 & 0.25 & 0.40 & 0.35 & 0.35 & 0.50 & 0.41 \\
\hline SA 2 & 0.20 & 0.20 & 0.20 & - & - & - & 0.20 & 0.20 \\
\hline SA 3 & 0.07 & - & - & - & 0.07 & 0.07 & - & 0.07 \\
\hline SA 4 & 0.17 & - & 0.27 & - & - & - & 0.36 & 0.27 \\
\hline SA 5 & 0.12 & 0.12 & 0.12 & 0.12 & 0.12 & 0.12 & 0.12 & 0.12 \\
\hline SA 6 & 0.04 & 0.04 & 0.04 & 0.04 & 0.04 & 0.04 & 0.04 & 0.04 \\
\hline $\begin{array}{l}\text { Platība } \\
\text { 2020. } \\
\text { gadā, } \\
\text { tūkst. ha }\end{array}$ & 759.6 & 106.4 & 31.4 & 29.27 & 400.27 & 747.12 & 8.1 & $\begin{array}{c}\begin{array}{c}\text { Kopā } \\
\text { platîba }\end{array} \\
2082.16\end{array}$ \\
\hline
\end{tabular}

Avots: autora aprēkini pēc Eory V., 2015; MacLeod M., 2015

Tieši N nepieciešamās normas izmantošana nodrošina atbilstošas ražas līmeņa sasniegšanu, un, kā rāda pētījumi, ja lauku saimniecībā netiek nodrošināta $\mathrm{N}$ izmantošanas precīza vadība, pieaug SEG emisijas. Lietotās $\mathrm{N}$ mēslošanas normas izmantošanas efektivitāti raksturo aprēḳinātā $\mathrm{N}$ bilance un slāpekḷa izmantošanas efektivitāte (NUE).

Potenciālais SEG emisiju samazinājums ir sasniedzams, ja:

$>$ tiek nodrošināta sabalansēta augu barības vielu bāze augsnē;

$>\mathrm{N}$ minerālmēslojums tiek izmantots atbilstoši faktiskajām kultūraugu vajadzībām;

> N minerālmēslu izmantošanu veic atbilstoši fotosintēzes procesiem augos, ievērojot augsnes temperatūras un mitruma rādītājus. 
Precīzās N minerālmēslojuma izmantošanas būtība ir noteikt pēc iespējas objektīvāk nepieciešamo mēslojuma devu katrā lauka nogabalā. Tas nozīmē, ka netiek izmantoti lauka vidējie augsnes auglības kvalitatîvie rādītāji, bet noteikti pēc iespējas mazākam kopējā lauka augsnes nogabalam. Galvenās priekšrocības: 1) ražas apjoma kāpinājums, nodrošinot precīzu nepieciešamo mēslojuma devu; 2) materiālo ieguldījumu samazinājums, neizmantojot mēslojumu lauka nogabalos ar pietiekamu barības bāzi un neveicot mēslojuma izmantošanu laikā, kad augos nenotiek fotosintēzes procesi; 3) ekonomiskais izdevīgums - paaugstinās produkcijas ražošanas rentabilitāte; 4) vides/ekologiskie ieguvumi - lauka nogabali ar pietiekamu barības bāzi netiek pārmēsloti un no mēslojuma, kuru augi nespēj uzṇemt, neveidojas $\mathrm{N}_{2} \mathrm{O}$ emisijas vidē.

Autora analizētajos piemēros MAC līknes konstruēšanai parasti izmanto kumulatīvo pieeju samazinājuma potenciāla noteikšanā, izvērtējot atsevišḳo pasākumu mijiedarbības ietekmi. Šādu pieeju izmanto arī darba autors, lai izvairītos no dubulta SEG iespējamā samazinājuma aprēḳināšanas. Atsevišķo pasākumu mazināšanas mijiedarbību izsaka kā koeficientu, kas raksturo mijiedarbības faktorus, un tā maksimālā vērtība ir 1(viens). Divu pasākumu mijiedarbībā iegūto kopējo SEG samazinājumu aprēķina pēc 9. formulas.

$$
S E_{k, i}=\left(S E_{k}+S E_{i}\right) * M E_{k-i},
$$

kur: $S E_{k, i}-k-t \bar{a}$ un $i-t \bar{a}$ pasākuma kopējais SEG emisiju samazinājums,

$S E_{k}-k$-tā pasākuma SEG emisiju samazinājums, $(\mathrm{k}=1,2, \ldots, 6)$,

$S E_{i}-i-t \bar{a}$ pasākuma SEG emisiju samazinājums, $(\mathrm{i}=1,2, \ldots, 6)$,

$M E_{k-i}-k-t \bar{a}$ un $i-t \bar{a}$ pasākuma SEG emisiju samazinājuma mijiedarbības koeficients.

Augkopības sektoram piemērojamo samazināšanas pasākumu mijiedarbības koeficientu vērtības tiek pieņemtas, vadoties pēc Skotijas zinātnieces V. Eory (2015) veiktajiem pieṇēmumiem un aprēḳiniem. Samazinājuma pasākuma SA6 (augsnes kalı̧ošana) pielietošana SEG emisijas palielina, bet kaļ̧⿻šana uzlabo $\mathrm{N}$ izmantošanas efektivitāti. Aprēḳinos tiek izmantots savstarpējās mijiedarbības koeficients, un attēlā 18 atsevišḳi SA6 samazinājuma efekts tiek iekḷauts pārējos samazinājuma pasākumos.

Kopējais SEG emisiju samazinājuma potenciāls tiks sasniegts, ja slāpekḷa mēslojuma izmantošanas precīzu vadību pielietos visos pasākuma ieviešanas etapos. Sākotnējie iegūtie pētījuma dati par augkopības saimniecībām liecina, ka svarīgākais pasākums ir augsnes agroḳīmisko analīžu veikšana. Optimāli un sabalansēti augsnes kvalitatīvie rādītāji nodrošina labu augu attīstību, garantētu barības elementu uzṇemšanu, ražas stabilitāti un ražības pieaugumu ar mazākām slāpekḷa minerālmēslojuma izmantošanas normām. Svarīgākais kvalitātes rādītājs eksportspējīgai kviešu produkcijai ir proteīna saturs. No graudu kvalitatīvajiem rādītājiem ir atkarīga to cena (pārtikas kvieši vid. EUR $156.13 \mathrm{t}$ un lopbarības kvieši EUR 131.21 t, Latraps. 2015). 
Graudu audzētājiem, kuri orientēti uz eksporta produkcijas ražošanu, jāspēj saražot kviešus ar proteīna saturu $12-13.5 \%$. Šādu proteīna saturu var panākt, izmantojot augstražīgas, intensīva tipa šķirnes un atbilstošas slāpekḷa mēslojuma normas. Svarīgi ievērot rekomendēto augu rotāciju laukā, jo, audzējot tauriņziežus, mikroorganismi piesaista atmosfēras $\mathrm{N}$ un pārvērš to amonjakā. Uz tauriņziežu saknēm mītošās gumiņbaktērijas spēj piesaistīt 100 $300 \mathrm{~kg} \mathrm{~N} \mathrm{ha}^{-1}$ gadā. Plānojot iegūt ziemas kviešu graudu ražu $6-7 \mathrm{t} \mathrm{ha}^{-1}$ ar proteīna saturu $12-13.5 \%$, augiem nepieciešams ap $180-220 \mathrm{~kg} \mathrm{~N} \mathrm{ha}^{-1}$. Ja augsnē organisko vielu saturs ir $2-3 \%$, orientējoties uz vidēji normālu veǵetācijas periodu, no augsnes ziemas kvieši izmantos līdz $120 \mathrm{~kg} \mathrm{~N}$. Vēl 80 $100 \mathrm{~kg}$ jānodrošina ar mēslošanas līdzekḷiem. Slāpekḷa izmantošanas koeficients no minerālmēsliem var būt vidēji $55-60 \%$, augsnē jāiestrādā ap $150-170 \mathrm{~kg} \mathrm{~N}$. Izmantojot precīzu N mēslošanas iestrādes vadību ar GPS, N izmantošanas koeficientu var būtiski paaugstināt.

18. attēls atspoguḷo kopējo SEG emisiju samazinājuma potenciālu un izmaksas, ieviešot augkopībā pasākumus, kuri nodrošinās $\mathrm{N}$ aprites precīzu vadību.

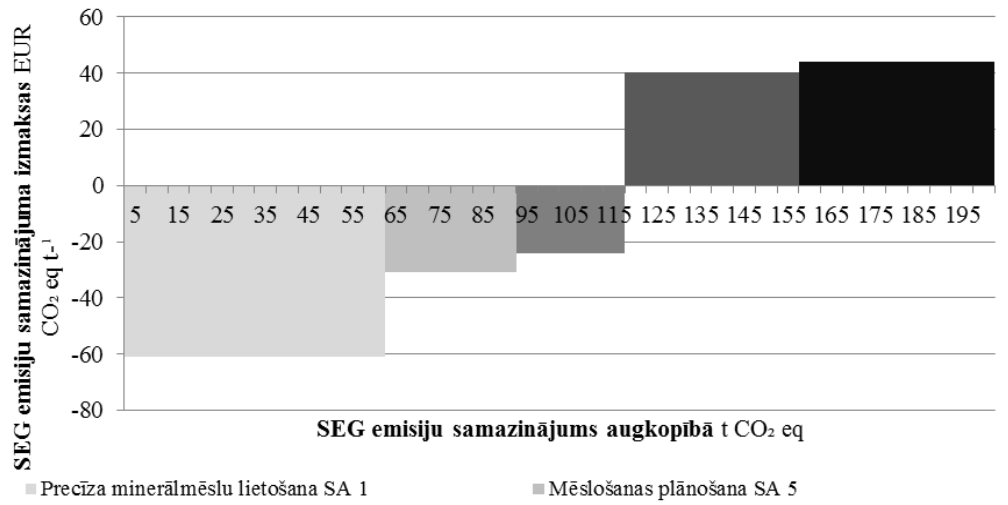

- Obligāta integrētās lauksaimniecibas ieviešana SA 2 - Tieša minerālmēslu iestrāde augsnē SA 3

- Nitrifikācijas inhibitoru pielietošana SA 4

Avots: autora konstrukcija

18.att. Slāpekḷa aprites precīzu vadību augkopībā nodrošinošo pasākumu SEG emisiju samazinājuma potenciāls un izmaksas 2015. - 2020. gadā.

SEG emisiju samazinājumu augkopībā un resursu izlietojuma samazinājumu jeb izmaksu pozitīvu ieguvumu saimniecībām nodrošina precīza $\mathrm{N}$ minerālmēslu lietošana, minerālmēslu izkliedes plānošana un obligātās integrētās lauksaimniecības sistēmas ieviešana. Savukārt tiešā minerālmēslu iestrāde augsnē un nitrifikācijas inhibitoru lietošanas pasākumi nodrošina SEG emisiju samazinājumu augkopībā, tomēr tie ir izmaksu negatīvi salīdzinoši 
augsto ieviešanas izmaksu dēl, jo veido negatīvu bruto segumu. Latvijā 2015. 2020.gadā, ieviešot slāpekḷa aprites precīzas vadības pasākumus augkopībā, ir iespējams samazināt SEG emisijas par $205 \mathrm{t} \mathrm{CO}_{2}$ eq.

\section{GALVENIE SECINĀJUMI}

1. Izmantoto dabas resursu (zemes) ilgtspējīga izmantošana un ekonomiskās izaugsmes un attīstības nodrošināšana ir iespējama, samazinot iespējamo negatīvo ietekmi uz ekonomisko, sociālo un dabas vidi, novērtējot to ar dabas kapitāla, finanšu kapitāla, ražošanas kapitāla un cilvēkkapitāla vērtības kvantitatīvo un kvalitatīvo rādītāju izmain̄ām.

2. Latvijā 2015. gadā bija zemākā lauksaimnieciskās ražošanas produktivitāte ES, 16.2 reizes atpaliekot no Nīderlandes, un tā bija 5 reizes zemāka nekā ES vidēji. Bruto nacionālais ienākums lauksaimniecībā uz 1 cilvēku Latvijā ir 2.6 reizes zemāks nekā Nīderlandē un 1.5 reizes zemāks nekā ES vidēji.

3. Lauksaimniecības izaugsmi Eiropā un pasaulē līdz 1999. gadam ir nodrošinājusi ražošanas intensifikācija, galvenokārt pieaugot minerālmēslu izmantošanai, kas palielināja ietekmi uz vidi, samazinot dabas kapitāla vērtību.

4. Lai noteiktu ekonomikas izaugsmes ietekmi uz dabas vidi, jāizmanto kopējās ekonomiskās vērtības (KEV) aprēķinu metode, ar kuru iespējams noteikt lauksaimniecībā izmantotās agro-ekosistēmas jeb dabas kapitāla vērtības izmainas.

5. Sākot ar 2000. gadu, lauksaimniecības izaugsme Eiropā un pasaulē galvenokārt tiek nodrošināta, ievērojot ilgtspējīgas attīstības principus, samazinot ražošanā radītos ārējos negatīvos efektus uz ekonomisko, sociālo un dabas vidi.

6. Bioekonomika ir lauksaimniecības, mežsaimniecības un akvakultūras uzkrāto bioresursu izmantošana ar mērki izveidot inovatīvu ekonomiku, kas rada zemas $\mathrm{CO}_{2}$ emisijas un veido līdzsvaru starp tādiem faktoriem kā ilgtspējīga lauksaimniecība un zivsaimniecība, nodrošinātība ar pārtiku un atjaunojamo biologisko resursu izmantošana rūpniecībā, radot darbavietas, tajā pašā laikā veicinot bioloǵisko daudzveidību un saudzējot vidi.

7. Lauksaimniecība ES ir politiski regulētākā tautsaimniecības nozare, un ES attīstības stratēgijā Eiropa 2020 ir izvirzīts mērkis samazināt SEG emisijas par $20 \%$, kā arī paaugstināt enerǵijas iegūšanu no AER par $20 \%$ un energoefektivitāti par 20\% salīdzinājumā ar 1990. gadu. Šo mērḳu sasniegšanā būtiska loma ir lauksaimniecībai.

8. ES KLP analīze 1960. - 2016. gadā rāda, ka no produktivitātes kāpināšanas (1960. gads) tā virzīta uz konkurētspējas (1980. gads), ilgtspējīgas lauksaimnieciskās ražošanas un vides saglabāšanas sinerğijas (1992. gads) un lauku vides politikas efektivitātes (2000. gads) paaugstināšanu. 
9. Atbilstoši konvencijai par klimata pārmaiņām, kas ir pieņemta 1992. gadā, un Kioto protokolam, kas ir ratificēts LR Saeimā, Latvijai uzlikts par pienākumu samazināt SEG emisijas ne-ETS sektoros līdz 2030. gadam salīdzinājumā ar 2005. gadu par 5\% atbilstoši 2016. gadā Parīzē panāktās vienošanās mērkịm.

10. Lauku saimniecību ekonomisko procesu izmaiņas raksturo to specializācija (samazinās jauktās specializācijas saimniecību skaits), ekonomiskā lieluma (pieaug ekonomiski lielo saimniecību skaits), apsaimniekotās lauksaimniecības zemes (pieaug aramzemes platības) un saimniekošanas modeḷa (pieaug biologiiskās saimniekošanas sistēmas saimniecību skaits) strukturālās izmainas.

11.2014. gadā Latvijā bija nepilni 82 tūkst. lauku saimniecību. To skaits salīdzinājumā ar 2005. gadu samazinājās par 39\%, bet salīdzinājumā ar 1996. gadu par 54\%. 2013. gadā, vērtējot pēc saimniecību specializācijas saražotās produkcijas vērtības, bija: tikai augkopībā 51\%, tikai lopkopībā $35 \%$ un jauktā specializācijā (augkopībā un lopkopībā) - 14\%. Vienas lauku saimniecības vidējā LIZ platība 2013. gadā pieaugusi par 48\% salīdzinājumā ar 2005. gadu un sasniedza 24 ha. Ekonomiski efektīvās saimniecības apsaimnieko vidēji 503 ha, bet mazās saimniecības 9.3 ha LIZ.

12. Lielākā ietekme uz SEG emisiju pieaugumu augkopībā Latvijā ir $\mathrm{N}_{2} \mathrm{O}$. Tā avoti ir slāpekḷa mēslojums (23\%) un izmantotās organiskās augsnes (54\%), kas veido 77\% SEG emisiju no kopējām augsnes emisijām Latvijā 2014. gadā. Šīs emisijas no 2005. gada līdz 2014. gadam palielinājās par 83\%, atstājot ietekmi uz kopējo SEG emisiju palielinājumu.

13. Slāpekḷa minerālmēslu izmantošana ir būtiska, lai iesaistìtu augkopības produkcijas ražošanā līdz šim neizmantotās LIZ platības. Autora veiktā regresijas analīze apstiprina, ka slāpekḷa minerālmēslu izmantošanas pieaugums ir cieši saistīts ar augkopības produkcijas izlaidi, kā arī ar SEG pieaugumu lauksaimniecībā, palielinot negatīvo ietekmi uz dabas vidi.

14. Lai nodrošinātu lauksaimniecības ilgtspējīgu attīstību, kas balstās ne tikai uz izaugsmi, jāievēro četri galvenie kritēriji, kurus raksturo rādītāji, kas: 1) identificē, novērtē un raksturo sistēmas stāvokli; 2) prognozē sistēmas attīstību un mērķa sasniegšanu; 3) informē par veiktās darbības efektivitāti; 4) informē sabiedrības sociālās grupas. Augkopības ilgtspējīgas intensifikācijas novērtēšanu veic, izmantojot četru soḷu metodiku, kuru veido: (1) darbības cēloṇu identifikācija un definēšana; (2) atbilstošu ilgtspējības rādītāju definēšana; (3) ilgtspējīgas intensifikācijas indeksu noteikšana; (4) ietekmes uz ilgtspējīgu attīstību novērtēšana.

15. Augkopības izaugsmes 2005. - 2015. gadā un SEG emisiju indeksu aprēķini rāda, ka analizētajos gados noticis augkopības produkcijas ražošanas ievērojams pieaugums, tomēr tā panākta, neievērojot augkopības ilgtspējas nosacījumus, sevišḳi ekonomiski lielajās saimniecībās. 
16. Lauksaimniecības SEG emisijas Latvijā 2005. - 2015. gadā un izmaiṇu prognoze līdz 2030. gadam uzrāda pieauguma tempu, kurš pārsniedz neETS sektoram atlauto $+17 \%$ palielinājumu par $39 \%$.

17. Izmantojot MAC līknes konstruēšanas pieeju "no apakšas uz augšu", tiek veikts katra ieviešamā pasākuma bruto seguma novērtējums, kurš tiek salīdzināts ar bāzes scenārija (LLKC bruto seguma dati) izmaksām. Savukārt robežsamazinājuma izmaksu līkne ḷauj novērtēt atsevišķu SEG samazinošo pasākumu ekonomisko izdevīgumu, sniedz informāciju, kuru pasākumu ieviešana ir iespējama pie noteiktiem nosacījumiem.

18. SEG samazinājuma potenciāls kultūraugu sējumiem gadā, ieviešot pasākumu „slāpekḷa aprites precīza vadība", ir $0.45 \mathrm{t} \mathrm{CO}_{2}$ eq ha ${ }^{-1}$. Izmēgeinājuma saimniecībā ar precīzu $N$ vadību tiek sasniegta ziemas kviešu ražība 6.4 t.ha $^{-1}$, izmantojot $82 \mathrm{~kg} \mathrm{~N} \mathrm{ha}^{-1}$. Saimniecībā bez precīzas $\mathrm{N}$ vadības ziemas kviešu ražǐba $6.5 \mathrm{t}$ ha $^{-1}$, izmantojot $188 \mathrm{~kg} \mathrm{~N} \mathrm{ha}^{-1}$. Tiešo un netiešo emisiju samazinājums no $\mathrm{N}$ minerālmēslojuma ietaupījuma ir $1696 \mathrm{~kg} \mathrm{CO}_{2} \mathrm{eq}$. $\mathrm{ha}^{-1}$.

19. SEG emisiju samazināšanas pasākumi tika vērtēti pēc izmaksu un ieguvumu aprēķinu metodes. Latvijā 2015. - 2020. gadā, ieviešot slāpekḷa aprites precīzas vadības pasākumus augkopībā, ir iespējams samazināt SEG emisijas par $205 \mathrm{t} \mathrm{CO}_{2}$ eq.

\section{PROBLĒMAS un PRIEKŠLIKUMI to risināšanai}

Latvijas lauksaimniecības (augkopības) ilgtspējīgu attīstību kavē problēmas, kuru risināšanai autors ir izstrādājis vairākus priekšlikumus.

1. problēma. Praktiskos un teorētiskos ar lauksaimniecības attīstību un izaugsmi saistītos pētījumos plaši tiek lietots termins ,ilgtspējīga attīstība”, taču nav precīzi definēts termina „lauksaimniecības ilgtspējīga attīstība” pielietojuma teorētiskais un praktiskais skaidrojums.

\section{Priekšlikumi}

Turpmākajos praktiskajos un teorētiskajos pētījumos lietderīgi izmantot promocijas darba autora definīciju: „lauksaimniecības ilgtspējīga attīstība” ir virzība uz konverǵences līdzsvara stāvokli, kas realizējas kā līdzsvarota dabas, ekonomiskās un sociālās vides attīstība, kuru nosaka dabas kapitāla, finanšu kapitāla, ražošanas kapitāla un cilvēkkapitāla vērtības pieaugums lauksaimniecībā.

2. problēma. Lauksaimniecības ilgtspējīgu attīstību ES nodrošina lauksaimniecības un vides politikas sinerǵija, kuras īstenošana balstās uz pieņemtajiem normatīvajiem aktiem. Latvijā ir nepieciešama normatīvo aktu pilnveidošana, lai nodrošinātu ilgtspējīgu lauksaimniecības attīstību.

\section{Priekšlikumi}

Lauksaimniecības, vides un reǵionālās pārvaldības institucionālajām struktūrām, kā arī sociālajiem partneriem ieteicams sekmēt sadarbības un 
sinergijas procesus starp visiem lauksaimniecības ražošanas un vides aizsardzības sistēmās iesaistītajiem dalībniekiem. Latvijas ilgtspējīgas attīstības rādītājos iekḷaut lauksaimniecības SEG emisiju intensitātes novērtējuma indikatoru un Latvijas Lauku attīstības plānā nākamajam plānošanas periodam paredzēt atbalstu pasākumu ieviešanai SEG emisiju intensitātes samazināšanai.

3. problēma. Latvijas lauksaimniecības (augkopības) attīstībai un izaugsmei ir pieejami neizmantoti aptuveni 400 tūkst. ha lauksaimniecībā izmantojamās zemes, taču šo platību iesaistīšana ražošanā veicinās būtisku SEG emisiju pieaugumu.

\section{Priekšlikumi}

Latvijas Lauksaimniecības universitātei

Izstrādāt ekonomiski un sociāli pamatotu sistēmu, nosakot valsts institūcijām veicamos uzdevumus, lai līdz 2020. gadam 275 tūkst. ha LIZ tiktu iekḷauta ražošanā.

\section{LR Zemkopības ministrijai}

Sagatavot valsts programmu 2020. gadam, kurā paredzēt, ka lauksaimniecībā izmantojamā zeme pieaugs par 275 tūkst. ha, nodrošinot vides ilgtspējas mērķus un SEG emisiju rādītājus.

4. problēma. Augkopības ilgtspējīga intensifikācija samazina ietekmi uz dabas, sociālo un ekonomisko vidi, tomēr pastāv liela diference starp dažāda ekonomiskā lieluma lauku saimniecībām.

\section{Priekšlikumi}

Lauksaimniecības pārvaldības institucionālajām struktūrām sagatavot rīcības programmu ilgtspējīgas intensifikācijas principu ieviešanai lauku saimniecībās atbilstoši to ekonomiskajam lielumam. Lauku saimniecību attīstības novērtēšanai būtu lietderīgi izmantot darba autora izstrādāto ilgtspējīgas intensifikācijas aprēķināšanas metodoloǵiju. Lauksaimniecības SUDAT datu bāzi papildināt ar dabas kapitāla izmainu rādītājiem ilgtspējīgas intensifikācijas novērtējuma uzlabošanai.

5. problēma. SEG samazinošo pasākumu ieviešana augkopībā nodrošinās dabas vides saglabāšanu un ekonomiskos ieguvumus lauku saimniecībām, bet pašreizējā situācijā ir nepietiekama dabas kapitāla izmaiņu sasaiste ar lauku saimniecību finanšu kapitāla izmaiņām.

\section{Priekšlikumi}

Lauksaimniecības pārvaldības institucionālajām struktūrām ieviest praktiskā izmantošanā lauku saimniecībās SEG emisiju uzskaites, aprēḳinu un analīzes rīku, kurš sasaistīts ar LAD sistēmu. Izvērtējot KLP atbalsta maksājumu piešķiršanu lauku saimniecībām, tajā ietvert SEG emisiju intensitāti uz saražotās produkcijas vienību. 


\section{INFORMATION ON RESEARCH PAPERS AND SCIENTIFIC RESEARCH WORK}

\section{The research results were reported in 16 research papers published in}

scientific publications, of which 7 were indexed by the SCOPUS database and 7 by the Web of Science database:

1. Popluga D., Naglis-Liepa K., Lenerts A., Rivza P. (2017) Marginal abatement cost curve for assessing mitigation potential of Latvian agricultural greenhouse gas emissions: case study of crop sector. In: Ecology, Economics, Education and Legislation: Proceedings of the International Multidisciplinary Scientific Geoconference SGEM 2017. Vol. 17, pp. 511-518, ISSN 1314-2704. (Indexed by Scopus, EBSCOhost Academic Search Complete).

2. Lenerts A., Popluga D., Schulte R.P.O., Pilvere I. (2017) Sustainability assessment of agricultural production: case study of Latvian crop sector. In: Engineering for Rural Development: Proceedings of the $16^{\text {th }}$ International Scientific Conference. Jelgava: LLU, Vol.16, pp. 1312-1320, ISSN 16915976. (Indexed by Scopus, Crossref).

3. Lenerts A. Popluga D., Rivza P. (2017) Selection of greenhouse gas emission-reducing measures with analytical hierarchy process approach: a case study from Latvian crop production sector. In: Economics Science for Rural Development: Proceedings of the International Scientific Conference, Nr.44 (Bioeconomy). Jelgava: LLU, pp. 267-273, ISSN 1691-3078. (Indexed by Web of Science, EBSCOhost Academic Search Complete).

4. Kreišmane D., Naglis-Liepa K., Popluga D., Lenerts A., Rivža P. (2016) Liming effect of nitrogen use efficiency and nitrogen oxide emissions in crop farming. In: Research for Rural Development 2016, 18-20 May: Proceedings of the Annual 22 ${ }^{\text {nd }}$ International Scientific Conference, Jelgava, Latvia, 2016 / Latvia University of Agriculture. Jelgava, 2016, Vol. 1, pp. 30-36, ISSN 1691-4031. (Indexed by Web of Science, EBSCOhost Academic Search Complete).

5. Popluga D., Kreišmane D., Naglis-Liepa K., Lenerts A., Rivža P. (2016) Fertilisation planning as effective tool for balanced economic and environmental benefits in crop farming. In: Research for Rural Development 2016, 18-20 May: Proceedings of the Annual $22^{\text {nd }}$ International Scientific Conference, Jelgava, Latvia, 2016 / Latvia University of Agriculture. Jelgava, 2016, Vol. 1, pp. 23-29, ISSN 16914031. (Indexed by Web of Science, EBSCOhost Academic Search Complete).

6. Lenerts A., Popluga D., Naglis-Liepa K., Rivža P. (2016) Fertilizer use efficiency impact on GHG emissions in the Latvian crop sector. In: Biosystems Engineering 2016. 7th International Scientific Conference Tartu, Estonia, Journal Agronomy Research, pp. 123-133. ISSN 1406- 
894X. (Indexed by Scopus, Web of Science BIOSIS Citation Index, EBSCOhost Academic Search Complete, CAB Abstracts).

7. Lenerts A., Berzins G., Popluga D. (2016) Nitrogen fertilizer use efficiency and GHG emissions in the Latvian grain sector. In: Engineering for Rural Development: Proceedings of the $15^{\text {th }}$ International Scientific Conference. Jelgava: LLU, pp. 224 - 229. ISSN 1691-5976. (Indexed by Scopus, Web of Science, EBSCOhost Academic Search Complete, CABI).

8. Lēnerts A. (2015) Agriculture in Latvia: economic activity and GHG emissions. In: Scientific and practical conference Balanced Agriculture. Jelgava: LLU, pp. 19-20. ISBN 9789984481760. (Indexed by AGRIS, CAB Abstracts).

9. Lenerts A. (2015) Development of Sustainable Intensification Evaluation Methodology for Farmlands in Latvia. In: Economics Science for Rural Development: Proceedings of the International Scientific Conference, Nr. 37 (Bioeconomy). Jelgava: LLU, pp. 160-171. ISSN 1691-3078. (Indexed by Web of Science, EBSCOhost Academic Search Complete).

10. Pilvere I., Lenerts A. (2015) Agricultural GHG emission and mitigation measures in Latvia. In: Engineering for Rural Development: Proceedings of the $14^{\text {th }}$ International Scientific Conference. Jelgava: LLU, pp. $571-576$. ISSN 1691-5976. (Indexed by Scopus, Web of Science, EBSCOhost Academic Search Complete, AGRIS).

11. Lenerts A., Popluga D. (2015) Facilitate Calculations of GHG Emissions in Latvian Agriculture at Farm Level. In: Ecology, Economics, Education and Legislation: Proceedings of the International Multidisciplinary Scientific Geoconference SGEM 2015. Volume III pp. 287-294. ISSN 1314-2704. (Indexed by Scopus, Web of Science).

12. Popluga D., Naglis-Liepa K., Lenerts A. (2015) Latvia's Progress Towards Agricultural GHG Mitigation. In: Nordic View to Sustainable Rural Development. Proceedings of the NJF $25^{\text {th }}$ Congress, pp. 265-270. ISBN 978-9934-14-549-0. (Indexed by Web of Science, CAB Abstracts, EBSCOhost Academic Search Complete).

13. Lenerts A., Strikis V. (2013) Bio-economy and a sustainable market for biofuels. In: Ecology, Economics, Education and Legislation: Proceedings of the International Multidisciplinary Scientific Geoconference SGEM 2013. Volume II pp. 49-56. ISSN 134-2704. (Indexed by Scopus, Web of Science).

14. Lenerts A. (2013) Sustainable Use of Bio-resources of Agricultural Origin: The Basis of Bioeconomy in Latvia. In: Rural Development 2013: Innovations and Sustainability: Proceedings of the Annual $6^{\text {th }}$ International Scientific Conference. Volume 6, Book 1 pp. 209-214.ISSN 2345-0916. (Indexed by Web of Science, EBSCOhost Academic Search Complete).

15. Lenerts A., Pilvere I. (2012) Role of Land Resources in the Development of the Market of Renewable Energy Sources of Agricultural Origin in Latvia. In: Economic Science for Rural Development: Proceedings of the 
International Scientific Conference. No. 29: Rural Business and Finance, pp. 73-79. 1691-3078. (Indexed by Web of Science, EBSCOhost Academic Search Complete, EBSCOhost Central and Eastern European Academic Source, AGRIS).

16. Strīkis V., Kalniņš A., Lenerts A. (2012) Possibilities for renewable energy production on farms. In: Renewable Energy and Energy Efficiency: Proceedings of the International Scientific Conference. No.1: Economic and legislative aspects of the renewable energy production, pp. 231-234. 9789984-48-070-1. (Indexed by Web of Science, CAB Abstracts, AGRIS).

The research results were presented in 13 international scientific conferences:

1. Lenerts A. Sustainability assessment of agricultural production: case study of Latvian crop sector. $16^{\text {th }}$ International Scientific Conference: Engineering for Rural Development. Jelgava, LLU (Latvia), 24 May 2017.

2. Lenerts A. How sustainable is Latvia's agriculture? $16^{\text {th }}$ International Scientific Conference: Economic Science for Rural Development. Jelgava, LLU (Latvia), 28 April 2017.

3. Lenerts A. Assessment of GHG Emission Reduction Measures Appropriate for Latvia. Scientific and Practical Conference on Balanced Agriculture: Harmonious Agriculture. Jelgava, LLU (Latvia), 26 February 2016.

4. Lenerts A. Nitrogen fertilizer use efficiency and GHG emissions in the Latvian grain sector. $15^{\text {th }}$ International Scientific Conference: Engineering for Rural Development. Jelgava, LLU (Latvia), 26 May 2016.

5. Lenerts A. Development of Sustainable Intensification Evaluation Methodology for Farmlands in Latvia. $16^{\text {th }}$ International Scientific Conference: Economic Science for Rural Development. Jelgava, LLU (Latvia), 23 April 2015.

6. Lenerts A. Agricultural GHG emission and mitigation measures in Latvia. $14^{\text {th }}$ International Scientific Conference: Engineering for Rural Development. Jelgava, LLU (Latvia), 21 May 2015.

7. Lenerts A. Facilitate Calculations of GHG Emissions in Latvian Agriculture at Farm Level. $15^{\text {th }}$ International Multidisciplinary Scientific GeoConference SGEM: Ecology, Economics, Education and Legislation. Albena, (Bulgaria), 19 June 2015.

8. Lenerts A. Agriculture in Latvia: Economic Activity and GHG Emissions. Scientific and Practical Conference on Balanced Agriculture: Harmonious Agriculture. Jelgava, LLU (Latvia), 20 February 2015.

9. Lenerts A. Sustainable Use of Bio-resources of Agricultural Origin: the Basis of Bioeconomy in Latvia. International Scientific Conference: Rural Development 2013: Innovations and Sustainability. Kaunas, ASU (Lithuania), 28 November 2013.

10. Lenerts A. Challenges of Bioeconomy. $6^{\text {th }}$ Jonas Pranas Aleksa International Scientific Conference: Contemporary Rural Vision. Siauliai, Siauliai University (Lithuania), 27 September 2013. 
11. Lenerts A. Bio-economy and a sustainable market for biofuels. $13^{\text {th }}$ International Multidisciplinary Scientific GeoConference SGEM: Ecology, Economics, Education and Legislation. Albena, (Bulgaria), 22 June 2013.

12. Lenerts A. Role of Land Resources in the Development of the Market of Renewable Energy Sources of Agricultural Origin in Latvia. International Scientific Conference: Economic Science for Rural Development. Jelgava, LLU (Latvia), 27 April 2012.

13. Lenerts A. Possibilities for renewable energy production on farms. International Scientific Conference: Renewable energy and energy efficiency. Jelgava, LLU (Latvia), 27 May 2012.

\section{Public activities in relation to the doctoral dissertation:}

1. A study course Bioeconomics was designed and implemented in the academic bachelor study programme Economics at the LLU Faculty of Economics and Social Development.

2. Participation in an LLU research study Economically Efficient, Sustainable and Productive Use of Land for the Production of Agricultural and Forestry Products.

3. The Sustainable Development Commission of the $12^{\text {th }}$ Saeima of the Republic of Latvia was familiarised with the research findings on 13 October 2017.

4. The author took part in the national research programme project Value and Dynamic of Latvia's Ecosystems under Changing Climate (EVIDEnT), No. 2014/VPP2014-2017 as a researcher in 2014-2018.

\section{INTRODUCTION}

Nowadays, under the market economy, the development of the national economy, including the agricultural sector and rural areas as a whole, is affected by a number of factors and the interests of various market actors. A solution has to be found on: how to meet the growing demand for food; how to reduce the use of fossil resources; how to increase the use of renewable sources; how to limit the negative impacts of economic activity on the economic, social and environmental environments.

Fossil resources in the territory of Latvia are available only theoretically, yet the geographical location and climate of the country make land resources available in the country particularly valuable for the production of diverse products. According to the Central Statistical Bureau of Latvia (CSB) (CSB, 2015), totally $2.2 \mathrm{mln}$. ha of agricultural land was available for agricultural production, yet only $1.8 \mathrm{mln}$. represented the utilised agricultural area (UAA) in 2015, according to the Rural Support Service (RSS). It is important to exploit the entire UAA in order to contribute to economic growth in Latvia. Opportunities for the use of the mentioned resources in the context of economic 
growth in agricultural industries were extensively researched by a number of Latvian scientists (Boruks A., 1982; Špoǵis K., 2007; Strīkis V., 2013; Dobele A., 2005; Auziņš A., 2013; Pilvere I., 2015; Nipers A., 2015). Besides, several strategic policy documents and guidelines stress the sustainability of the resources or the use of them for sustainable economic purposes.

The Sustainable Development Strategy of Latvia until 2030 (Latvijas ilgtspejīigas..., 2010) states that the natural capital of Latvia is in relatively good condition, yet it is exploited and managed insufficiently. The National Development Plan of Latvia (NDP, 2012) has set an indicative target to exploit at least $2 \mathrm{mln}$. ha of agricultural land for agricultural production by 2020 . A similar indicative target is set by the Rural Development Programme of Latvia 2014-2020 (RDP, 2014). The economic efficiency of CAP funding used in Latvia was researched by a number of authors (Pilvere I., 2012; Miglavs A., Vēveris A., 2011; Upīte I., 2012; Tetere V., 2012). For an analysis of problems in and challenges for agricultural sustainability in relation to a balance between social and economic factors, an essential turning point in developmental processes in the agriculture and rural areas of Latvia was the EU strategy "Innovating for Sustainable Growth: a Bioeconomy for Europe" adopted in 2012. Innovative, competitive and resource-efficient production that can meet the demand for food and renewable bioresources without making additional impacts on the economic, social and natural environments is necessary to follow the key principles of a bioeconomy (Inovācijas ilgtspējīgai izaugsmei..., 2012). A balance between production intensification and meeting the principles of sustainability has to be found in order to implement the strategy. Agricultural production expansion has to be based on the principles of sustainable intensification. The problems of sustainable agricultural intensification have been researched by a number of foreign scientists (Pretty J., 1997; David S., 1989; Webster P., 1999; van Calker K., 2007). Some scientists (Dzene S., 2014) have focused on sustainability problems with regard to Latvian agriculture, which does not always lead to an increase in agricultural production. In the nearest future, one of the most complicated objectives for farmers and scientists is to find convergent or balanced development opportunities for the natural, economic and social environments in the situation of growth of intensive agricultural production, as greenhouse gas (GHG) impacts on the environment continue increasing. Historically, due to objective reasons, with agricultural output decreasing after 1990, agricultural GHG emissions also decreased by $74 \%$, totalling $2175 \mathrm{Gg} \mathrm{CO}_{2}$ eq in 2005 (Latvia's National, 2015). However, the situation is going to change radically after 2020 because in accordance with the new indicative target (Decision No. 406, 2009) Latvia has to reduce its GHG emissions in the sectors (including agriculture) that are not included in the EU emission trade system (non-ETS sectors) by 2030 so that the emissions do not exceed the 2005 level (agricultural emissions in 2014 totalled $2424 \mathrm{Gg} \mathrm{CO}_{2}$ eq) (Decision No. 406, 2009). 
For this reason, increasing the UAA in Latvia, achieving the GHG emission reduction target in the non-ETS sectors as well as the increasing GHG emissions from agricultural activity and the international commitments require seeking opportunities to balance all these processes, while also ensuring:

an increase in the UAA - it is necessary to find ways how to use the increased UAA only for the production of competitive agricultural products;

$>$ a decrease in GHG emissions - to develop agricultural production technologies and introduce GHG emission reduction measures that contribute to the economic sustainability of agricultural enterprises;

$>$ meeting the international commitments - to reduce GHG emissions from agriculture - may not decrease economic activity and also economic development in rural territories in Latvia.

Scientists in the EU and elsewhere (Moran D., 2011; Eory V., 2015; Schulte R., 2012; Pellerin S., 2013) have extensively researched agricultural and environmental sustainability through the implementation of emission reduction measures, assessing their impacts on the natural and social environments and the economic performance of agricultural enterprises. There are quite a few such research investigations; for this reason, the author chose this topic in order to perform a detailed assessment of balanced or convergent development opportunities for agricultural growth and the reduction of crop production impacts on the environment in Latvia.

Such an assessment allowed the author put forward a hypothesis sustainable intensification in crop farming results in GHG emissions and contributes to agricultural development. Taking into account the research limitations, the research object is agricultural development in Latvia, while the research subject is the reduction of GHG emissions from crop production.

Based on the hypothesis, the research object and the research subject, the following research aim was set - to examine opportunities for sustainable agricultural development in Latvia if introducing potential GHG emission reduction measures in crop production.

To achieve the aim, the following specific research tasks were set:

$>$ to examine the theoretical aspects of sustainable agricultural development;

$>$ to analyse the agricultural and environmental policies and the legal and institutional framework for agriculture and the environment;

$>$ to develop a methodology for sustainable intensification calculation and perform an assessment of crop production development;

$>$ to assess the impacts of GHG emission reduction measures on the natural and economic environments in Latvia.

In view of the fact that economics is a real, empirical science based on facts, the data were acquired from publicly available statistical databases and processed by means of adequate data and information processing methods. Several research methods were employed to perform each research task, which were appropriate for researching each problem: 
$>$ general research methods - analysis and synthesis, monographic, descriptive, induction and deduction - were used to analyse the aspects of economic development and agricultural growth and the policy, legal and institutional frameworks aimed at reducing the externalities of agricultural production;

$>$ analysis and synthesis as well as statistical analysis - statistical processing, data generalisation, time series, correlation and regression analysis - were applied to identify the factors affecting agricultural production development and related GHG emissions;

$>$ statistical analysis (statistical processing, grouping, correlation analysis) as well as analysis and synthesis were employed to analyse trends in sustainable agricultural intensification;

$>$ general research methods - analysis, synthesis, induction and deduction -, expert evaluation (quantitative and qualitative) and hierarchy analysis were applied to perform an economic and an environmental assessment of the impacts of GHG emission reduction measures for crop farming.

To achieve the aim and perform the research tasks, the following information sources were used:

$>$ international documents, legal acts of the EU, the European Commission and the Republic of Latvia (LV), national strategic and policy documents;

$>$ Eurostat, the Central Statistical Bureau of Latvia (CSB) and other databases;

$>$ specific scientific literature, relevant research studies and research papers in scientific databases related to the topic of the dissertation;

$>$ expert evaluation results.

\section{Research limitations}

Economic activity in rural areas is an essential factor for economic growth in the country. Agricultural growth is affected by such significant factors as the demand for and supply of agricultural products, availability of resources, prices, technologies used, and negative externalities caused by farming in the form of emissions. The dissertation cannot assess the effects of all the factors, therefore it focuses on agricultural growth aspects in the context of negative impacts created by greenhouse gas emissions from crop production. Such a choice was determined by three essential considerations: crop farming produces the largest quantity of agricultural products in Latvia and it exploits the key natural resource of Latvia - land; after 2020, agricultural GHG emissions have to be considerably reduced; before 2020 , the area for agricultural production has to be increased.

\section{Research novelty and scientific relevance}

$>$ theoretical and empirical research resulted in a multifaceted assessment of the sustainability of the economic, social and natural environments and technologies for crop farming in Latvia;

$>$ key trends in agricultural development were identified by focusing on interdisciplinary research studies on balanced crop production development; 
a relevant research study was done on a little researched problem of agricultural economics - crop production growth under sustainable intensification -, and a methodology for assessment of sustainable intensification was designed;

$>$ cost-benefit analysis calculations were performed for GHG emission reduction measures.

\section{Economic significance of the research}

$>$ the present research contributes to the theoretical framework of agriculture in relation to crop production under sustainable intensification;

$>$ the research findings could be used for designing a crop production development programme, as well as they are useful in decision-making for agricultural holdings.

\section{Theses to be defended}

1. Agricultural development is ensured by a balanced increase in human, natural, financial and manufactured capital.

2. Sustainable agricultural development is ensured by a synergy between agricultural and environmental policies, the achievement of which is based on the legal acts passed and the institutional system created;

3. Latvian agriculture, crop farming in particular, develops dynamically and contributes to the production of GHG emissions.

4. Sustainable crop production intensification reduces negative impacts on the environment, thereby ensuring balanced development of the economic, social and natural environments.

5. The introduction of GHG emission reduction measures in crop farming ensures the preservation of the natural environment and economic benefits from sustainable agricultural development.

\section{THEORETICAL ASPECTS OF AGRICULTURAL SUSTAINABLE DEVELOPMENT}

The chapter is 27 pages long and includes 3 tables and 9 figures.

The chapter discusses explanations of the concept of sustainable agriculture. It gives an enhanced definition for sustainable agricultural development and characterises the position and role of a bioeconomy in sustainable agricultural development.

The chapter puts forward a thesis: agricultural development is ensured by a balanced increase in human, natural, financial and manufactured capital.

\subsection{Theoretical explanation of the terms economic development and growth}

According to economic growth theory, the stages of development that have made a considerable effect on agricultural growth and development are as follows: 
The classical growth theory or economic liberalism $\left(18^{\text {th }}\right.$ and $19^{\text {th }}$ centuries) - the founders of the theory were A.Smith, D.Ricardo, A.Marshal, A.C.Pigou and others, who believed that an economy could function in the best way on its own, and the economic processes were controlled by the "invisible hand", and government did not have to intervene. The ideas of the mentioned economists were popular up to the 1930s (Treisijs M., 1996).

Keynesian economics or Keynesianism (1930s) - the founder was J.M. Keynes. The theory was based on an idea that short-term interventions by the government in economic processes through investments and prudent regulation of aggregate demand foster growth during an economic crisis. The EU Common Agricultural Policy is the most remarkable result of this theory. This theory was successfully implemented during the first independence period of Latvia (Bērziņšs-Valdess R. et al., 1938). Later on, the theory was enhanced by representatives of neo-Keynesianism: F. Modigliani, J. Tobin and G. Mankiw.

Monetarism (neoliberalism) (1960s) - the founder was M. Friedman who believed that the role of government had to be reduced. A dominant idea was that economic growth depended on tight monetary policies. The result of this theory was economic globalisation and an unlimited flow of financial capital, which was considered to be the key factor of economic growth that contributed to faster development of the agricultural industry. However, the key objective equal prosperity across all the regions of the world - was not achieved.

In the middle of the $20^{\text {th }}$ century, neoliberalism theoreticians split into two schools of economic thought, and particularly the representatives of the German or Freiburg School, W. Eucken, F. Böhm and W. Röpke, established the Ordo-liberal School that later influenced agricultural development in Europe (Eise S., 2012).

The first economic growth models that were based on the Cobb-Douglas production function proposed by C.W. Cobb and P.H. Douglas were developed during this period; the function was later enhanced by Nobel Prize winner Robert Solow. Both Keynesianism and monetarism view growth as exogenous, as the theories refer to the necessity for external assistance, e.g. in the form of investment attracted.

Endogenous growth theory (1990s). The authors of this theory were M. Todoro, K. Arous, P. Romer and others who proved that long-term growth was possible at a stationary situation in the economy if such factors as technological progress, increasing returns and human capital development are employed.

The concept of convergence was developed in search of solutions to balanced application of the exogenous and endogenous growth theories in a real economy as well as to avoid imperfections in economic growth.

Alternative Economic Growth Theories (1970s). Two diverse viewpoints emerged after developing alternative economic growth scenarios. Some scientists (Georgescu-Roegen N., 1971; Meadows D.H., 1972) defined their idea that increasing economic activity (production and consumption) results in the consumption of more resources, which, in its turn, creates more by-products 
and waste and, consequently, environmental pollution is produced, thereby decreasing the life quality and prosperity (Daly H., 1991). A work by Rome Club scientists, Limits to Growth, proves that the inclination for economic growth has to be stopped in order to maintain economic activity at all, as it is going to unavoidably decrease because of the depletion of resources and the environment. In the opinion of the author, such an approach would make problems in rural areas more acute. In their models, the developers of alternative growth theories used a hypothesis put forward by S. Kuznets - at the initial stage of economic growth, the environmental impact is going to increase, yet after the prosperity of the population has reached a certain level, the environmental impact is going to decrease (Rothmans S., 1998). The author of the dissertation believes that measures aimed at enhancing the natural, economic and social environments, which are introduced in an agricultural production system, lead to higher productivity of the factors of production and foster agricultural growth and development in the context of environmental impacts. It has been proved that the economic benefits from a GHG emission reduction are larger than the costs of the reduction (Dudek D., 2002).

In the scientific literature, authors use the terms economic development and economic growth. Both terms are used to refer to various and diverse changes in the economy. It is important to understand differences between the terms. An economic dictionary (Rutherford D. et al., 2002) gives two explanations to the term economic development:

$>$ economic transition from agricultural production that uses simple technologies to industrial production and a broad assortment of services, which involves the use of modern technologies;

$>$ cumulative income increases per inhabitant, which is accompanied by structural and institutional changes.

Based on the examination of economic thought, the dissertation suggests the following sustainable agricultural development definition.

Sustainable agricultural development is convergence towards a balanced situation that takes the form of balanced development of the natural, economic and social environments, which is determined by increases in the value of natural, financial, manufactured and human capital in agriculture.

After analysing the economic growth theories, the author of the dissertation concludes that in a situation with several competing growth models, a common feature of the models is to encompass negative externalities, which are measured by means of qualitative indicators of the natural environment. In designing economic development models for agricultural production, it is important to comprehend the behaviours of all the actors engaged in this process, which are aimed at achieving their goals. The probability of an ideal situation, in which an unregulated free market (including agriculture) is able to overcome all contradictions existing in the market economy, is only theoretical. This means that an endogenous growth model for the agriculture of Latvia has 
to be developed; the model has to define options for convergence or balanced development aimed at agricultural growth and reducing environmental impacts.

\subsection{Exploitation of natural capital to ensure economic development}

After examining the economic growth theories, the author of the dissertation concludes that the perception of the resources used in production has changed at macroeconomic (global) level. Authors use the term limited resources when refer to economics as a science. An objective to be achieved in the nearest future is to assess the value of natural capital (natural and environmental resources) and integrate it into the unified market system. Scientists I. Sundar (2012), J. Pretty (2011), G. Akerlof (1970), N. GeorgescuRoegen (1971) and others share the opinion that an increase in the value of natural capital is the basis for economic development and growth in the prosperity of individuals.

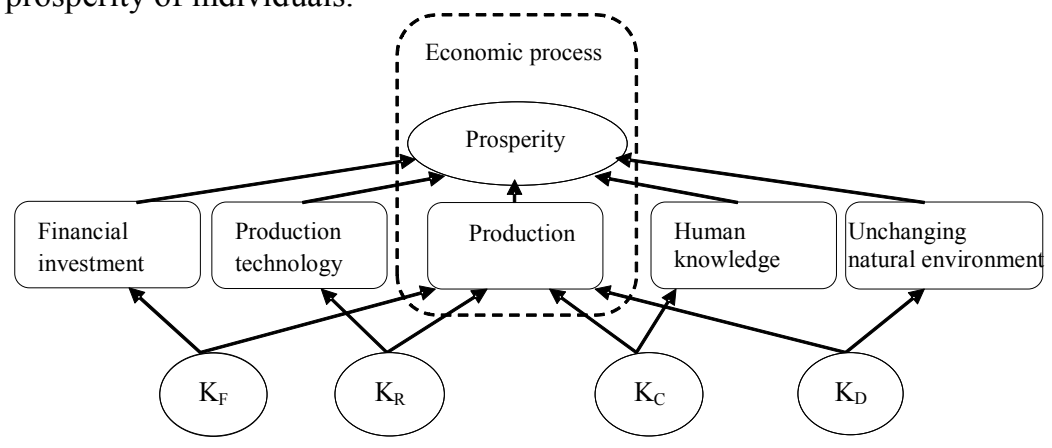

\section{Source: author's construction}

\section{Fig.1. Interaction of various types of capital in economic processes}

Figure 1 presents the interaction of various types of capital. The financial capital $\left(\mathrm{K}_{\mathrm{F}}\right)$, manufactured capital $\left(\mathrm{K}_{\mathrm{R}}\right)$ and human capital $\left(\mathrm{K}_{\mathrm{C}}\right)$ created and accumulated by humans as well as natural capital $\left(\mathrm{K}_{\mathrm{D}}\right)$ are used in economic processes to contribute to higher prosperity through producing goods and services. The exploitation of natural capital is an integral component of agricultural production. Natural capital is a source of inputs (UAA) for agricultural production and, undoubtedly, the most important factor of production. The outcome of economic activity directly depends on the way the UAA is exploited. Nevertheless, this production resource is also part of natural capital that has to produce ecosystem services. The impact of agricultural production on natural capital and the capability of the ecosystem to regenerate it have to be assessed. In this context, it is important to ensure optimum nutrient cycling in agricultural ecosystems, which can directly affect climate change. Agricultural production releases polluting emissions into the surrounding 
environment and reduces the value of natural capital, while also reducing the quality of life for humans; this hinders economic development, as any member of society does not benefit from this economic process. An evaluation of natural capital is done by identifying what economic value goods and services an ecosystem can produce using the available natural capital (Bartelmus P., 2008). Services produced by an ecosystem are identified based on the ecological and economic functions of natural capital; the services are classified into six categories (Common International Classification of Ecosystem Services - CICES) (European Environment..., 2011):

$>$ purification and filtration - air, water and soil are purified;

$>$ cycling - nutrient cycling, nitrogen fixation, carbon sequestration and soil formation;

$>$ regulation and stabilisation - pest and disease control, climate regulation, storms and floods, erosion control, precipitation and water supply;

$>$ biotypes - a shelter for animals and plants, a genetic material bank;

$>$ supply and production - biomass production for raw material and food, pollination and seed spread;

$>$ information and culture - aesthetic, recreational, cultural and mental importance, education and research.

Agricultural production is actually part of the entire ecosystem and can considerably affect the processes occurring in it. The total economic value (TEV) of an agricultural ecosystem is identified employing economic methods for evaluation of ecosystem services. Change in key indicators is essential in making decisions on the change of agricultural land use or in relation to activities that affect the condition of an agro-ecosystem and the services produced by it. The TEV of an agro-ecosystem service encompasses both a value related to the direct use of the service and a value arising from the indirect use of the service.

A direct use value arises from the interaction of humans with the ecosystem, which brings profits in the form of goods (biomass, mineral deposits, water) or in the form of services (recreation, education).

An indirect use value represents the ecosystem's capability of selfpreservation, nutrient cycling, climate stabilisation, carbon dioxide fixation and accumulation, as well as an attractive landscape and a human-untouched natural environment.

A non-use value relates to benefits from the existence, preservation and potential use of ecosystems that do not involve financial gains.

In evaluating a TEV of an agro-ecosystem service in agriculture, potential beneficiaries have to be divided into interest groups. The EU defines three levels of beneficiaries: local (parish/municipality), regional (Latvia) and world/global. In evaluating a TEV of an ecosystem of the agricultural sector, the key indicator is the UAA, namely, qualitative indicators of land use. In Latvia, organic soils (peat soil) are also used in agricultural production, which is a significant source of GHG emissions in the country. Tilling arable land 
with soils having a high content of organic matter (the organic layer is more than $10 \mathrm{~cm}$ in thickness) results in the release of stored carbon due to nitrification. This process contributes to climate change on a global scale.

The identification of a TEV of an ecosystem of the agricultural sector for organic soils allows assessing potential benefits from climate change reduction, as well as potential losses for farmers if they change their land use from arable land to grassland, which is impossible without financial assistance.

Agricultural GHG emissions could be reduced through a certain use of agricultural land.

\subsection{Agriculture in the context of economic development}

The efficiency of land resources, which constitute the main part of natural capital, has been different during various historical periods. In 2015, according to statistical data, the share of the agricultural sector in the gross domestic product (GDP) of developed EU Member States ranged from 1.1\% to 4\% (Agriculture in the..., 2016). The data are presented in Figure 2.

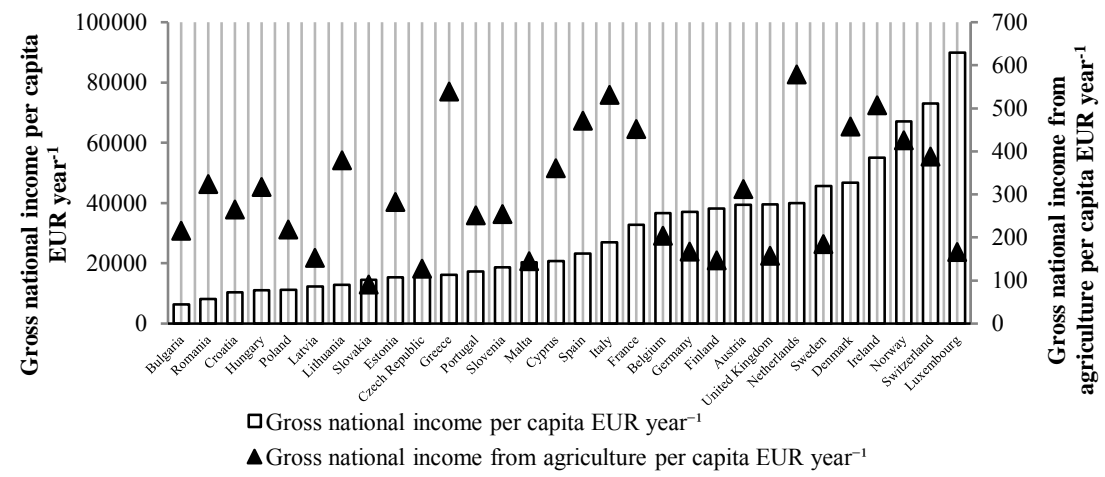

Source: author's construction based on Eurostat, 2015

Fig.2. Gross national income and national income from agriculture per capita in European countries in 2015, EUR year ${ }^{-1}$

Professor K. Špogis (2007) pointed out that "the role of agriculture and forestry in the national economy of Latvia is associated with the production of organic matter, energy accumulation and food production; it is a source of raw material for industrial processing, and rural and forest areas represent a residential and recreational space". The professor actually has implicitly pointed out that agriculture together with forestry are the basis of the bioeconomy of Latvia.

Fast changes in agriculture were due to economic globalisation. In the period 2005-2015 in the EU-28, the number of full-time employees in agriculture declined by $25 \%$. The largest decline in the number of full-time 
employees was reported in Bulgaria (60\%), Romania (50\%) and Latvia and Estonia (45\%) (Agricultural Labour..., 2015).

After aggregating information and constructing the agricultural development stages, the author of the dissertation concludes that agriculture developed mainly extensively during its classical period, i.e. the agricultural area increased. There were some attempts to use agricultural commodities for the production of non-food products. At the next stage, in the period 19601999, agricultural production and rural areas as a whole underwent significant economic changes. Seeking solutions to increasing agricultural output, the world's economically advanced countries, among them the EU, preferred production intensification. New ways of economic development for agriculture in the world's advanced countries and in the EU were sought after the year 2000. One can certainly expect further technological advancement because there are disparities in agricultural productivity among European countries after the EU enlargement of 2004. Even though Latvia demonstrated one of the fastest increases in agricultural productivity in the EU, the productivity in Latvia was still 16 times lower than in the Netherlands and 5 times lower than the EU average in 2015. The agricultural productivity of European countries in 2015 is shown in Figure 3.

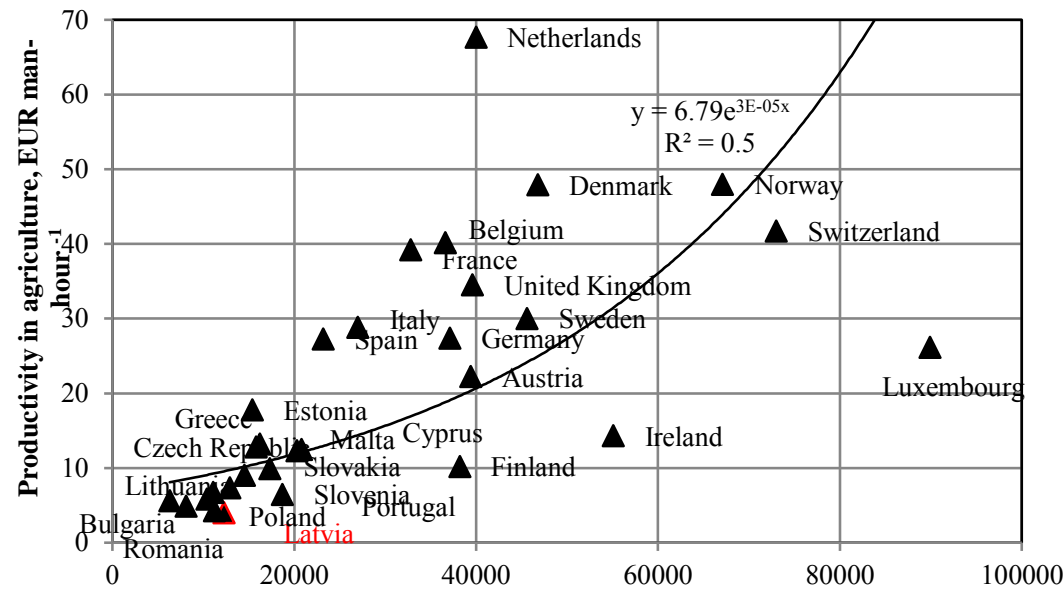

Gross national income per capita, EUR year ${ }^{-1}$

Sources: author's construction based on Eurostat, 2015

Fig.3. Correlation between agricultural productivity and gross national income per capita in European countries in 2015, EUR

A correlation analysis was performed to identify how strongly the economic development of the country, which is measured in gross national income per capita a year, relates to agricultural development, which is measured in the value of output per agricultural employee. There is a medium strong $\left(\mathrm{R}^{2}=0.5\right)$ 
correlation between agricultural productivity and gross national income per capita in European countries. In the opinion of the author, one can expect that with investment in agricultural modernisation remaining at the same level as in other advanced countries and the number of agricultural employees decreasing, productivity is going to rise. However, an increase in productivity is associated with an increase in the amount of resources used in production. For this reason, an increase in productivity in crop farming has to contribute to the sustainable use of the UAA, which means the use of the UAA has to be aimed at creating as small damage, in the form of polluting emissions, to the environment as possible.

An analysis of the agricultural development stages in Latvia and in the world reveals the role of agriculture in economic development, yet today the need for meeting and ensuring the principles of sustainable development increases. Sustainability as a concept and an adequate behaviour of any individual are strongly associated with economic development (Sarma V., 2012).

Sustainable development is a kind of development that allows meeting today's needs without compromising the ability of future generations to meet their own needs. Sustainability is a concept existing since 1955, and the Russell Einstein manifest (The Russell Einstein..., 1955) deliberately discussed for the first time the need for such an attitude that is able to ensure political responsibility for future generations.

Sustainable development has three dimensions: economic, social and environmental.

A definition and an explanation of the term sustainable development is available in the World Charter for Nature adopted by the UN General Assembly in 1982 (World Charter for...,1982). The historical beginning of the concept of sustainable development is considered to be a 1987 report Our Common Future by the UN World Commission on Environment and Development or the Brundtland Commission, also known as the Brundtland Report (The World Commision..., 1987).

A turning point in the formation of the concept of sustainable development was a World Earth Summit held in Rio de Janeiro in June 1992 (World Earth..., 1992). At the end of 1997, the Kyoto Protocol, ratified by the Saeima of the Republic of Latvia in 2002, was adopted to introduce the United Nations Framework Convention on Climate Change.

To progress towards sustainable agriculture, the EU adopted the Nitrates Directive in 1991, which is one of the EU legal acts on pollution control and water quality enhancement as well as sustainable use of natural resources (Direktīva..., 1991). The next important step towards sustainable development in Europe is the EU strategy "Europe 2020: a Strategy for Smart, Sustainable and Inclusive Growth" (Eiropa 2020).

Sustainable economic development occurs if prudently managing all available resources and caring about biodiversity on the Earth. Sustainable 
development contributes to overall prosperity and gives any individual an opportunity to live is a healthy environment, fulfilling his/her own wishes and needs. Article 2 of the Convention on Biodiversity gives an explanation of the term sustainable use, stating that it means "the use of components of biological diversity in a way and at a rate that does not lead to the long-term decline of biological diversity, thereby maintaining its potential to meet the needs and aspirations of present and future generations".

After 2020, alternative uses emerge for land as a production resource. Agricultural land began to be used for the production of non-food products. It is much discussed whether the world is capable of providing food to the growing population on the planet if land is used for the production of non-food products (WWF, 2010).

The geographical location of Latvia and the resources available, in the author's opinion, are considered to be comparative advantages to effectively compete with other countries under globalisation. After analysing the key agricultural economic development indicators in European countries, one can find that output growth in Latvia is potentially possible. An essential role in designing a future development strategy is played by the bioeconomy. The purpose of it is to create an innovative economy with low $\mathrm{CO}_{2}$ emissions and maintain a balance among such factors as sustainable agriculture, forestry, fisheries, food security and the use of renewable bioresources in industry, while contributing to biodiversity and preserving the environment.

Bioeconomics is a progressive interdisciplinary science that seeks to integrate economics and biology with the only purpose - to create a better theory that explains economic processes based on scientific biotechnology principles. Bioeconomics involves the change of paradigms for economic development and integrates into a single system natural resource economics, environmental economics and ecological economics (Akerlof G., 1970).

Bioeconomics seeks to integrate the biomass flow from various industries in a way that the waste or by-products of one industry is an input for another industry. This approach is a means for establishing effective material flow cascades, while avoiding climate change and resource depletion problems (OECD, 2010; EuropaBio, 2010).

The development of bioeconomics is based on scientific research into biotechnologies. The change of a paradigm in economic thinking is necessary rather than just simple replacement of fossil resources with renewable sources (KBBE, 2010).

The development of bioeconomics and biotechnologies will ensure the creation of knowledge-based bio-products, overall growth and a growing demand. Such an approach to the processing of bioresources produced by the agricultural industry will lead to technological change and increasing returns from resources (Reinert E., 2007). 


\subsection{Sustainable and intensified agriculture}

Examining the historical agricultural development stages, a causal association could be clearly seen between the development of the rural environment and change in economic thinking. Agriculture with its specific kind of production is a unique component of the entire economic, environmental and social system. The key objective and task of agriculture is to produce food for the population. Analysing the achievement of the objective in global context, the author of the dissertation has to admit that the situation in various world regions is diverse. According to estimates made by scientists, the supply of food to seven billion people requires exploiting a third of dry land agro-ecosystems and approximately a half of fresh water reserves, as well as doubling the available amount of nitrogen and phosphorous in the environment (Vitousek P.M., 1997). Contributing to global economic growth, agriculture has ended up at the beginning of a complicated development cycle, as the increasing demand for agricultural products has to be met by following the principles of sustainability, beginning with the production of agricultural products through to processing and supply to final consumers (Charles H., 2010).

The author of the dissertation sets four key criteria for the indicators of sustainability and intensified agriculture: 1) the indicator identifies, evaluates and characterises the condition of the system;2) the indicator allows projecting the development of the system and achieving the objective; 3) the indicator gives information on the efficiency of an activity done; 4) the indicator provides information for the social groups involved in the system.

Extensive agriculture on a global scale is simply not possible anymore, as there is no available appropriate land for agriculture, and the growing demand for food has to be met by agricultural intensification, which, in its turn, results in growing impacts on climate change. This is in contradiction to the principles of sustainability. The definition of agricultural development encompasses two inseparable keywords - "sustainable" and "intensified" development -, and the measurement of it involves four key pathways: 1) increasing the efficiency of every land parcel; 2) maintaining and raising the value of every land parcel; 3) reducing the amount of resources used in production; 4) raising the value of services produced by ecosystems.

The author suggests the following definition of sustainable agricultural intensification: sustainable intensification is an agricultural production system in which an increase in output is achieved in the existing utilised agricultural area without reducing the existing value of agro-ecosystem natural capital.

The system, the introduction of which was recognised by the Republic of Latvia by ratifying the Kyoto Protocol, envisages that the global climate change reduction target has to be transferred to and imposed at lower levels, distributing it among the non-ETS sectors. GHG emission indicators have to be assigned to every sector. Agricultural enterprises have to be ready to be able to 
assess their effects on the natural environment, as research is done at EU level on the system of GHG emission quota trading or GHG certificate introduction in the non-ETS sectors (Lenerts A., 2015). However, in the author's opinion, research studies focusing on a detailed examination of interaction of all the sustainability categories to find solutions to the land resource use that balances the production of socio-economic and ecosystem services have to be rated higher (Pretty J., 2011; Foley J., 2011; Geraldo M.B., 2012).

The examination done by the author allows concluding that disagreement on assessment of sustainable intensification has not been solved (Pretty J., 2014). A comparison of methods for assessment of sustainability is presented in Table 1.

Table 1

Evaluation differences between weak and strong sustainability

\begin{tabular}{|l|l|l|}
\hline Goal of sustainability & \multicolumn{1}{|c|}{ Weak sustainability } & \multicolumn{1}{c|}{ Strong sustainability } \\
\hline Economic growth & $\begin{array}{l}\text { Increase in quantitative } \\
\text { indicator values }\end{array}$ & $\begin{array}{l}\text { Limited increase in } \\
\text { quantitative indicator values }\end{array}$ \\
\hline Maintenance of capital & $\begin{array}{l}\text { The sum of values of all types } \\
\text { of capital is constant }\end{array}$ & $\begin{array}{l}\text { The sum of values of natural } \\
\text { and the other types of capital } \\
\text { is constant }\end{array}$ \\
\hline $\begin{array}{l}\text { Natural capital } \\
\text { preservation }\end{array}$ & $\begin{array}{l}\text { It could be replaced with } \\
\text { another type of capital }\end{array}$ & $\begin{array}{l}\text { It could not be replaced with } \\
\text { another type of capital, as it } \\
\text { is limited }\end{array}$ \\
\hline $\begin{array}{l}\text { Achievement of } \\
\text { sustainability }\end{array}$ & $\begin{array}{l}\text { Increase in the efficiency of the } \\
\text { factors of production } \\
\text { (technology, growth, market) }\end{array}$ & $\begin{array}{l}\text { Growth limitation; } \\
\text { government policies aimed at } \\
\text { achieving higher efficiency }\end{array}$ \\
\hline Future development & $\begin{array}{l}\text { Economic system (efficient use } \\
\text { of natural capital) }\end{array}$ & $\begin{array}{l}\text { Environmental agro- } \\
\text { ecosystem (increase in the } \\
\text { value of natural capital) }\end{array}$ \\
\hline $\begin{array}{l}\text { Assessment of the } \\
\text { condition of the } \\
\text { environment }\end{array}$ & $\begin{array}{l}\text { A source of the factors of } \\
\text { production to provide } \\
\text { prosperity }\end{array}$ & $\begin{array}{l}\text { The basis for human survival } \\
\text { and existence }\end{array}$ \\
\hline
\end{tabular}

Source: author's construction based on Kaphengst T., 2014

In agricultural production, the concept of sustainability has three interrelated dimensions: rural environment preservation, economically feasible performance of agricultural holdings and employment in rural areas.

Setting a goal to create an economic development model for sustainable agricultural production requires analysing changes in the values of the most relevant indicators of the sustainability dimension. The indicators are used to identify what externalities are created by the change of the economic model.

Making policies on the use, management, saving and preservation of resources, the potential behaviour of individuals of a society have to be taken into consideration to achieve the targets set in sustainable development strategies in relation to the reduction of GHG emissions from agriculture in European countries (Decision..., 2009). Based on a methodology developed by 
J. Cramer (Cramer J., 2007), the author selected the most relevant indicators for each sustainability dimension and assessed the development of agricultural production in Latvia. The environmental dimension of sustainable development shows an increase in the amount of resources used in production, which, in its turn, produces more environmental pollution. In agriculture, they are fossil fertilisers and related $\mathrm{CO}_{2}$ emissions. The economic dimension of sustainability captures changes in the quantities of crop and livestock products. The social dimension of sustainability assesses employment in agriculture.

The agricultural development indexes calculated are presented in Figure 4.

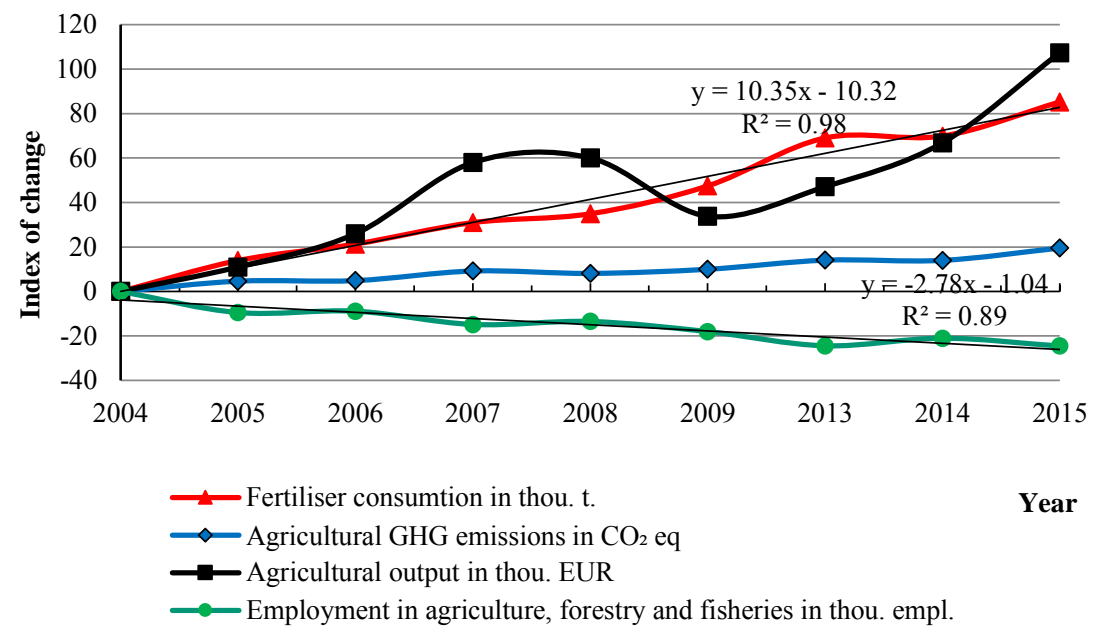

Source: author's construction based on the CSB, 2016

\section{Fig.4. Agricultural development indexes $(2004=100)$ in Latvia in the period} $2004-2015$

The indicators of agricultural development in Latvia show that it is problematic to achieve the economic development targets. The amount of mineral fertilizers used during the study period increased by 10 thou. t. but the number of employed is decreasing by 2.7 thou. people every year. Even though the output of agricultural products grew after joining the EU in 2004, environmental impacts have also increased (GHG emissions from agricultural activity). Intensification in crop farming requires more fossil resources (fertilisers). Employment has considerably decreased, thereby creating social risks in rural areas. Agricultural growth has caused externalities that make meeting the principles of sustainability problematic in a long-term. Agricultural growth may not be considered economic development if it has not contributed to the prosperity of any member of society in Latvia.

In the author's opinion, the capability of the agricultural sector to adapt to the new climate change policy, which transformed from recommendatory to 
being binding, could significantly affect agricultural development in Latvia. The largest effect relates to emission reduction measures.

\section{DEVELOPMENT OF AND THE LEGAL AND INSTITUTIONAL FRAMEWORKS FOR AGRICULTURAL AND ENVIRONMENTAL POLICIES}

The chapter is 17 pages long and includes 1 table and 9 figures.

The chapter provides a detailed analysis of a synergy of agricultural and environmental policies. It also analyses the legal framework regulating agriculture and the natural environment and the chapter characterises the institutional system for assessment of environmental impacts of agriculture.

The chapter puts forward a thesis: sustainable agricultural development is ensured by a synergy between agricultural and environmental policies, the achievement of which is based on the legal acts passed and the institutional system created.

A new market economy model was introduced in practice in agriculture in the post-war Europe (Eise S., 2012). The single market economy model unified two seemingly contradictory factors: a free and a government-regulated market, thus creating a social market economy (Joerges C., 2004). Such an economic model could function based on specific government policies. At present, the EU has assumed the leading role in making sustainable agricultural policies. The EU Sustainable Development Strategy was designed and adopted in Goteborg in 2001; it was enhanced in 2006. In 2006, the European Commission came up with an important document in the field of energy - the Green Book (European Commission, 2006).

In 2016, agricultural matters were integrated into the common EU development strategy Europe 2020; for this reason, achieving the targets set by the initiatives - the Innovation Union and the Resource-Efficient Europe - is binding upon the agricultural sector. The climate change mitigation and energy target $(20 / 20 / 20)$ is aimed at reducing GHG emissions by $20 \%$ in 2020 compared with 1990, 20\% energy produced from renewable sources as well as $20 \%$ higher energy efficiency, which directly relates to agriculture as well (Direktivva, 2009). Every Member State's targets and progress measurement indicators are set based on the common EU targets (Decision, 2009).

The achievement of the targets set by the EU initiative Resource-Efficient Europe is based on the change of the climate and energy policy. The policy is based on four pillars, and each of them has an adequate legal framework:

strengthening and extending the EU Emission Trading System (ETS), which is the key tool for reducing the emissions in an economically efficient way. It is projected that emissions from the ETS sectors will be reduced by $21 \%$ by 2020 compared with the 2005 level. A single 
framework will be created for the ETS in the EU, and granting emission quotas for free until 2020 will be replaced with quota auctions;

$>$ emissions from the sectors that are not included in the EU ETS - transport, households, agriculture and waste management (non-ETS sectors) - are projected to be reduced by $10 \%$ by 2020 compared with the 2005 level. Based on its relative prosperity level, every Member State has to set a national emission reduction target in the range from $-20 \%$ for the richest Member States to $+20 \%$ for the poorest Member States in order to achieve the planned emission reduction in the entire EU;

$>$ binding targets for the share of renewable energy sources (RES) in gross final energy consumption. The average share for the EU is set at $20 \%$ by 2020 (more than a two-fold increase compared with 2006 when the share of RES was 9.2\%). The binding targets for every Member State are different and vary from $10 \%$ for Malta to $49 \%$ for Sweden;

$>$ it is planned to establish a network of carbon capture and storage stations until 2020.

Achieving the GHG emission reduction targets is problematic for Ireland, Austria, Finland, Belgium and Spain, while Latvia is in the group of Member States that has to design additional measures to achieve the emission reduction target.

\subsection{Synergy of agricultural and environmental policies}

The use of natural capital for agricultural production after the social market economy model has been introduced is regulated by means of the CAP. The use of natural capital for agricultural development is well reflected in the CAP's historical stages.

Achieving the CAP targets with regard to competitive, sustainable and environment-friendly development in agriculture, progress occurred towards liberalising the market of agricultural goods through reducing the regulatory role of government in it. Sustainable and environment-friendly development was achieved by introducing considerable financial support for biofuel production from agricultural commodities $\left(\mathrm{CO}_{2}\right.$ loans, support for energy crops).

\section{CAP reform in 2013}

The reform that was implemented in 2013 was the newest CAP adaptation process stage, and it is still not over. It introduced a new architecture of direct payments and better targeted, more equitable and greener, an enhanced safety net and strengthened rural development (European Commission, 2013). The EU CAP framework for the period 2014-2020 focuses on the factors faced by agriculture and rural areas on the way towards economic development and growth

A synergy of the CAP and environmental policies in relation to their historical stages is presented in Figure 5. 


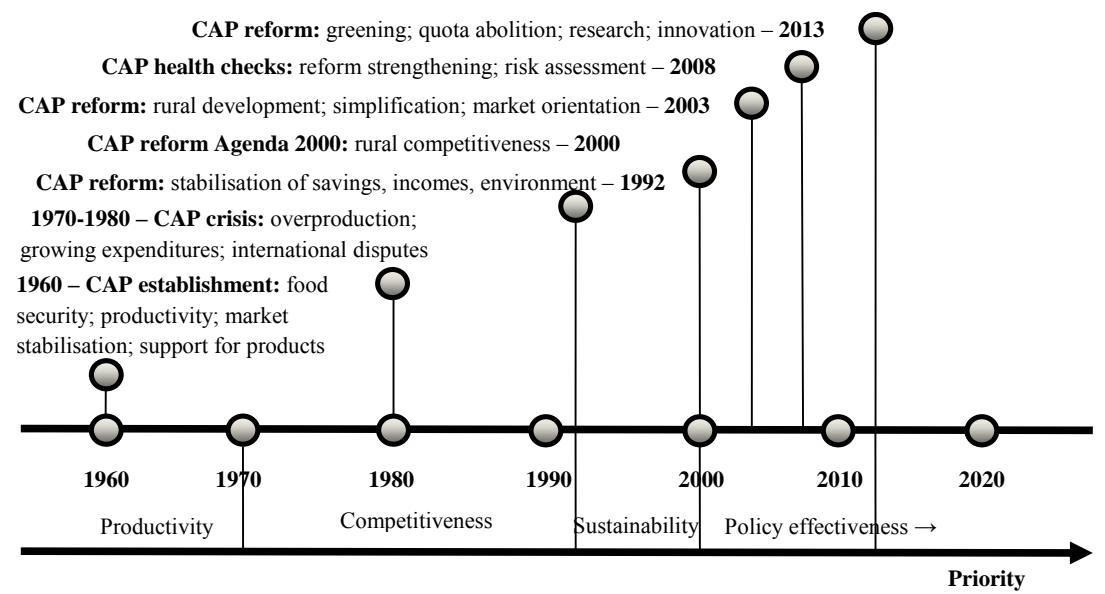

Source: author's construction

Fig.5. Synergy of EU agricultural and environmental policies for the period up to 2020

After Latvia joined the EU, one of the tasks to be performed was the startup of biofuel (bioethanol and biodiesel fuel) production. Later on, biogas production from agricultural raw material emerged and developed very fast.

In the period 2014-2020, there were set compliance prerequisites for the EU CAP in relation to payments for climate- and environment-friendly agricultural practices or the "green component" - the compulsory direct payment component, which has to account for $30 \%$ of the total amount of direct payments and which is granted as an extra payment to all recipients under the Single Area Payment Scheme if they respect the practices aimed at climate change reduction, biodiversity preservation, environmental protection, $\mathrm{CO}_{2}$ emission reduction and fixation. There are three major pathways: crop diversity - a certain number of crop species has to be grown in a certain land area; preservation of permanent grasses - a certain area under grasses has to be part of the total area declared for direct payments; establishment of ecological focus areas - a certain area of arable land has to be managed in accordance with the basic principles set for ecological focus areas (European Commission, 2013; Frelih-Larsen A., 2014).

\subsection{Legal documents regulating agriculture in Latvia}

An appropriate legal framework adopted in every Member State, which is also harmonised with relevant international and EU legal documents, is the most important aspect in achieving the EU CAP targets.

Agriculture, given its specifics with regard to production conditions, is the most regulated field of business. In the context of use of natural capital, 
agriculture is regulated by legal documents passed in various periods: conventions, international treaties, EU directives and regulations, laws of the Republic of Latvia, Cabinet regulations, policy documents and programmes. To structure the legal acts regulating and influencing agriculture, the author suggests dividing them into three groups. The first group is comprised of general laws binding on business that apply to accounting and taxes, legal transactions and commercial activity. The second group consists of international conventions, EU regulations and national laws applying to agriculture. The third group includes international conventions, EU regulations and national laws that regulate the use and protection of the environment (natural capital).

An analysis of the legal acts regulating agriculture in Latvia was based on the Rural Development Programme 2014-2020 (RDP). It is the most important document in the hierarchy of regulatory legal acts that encompasses EU and international legal documents and shapes rural and agricultural development in Latvia.

The UN Framework Convention on Climate Change significantly influences agriculture in Latvia.

The stages of decision-making and legal act adoption, which are harmonised with the recommendations and relate to agricultural GHG emission reduction, are presented in Figure 6.

Setting GHG reduction targets binding on Latvia - 2016

30 June 2015. An assessment of GHG reduction target achievement -2015

15 March 2015. Effort Sharing Decision (ESD) - 2015

15 January 2015. The 2013 national GHG inventory report is submitted - 2015

Initial assessment of the GHG inventory -2014

ESD No. 406/2009/EC. GHG reduction target adoption - 2009

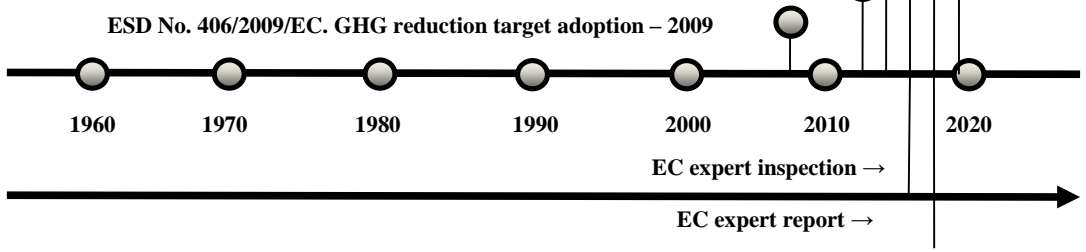

Source: author's construction

Fig.6. Key stages of the adoption of agricultural GHG emission reduction targets

The Convention adopted in 1992 and the Kyoto Protocol, ratified by the Saeima of the Republic of Latvia, impose an obligation on Latvia to reduce GHG emissions causing global warming. In accordance with the Kyoto Protocol, Latvia has set GHG emission reduction targets for 2020, considering the 1990 emission level. An active process of setting GHG reduction targets for agriculture takes place in Latvia. Coupling the GHG reduction targets with 
agricultural development, in the opinion of the author, is going to determine it in the future.

The targets and priorities set by the EU CAP reform, which were unified for all the EU Member States for the programming period 2014-2020, were taken into consideration in developing the national RDP 2014-2020, thereby highlighting a new approach that differed from earlier practices when the RDP priorities were set individually within the context of every Member State. In developing the national RDP 2014-2020, its association with the national and EU environmental policy documents was taken into account as well.

\subsection{Institutional system for assessing agricultural impacts on the environment}

In order that Latvia can effectively meet its international commitments in the field of climate change, a reduction of additional GHG emissions requires meeting a number of other requirements: to establish a national system for calculating $\mathrm{GHG}$ emissions and $\mathrm{CO}_{2}$ fixation and producing annual reports; to support scientific research on climate change; as well as to inform the public on matters related to the climate change. The Ministry of Environmental Protection and Regional Development (MEPRD) of the Republic of Latvia coordinates the achievement of the GHG reduction target for the non-ETS sectors, including agriculture. The Ministry of Agriculture (MA), the Ministry of Transport (MT) and the Ministry of Finance (MF) develop and implement climate change mitigation policies. The MEPRD is the leading state administrative institution in the field of environmental protection, which also involves preventing climate change and adapting to it. Cabinet Regulation of 30 November 2004 No. 962 (Vides dienesta, 2004) regulates the functioning of the State Environmental Service and prescribes assessments of environmental impacts of agriculture, performing the tasks set in the law "On Pollution" in relation to granting (GHG emission) permits to carry out a polluting economic activity. The Service controls compliance with the requirements set in the laws on the extraction and exploitation of natural resources, environmental protection, the emission of polluting substances into the environment, hazardous and household waste management, packaging recycling and activities with chemicals and chemical products.

\section{The national system for calculating GHG emissions and $\mathrm{CO}_{2}$ fixation}

In accordance with the Framework Convention and the Kyoto Protocol, any party of the Convention has to annually submit a national inventory report on anthropogenic GHG emissions and their fixation to the UN Convention Secretariat.

An annual inventory of GHG emissions and their fixation and an annual inventory report are prepared by the Latvian Environment, Geology and Meteorology Centre, which is a governmental service subordinate to the MEPRD. In accordance with Cabinet Regulation of 27 March 2012 No. 217, 
the Centre performs GHG emission calculations. An inventory is prepared in cooperation with the CSB, the ME, the MT and the MA as well as the subordinate institutions. Experts from LLU are involved in calculating agricultural GHG emissions. An assessment of the accuracy of an inventory report is done by foreign experts from private organisations, enterprises and relevant scientific disciplines.

The data included in a report of GHG emissions reflect the achieved results with a two-year lag. Therefore, the part of the climate policy and measures that focuses on assessing the future impacts of GHG reduction measures and increasing the potential $\mathrm{CO}_{2}$ fixation is important and integral. Kyoto Protocol progress reports, national reports under the Framework Convention as well as reports on compliance with the EU legal documents are based on high-quality forecast data and assessments of the impacts caused by the planned and implemented measures. LLU plays an important role in producing GHG emission and $\mathrm{CO}_{2}$ fixation forecasts.

The national legal acts regulating agriculture and natural environment protection and the institutional environment comply with the requirements set by the international agreements. In the future, LLU scientists have to be involved in assessing GHG reduction measures to a greater extent, given the fast growth of the agricultural sector in Latvia.

\section{INDICATORS OF AGRICULTURAL PRODUCTION AND ITS IMPACTS ON THE NATURAL ENVIRONMENT IN LATVIA}

The chapter is 24 pages long and includes 14 tables and 8 figures.

The chapter analyses changes in the use of agricultural land, the development of agricultural holdings and GHG emissions. It is projected that GHG emissions from agriculture are going to increase.

The chapter puts forward a thesis: Latvian agriculture, crop farming in particular, develops dynamically and contributes to the production of GHG emissions.

The natural capital of Latvia is its land. According to a definition suggested by A. Dobele (2005), "land is an area characterised by certain nature properties - terrain, climatic conditions, soil, and aboveground and underground resources as well as a particular geographical location and a particular use".

The term land encompasses its diverse functions, and the use of land has to be viewed from the environmental, economic and social perspectives. The author assessed the efficiency of use of land as a resource in agriculture by employing the economic and environmental indicators of agriculture. The author has concluded that the efficiency of use of agricultural land in Latvia in the future will depend on whether the land is exploited in a sustainable and 
functionally appropriate way. From this perspective, the efficiency of use of agricultural land resources has been little researched in Latvia. The research studies do not focus on how to achieve the target from the economic perspective by exploiting all the available agricultural land resources, while also ensuring the functional use of land in relation to environmental problems, pollution reduction in the form of GHG emissions.

\subsection{Characteristics of land use in agriculture}

Land use has to be rational, efficient and sustainable. If it is not possible to use land for agriculture, it has to be used for forestry, construction or other purposes in order to contribute to the economy, benefiting residents economically, environmentally and socially.

In 2015 , agriculture and forestry exploited $88 \%$ of the total land resources of Latvia, and the UAA comprised $36.4 \%$ and the forestland area $-51.8 \%$ of the total area of the country. As of 1 January 2016, according to State Land Service (SLS) data on all real property uses, the total agricultural area (AA) was equal to 2350.8 thou. ha and the total forestland area was 3347.1 thou. ha.

A data analysis shows that the forestland area tended to increase. In the period of analysis, the agricultural area continued decreasing and, according to the statistical data for 2015, only 1884.8 thou. ha were used for agricultural production. Almost $20 \%$ of the available land resources are not used for agriculture, as the land is overgrown or unfarmed.

Changes in the quantitative indicators of agricultural land resources in Latvia for the period 1990-2015 broken down by land use are shown in Table 2.

Table 2

Types of agricultural land uses in Latvia in the period 1990-2015, thou. ha

\begin{tabular}{|r|c|c|c|c|c|c|c|c|c|c|c|}
\hline \multirow{2}{*}{ Year } & \multirow{2}{*}{$\begin{array}{c}\text { AA } \\
\text { thou. }\end{array}$} & \multicolumn{3}{|c|}{ UAA } & \multicolumn{2}{|c|}{$\begin{array}{c}\text { Arable } \\
\text { land }\end{array}$} & \multicolumn{2}{c|}{$\begin{array}{c}\text { Permane } \\
\text { nt crops }\end{array}$} & \multicolumn{2}{|c|}{$\begin{array}{c}\text { Meadows, } \\
\text { pastures }\end{array}$} & \multicolumn{2}{|c|}{$\begin{array}{c}\text { Unfarmed } \\
\text { area }\end{array}$} \\
\cline { 3 - 13 } & thou. & $\%$ & $\begin{array}{c}\text { thou. } \\
\text { ha }\end{array}$ & $\%$ & $\begin{array}{c}\text { thou. } \\
\text { ha }\end{array}$ & $\%$ & $\begin{array}{c}\text { thou. } \\
\text { ha }\end{array}$ & $\%$ & $\begin{array}{c}\text { thou. } \\
\text { ha }\end{array}$ & $\%$ \\
\hline 1990 & 2567.0 & 2534.0 & 98.7 & 1656.0 & 65.4 & 35.9 & 1.4 & 847.7 & 33.5 & 33 & 1.3 \\
\hline 1995 & 2501.3 & 1832.1 & 73.2 & 1002.3 & 54.7 & 19.3 & 1.1 & 800.5 & 43.6 & 669.2 & 26.8 \\
\hline 2000 & 2484.9 & 1587.2 & 63.9 & 969.9 & 61.1 & 11.5 & 0.5 & 605.7 & 38.2 & 897.7 & 36.1 \\
\hline 2005 & 2474.4 & 1733.7 & 70.0 & 1091.8 & 62.9 & 12.8 & 0.7 & 628.9 & 36.2 & 740.7 & 30.0 \\
\hline 2010 & 2430.0 & 1815.5 & 74.7 & 1173.4 & 64.6 & 6.8 & 0.4 & 625.2 & 34.4 & 614.5 & 25.3 \\
\hline 2015 & 2350.8 & 1884.8 & 80.2 & 1229.8 & 65.2 & 6.7 & 0.3 & 648.3 & 34.4 & 466.0 & 19.8 \\
\hline $\begin{array}{c}\text { Change } \\
\text { from base } \\
\text { year, \% }\end{array}$ & -8.4 & -25.6 & -18.5 & -25.7 & -0.2 & -81.3 & $\mathrm{x}$ & -23.5 & +0.9 & +1312 & +18.5 \\
\hline
\end{tabular}

Source: author's construction based on the CSB, 2015

To some extent, such a situation does not contribute to competition, as it could be an effective solution to the problem of inefficient use of land in Latvia. Land policy scenarios envisage that the demand for agricultural land is going to rise over the next decades because of the growing demand for food (Zemes politikas..., 2008). 
The author used data for a period since 1990 for an assessment of land use efficiency and a comparison of agricultural output and inputs. This is the reference year for GHG emission inventory calculations. Land use efficiency from the environmental perspective was identified by calculating the amount of emissions produced per unit of inputs.

The enhancement of quantitative indicators of the UAA was due to the following objective factors:

$>$ Cabinet Regulation No. 635 "Procedures for Surveying and Identifying the Unfarmed Utilised Agricultural Area and Providing Information thereon" has been in force since 13 July 2010 (Kārtība, kādā..., 2010);

$>$ amendments were made to Cabinet Regulation No. 126 "Procedures for Granting Direct Payments to Farmers", changing the procedure of granting support payments to agricultural land owners from the European Agricultural Guarantee Fund, which have been in force since 10 March 2015. Restrictions were imposed on receiving payments under the Single Area Payment Scheme (SAPS) for agricultural land if the terms related to land use for production were not met (Tiešo maksājumu..., 2015).

Increase in the UAA may not be an indicator of efficiency of its use. Qualitative indicators are more important in assessing the efficiency of land use. Increase in the UAA represents the extensive development path, and such development means growth due to increases in the factors of production. A research project on efficient UAA use under the guidance of professor I. Pilvere carried out at Latvia University of Agriculture (LLU) found that an area of 1459 thou. ha was exploited for agricultural production (Pilvere I. et al., 2014). In 2015 in Latvia, an area of 1660 thou. ha was declared for SAPS. Agricultural development in various areas of Latvia is different, and the areas could be classified as follows: 1) intensive agricultural areas that include the central part of the country and some municipalities in the areas being remote from the capital city (900 thou. ha); 2) extensive agricultural areas with subsistence farming, where agricultural produce is not sold in the market but used for self-consumption (535 thou. ha) (Saktina D., 2006).

An analysis of the quantitative data on agriculture has identified the key agricultural production sectors that make up a considerable share of the total value of output. The sectors are the key users of the factors of production and contributors to environmental impacts. In 2015 in Latvia, total agricultural production in constant prices consisted of: grain $33.1 \%$, milk $17.7 \%$, feed crops $/$ maize $10 \%$, rapeseed $8 \%$, pork $5.1 \%$, vegetables $4.9 \%$, potato $4.3 \%$, beef $3.5 \%$, poultry $3.5 \%$, eggs $3.4 \%$, other livestock products $3.2 \%$ and other crop products $3.2 \%$ (Latvijas lauksaimniecība, 2016).

In Latvia, agriculture develops, exploiting land resources, both through intensification and extensive expansion. Grain production is the key agricultural industry that supplies food to the population and feed to dairy and meat livestock farms. Grain, milk, rapeseed and feed crop/maize production accounted for $70 \%$ of the total value of final agricultural products in Latvia in 
2015. To identify the efficiency of use of land resources, the author analyses the use of agricultural land resources in relation to environmental indicators expressed as $\mathrm{GHG}$ emission $\mathrm{CO}_{2}$ equivalent in Subchapter 3.2.

\subsection{Characteristics of agricultural holdings}

In the period 2005-2015, economic processes considerably affected the performance of Latvian agriculture, especially crop farming. In the author's opinion, particularly changes in the economic processes in agriculture determine the trajectory of its development in the future.

In Latvia, the use of land resources by agricultural holdings is affected by diverse environmental factors in the regions. Some regional specialisation exists because of the mentioned diverse factors. The use of land resources has to be assessed in terms of the potentially best functional land use (Schulte R., 2014).

The author fully agrees with this opinion, yet alongside economic categories, also environmental and social categories have to be employed to promote economic processes in order that agricultural development is sustainable. The author used the distribution of farms by economic size, which is characterised by the standard output (SO) of products and the farm type, for an economic analysis of economic processes in Latvia. The standard output of an agricultural product is the monetary value of the agricultural output at farmgate price in the region, in euro per hectare or per head of livestock. The total $\mathrm{SO}$ of an agricultural holding represents the economic size of the holding in terms of money. The CSB uses standard outputs per hectare of crops or per head of livestock calculated by the Latvian State Institute of Agrarian Economics (since 2016 - the Institute of Agricultural Resources and Economics) to identify the economic size of holdings (CSB, 2016).

Such a distribution was chosen to identify the groups of farms that affect economic processes as well as agricultural sustainable development the most. According to farm survey data, there were 81796 agricultural holdings in Latvia at the end of 2013 (CSB, 2016). An analysis of the indicators of agricultural holdings reveals that field crop farms affected agricultural sustainable development in Latvia the most, as the SO of the farms accounted for $37 \%$ of the total output of agricultural products. The other most significant types of farms were as follows: dairy with $28 \%$, mixed crops and livestock with $14 \%$, pigs and poultry with $13 \%$ of the total SO.

The total number of agricultural holdings decreased in Latvia by $39 \%$ in 2013 compared with 2005 . The structural changes of agricultural holdings have considerably affected holdings of small economic size, the number of which decreased sharply - by $44 \%$.

The calculation results for the structural changes of agricultural holdings is presented in Table 3. 
Table 3

Changes in farm structure by economic size group in Latvia in the period 2005-2013, thou. EUR

\begin{tabular}{|c|c|c|c|c|c|c|c|c|}
\hline \multirow{2}{*}{ 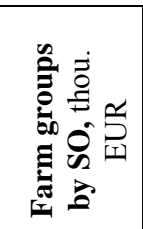 } & \multicolumn{2}{|c|}{2005} & \multicolumn{2}{|c|}{2010} & \multicolumn{2}{|c|}{2013} & \multicolumn{2}{|c|}{$\begin{array}{c}\Delta \text { from base } \\
\text { year, \% }\end{array}$} \\
\hline & $\begin{array}{c}\text { Numb } \\
\text { er }\end{array}$ & $\begin{array}{c}\text { UAA, } \\
\text { thou. } \\
\text { ha }\end{array}$ & $\begin{array}{c}\text { Numb } \\
\text { er }\end{array}$ & $\begin{array}{c}\text { UAA, } \\
\text { thou. } \\
\text { ha }\end{array}$ & $\begin{array}{c}\text { Numb } \\
\text { er }\end{array}$ & $\begin{array}{c}\text { UAA, } \\
\text { thou. } \\
\text { ha }\end{array}$ & $\begin{array}{c}\text { Numb } \\
\text { er }\end{array}$ & $\begin{array}{c}\text { UA } \\
\mathrm{A}\end{array}$ \\
\hline $\begin{array}{c}\text { Less than } \\
14.9\end{array}$ & 131237 & 1204.7 & 76277 & 774.9 & 73603 & 683 & -44 & -43 \\
\hline $15.0-99.9$ & 1521 & 209.0 & 6002 & 441.5 & 6754 & 471.4 & 344 & 63 \\
\hline $\begin{array}{c}\text { more } \\
\text { than } 100\end{array}$ & 247 & 2 & 1107 & 580 & 1439 & 723.3 & 483 & 129 \\
\hline Total & 133005 & 1705.2 & 83386 & 1796.3 & 81796 & 1877.7 & -39 & 10 \\
\hline
\end{tabular}

Source: author's construction based on the CSB, 2016

The number of the farms with a SO of more than EUR 100 thou. increased, and there were 1439 such farms at the end of 2013 or 5.8 times more than in 2005. After 2005 in Latvia, the same economic processes occur as in the EU and the world. Small agricultural holdings are endangered the most, as the economic pattern - farming as business - dominates.

\subsection{Agricultural production and GHG emissions from it}

In order to control and correct the GHG emission reduction targets set in the $\mathrm{EU}$, an appropriate system for calculating and accumulating indicative indicators is necessary, which is done in Latvia in accordance with Cabinet Regulation of 27 March 2012 No. 217 (Noteikumi par siltumnīcefekta..., 2012). The climate change mitigation targets set by EU Member States (Decision No 406/2009) aim to reduce GHG emissions by 20\% in 2020 compared with 1990.

Agriculture is among the sources of emissions that are not included in the quota trading system (non-ETS). However, to achieve the targets of the strategy Europe 2020 in relation to the reduction of GHG emissions from transport, households, agriculture and waste management, every country has to produce and submit national inventory reports to the UN. A document provides the following information: 1) a national GHG emission inventory (NIR) (Latvia's National..., 2015); 2) numerical data on national GHG emissions arranged according to the Common Reporting Format (Common Reporting Format, 2015). Separate reports on GHG emissions are produced in relation to land use, land use change and the forestry sector, which are not analysed in the dissertation (Land Use, Land Use Change and Forestry, 2015).

According to the Kyoto Protocol, Latvia had to reduce its GHG emissions by $8 \%$ in the period $2008-2012$ compared with 1990 . This commitment was successfully fulfilled by Latvia. 
According to the calculations and the NIR, agriculture produced GHG emissions of $2310 \mathrm{Gg} \mathrm{CO}_{2}$ eq in 2013, which was the second largest source of emissions in Latvia, accounting for $22 \%$ of the total non-ETS emissions. In 1990, agriculture produced GHG emissions of $5559 \mathrm{Gg} \mathrm{CO}_{2}$ eq., which represented $32 \%$ of the total non-ETS emissions. According to a projection of economic development in Latvia, agricultural GHG emissions are going to increase through 2030 , reaching $33 \%$ of the total non-ETS emissions, yet the 1990 level is not expected to be reached (SEG atlautās emisijas, 2014). In the author's opinion, such changes in agricultural GHG emissions in Latvia indicate that Latvia cannot reach its internationally set GHG reduction targets without introducing additional measures.

Based on the NIR of Latvia and employing statistical analysis methods, the author identified which anthropogenic gases $\left(\mathrm{N}_{2} \mathrm{O}, \mathrm{CH}_{4}\right.$ and $\left.\mathrm{CO}_{2}\right)$ contributed to an increase in GHG emissions from agriculture. Compared with the reference year, all the mentioned kinds of agricultural GHG emissions contributing to climate change have decreased: $\mathrm{N}_{2} \mathrm{O}$ by $46 \%, \mathrm{CH}_{4}$ by $66 \%$ and $\mathrm{CO}_{2}$ by $95 \%$; however, starting with 2005 the emissions tended to increase because of agricultural growth, see Subchapter 3.1. The largest increase was reported for $\mathrm{N}_{2} \mathrm{O}$ in 2013 - an 18\% increase from 2005.

The data on emissions are presented in Table 4.

Table 4

Agricultural GHG emissions by kind in Latvia in the period 1990-2013, Gg

\begin{tabular}{|c|c|c|c|c|c|c|c|c|c|}
\hline \multicolumn{10}{|c|}{$\mathrm{CO}_{2 \mathrm{eq}}$} \\
\hline Kind & ลे & ڤ̆ & ฮิ & ֻิ & $\stackrel{\overline{\mathrm{N}}}{\mathrm{B}}$ & $\overline{\overline{\mathrm{N}}}$ & $\stackrel{\text { בิ }}{\text { กิ }}$ & 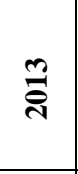 & 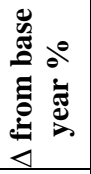 \\
\hline Nitro & 2489 & 1097 & 1016 & 1148 & 1253 & 1256 & 1325 & 1351 & -46 \\
\hline annual $\Delta, \%$ & 0 & -56 & -7 & +13 & +9 & +0.2 & +6 & +2 & $x$ \\
\hline Methane $\left(\mathrm{CH}_{4}\right)$ & 2690 & 1155 & 837 & 863 & 881 & 885 & 909 & 940 & -66 \\
\hline annual $\Delta, \%$ & 0 & -57 & -27 & +3 & +2 & +0.5 & +3 & +3 & $\mathrm{x}$ \\
\hline Carbon dioxide $\left(\mathrm{CO}_{2}\right)$ & 379 & 2 & 6 & 3 & 6 & 12 & 16 & 18 & -95 \\
\hline annual $\Delta, \%$ & 0 & -99 & +200 & -50 & +50 & +100 & +33 & +13 & $\mathrm{x}$ \\
\hline Total & 5559 & 2256 & 1860 & 2015 & 2141 & 2155 & 2251 & 2310 & -58 \\
\hline annual $\Delta, \%$ & 0 & -59 & -18 & +8 & +6 & +0.7 & +4 & +3 & \\
\hline
\end{tabular}

Source: author's construction based on the NIR, 2015

Since the use of agricultural soils contributes to the highest proportion in the total agricultural GHG emissions in Latvia, achieving the research aim requires identifying the factors that promote GHG emissions from this source. The factors of emissions and related data are presented in Table 5. 
Breakdown of the factors of $\mathrm{N}_{2} \mathrm{O}$ emissions from agricultural soils and changes in the emissions in Latvia in the period 1990-2013, Gg

\begin{tabular}{|c|c|c|c|c|c|c|c|}
\hline \multirow[b]{2}{*}{ Factor of emissions } & \multicolumn{6}{|c|}{ Year } & \multirow{2}{*}{ 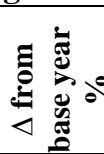 } \\
\hline & જิ & ڤ̊ & శ్రి & ஜ్ & 응 & $\stackrel{\oplus}{\vec{\sim}}$ & \\
\hline Organic soils & 2.6 & 2.6 & 2.5 & 2.5 & 2.5 & 2.6 & 0 \\
\hline annual $\Delta, \%$ & 0 & 0 & -4 & 0 & 0 & +4 & $\mathrm{x}$ \\
\hline $\begin{array}{l}\text { Application } \\
\text { fertilisers }\end{array}$ & 2.1 & 0.2 & 0.4 & 0.6 & 0.9 & 1.1 & -47 \\
\hline annual $\Delta, \%$ & 0 & -90 & +100 & +50 & +50 & +22 & $\mathrm{x}$ \\
\hline $\begin{array}{l}\text { Application of organic } \\
\text { fertilisers }\end{array}$ & 0.8 & 0.4 & 0.3 & 0.3 & 0.3 & 0.3 & -63 \\
\hline annual $\Delta, \%$ & 0 & -50 & -25 & 0 & 0 & 0 & $\mathrm{x}$ \\
\hline Manure in pastures & 0.5 & 0.2 & 0.1 & 0.1 & 0.1 & 0.2 & -60 \\
\hline annual $\Delta, \%$ & 0 & -60 & -50 & 0 & 0 & +100 & $\mathrm{x}$ \\
\hline $\begin{array}{l}\text { Crop residues in the } \\
\text { field }\end{array}$ & 0.6 & 0.3 & 0.3 & 0.4 & 0.4 & 0.6 & 0 \\
\hline annual $\Delta, \%$ & 0 & -50 & 0 & +33 & 0 & +50 & $\mathrm{x}$ \\
\hline
\end{tabular}

Source: author's construction based on the NIR, 2015

The key sources of direct $\mathrm{N}_{2} \mathrm{O}$ emissions are as follows: 1) artificial nitrogen fertilisers $(\mathrm{N}) ; 2$ ) organic $\mathrm{N}$ fertilisers (e.g. manure, compost, sewage sludge); 3) $\mathrm{N}$ accumulated in crop residues and incorporated into soil (green manure, crop residues etc.); 5) ameliorated organic soils (peat soils).

Direct $\mathrm{N}_{2} \mathrm{O}$ emissions from organic soils make up $54 \%$ and those from $\mathrm{N}$ fertilisers applied represent $23 \%$ of the total emissions from the UAA. The application of $\mathrm{N}$ fertilisers is essential in crop production. However, direct $\mathrm{N}_{2} \mathrm{O}$ emissions from the application of $\mathrm{N}$ fertilisers in the period 2005-2013 rose by $83 \%$, reaching $326.7 \mathrm{Gg} \mathrm{CO}_{2 \text { eq }}$ a year.

A regression analysis done by the authors allows concluding that the number of livestock, output and GHG emissions do not strongly correlate, as the value of $\mathrm{R}^{2}$ was considerably lower than 0.8 , which indicates that the variables did not strongly interact. Agricultural holdings engaged in livestock production comply with the legal framework for manure management. Adequate requirements imposed on farm management contribute to environment-friendly agricultural growth, thereby reducing GHG emissions.

An analysis of the statistical data on agricultural development and the impacts on the environment in the form of GHG emissions done by the author allows drawing a conclusion that crop production made the largest impact.

According to the calculations, the use of agricultural resources was not efficient. The reason, in the opinion of the author, was the exploitation of land as a resource in an inefficient way. A sustainable intensification path has to be 
chosen for development, decoupling increases in the factors of production from an increase in agricultural output.

\subsection{Projection of agricultural GHG emissions in Latvia for the period up to 2020}

In the period 2005-2015 in Latvia, agricultural GHG emissions rose by $20 \%$, and it was the second highest rate among the EU Member States behind Estonia. According to a detailed analysis of agricultural land use done by LLU, it is economically feasible to reintroduce 275 thou. ha AA into agricultural production (Pilvere I. et al., 2014). Consequently, an additional AA reintroduced into agricultural production is going to increase agricultural GHG emissions. The situation might considerably change after 2020 because, according to the new indicative target for Latvia, a $6 \%$ decrease in GHG emissions from the non-ETS sectors has to be achieved until 2030 compared with 2005 (Par mehānismu..., 2013), which, in the author's opinion, is a major challenge if taking into consideration the previous achievements. Actually, in the period 2020-2030, the allowable 17\% increase in GHG emissions from the non-ETS sectors will not be permissible, and a reduction of emissions from agriculture too has to be planned now. The previous chapters have found that crop production expands through agricultural intensification, which is true for grain production in particular. Based on an assumption that the unfarmed 275 thou. ha AA are used for crop production, the author calculates direct $\mathrm{N}_{2} \mathrm{O}$ emissions from more $\mathrm{N}$ fertilisers applied, crop residues and other emission sources.

To calculate an increase in GHG emissions, the author employed the IPCC methodology. According to the IPCC guidelines, three calculation levels of different complexity are possible. Since relatively few scientific research investigations into GHG emissions from agriculture have been done in Latvia, it is advised to employ the first level methodology (Tier 1). This methodology uses easily available statistical data and scientifically justified but generalised emission factors. In Latvia, the second level methodology (Tier 2) is employed for some kinds of GHG emissions from livestock production because there are scientifically justified regional emission factor differences (Latvia's National, 2015). Direct $\mathrm{N}_{2} \mathrm{O}$ emissions from agricultural soils are calculated according to Equation 1.

$\mathrm{N}_{2} \mathrm{O}_{\mathrm{SN} \text { Direct }}-\mathrm{N}=\left[\mathrm{N}_{2} \mathrm{O}-\mathrm{N}_{\mathrm{N} \text { inputs }}\right]=\left[\left(\mathrm{F}_{\mathrm{SN}}+\mathrm{F}_{\mathrm{AM}}+\mathrm{F}_{\mathrm{BN}}+\mathrm{F}_{\mathrm{CR}}\right) * \mathrm{EF}_{1}\right]+\left(\mathrm{F}_{\mathrm{OS}} * \mathrm{EF}_{2}\right),(1)$

where: $\mathrm{N}_{2} \mathrm{O}_{\mathrm{SN}}$ Direct- $\mathrm{N}$ - direct emissions from the application of $\mathrm{N}$ fertilisers in crop production $\mathrm{kg} \mathrm{N}_{2} \mathrm{O}-\mathrm{N}$ year ${ }^{-1}$,

FSN - amount of $\mathrm{N}$ fertilisers applied in crop production ( $\mathrm{N}$ amount), $\mathrm{kg}$ a year,

$\mathrm{F}_{\mathrm{AM}}-$ annual $\mathrm{N}_{2} \mathrm{O}$ equivalent incorporated by means of livestock manure,

$\mathrm{F}_{\mathrm{BN}}$ - amount of nitrogen accumulated by nitrogen-fixing plants,

$\mathrm{F}_{\mathrm{CR}}$ - amount of nitrogen contained by crop residues in the field,

Fos - nitrogen from tilled organic soils, 
$\mathrm{EF}_{1}-\mathrm{N}_{2} \mathrm{O}$ emission factor for $\mathrm{N}$ fertilisers applied, $\mathrm{kg} \mathrm{N}_{2} \mathrm{O}-\mathrm{N}(\mathrm{kg} \mathrm{N} \mathrm{izm})^{-1}$,

$\mathrm{EF}_{2}$ - emission factor for GHG emissions from tilled organic soils

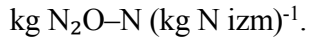

The calculated $\mathrm{N}_{2} \mathrm{O}-\mathrm{N}$ emissions from $\mathrm{N}$ fertilisers applied - have to be recalculated in $\mathrm{N}_{2} \mathrm{O}$ emissions in accordance with the 2006 IPCC guidelines according to Equation 2:

$$
\mathrm{N}_{2} \mathrm{O}=\mathrm{N}_{2} \mathrm{O}-\mathrm{N} * 44 / 28
$$

The distribution of the variable component of GHG emissions by crop group is calculated based on nitrogen fertiliser consumption.

The calculations were performed:

1) using data on the total output of crops and $\mathrm{N}$ fertiliser consumption. The approximate consumption of nitrogen fertiliser consumption was estimated for 2012 and 2020 based on proportional differences in total output;

2) distribution of the variable component of GHG emissions from soils by crop group was proportionally calculated based on the distribution of $\mathrm{N}$ fertilisers by crop group.

The reintroduced area of 275 thou. ha could additionally increase agricultural output in the range from $12 \%$ (cereals, rapeseed) to $17 \%$ (potato, meadow/pasture fresh biomass) of the total output of the respective crop in 2012 (Pilvere I., 2014). The necessary quantity of fertilisers and the additional amount of GHG emissions from every crop were calculated in proportion to the reintroduced AA. The results are shown in Table 6.

Table 6

Potential total crop production and a GHG emission projection in Latvia

\begin{tabular}{|c|c|c|c|c|c|c|c|c|}
\hline \multirow[b]{2}{*}{ Crop } & \multirow{2}{*}{ 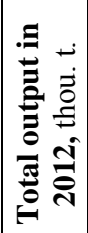 } & \multirow{2}{*}{ 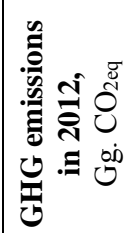 } & \multicolumn{3}{|c|}{ Reintroduced AA } & \multirow{2}{*}{ 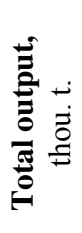 } & \multirow{2}{*}{ 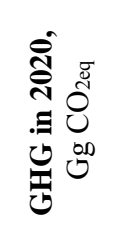 } & \multirow{2}{*}{ 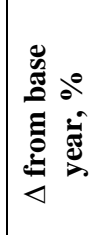 } \\
\hline & & & 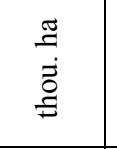 & 离 & 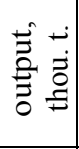 & & & \\
\hline Cereals & 2124 & 737.56 & 87197 & 16394 & 334 & 2799 & 971.88 & +32 \\
\hline Rapeseed & 303 & 212.24 & 17399 & 3268 & 46 & 373 & 260.84 & +23 \\
\hline Potato & 538 & 11.59 & 6276 & 1014 & 146 & 881 & 18.95 & +63 \\
\hline Maize & 553 & 42.46 & 3769 & 563 & 131 & 849 & 65.11 & +53 \\
\hline $\begin{array}{l}\text { Green forage/ silage } \\
\text { crops }\end{array}$ & 721 & 12.86 & 61756 & 11718 & 1292 & 898 & 68.65 & $\begin{array}{r}+533 \\
\end{array}$ \\
\hline Meadows, pastures & 167 & 1.34 & 98820 & 19098 & 833 & 478 & 36.66 & +2700 \\
\hline Vegetables & 161 & 4.77 & 0 & 0 & 0 & 195 & 5.76 & +120 \\
\hline Total & $\mathbf{x}$ & 1022.83 & 275217 & 52055 & $\mathbf{x}$ & $\mathbf{x}$ & 1427.85 & +39 \\
\hline
\end{tabular}

Source: author's construction based on Pilvere I. et al., 2014 
In case the 275 thou. ha are reintroduced into agricultural production, the variable component of GHG emissions from crop production increases by $39 \%$ in 2020 compared with 2012. Compared with the base year of 2005, the increase might reach even $80 \%$ if crop production is intensive.

D.Dougherty (1996) defines a connection between technological progress and innovation as process management, as "...innovation means creating a new concept of a product or service, its development, production and sale, while ensuring continuous process governance”. This involves setting accurate targets in agriculture and establishing an evaluation system to control the achievement of a target regarding GHG emission reduction.

\section{SUSTAINABLE INTENSIFICATION OF CROP PRODUCTION FOR AGRICULTURAL DEVELOPMENT IN LATVIA}

The chapter is 24 pages long and includes 6 tables and 11 figures.

The chapter presents a methodology for sustainable intensification assessment in crop production. The chapter assesses crop production development in Latvia.

The chapter puts forward a thesis: sustainable crop production intensification reduces negative impacts on the environment, thereby ensuring balanced development of the economic, social and natural environments.

The author believes that a method for sustainable territorial development assessment developed in the dissertation by I. Kauliņš (2015) could be applied to agriculture as well. In the author's opinion, sustainable development and an assessment of it in the national economy of Latvia has been relatively much researched, yet the impact of agricultural production expansion on the rural environment in the context of sustainability has been insufficiently researched. After performing an analysis in the chapter "Theoretical aspects of agricultural sustainable development" and an assessment of the legal act system in Chapter 2 , the author has found that in the future, an assessment of agricultural development requires employing indicators that indicate the development as a combination of economic, social and environmental aspects. Such an assessment of development is done by using a set of complex indicators that are derived based on an adequate methodology. The development of a reliable system of sustainable agricultural development indicators is needed for agricultural producers, residents as well as policy makers.

\subsection{Assessment of sustainable intensification}

On 1 July 2016, Latvia became the $35^{\text {th }}$ member country of the OECD. The development of an adequate model for assessment of sustainable agricultural development was a logical prerequisite for the membership. In the EU, an 
assessment of sustainable development is performed in relation to 10 goals, employing 11 combined indicators (Eurostat, 2015). The key EU goals for sustainable agricultural development are as follows: production of safe and healthy food; preservation of natural resources; contribution to the economic viability of agricultural holdings; enhancement of ecosystem services; development of rural environment governance; improvement of life quality in rural areas; and enhancement of welfare of agricultural animals. Indicator systems are designed and employed the most for assessment of the OECD countries. In Latvia, the Sustainable Development Strategy until 2030 has been produced and indicators showing performance, which are divided into seven categories, stressing the strategic ones, have been designed for achieving the country's sustainable development goals and assessing its performance. An assessment of sustainable agricultural development could employ indicators that show progress towards the goals "Innovative and eco-efficient economy" and "Nature as capital for future". However, in the author's opinion, the use of the indicators in a direct way for assessing sustainable agricultural intensification is not possible because there are contradictions. To assess the sustainable exploitation of natural capital, an indicator - GHG emissions - is employed; the indicator value for 2030 has to be lower than for the base year. However, the NDP indicator for agricultural land management envisages an increase against the base year (Pārresoru koordinācijas, 2015). Changes caused by development in rural areas have to be assessed in economic, environmental, social and technological terms if setting a goal to achieve sustainable crop production intensification. An assessment of sustainable intensification that shows causal associations between an increase in the standard of living, the amounts of inputs and environmental impact reductions are presented in Figure 7.

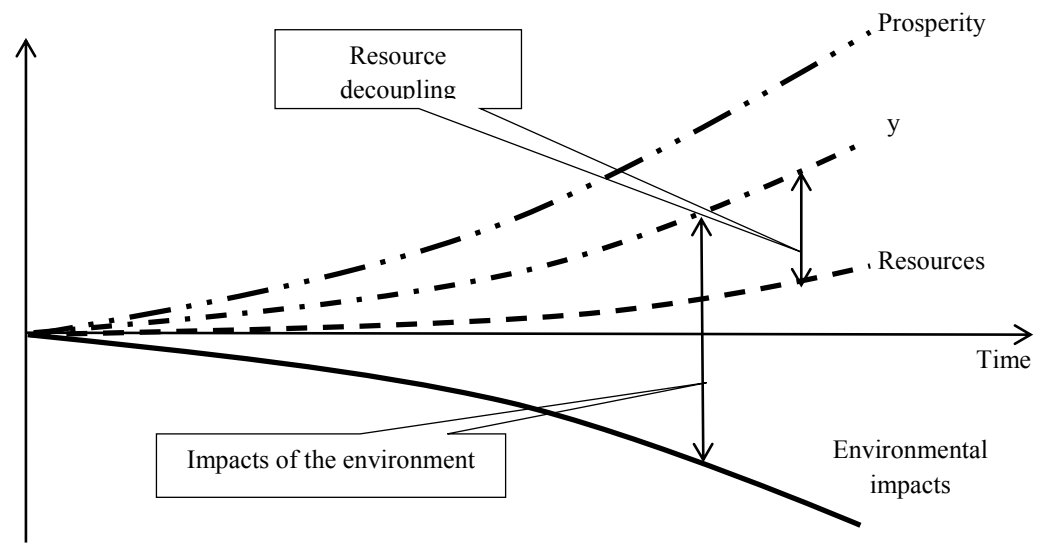

Source: author's construction based on UNEP, 2011

Fig.7. Graphic representation of an assessment of sustainable agricultural intensification 
Development has to result in synergy in order to achieve the sustainable development goals set. At the macroeconomic level, sustainable agricultural intensification has to be assessed by means of a combined, composite index that can indicate changes in every kind of capital used in production in the best way. In the present research, the author performed an assessment of sustainable crop production intensification by means of a four-step methodology: (1) identification and definition of causes of activity; (2) definition of appropriate sustainability indicators; (3) identification of indexes for sustainable intensification; (4) assessment of effects on sustainable development. Based on the definition of sustainable agricultural intensification, the author is going to identify what change dynamics the indicators of every type of capital have to represent.

The indicators of changes in the value of capital have to be: appropriate, reliable, accurate, comparable, easy to interpret and based on highquality/reliable data.

The calculation of indicators employs data on the economic activity of agricultural holdings that indicate the lowest hierarchy level in environmental, economic and social terms. Selecting an indicator, one can use: direct data (e.g. GHG emissions from crop production); a ratio or a coefficient (e.g. GHG emissions from crop production as a share of total agricultural emissions); a relative indicator (e.g. GHG emissions per gross value added in crop production).

The way of indicator selection and calculations in relation to GHG emissions into the environment is presented in Figure 8.

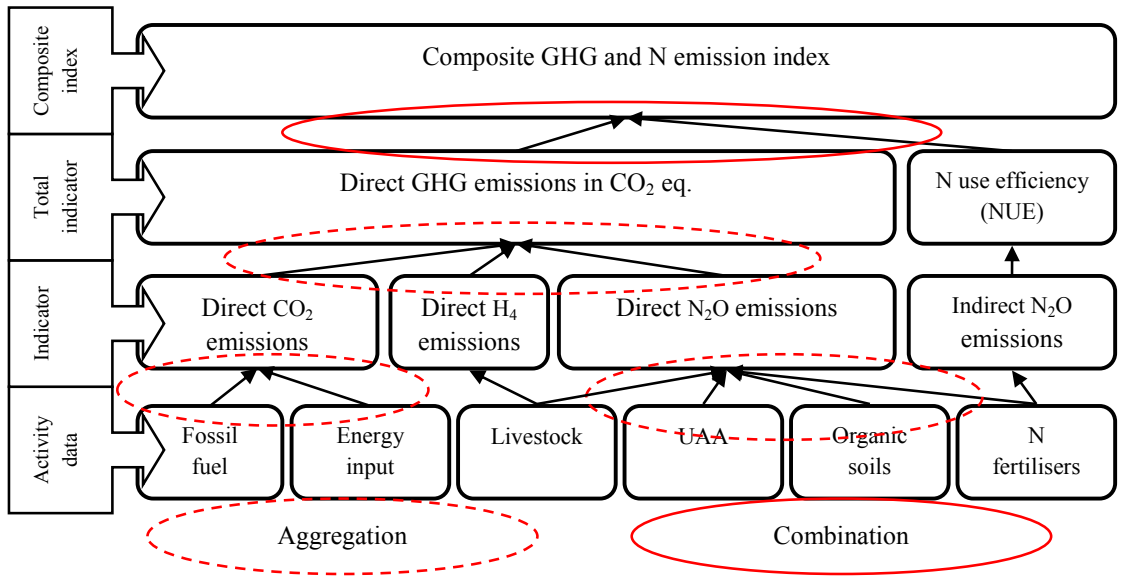

Source: author's construction

Fig.8. Sequence of the aggregation of sustainable agricultural intensification indicators for assessing the natural environment 
The indicators that indicate changes in the natural, economic and social environments in the most accurate way as well as reflect the key causal associations regarding crop production activities that make the most significant effects on sustainable intensification were selected based on the technique for indicator selection and calculation developed by the author.

The key indicator groups are as follows:

$>$ economic environment - profit margin, economic diversification, financial and resource autonomy, economic activity stability;

$>$ social environment - work and living conditions on an agricultural holding, application of good management practices, production of socially responsible products;

$>$ natural environment - fertilisation and plant protection products used, agricultural land tillage, renewable energy sources, agricultural land quality control, biodiversity, GHG emissions;

$>$ technologies/innovations - change of technological processes and equipment, product development, learning.

Under agricultural intensification, it is important to identify sustainability at the farm level. Agricultural holdings are very diverse in terms of economic size and type. Based on the calculated sustainable intensification indexes, it is possible to compare the performance of diverse agricultural holdings in terms of their social, economic, environmental as well as technological/innovation sustainability.

\subsection{Examples of the emergence of sustainable agriculture}

Growth and restructuring in crop production are directly affected by the EU strategy Europe 2020. The structural change of agricultural holdings was influenced by their engagement in the production of renewable biosources and the establishment of an economic pattern based on bioeconomic principles. The promotion of use of bioresources of agricultural origin was especially active in the period 2007-2013, which lead to the formation of a principally new industry in rural areas in Latvia, which used biomass of agricultural origin as an input. Since 2005, Latvia has a developed industry for the production of first generation bioethanol, biodiesel fuel and biogas.

Biogas is produced from: household waste - at seven biogas facilities, household sewage - at one, food production waste or wastewater - at three and agricultural commodities - at 48 biogas facilities. If considering constructing a biogas facility, it is important to be aware that the primary goal is the production of sustainable and competitive agricultural products and electricity generation from RES is only the secondary goal.

The mandatory admixture of bioethanol to fossil fuels is set at $5 \%$ in Latvia. From the perspective of legal acts, the situation in Latvia is normal. However, there are problems with biofuel sales in the market of Latvia (Lenerts A., 
2013). The use of agricultural commodities for the production of food and nonfood products is shown in Figure 9.

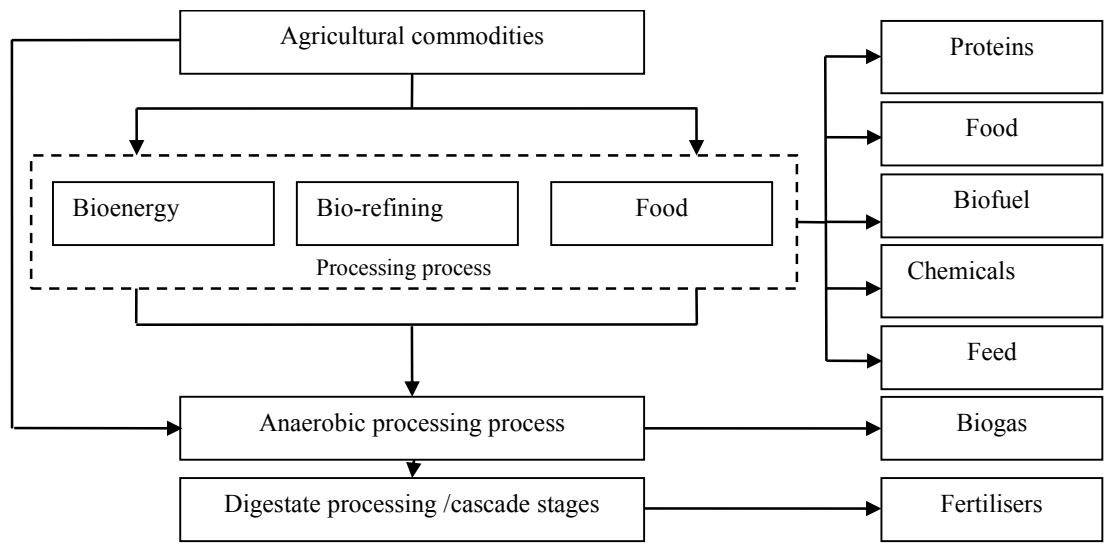

Source: author's construction

Fig.9. Sustainable agricultural production system for crops

The author wishes to draw three major conclusions that are strongly interrelated:

1. In Latvia, the biofuel production industry is insufficiently associated with the other sectors of the national economy;

2. Biofuel producers did not cooperate with national rapeseed and cereal producers and imported the inputs;

3. Despite the support measures for the industry, not a single national road transport enterprise has established a fleet of vehicles running on biofuel, unlike it is in other EU Member States.

If setting a goal to develop the bioeconomy sector and produce bio-products on farms, a question has to be answered from the perspective of prospects for business - do farmers see an opportunity to change their pattern of exploitation of their disposable resources (land, machinery, labour, knowledge) and is the production of products, which are supported to achieve political objectives, sustainable in the result of interaction of the related factors? Farmers need knowledge and an ability to comprehend and recognise the new opportunities (Cohen W.M., 1990).

\subsection{Assessment of the development of sustainable intensification of crop production in Latvia}

It is necessary to perform an assessment of agricultural production in terms of sustainability in order to adapt to sustainable development (Pope J., 2013). The assessment of sustainable crop production intensification used data for 
2005 and 2015. By employing the assessment method developed, it is possible to identify how agriculture performs after GHG emission reduction measures have been introduced, compared with a situation if no measures have been implemented.

Selecting the indicators, the author defined six key features of sustainable development:

$>$ changes in development have to be positive, oriented towards a sustainable future;

$>$ all the key factors of sustainable intensification are examined and interrelations among them are analysed;

$>$ interrelations among the economic, social, environmental and technological/innovation factors are assessed;

$>$ compromises among the factors are decreased as much as possible;

$>$ an assessment of the factor efficiency is done taking into account human needs for sustainability;

$>$ the methodology for assessment is simple and understandable for everyone involved in the system.

The author created a unified list of indicators being typical of the conditions in Latvia. In assessing the suitability of an indicator, a methodology developed by S. Bell and S. Morsi (Bell S., 2008) in their work „Sustainability Indicators: Measuring the Immeasurable?" as well as a study done in EU Member States on opportunities to employ Farm Accountancy Data Network (FADN) indicators for sustainability assessment were taken into consideration (Diazabakana A., 2016).

Based on a system for assessment of indicator levels, change in the value of any type of capital caused by the value of services and goods produced by the agricultural ago-ecosystem is assumed to be the starting point. Criteria influencing the function, based on which indicators are derived, are set for every change in the type of capital at the next stage.

The research aim set is to identify opportunities for sustainable agricultural development at the micro - or farm level, and the next stage of indicator selection involves an assessment of the potential database.

The list included 44 indicators that met the criteria for sustainability assessment. The data on farm sustainability, revealing causal associations between economic factors, were analysed for the crop farms $(n=347)$ available in the FADN database broken down by economic size.

The indicators showing causal associations between the economic, social, environmental and innovation/technological functions were selected by performing a correlation analysis.

The sequence of steps for assessment is presented in Table 7 . 
Agricultural sustainability assessment levels

\begin{tabular}{|c|c|c|c|}
\hline 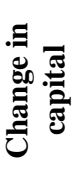 & 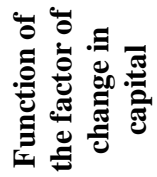 & Criterion & Indicator \\
\hline \multirow{4}{*}{ 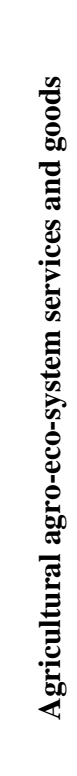 } & 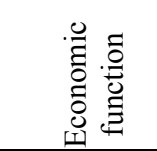 & $\begin{array}{l}\text { Farm revenue; lower dependence } \\
\text { on support payments; lower } \\
\text { agricultural production risks. }\end{array}$ & $\begin{array}{l}\text { Revenue from agricultural } \\
\text { products; share of } \\
\text { agriculture in GDP; insured } \\
\text { UAA. }\end{array}$ \\
\hline & 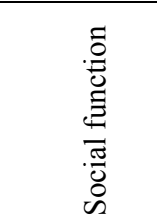 & $\begin{array}{l}\text { Enhancement of work conditions; } \\
\text { jobs in rural areas; generation } \\
\text { continuity on farms; farm } \\
\text { revenue from non-agricultural } \\
\text { activities. }\end{array}$ & $\begin{array}{l}\text { Employment in agriculture; } \\
\text { risk of abandoning } \\
\text { agricultural activity; } \\
\text { economic dependence on } \\
\text { primary agricultural } \\
\text { production. }\end{array}$ \\
\hline & 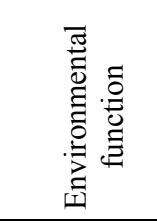 & $\begin{array}{l}\text { Preservation of biodiversity; soil } \\
\text { quality maintenance; less } \\
\text { emissions into the environment; } \\
\text { optimisation of use of fossil } \\
\text { energy resources; biotope } \\
\text { diversity maintenance. }\end{array}$ & $\begin{array}{l}\text { Type of farms; crop } \\
\text { rotation in the UAA; N } \\
\text { balance: plant protection } \\
\text { products; energy balance. }\end{array}$ \\
\hline & 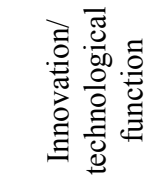 & $\begin{array}{l}\text { Agricultural products produced; } \\
\text { production technology used; new } \\
\text { knowledge gained. }\end{array}$ & $\begin{array}{l}\text { Investment in new } \\
\text { machinery; areas under } \\
\text { papilionaceous plants; } \\
\text { agricultural processing. }\end{array}$ \\
\hline
\end{tabular}

Source: author's construction based on van Cauwenbergh N. et al., 2007

The indicators showing causal associations between the economic, social, environmental and innovation/technological functions were selected by performing a correlation analysis.

The final list of indicators of sustainable intensification factors was created after performing the assessment. It consists of five indicators for each factor group: economic, social, environmental and innovation/technological.

The sustainability factors of the factors were grouped horizontally and vertically in a matrix. Every indicator was sequentially compared with the others. Every indicator's significance or weigh was calculated according to Equation 3.

$$
S_{i}=\frac{p_{\max }-p_{i}+1}{\sum_{i=1}^{13} p_{i}},
$$

where: $\quad S_{i}$ - weight of the i-th indicator, $(\mathrm{n}=1,2, \ldots, 13)$,

$P_{i}-$ number of advantages of the i-th indicator. 
The proportion of the number of every indicator's advantages shows the relative weight of the indicator in the range from 0 to 1 . Afterwards, the significance of every factor is calculated according to Equation 3. The significance (weights) of sustainable intensification indicators is presented in Table 8 .

Table 8

Weights of sustainability factor indicators for crop farms in Latvia in the period 2005-2015

\begin{tabular}{|l|l|c|}
\hline $\begin{array}{c}\text { Indicator } \\
\text { code }\end{array}$ & \multicolumn{1}{|c|}{ Indicator } & Indicator weight $\boldsymbol{S}_{\boldsymbol{i}}$ \\
\hline EK 4 & UAA productivity & 0.08 \\
\hline EK 7 & Economic diversification & 0.06 \\
\hline EK 9 & Labour productivity & 0.07 \\
\hline EK 10 & Enterprise financial stability & 0.08 \\
\hline SO 5 & Retention of jobs in rural areas & 0.06 \\
\hline SO 6 & Creation of jobs in rural areas & 0.03 \\
\hline SO 9 & Enterprise social responsibility & 0.10 \\
\hline VI 1 & Emission intensity in the agro-ecosystem & 0.10 \\
\hline VI 10 & Preservation of biodiversity & 0.10 \\
\hline VI 6 & Environment-friendly farm management & 0.04 \\
\hline TI 1 & Crop production expansion & 0.10 \\
\hline TI 3 & Innovations in production technologies & 0.10 \\
\hline TI 4 & Innovations in production systems & 0.08 \\
\hline Total: & & $\sum=1$ \\
\hline
\end{tabular}

Source: author's construction

At the next stage, the normalisation of indicators was performed, which was aimed at making the indicator values comparable. The author employed minmax normalisation, as it has a number of advantages in this particular case. This method gives positive indicator values, and farm groups are compared against the highest and lowest values, as well as the current ratio between the values is retained and the data are easy to perceive. The normalisation was done using Equation 4.

$$
R_{i}^{\prime}=\frac{r_{i}-r_{\min }}{r_{\max }-r_{\min }}
$$

where: $\quad R_{i}-$ normalised value of the $i$-th indicator, $(\mathrm{n}=1,2, \ldots, 13)$,

$r_{i}$ - real value of the $i$-th indicator, $(\mathrm{n}=1,2, \ldots, 13)$,

$r_{\text {min }}$ - minimum real value of the $i$-th indicator,

$r_{\max }$ - maximum real value of the $i$-th indicator.

The normalised values of indicators of sustainable crop production intensification were calculated for 2005 and 2015 . The normalised values, $R_{i}$, were calculated for six farm groups of diverse economic sizes for 2005 and 2015, which totally represented 347 agricultural holdings engaged in crop farming. Table 9 shows the normalised values for 2015 . 
Normalised average indicators of sustainability factors for crop farms in Latvia in 2015

\begin{tabular}{|c|c|c|c|c|c|}
\hline 营 & Indicator & $\begin{array}{l}\text { Measure } \\
\text { ment unit }\end{array}$ & 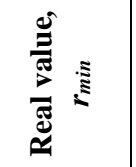 & 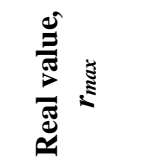 & 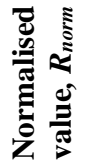 \\
\hline EK 4 & UAA productivity & EUR ha $^{-1}$ & 378.15 & 964.32 & 0.56 \\
\hline EK 7 & Economic diversification & $\%$ & 25.7 & 71.32 & 0.80 \\
\hline EK 9 & Labour productivity & $\begin{array}{c}\text { EUR } \\
\text { indiv. }^{-1}\end{array}$ & 15077.09 & 353360.58 & 0.09 \\
\hline EK 10 & Enterprise financial stability & $\%$ & 27.96 & 67.24 & 0.26 \\
\hline SO 5 & $\begin{array}{l}\text { Retention of jobs in rural } \\
\text { areas }\end{array}$ & $\begin{array}{c}\text { Indiv. } 100 \\
\text { ha }^{-1}\end{array}$ & 0.27 & 2.51 & 0.57 \\
\hline SO 6 & $\begin{array}{l}\text { Creation of jobs in rural } \\
\text { areas }\end{array}$ & $\%$ & 0.03 & 16.86 & 0.05 \\
\hline SO 9 & $\begin{array}{|ll|}\text { Enterprise } & \text { social } \\
\text { responsibility } & \end{array}$ & $\begin{array}{l}\text { EUR } \\
\text { indiv. }^{-1}\end{array}$ & 26.67 & 59.09 & 0.13 \\
\hline VI 1 & $\begin{array}{l}\text { Emission intensity in the } \\
\text { agro-ecosystem }\end{array}$ & EUR ha-1 $^{-1}$ & 47.97 & 199.84 & 0.72 \\
\hline VI 10 & Preservation of biodiversity & EUR ha $^{-1}$ & 28.44 & 112.3 & 0.57 \\
\hline VI 6 & $\begin{array}{l}\text { Environment-friendly farm } \\
\text { management }\end{array}$ & $\%$ & 0 & 27.82 & 0.26 \\
\hline TI 1 & Crop production expansion & $\%$ & 0.56 & 10.5 & 0.42 \\
\hline TI 3 & $\begin{array}{l}\text { Innovations in production } \\
\text { technologies }\end{array}$ & $\%$ & 235.67 & 540.13 & 0.75 \\
\hline TI 4 & $\begin{array}{l}\text { Innovations in production } \\
\text { systems }\end{array}$ & EUR ha-1 & 0.3 & 1.03 & 0.46 \\
\hline
\end{tabular}

Source: author's construction based on the FADN, 2015

Using Equation 5, the sustainable intensification indicator IA was calculated; the value of the indicator shows change in the economic, social, environmental and innovation/technological functions in 2005 and 2015. The calculations employed the weight and normalised value of every sustainability factor indicator. To make a comparison, an indicator is calculated for every economic size farm group employing the data for 2005 and 2015.

$$
I A_{j i}^{\prime}=\sum_{i=1}^{13} S_{i} R_{i j}
$$

where: $I A_{j}$ - sustainable intensification indicator for the $i$-th farm group, $(\mathrm{j}=1,2, \ldots, 6)$, $S_{i}$ - weight of the $\mathrm{i}$-th sustainability indicator, $(\mathrm{i}=1,2, \ldots 13)$, $R_{i j}$ - normalised value of the $i$-th indicator for the $j$ group.

Using Equation 5, the calculations employed the standardised values and weights that were used to calculate the sustainable intensification indicator. In 
calculating the IA indicator, the indicator values are summed up according to the trajectory. If an indicator shows growth, e.g. an increase in the amount of manure per ha UAA, the plus sigh $(+)$ is used, as an increase results in a higher IA value. However, if it is a decrease, e.g. a smaller amount of plant protection products per ha UAA is applied, the minus sigh (-) is used, as a decrease results in a lower IA value.

The analysed data indicate differences in development among farm groups of diverse size groups. The large farms have intensified their production, while increasing environmental impacts. With the current economic processes continuing in rural areas that result in an increase in the physical size (UAA) and the economic size of farms, negative effects on the rural environment rise, which is in contradiction to the principles of sustainability. Further, to accurately assess the development of farms, the author performs an assessment based on the methodology developed. The development indexes obtained are compared with the calculation results for 2015 , and the nature of change has to precisely indicate the trend. The calculated IA index values are presented in Table 10.

Table 10

$I A$ index values by size group of FADN crop farms $(n=347)$ in Latvia in 2005 and 2015

\begin{tabular}{|c|c|c|c|c|c|c|c|c|}
\hline \multirow{2}{*}{$\begin{array}{c}\text { Economic size } \\
\text { group, thou. } \\
\text { EUR }\end{array}$} & \multicolumn{2}{|c|}{$\begin{array}{c}\text { Economic } \\
\text { sustainability } \\
\text { index }\end{array}$} & \multicolumn{2}{|c|}{$\begin{array}{c}\text { Social } \\
\text { sustainability } \\
\text { index }\end{array}$} & \multicolumn{2}{|c|}{$\begin{array}{c}\text { Environment } \\
\text { al } \\
\text { sustainability } \\
\text { index }\end{array}$} & \multicolumn{2}{|c|}{$\begin{array}{c}\text { Innovation/ } \\
\text { technological } \\
\text { sustainability } \\
\text { index }\end{array}$} \\
\cline { 2 - 9 } & 2005 & 2015 & 2005 & 2015 & 2005 & 2015 & 2005 & 2015 \\
\hline Average farm & -0.18 & -0.12 & 0.16 & 0.14 & 0.00 & -0.25 & 0.38 & 0.46 \\
\hline $4<15$ & -0.22 & -0.30 & 0.44 & 0.38 & 0.24 & 0.24 & 0.56 & 0.00 \\
\hline $15<25$ & -0.26 & -0.20 & 0.21 & 0.38 & 0.19 & -0.03 & 0.43 & 0.19 \\
\hline $25<50$ & -0.15 & -0.31 & 0.31 & 0.24 & 0.11 & -002 & 0.33 & 0.46 \\
\hline $50<100$ & -0.24 & -0.17 & 0.03 & 0.11 & 0.13 & -0.08 & 0.34 & 0.40 \\
\hline $100<500$ & -0.12 & -0.06 & 0.12 & 0.05 & -0.11 & -0.36 & 0.35 & 0.55 \\
\hline$>500$ & 0.30 & 0.30 & 0.02 & 0.00 & -0.48 & -0.48 & 0.27 & 0.55 \\
\hline
\end{tabular}

Source: author's construction based on the FADN, 2005, 2015

The growing environmental impacts of agricultural activity are indicated by the statistical data on agriculture in Latvia analysed by the author. The calculations prove and reveal the cause of decrease in the value of the 
environmental sustainability indicator, namely, the growing consumption of fertilisers.

Changes in the indexes for the crop industry are shown in Figure 10.

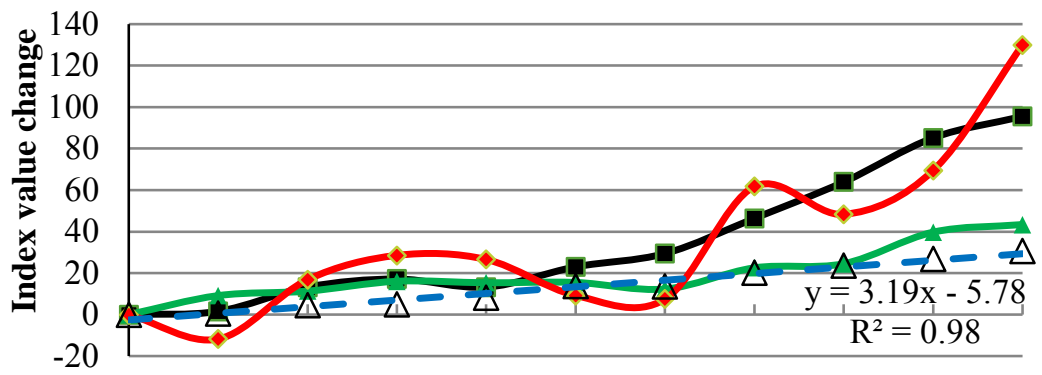

20052006200720082009201020112012201320142015

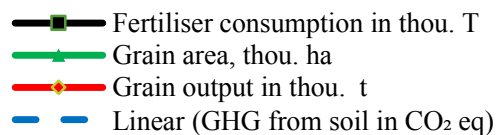

Year

Source: author's construction based on the CSB, 2016

\section{Fig.10. Crop farming indexes $(2005=100)$ in Latvia in the period $2005-2015$}

The intensification of production of key crops - cereals and rapeseed - in Latvia occurs through the growing consumption of synthetic fertilisers. GHG emissions from crop production increased by $27 \%$ in 2015 compared with the base year. The pattern of agricultural growth does not meet the principles of sustainable intensification because, according to the author's calculations, the intensity of GHG emissions is higher in the group of large farms, yet it decreases in the group of small farms (Lenerts A., 2015).

The largest increase in the fertilised area in the period 2009-2014 was reported for cereals $-29.7 \%$. A more essential factor is that fertiliser application intensity per ha under cereals rose 1.2 -fold, which contributes to GHG emissions from agricultural activity. This means that the emission reduction target is not going to be achieved.

A recalculation of $\mathrm{N}$ fertiliser $\mathrm{N}_{2} \mathrm{O}$ emissions of $1.78 \mathrm{~kg} \mathrm{ha}^{-1}$ under cereals into $\mathrm{CO}_{2}$ eq shows that the emissions are $530.44 \mathrm{~kg} \mathrm{ha}^{-1}$. At the average cereal yield of $4.03 \mathrm{tha}^{-1}$, GHG emissions per unit of output equal $131.62 \mathrm{~kg} \mathrm{CO}_{2}$ eq. To identify whether this value corresponds to the optimum GHG emission level, the next chapter aggregates EU scientist data and performs a comparative analysis.

The formation of intensive dairy farms has to be promoted by means of long-term agricultural production plans. In this way, more organic fertilisers are supplied to the growing UAA, replacing synthetic fertilisers (Lenerts A. 2015). For this reason, it is not possible to fully avoid emissions into the natural environment. However, it is possible to control the situation and contribute to 
higher fertiliser application efficiency, while reducing the costs of the factors of production as well as GHG emission intensity per unit of output and per ha UAA (Lenerts A., 2016).

\section{GHG EMISSION REDUCTION MEASURES IN CROP PRODUCTION AND AN ASSESSMENT OF THEIR EFFECTS ON THE NATURAL AND ECONOMIC ENVIRONMENTS}

The chapter is 23 pages long and includes 7 tables and 14 figures.

The chapter analyses marginal abatement costs for GHG emissions. The chapter identifies GHG emission reduction measures for crop production that are appropriate under the conditions in Latvia. It also gives a projection of GHG emissions.

The chapter puts forward a thesis: the introduction of GHG emission reduction measures in crop farming ensures the preservation of the natural environment and economic benefits from sustainable agricultural development.

Based on the author's calculations presented in Chapter 3, the reintroduction of the AA into agricultural production at the current technological level and assortment of products significantly exceeds the allowable agricultural GHG emission level for Latvia (Paris Agreement). The real GHG emission increase up to 2015 and a projection of GHG emissions until 2020 is shown in Figure 11.

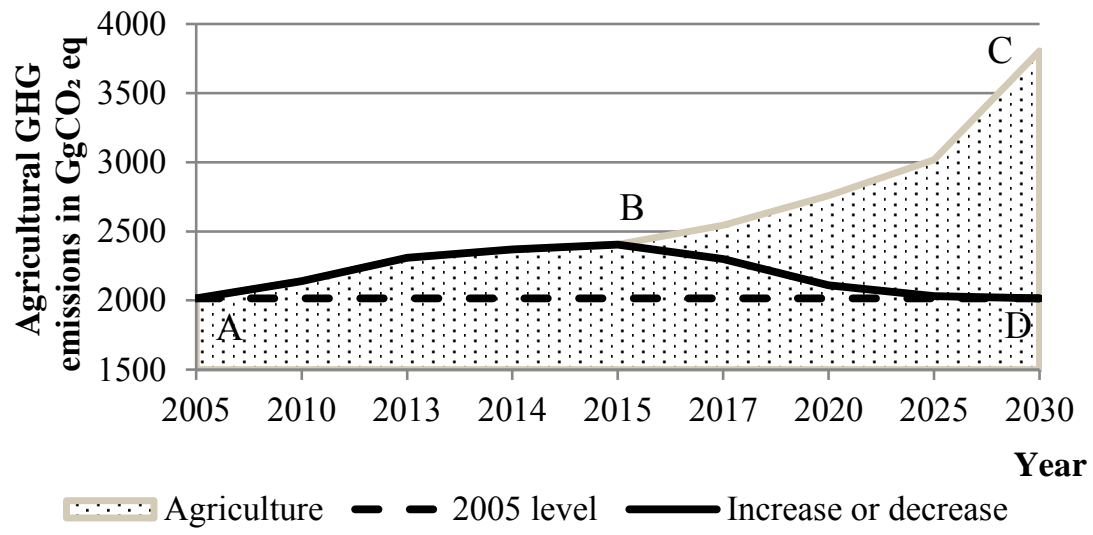

Source: author's construction

Fig.11. Agricultural GHG emissions in Latvia in the period 2005 - 2015 and an emission projection for the period up to 2030

To identify GHG emission reduction opportunities, the author performed calculations for an alternative GHG emission reduction scenario (from A to D 
as shown in Figure 11). By identifying GHG emission reduction measures appropriate for crop production, the research is going to determine the emission reduction potential in 2020. Thus, the key aim of the research is to seek opportunities for agricultural development in Latvia, while also ensuring the convergence of economic interest and environmental protection. The sustainable intensification assessment done in Chapter 4 indicates crop production growth, and economic growth simultaneously results in negative impacts on the natural and social environments, which is in contradiction to the principles of sustainability. In Chapter 5, the author performed calculations to identify causal associations and potential emission reduction measures in order that crop farms in Latvia can contribute to the symbiosis of economic growth and natural environment preservation. To achieve the aim, the following Chapter 5 research tasks were set: to explain the method of marginal abatement cost analysis; to perform a theoretical assessment of the potential GHG emission reduction measures for crop production in Latvia; to identify the emission reduction measures to be introduced by employing hierarchical (multidimensional) factor analysis; to calculate the GHG emission reduction and economic benefits-costs after the measures are introduced by applying a methodology developed by McKinsey (McKinsey..., 2010) and construct a marginal abatement cost curve, (MACC).

\subsection{Analysis of marginal abatement costs}

The method of marginal abatement cost analysis was developed for the first time in the 1970s.

Marginal abatement cost curves are widely used in agricultural analysis to identify an ability to adapt to climate change abatement (Wreford A., 2010). A marginal abatement cost curve allows:

$>$ assessing the economic efficiency of some GHG emission reduction measures, which means reducing emissions and saving financial resources, as well as gives information on what measures might be introduced under certain conditions. Cost-effective measures have "negative costs", and the measures are shown under the horizontal axis on the left. Relatively costeffective and cost-ineffective measures are shown above the horizontal axis on the right;

$>$ visually representing the GHG emission reduction potential for every measure, which is represented by the width of the corresponding graphical figure.

An assessment of the choice and introduction of the measures is hindered by the financial possibilities of existing farms, which are strongly associated with the economic size of the farms. Large economic size farms (according to the assessment done in Chapter 4) have made larger investments in the change of machinery, equipment and technologies, therefore the potential of the farms 
to reduce emissions and, at the same time, increase agricultural output, in the author's opinion, is higher.

The costs of introduction of GHG emission reduction measures for crop production are identified based on change in contribution margins of the crops (expressed as EUR $\mathrm{ha}^{-1}$ ) and calculated using Equation 6. Applying the "bottom-up" MACC construction approach, a contribution margin of every measure to be introduced is identified, which is compared with the cost of the basic scenario (LLKC contribution margin data). A model for calculating the costs and benefits of GHG emission reduction measures is shown in Figure 12.

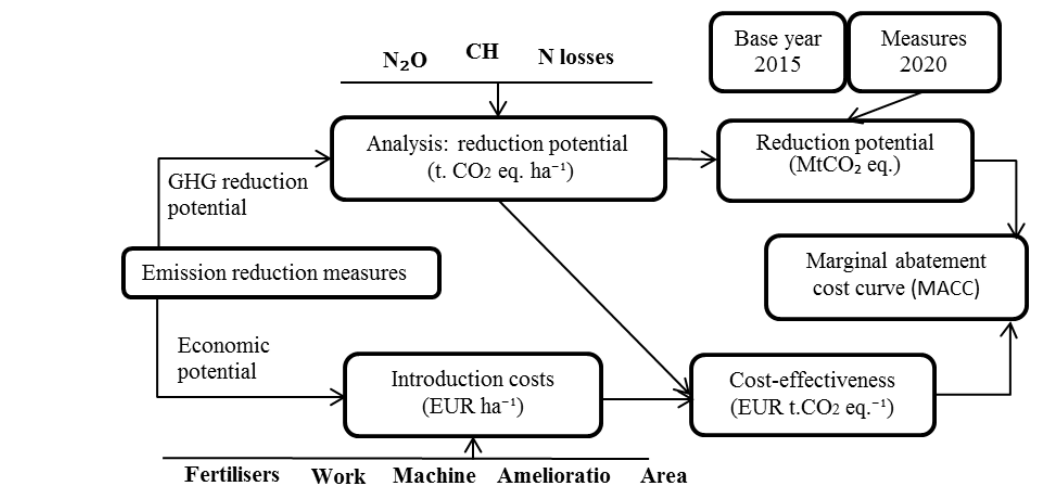

Source: author's construction

Fig.12. Model for calculating a cost and benefit curve for GHG emission reduction measures for the crop sector in Latvia

This approach ensures a possibility to compare returns of the factors of production for crop production as well as output before and after GHG emission reduction measures are introduced by using Equation 6 .

$$
\Delta B S_{p . c .}=\sum_{t=1}^{5}\left(R_{c} * C_{c} * R I_{p . c .}\right)-M_{c}-I_{p . c .}-Z_{p . c .}-B S_{c},
$$

where: $\Delta B S_{\text {p.c. }}$ - change in the contribution margin after a GHG emission reduction measure is introduced,

$T$ - measure implementation period after the introduction of the measure, $(\mathrm{t}=1,2, \ldots, 5)$,

$R_{c}-$ average crop $c$ yield,

$C_{c}$ - average crop $c$ sales price,

$R I_{p . c .}-$ increase in the average crop $\boldsymbol{c}$ yield, \%, if introducing the measure $\boldsymbol{p}$,

$M_{c}$ - variable production cost for the crop $c$ before the introduction of the measure,

$I_{p . c .}-$ cost of introduction of the measure $\boldsymbol{p}$ for the crop $\boldsymbol{c}$,

$Z_{p . c .}-$ decrease in revenue from the crop $\boldsymbol{c}$ if introducing the measure $\boldsymbol{p}$,

$B S_{c}$ - contribution margin for the crop $\boldsymbol{c}$ before the introduction of the measure.

The cost effectiveness (CE) of GHG emission reduction measures for crop production is calculated according to Equation 7. 


$$
I E_{p . c .}=\frac{\Delta B S_{p . c .}}{\Delta S E G_{p}},
$$

where: $I E_{p . c .}-$ cost effectiveness of the GHG emission reduction measure $\boldsymbol{p}$ for the crop $c$,

$\Delta B S_{\text {p.c. }}$ - change in the contribution margin for the crop $c$ if introducing the measure $\boldsymbol{p}$,

$\triangle S E G_{p}-$ GHG emission reduction if introducing the measure $\boldsymbol{p}$.

\subsection{Necessity for GHG emission reduction measures in crop production}

To identify whether economic growth in Latvia outpaces an increase in environmental impacts, exploiting the factors of production, the author calculated the intensity of GHG emissions per unit of output for the period 2009-2014.

Further in the research, the well-known production factor function - Equation $8-$ is used as a reference point.

where: $\mathrm{P}$ - output,

$$
P=f\left(x_{1}, x_{2} \ldots, x_{n}\right),
$$

$\mathrm{x}_{1}, \mathrm{x}_{2}, \ldots \mathrm{x}_{\mathrm{n}}-$ factors of production exploited.

The function shows how and how fast the resources are transformed into a final product, e.g. how many units of the corresponding $\mathrm{N}$ fertiliser have to be applied to acquire a planned crop yield or to maximise the theoretical output of the crop based on a rational cost-benefit analysis and a feasible choice. A causal association between the application of $\mathrm{N}$ fertilisers and the output of winter wheat is shown in Figure 13.

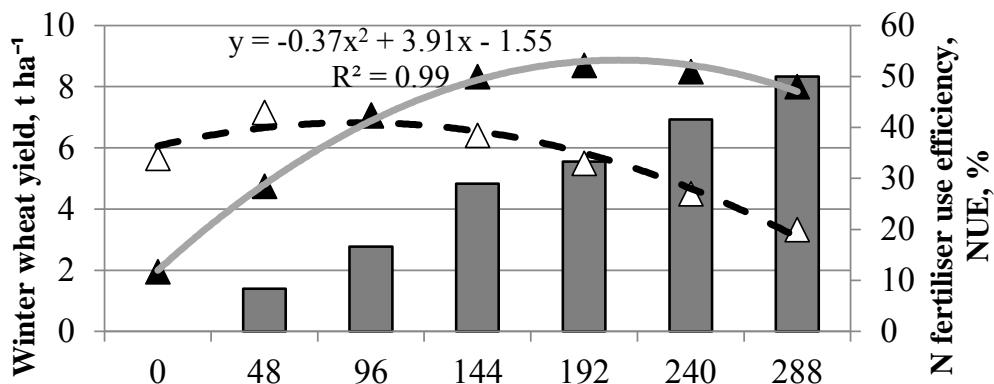

$\mathbf{N}$ fertiliser application rate, $\mathrm{kg} \mathrm{ha}^{-1}$

$\square \mathrm{N}$ application rate $\mathrm{ha}^{-1}$

\ Yield t ha ${ }^{-1}$ $\triangle$ NUE

Poly. ( Yield t ha ${ }^{-1}$ )

Source: author's construction based on Hawkesford J. M., 2014

Fig.13. Wheat yields, and fertiliser use efficiency

As long as no research investigations into GHG emissions from soils under the conditions in Latvia have been conducted, the calculations have to use the IPCC guidelines. The production of GHG emissions depends on the crop 
grown. Therefore, when making a decision on the choice of a particular crop, it is important to understand what purpose the crop grown is going to be used. In Latvia, the cropping pattern of crop farms is dominated by crops producing the highest GHG emissions per unit of output. The data included in Chapter 3 show that in 2015 , cereals occupied $35.7 \%$ of the total cropped area; the cereals usually have high GHG emission intensity. In the author's opinion, the CAP will have to introduce corrective measures to change the cropping pattern; otherwise, output will have to be reduced because of GHG emissions from the crops, which is going to hinder agricultural development. In the author's opinion, in view of the fact that the limit of sugar production is no longer in force in Latvia, it is necessary to return to a serious assessment of whether to include sugar beet in the cropping pattern because GHG emission intensity for sugar beet production per unit of output is the lowest.

At the next assessment stage, the author assessed GHG emission intensity for crop farms producing winter wheat in Latvia. The calculations used unpublished CSB data that were prepared by the CSB specialists on the author's request. The emission intensity was calculated employing the life cycle analysis (LCA) method, so that the data acquired were comparable, analysable and interpretable with the data for other countries. The indicators of GHG emissions from winter wheat production, which were calculated based on an identical methodology, for the United Kingdom (Berry P. M., 2010) and Poland (Wojcik-Gront E., 2016) were selected for comparison. GHG emission factors for wheat production were calculated in terms of $\mathrm{CO}_{2}$ eq per $\mathrm{kg}$ of output. The calculations of GHG emissions per ha of wheat area were done based on a methodology developed by P.M. Berry (2010). Employing the calculation model developed and the data acquired, GHG emission intensity was identified for winter wheat production in Latvia in the period 2009-2014. The results are presented in Figure 14.

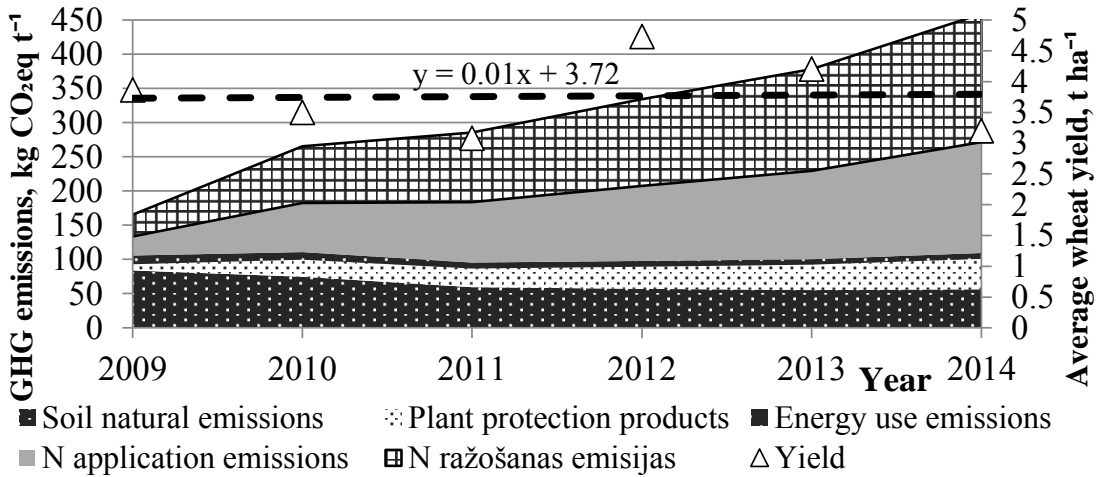

Fig.14. GHG emission intensity from the winter wheat area in Latvia in the 2009 - 2014, $\mathrm{kg} \mathrm{CO}_{2}$ eq t $^{-1}$ 
The results obtained prove the author's assumption that there are no opportunities for further agricultural development without additional GHG emission reduction measures. GHG emissions have increased by $250 \%$, reaching $450 \mathrm{~kg} \mathrm{CO}_{2} \mathrm{eq} \mathrm{ha}^{-1}$. In turn, the average increase in cereal production is $0.01 \mathrm{t}$. ha ${ }^{-1}$. Latvia as one of the EU Member States is committed to react on climate change and reduce its GHG emissions. Research investigations done in the world (Repetto R. et al., 2010) confirm that with the current technologies being used, GHG emissions could be reduced by $80 \%$ through 2050 , while making no significant effect on economic growth.

The key findings of the research investigations are as follows:

$>$ it is important to use the so-called cap and trade regimes that contribute to market opportunities for "regaining" equilibrium, which determine where and when to reduce the emissions;

$>$ strategic investment in infrastructure and institutional change considerably promote progress in low carbon technologies;

$>$ it is important to create advantages for low-cost carbon-fixation measures by using national and international support programmes.

The agriculture of the EU does not belong to the non-ETS sector, therefore the first finding that envisages the introduction of a market mechanism could not be used in a direct way. The remaining two findings are essential, especially in relation to carbon fixation measures. With regard to agricultural GHG emission reduction, foreign researchers (Smith P. et al., 2008) suggest three priorities:

$>$ emission reduction - this mechanism relates to the application of effective GHG emission reduction techniques;

$>$ carbon fixation enhancement - this mechanism involves the reduction of loss of carbon accumulated in the organic part of soil. It represents land management solutions that increase the amount of carbon assimilated through photosynthesis and avoid the release of the accumulated carbon into the atmosphere;

$>$ replacement or supplementation of emission-producing agricultural practices with climate-friendlier practices - this mechanism relates to the use of plants and agricultural waste for renewable energy generation, e.g. biogas, bioethanol or biodiesel fuel production.

The author performed a comparative analysis of GHG emission reduction measures, using earlier research investigations done abroad and the measure selection criteria defined by the author:

$>$ introduction of a measure does not considerably change the agricultural production system on farms;

$>$ after the introduction of the measure, it is possible to identify the introduction cost and the reduction of GHG emissions from the farm;

$>$ data acquired could be generalised and attributed to the entire agricultural sector. 
When identifying the measures that could reduce agricultural GHG emissions, it is important to select those whose introduction considerably affects the variables used in the GHG emission calculations. Any GHG emission measure has to make a sufficient effect to be included in the NIR and meet the following criteria:

$>$ efficiency of the measure has to be proved and scientifically justified (research papers published in scientific proceedings);

$>$ reduction effect of the measure could be used in the GHG calculation methodology employed to produce a NIR (e.g. peatland (histosol) areas for crop production);

$>$ indicators for the control of the measure have been defined (e.g. nitrogen fertiliser use efficiency, NUE);

$>$ introduction of the measure does not considerably change the agricultural production system on farms;

$>$ it is possible to identify the introduction cost and the reduction of GHG emissions from the farm.

An examination of the situation with the classification of GHG emission reduction measures allows dividing the GHG measures into two priority categories in Latvia:

$>$ GHG emission reduction measures to be introduced in crop production;

$>$ GHG emission reduction measures to be introduced in livestock production.

At the initial stage of the examination, a long list of measures was created; afterwards, based on an evaluation by experts in crop and livestock production as well as taking into consideration the conditions in Latvia, 19 GHG emission reduction measures to be implemented in field crop production were identified (National Research..., 2016). The author divided these measures into five alternative groups for the purpose of tackling the problem of GHG emission reduction in crop production. Group 1 includes the measures that contribute to precision nitrogen management. Group 2 relates to the potential fixation of free nitrogen by means of, for example, growing papilionaceous plants. Group 3 measures contribute to carbon accumulation in soil through enhancing the physical and chemical properties of soils. Group 4 measures involve intensive development of organic farming. Group 5 measures, however, relate to agricultural production intensity reduction that could be achieved by growing permanent grasses in organic soils and planting fast-growing tree species in agricultural land.

\subsection{GHG emission reduction measures appropriate for the conditions in Latvia in crop production}

The research employed the experience and expertise of experts in order to comprehensively assess potential barriers to the introduction of selected GHG emission reduction measures in agriculture. The author processed the data 
acquired in the survey of experts by means of American mathematician $\mathrm{T}$. Saaty's Analytic Hierarchy Process (AHP) (Saaty T., 1981).

A four-level hierarchy was designed to adjust the algorithm of the AHP method to an assessment of GHG emission reduction measures for the crop sector in the agriculture of Latvia. At the first level of the hierarchy, an overall goal is set - the introduction of GHG emission reduction measures in crop production. At the second level, the experts evaluated the economic, social, environmental and technological factors affecting the achievement of the goal. At the third level, the experts set the significance of criteria affecting every factor in relation to the goal to be achieved. The experts evaluated the economic factors based on a number of criteria: available total EU CAP support funding; change in the number of jobs on farms; economic viability of agricultural holdings; financial possibilities of agricultural holdings; and effects of GHG emission reduction measures on agricultural output (Figure 15).

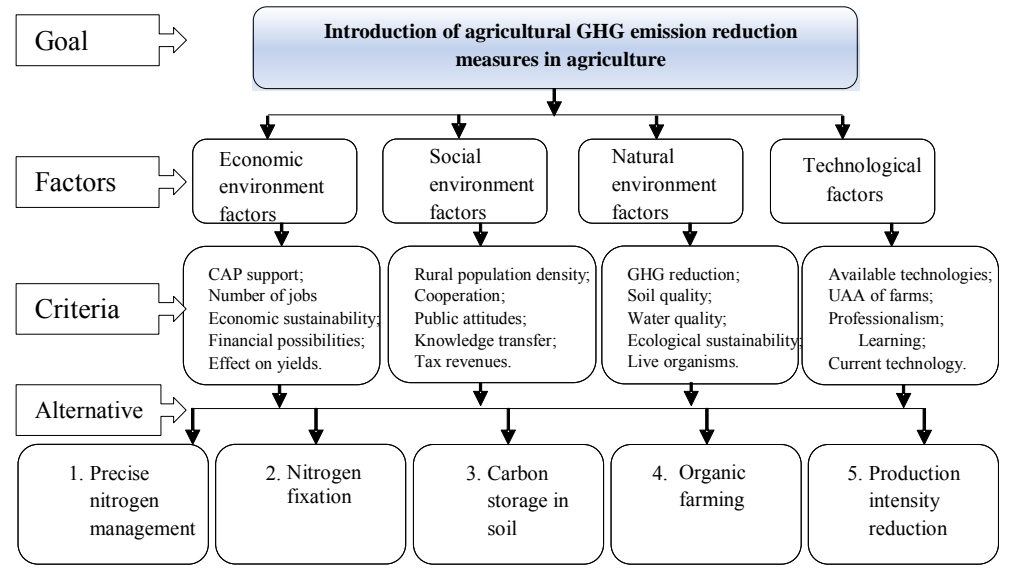

\section{Source: author's construction}

\section{Fig.15. Hierarchy for assessing GHG emission reduction measures}

The social factors were evaluated based on the following criteria: change in population density in rural areas; cooperation among agricultural holdings; influence of the society and public organisations on farm owner/manager learning; and taxes paid by agricultural holdings into the local government's budget.

The environmental factors were evaluated based on the following criteria: potential reduction of GHG emissions; increase in the values of soil qualitative indicators; increase in the values of water qualitative indicators; ecological sustainability of agricultural production; and reproduction of live organisms and species.

The technological factors were evaluated based on the following criteria: availability of the latest technologies; the utilised agricultural area of the farm; 
professional knowledge; current technology and learning. At the fourth level, the experts were given five alternatives to how to solve the problem. The alternatives were developed by grouping the GHG emission reduction measures by an indication of how to achieve the reduction effect.

The first potential alternative - precision nitrogen management, which could be achieved by: precision fertiliser application; introduction of integrated farming practices; direct incorporation of fertilisers into soil; use of nitrification inhibitors; fertilisation planning and soil liming. The second potential alternative - nitrogen fixation that could be achieved by: increase in the area under papilionaceous plants; growing papilionaceous intercrops (for nitrogen fixation); growing green manure crops in bare fallows; increase in the productivity of crops for fresh biomass. The third potential alternative - carbon accumulation in soil that could be achieved by: enhancement of the physical and chemical properties of soils; limited removal of crop residues (straw) from the field; conservation tillage and the maintenance of amelioration systems. The fourth potential alternative - intensive development of organic farming. The fifth potential alternative - lower production intensity that could be achieved by: growing permanent grasses in organic soils; planting fast-growing tree species in agricultural land.

The achievement of the research aim requires choosing adequate and competent experts. The following economic experts were involved:

1. Arnis Burmistrs - a member of the executive board of the Farmers Parliament of Latvia, the owner of the farm Vilcini,

2. Gatis Berziņš - chairman of the executive board of Precision Farming Ltd, Agricon.

The experts in the social field were as follows:

3. Oskars Balodis - head of the Crop Farming Department, Latvian Rural Advisory and Training Centre (LLKC).

4. Agate Zâlīte - a public relations specialist from the Public Relations Department of the RSS.

The experts in the environmental field were as follows:

5. Agita Gancone - senior official, Ministry of Environmental Protection and Regional Development of the Republic of Latvia.

6. Laima Bērzina - Dr. sc.ing., a leading researcher at the Department of Environmental Engineering and Water Management, LLU.

The experts in the innovation/technological field were as follows:

7. Pēteris Rivža - Dr. habil. sc. ing., a professor and a leading researcher at the Department of Computer Systems, LLU.

8. Dzidra Kreišmane - Dr. agr., an associate professor and a leading researcher at the Institute of Agrobiotechnology, LLU.

All the experts' ratings were aggregated, calculating the arithmetic mean and dispersion. In a graphical representation, dispersion is shown as a range from the maximum to the minimum for the numerical values of every particular 
evaluation. As shown in Figure 16, the experts representing the environmental and economic fields gave quite similar ratings to the environmental factors, prioritising the economic factors $(0.38)$.

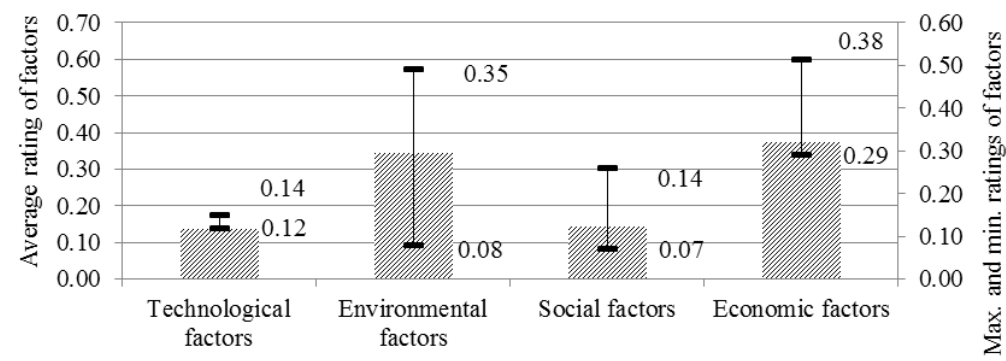

\% Mean - Max. - Min.

Source: author's construction

Fig.16. Expert evaluation of natural, social, economic environment and technological factors for the introduction of agricultural GHG emission reduction measures

However, the relatively high dispersion with regard to the environmental factors indicates that there was some disagreement in the expert opinions on the significance of the factors. The highest agreement among the experts existed in relation to the role of the technological factors $(0.14)$, which is indicated by the low dispersion of ratings.

To identify which alternative group of GHG emission reduction measures, based on the experts' ratings, has to be used in further calculations, the author analysed the experts' ratings according to all the 20 criteria.

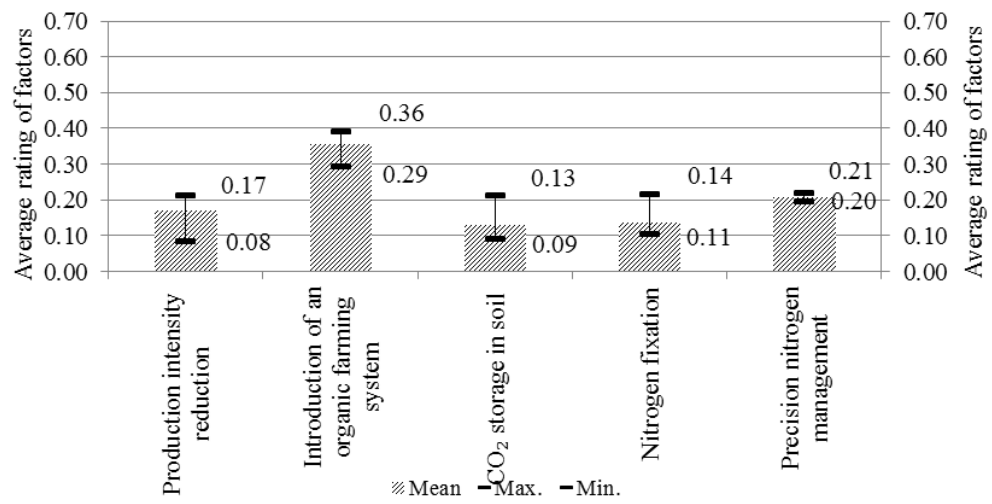

Source: author's construction

Fig.17. Expert evaluation of alternative agricultural GHG emission reduction measures

As regards the alternative groups of GHG emission reduction measures, no significant agreement existed among the experts on the measures, the 
introduction of which is associated with production intensity reduction, the introduction of an organic farming system, nitrogen fixation and $\mathrm{CO}_{2}$ storage in soil. This means that the experts had different opinions. The lowest rating was given to the third group of GHG emission reduction measures $-\mathrm{CO}_{2}$ storage in soil $(0.13)$. The second lowest rating was given to the measure group "nitrogen fixation". The experts gave the highest rating to the measure "introduction of an organic farming system", yet its ratings were the most contradictive, as shown in Figure 17.

The highest agreement among the experts was observed in relation to the measure group "precision nitrogen management". The author wants to stress that the experts' opinions on this measure group were almost the same, and one can assert that there was unanimity, which indicates the need to develop an efficient system for land resource use, including the application of fertilisers.

Since the highest agreement among the experts pertained to precision nitrogen management, the author performed cost-benefit calculations for this particular group of GHG emission reduction measures. The next group the calculations were performed for was the measure "introduction of an organic farming system" in Latvia. However, in the author's opinion, this priority could considerably affect economic growth opportunities for agriculture, as organic produce is significantly more expensive. In Latvia, the intensive introduction of an organic farming system could be implemented only after performing a precise qualitative assessment of the UAA and identifying the best functional use of the UAA.

\subsection{Cost and benefit calculations for the GHG emission reduction measure „Precision nitrogen management” in crop production}

Measure introduction costs (expressed as EUR ha ${ }^{-1}$ UAA) were calculated using Equation 9 and based on the changes in: crop yields, production costs (fertilisers, pesticides, seed etc.), labour input and machinery cost, comparing the crop farming practice according to the basic scenario or the "old way" of management for every land ha and crop used in crop production. By applying the "bottom up" approach, it was assumed that agricultural holdings, seeking to maximise their revenues and profits, are going to face certain constraints in their development and, using this approach, one can assess the change in production processes before and after introducing GHG emission reduction measures on the agricultural holdings. For this reason, it is assumed that changes in the exploitation of the factors of production tend to go up rather than down in case optimisation (reduction) is performed for the inputs: fertilisers, plant protection products, labour, land and other resources, which is usually specific to the "top down" calculation method.

To identify the cost for every measure to be introduced, the author used the statistical data that represented average costs for agricultural holdings in Latvia. The calculations employed the indicators that pertain to only the 
exploitation cost of the factors of production that are used by farms. The calculations of the indicators employed contribution margin data for every field crop aggregated by LLKC (www.new.llkc.lv). It means that the LCA approach, which takes into account GHG emissions from fertiliser production, was not used by the present research. In addition, the calculations did not use the costs and benefits of services produced by agro-ecosystems. The author did not include the support mechanism for the introduction of measures used by the CAP in the cost-benefit analysis, which involves, for example, additional payments for every ha UAA used to comply with the greening requirements. The author made an assumption that decisions made by agricultural holdings on the introduction of GHG emission reduction measures are associated with change in the behaviour of farmers themselves, which results in more efficient use of production resources. The efficiency of every measure to be introduced depends on activities done to achieve the GHG reduction target. The introduction of some measures for the area under only one crop does not ensure the achievement of total reduction potential. Therefore, it is important to understand interrelations among individual activities. N, P and $\mathrm{K}$ fertilisers are an essential factor that determines the harvest and quality of crops (Goulding K....2007).

After aggregating the above-analysed GHG emission reduction measures for precision nitrogen management, the author calculated the emission reduction potential for the crops grown in Latvia per ha UAA, which is presented in Table 11.

Table 11

Potential reduction of GHG emissions from the cropped area, $\mathrm{t} \mathrm{CO}_{2} \mathrm{eq} \mathrm{ha}^{-1}$

\begin{tabular}{|c|c|c|c|c|c|c|c|c|}
\hline \multirow[b]{2}{*}{ 节 } & \multicolumn{7}{|c|}{ GHG reduction potential for cropped areas, $\mathrm{t}^{\mathrm{CO}_{2}} \mathrm{eq} \mathrm{ha}^{-1}$} & \multirow[b]{2}{*}{ 晜 } \\
\hline & Uై & 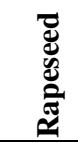 & 选 & 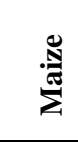 & 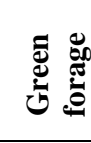 & 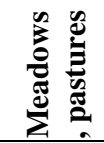 & $\sum_{0}^{\overline{0}}$ & \\
\hline SA 1 & 0.35 & 0.45 & 0.25 & 0.40 & 0.35 & 0.35 & 0.50 & 0.41 \\
\hline SA 2 & 0.20 & 0.20 & 0.20 & - & - & - & 0.20 & 0.20 \\
\hline SA 3 & 0.07 & - & - & - & 0.07 & 0.07 & - & 0.07 \\
\hline SA 4 & 0.17 & - & 0.27 & - & - & - & 0.36 & 0.27 \\
\hline SA 5 & 0.12 & 0.12 & 0.12 & 0.12 & 0.12 & 0.12 & 0.12 & 0.12 \\
\hline SA 6 & 0.04 & 0.04 & 0.04 & 0.04 & 0.04 & 0.04 & 0.04 & 0.04 \\
\hline $\begin{array}{c}\text { Area in } \\
\text { 2020, } \\
\text { thou. ha }\end{array}$ & 759.6 & 106.4 & 31.4 & 29.27 & 400.27 & 747.12 & 8.1 & $\begin{array}{c}\text { Total } \\
\text { area } \\
2082.16\end{array}$ \\
\hline
\end{tabular}

Source: author's construction based on Eory V., 2015; MacLeod M., 2015

The application of recommended rates of $\mathrm{N}$ fertiliser in particular does not ensure adequate crop yields and, according to research studies, GHG emissions increase if no precision $\mathrm{N}$ management is practised by farms. The efficiency of 
application of recommended rates of $\mathrm{N}$ fertiliser is characterised by the $\mathrm{N}$ balance and nitrogen use efficiency (NUE).

The potential reduction of GHG emissions could be achieved if:

$>$ nutrients are balanced in soil;

$>\mathrm{N}$ fertiliser is applied to meet the real needs of crops;

$>\mathrm{N}$ fertiliser is applied taking into consideration photosynthesis in plants, soil temperature and moisture.

The basic purpose of precision $\mathrm{N}$ management is to identify the necessary fertiliser rate for every parcel of a field as accurately as possible. This means that no average qualitative indicators of soil fertility are used; instead, the indicators are determined for as small parcel of a field as possible. The key advantages of it are as follows: 1) increase in the output of a crop by means of precision fertilisation; 2) decrease in inputs if not fertilising the parcels of a field having enough nutrients and not applying fertilisers when no photosynthesis occurs in plants; 3) economic benefits - higher profit margins; 4) environmental/ecological benefits - field parcels with enough nutrients are not over-fertilised and there are no $\mathrm{N}_{2} \mathrm{O}$ emissions from the fertilisers plants cannot absorb.

The cumulative approach was usually applied to the identification of emission reduction potential in the construction of MAC curves in the examples analysed by the author, assessing the effects of interaction of individual measures. The author also employed such an approach to avoid the double calculation of potential emission reduction. The effects of interaction of individual measures are expressed as a factor that takes into account the factors of interaction; the maximum value of it is 1 (one). The total GHG emission reduction due to the interaction of two measures is calculated according to Equation 9:

$$
S E_{k, i}=\left(S E_{k}+S E_{i}\right) * M E_{k-i},
$$

where: $\quad S E_{k, i}-$ total GHG emission reduction due to the $k$-th and $i$-th measures;

$S E_{k}$ - GHG emission reduction due to the $k$-th measure, $(\mathrm{k}=1,2, \ldots, 6)$,

$S E_{i}-$ GHG emission reduction due to the $i$-th measure, $(\mathrm{i}=1,2, \ldots, 6)$,

$M E_{k-i}$ - emission factor showing GHG emission reduction due to the interaction of the $k$-th and $i$-th measures.

The emission factors for the crop sector are assumed based on Scottish scientist V. Eory's assumptions and calculations. The application of the reduction measure SA6 (soil liming) increases GHG emissions, but liming improves the utilization efficiency of $\mathrm{N}$. In the calculations, the interaction coefficient is used, and in Figure 18, a separate SA6 reduction effect is not depicted.

The total GHG emission reduction potential is achieved if precision nitrogen management is practised at all stages of introduction of a measure. The initial research data on crop farms indicate that the most important activity to be done by the farms is agrochemical tests. Optimum and balanced 
qualitative characteristics of soil ensure fast plant growth, absorption of nutrients, a stable harvest and increase in yields at lower nitrogen fertiliser application rates. The most important quality characteristic of wheat intended for exports is protein content. Grain prices depend on the quality characteristics of grain (the average price of food-grade wheat was EUR $156.13 \mathrm{t}$ and that of feed-grade wheat was EUR 131.21 t, Latraps, 2015).

Grain producers who focus on grain exports have to produce wheat with a protein content of $12-13.5 \%$. Such a protein content could be achieved if growing highly productive, intensive wheat varieties and applying adequate nitrogen fertiliser rates. It is important to observe the recommended crop rotation in a field, as papilionaceous plants and microorganisms fix atmospheric $\mathrm{N}$ and turn it into ammonia. The rhizobia living on the roots of papilionaceous plants can fix $100-300 \mathrm{~kg} \mathrm{~N} \mathrm{ha}^{-1}$ year. If planning a winter wheat yield of $6-7 \mathrm{t} \mathrm{ha}^{-1}$ with a protein content of $12-13.5 \%$, the wheat plants need $180-220 \mathrm{~kg} \mathrm{~N} \mathrm{ha}^{-1}$. If the organic matter content of soil is $2-3 \%$, assuming there is a normal vegetation period, winter wheat plants are going to absorb up to $120 \mathrm{~kg} \mathrm{~N} \mathrm{ha}^{-1}$ from soil. The additional amount of $80-100 \mathrm{~kg} \mathrm{~N}$ per ha have to be supplied by means of fertilisers. A nitrogen assimilation rate for fertilisers might be, on average, $55-60 \% ; 150-170 \mathrm{~kg} \mathrm{~N}$ per ha have to be incorporated into soil. Precision $\mathrm{N}$ fertiliser application controlled by the GPS allows considerably raising the assimilation rate.

Figure 18 shows the total GHG emission reduction potential and the costs of introduction of the emission reduction measures in crop production that contribute to precision $\mathrm{N}$ fertiliser management.

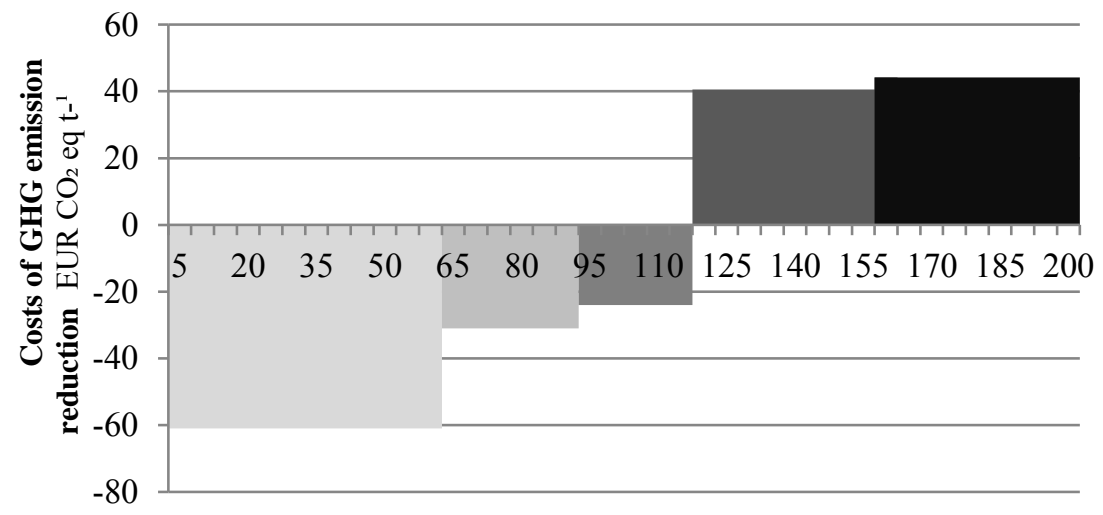

Reduction of GHG emissions from crop production $\mathrm{CO}_{2}$ eq

$\square$ Precision fertiliser application SA 1

Fertilisation planning SA 5

a Compulsory introduction of integrated farming SA 2 Direct incorporation of fertilisers into soil SA 3

- Use of nitrification inhibitors SA 4

Source: author's construction

Fig.18. Potential for and cost of GHG emission reduction measures under precision nitrogen management in crop farming in the period $2015-2020$ 
The GHG emission reduction in crop production and a decrease in inputs or cost savings for farms are ensured by precision $\mathrm{N}$ fertiliser management, fertiliser application planning and the compulsory introduction of integrated farming. The direct incorporation of fertilisers into soils and the use of nitrification inhibitors also contribute to the reduction of GHG emissions from crop production, yet the mentioned measures are cost negative due to relatively high costs of introduction of the measures, as they make negative contribution margins. In the period 2015-2020 in Latvia, it is possible to reduce GHG emissions from crop production by $205 \mathrm{t} \mathrm{CO}_{2}$ eq if introducing the precision $\mathrm{N}$ fertiliser management measures in crop production.

\section{MAIN CONCLUSIONS}

1. The sustainable use of natural resources (land) and economic growth and development could be achieved by reducing potential negative impacts on the natural, social and economic environments, expressing it in terms of change in the quantitative and qualitative indicators of natural, financial, manufactured and human capital.

2. In 2015, agricultural productivity in Latvia was the lowest among the EU Member States, lagging behind the Netherlands 16.2-fold and the EU average 5-fold. Gross national income in agriculture per capita in Latvia was 2.6-fold lower than that in the Netherlands and 1.5-fold lower than the EU average.

3. Until 1999, agricultural growth in Europe and the world was promoted by intensification, mainly by the growing application of fertilisers, which made environmental impacts and reduced the value of natural capital.

4. The total economic value (TEV) method, which allows identifying change in the value of an agro-ecosystem or natural capital, has to be employed to identify the impact of economic growth on the natural environment.

5. Starting with the year 2000, agricultural growth occurred in Europe and the world mainly based on the principles of sustainable development, reducing the negative external impacts on the economic, social and natural environments.

6. The bioeconomy represents the exploitation of bioresources accumulated by agriculture, forestry and aquaculture aimed at shaping an innovative economy that produces low $\mathrm{CO}_{2}$ emissions and creates a balance among such factors as sustainable agriculture and fisheries, the supply of food and the use of renewable biological sources in manufacturing, thereby creating new jobs, while contributing to biodiversity and environmental protection.

7. Agriculture in the EU is the most politically regulated industry, and the EU strategy Europe 2020 has set a goal to reduce GHG emissions by $20 \%$ as well as to increase the share of energy production from RES to $20 \%$ and to 
achieve a $20 \%$ increase in energy efficiency in comparison with the 1990 level. Agriculture plays an essential role in achieving the targets.

8. An analysis of the EU CAP for the period 1960-2016 shows that its focus has shifted from increase in productivity (1960) to increase in competitiveness (1980), a synergy between agricultural production and environmental preservation (1992) and rural policy effectiveness (2000).

9. In accordance with the Convention on Climate Change, which was adopted in 1992, and the Kyoto protocol, which was ratified by the Saeima of the Republic of Latvia, Latvia has assumed an obligation to reduce its GHG emissions from the non-ETS sectors by 5\% in 2030 compared with 2005 according to the target set by the Paris Agreement in 2016.

10. Change in the economic processes of agricultural holdings is characterised by structural change in their type (the number of mixed farms declines), their economic size (the number of large farms increases), their utilised agricultural area (the arable land area increases) and their farming pattern (the number of organic farms increases).

11.In 2014, there were almost 83 thou. agricultural holdings in Latvia; their number decreased by $39 \%$ compared with 2005 and by $54 \%$ compared with 1996. In 2013, the breakdown of farms by type in terms of value of output was as follows: $51 \%$ crops, $35 \%$ livestock and $14 \%$ mixed (crops and livestock). The average UAA of an agricultural holding increased by $48 \%$ in 2013 compared with 2005 and reached 24 ha. Economically efficient farms are sized, on average, $503 \mathrm{ha}$, while small ones are, on average, 9.3 ha UAA in size.

12.The largest contribution to increase in $\mathrm{GHG}$ emissions from crop production in Latvia is made by $\mathrm{N}_{2} \mathrm{O}$. Its sources are nitrogen fertilisers $(23 \%)$ and organic soils (54\%), accounting for $77 \%$ of total emissions in Latvia in 2014. The emissions increased by $83 \%$ in the period 2005-2014, contributing to the total increase in GHG emissions.

13.The application of nitrogen fertilisers is essential to reintroduce the unfarmed agricultural area into agricultural production. The regression analysis done by the author confirms that an increase in the application of nitrogen fertilisers is strongly associated with the output of crop products as well as an increase in agricultural GHG emissions, thereby increasing the negative impact on the environment.

14. To contribute to sustainable agricultural development that is based not only on growth, four main criteria have to be met: 1) the condition of the system has to be identified, described and assessed; 2) the development of the system and the achievement of the goal of it have to be projected; 3 ) information on the efficiency of activities performed has to be disclosed; 4) social groups have to be informed. An assessment of sustainable intensification in crop production is done using a four-step methodology: (1) identification and definition of causes of activity; (2) definition of appropriate sustainability indicators; (3) identification of indexes for 
sustainable intensification; (4) assessment of effects on sustainable development.

15.The calculations of crop production growth for the period 2005-2015 and the GHG emission indexes show that a considerable increase in the output of crops occurred in the period of analysis; however, it was achieved not meeting the conditions of crop production sustainability, particularly by economically large farms.

16.In the period 2005-2015 in Latvia, agricultural GHG emissions and a projection of the emissions through 2030 indicate a growing trend, which exceeds the allowable increase of $17 \%$ for the non-ETS sector by $39 \%$.

17.Applying the "bottom-up" MACC construction approach, a contribution margin of every measure to be introduced is identified and compared with the cost of the basic scenario (LLKC contribution margin data). A MAC curve allows assessing the economic feasibility of individual GHG emission reduction measures and gives information on what measures might be introduced under certain conditions.

18.The annual GHG emission reduction potential for the cropped area for the measure "precision nitrogen management" is $0.45 \mathrm{t} \mathrm{CO}_{2}$ eq ha ${ }^{-1}$. On an experimental farm, precision $\mathrm{N}$ management allows achieving a winter wheat yield of $6.4 \mathrm{t}$. ha $\mathrm{ha}^{-1}$ by applying $82 \mathrm{~kg} \mathrm{~N} \mathrm{ha}^{-1}$. Achieving a winter wheat yield of $6.5 \mathrm{t} . \mathrm{ha}^{-1}$ on a farm with no precision $\mathrm{N}$ management requires applying $188 \mathrm{~kg} \mathrm{~N} \mathrm{ha}^{-1}$. A reduction of direct and indirect emissions from $\mathrm{N}$ fertiliser savings is equal to $1696 \mathrm{~kg} \mathrm{CO}_{2}$ eq. ha ${ }^{-1}$.

19.The GHG emission reduction measures were assessed based on the costbenefit analysis method. In the period 2015-2020 in Latvia, introducing precision nitrogen management measures in crop production allows reducing $\mathrm{GHG}$ emissions by $205 \mathrm{t} \mathrm{CO}_{2}$ eq.

\section{PROBLEMS AND PROPOSALS FOR THEIR SOLUTION}

The sustainable development of agriculture in Latvia is hindered by several problems, and the author has developed a number of proposals for the tackling of the problems.

Problem 1. Practical and theoretical research investigations into agricultural development and growth extensively use the term sustainable development, yet no accurate theoretical and practical explanations of the term sustainable agricultural development are given.

\section{Proposals}

In future theoretical and practical research investigations, it is advised to use the dissertation's author's definition: "sustainable agricultural development" is convergence towards a balanced situation that takes the form of balanced development of the natural, economic and social environments, which is 
determined by increases in the value of natural, financial, manufactured and human capital in agriculture.

Problem 2. Sustainable agricultural development in the EU is ensured by a synergy between agricultural and environmental policies, the achievement of which is based on the legal acts passed. The legal acts of Latvia have to be enhanced in order to contribute to sustainable agricultural development.

\section{Proposals}

National agricultural, environmental and regional administrative institutions as well as social partners are advised to cooperate and to contribute to a synergy among all the actors engaged in agricultural production and environmental protection. An indicator of agricultural GHG emission intensity has to be included in the indicators of sustainable development in Latvia, and the Rural Development Plan of Latvia for the next programming period has to envisage financial support for the introduction of measures aimed at reducing the GHG emission intensity.

Problem 3. Approximately 400 thou. ha of agricultural land are available for the development and growth of agriculture (crop farming) in Latvia, yet the reintegration of this area into agricultural production contributes to a considerable increase in GHG emissions.

\section{Proposals}

Latvia University of Life Sciences and Technologies has to:

develop an economically and socially feasible system, setting tasks to be performed by responsible national institutions, in order to reintroduce an agricultural area of 275 thou. ha into agricultural production until 2020.

The Ministry of Agriculture of the Republic of Latvia has to:

produce a national programme for 2020 , which envisages that the agricultural area increases by 275 thou. ha, while achieving environmental sustainability targets and GHG emission reduction targets.

Problem 4. The sustainable intensification of crop production reduces impacts on the natural, social and economic environments, yet there are considerable differences among agricultural holdings of diverse economic sizes.

\section{Proposals}

Agricultural governance institutional bodies have to produce an action programme for introducing the principles of sustainable intensification on agricultural holdings according to their economic size. It is useful to employ the methodology for calculation of sustainable intensification developed by the author to assess the development of agricultural holdings. The FADN database has to be extended by indicators showing change in natural capital for the purpose of enhancing sustainable intensification assessments.

\section{Problem 5.}

The introduction of GHG emission reduction measures in crop production contributes to environmental preservation and makes economic benefits for agricultural holdings, yet in the current situation, change in natural capital is 
insufficiently associated with change in the financial capital of agricultural holdings.

\section{Proposals}

Institutional bodies responsible for agricultural governance have to introduce a tool for accounting for, calculation and analysis of GHG emissions for practical use on agricultural holdings, which is linked with the RSS system. An assessment of granting SAP support payments to agricultural holdings has to take into consideration GHG emission intensity per unit of agricultural output.

\section{GALVENO IZMANTOTO AVOTU SARAKSTS / REFERENCES USED IN THE SUMMARY}

1. Alexandratos N., Bruinsma J. (2012) World agriculture towards 2030/2050: the 2012 revision. In: ESA Working paper. pp. 12-03. Rome, FAO. [online] [Accessed: 12.10.2014.].

Retrieved: http://www.fao.org/docrep/016/ap106e/ap106e.pdf

2. Asgedom H., Kebreab E. (2011) Beneficial management practices and mitigation of greenhouse gas emissions in the agriculture of the Canadian Prairie: a review. In: Agronomy Sustainable Development, vol. 31, pp. 433 451.

3. Beckerman W. (1992) Economic growth and the environment: whose growth? whose environment? In: World Development, Vol.20, No. 1, April 1992, pp. 481-496.

4. Bell S., Morse S. (2008) Sustainability Indicators: Measuring the immeasurable. London: Earthscan, $256 \mathrm{p}$.

5. Ceľ̦s uz ilgtspēju: vēsturiskā perspektīva. Sorlina S. Red. (2002) Tulk. J. Zalioksnis (Way towards Sustainability: The Historical Perspective. Ed. Sorlina S. Transl. J. Zalıksnis). Riga: University of Latvia, 2002. 53 p.

6. Diazabakana A., Latruffe L., Bockstaller C., Desjeux Y., Finn J., Kelly E., Ryan M., Uthes S. (2016) A review of farm level indicators of sustainability with a focus on the CAP and FADN. FLINT Report. [online] [Accessed: 11.12.2016.]. Retrieved: http://www.flint-fp7.eu/

7. Eise S. (2012) Between ideologies: the social market economy. [online] [Accessed: 12.10.2016.]. Retrieved: http://www.kas.de/wf/doc/kas_318971522-11-30.pdf?120904143031

8. Eory V., MacLeod M., Topp C.F.E., Rees R.M., Webb J., McVittie A., Wall E., Borthwick F., Watson C., Waterhouse A., Wiltshire J., Bell H., Moran D., Dewhurst R. (2015) Review and update the UK Agriculture Marginal Abatement Cost Curve to assess the greenhouse gas abatement potential for the 5th carbon budget period and to 2050. Scotland's Rural College.

9. Frelih-Larsen A., MacLeod M., Osterburg B., Eory A. V., Dooley E., Kätsch S., Naumann S., Rees B., Tarsitano D., Topp K., Wolff A., Metayer 
N., Molnar A., Povellato A., Bochu J.L., Lasorella M.V., Longhitano D. (2014) Mainstreaming climate change into rural development policy post 2013. Final report. Ecologic Institute, Berlin.

10. Georgescu-Roegen N. (1971) The Entropy Law and the Economic Process. Cambridge, Harvard University Press.

11. Gillis M., Perkins D.H, Roemer M., Radelet S., Snodgrass D.R. (2002) Economics of Development. New York: W.W. Norton \& Company Inc.

12. Haller A.P. (2012) Concepts of Economic Growth and Development. Challenges of Crisis and of Knowledge. In: Economy Transdisciplinarity Cognition, Vol. 15, Issue 1/2012, pp. 66-71.

13. Meadows D.H., Meadows D.L., Randers J. and Behrens W. (1972) The Limits to Growth. London, Earth Island Limited.

14. Modigliani F., Samuelson P. (1966) The Pasinetti Paradox in Neoclassical and More General Models. Review of Economic Studies, vol.33, issue 4, pp. 269. [online] [Accessed: 20.03.2015.] Retrieved: http://piketty.pse.ens.fr/files/ModiglianiSamuelson1966.pdf

15. Noteikumi par ,siltumnīcefekta gāzu emisijas vien̄̄bu inventarizācijas nacionālo sistēmu" noteiktās SEG inventarizācijas nacionālās sistēmas ietvaros (Regulations regarding Greenhouse Gas Inventory Units within the national GHG inventory system). Cabinet Regulation of 27 March 2012 No.217. [online] [Accessed: 20.08.2016].

16. Pilvere I. u.c., (2014) Zemes ekonomiski efektīva, ilgtspējīga un produktīva izmantošana lauksaimniecības un mežsaimniecības produkcijas ražošanai (Economically Efficient, Sustainable and Productive Use of Land for the Production of Agricultural and Forestry Products). Jelgava. [online] [Accessed: 20.10.2016]. Retrieved: http://www.lvm.lv/images/lvm/Petijumi_un_publikacijas/Petijumi/Atskaite zemes_janvaris_gala_2014_1.pdf

17. Pope J., Bond A., Morrison-Saunders A., Retief F. (2013) Advancing the theory and practice of impact assessment: setting the research agenda. Environ Impact Assess.

18. Pretty. J (1997) The sustainable intensification of agriculture. Natural Resources Forum. 21, pp. 247-256.

19. Repetto R. (2010) Economic Impacts of Reducing Greenhouse Gas Emissions. [online] [Accessed: 23.02.2015.] Retrieved: http://www.globalproblems-globalsolutionsfiles.org/pdfs/EC_EconomicImpactsReducingEmissions_Repetto_1004.pdf

20. Rutherford D. (2002) Routledge Dictionary of Economics. Second edition, Routledge. London and New York. 638 p.

21. Schulte R.P.O., Creamer R., Donnellan T., Farrelly N., Fealy R., O'Donoghue C., O'hUallachain D. (2014) Functional land management: a framework for managing soil-based ecosystem services for the sustainable intensification of agriculture. Environ. Sci. Policy, 38, pp. 45-58. [online] 
[Accessed:

Retrieved:

http://www.sciencedirect.com/science/article/pii/S1462901113002104

22. Spangenberg J. (2004) Sustainability Beyond Environmentalism: The Missing Dimensions. GoSD Working Paper No.2 May 2004. [online] [Accessed: 05.03.2014].

Retrieved: http://citeseerx.ist.psu.edu/viewdoc/summary?doi=10.1.1.201.2770

23. Sundar I. (2012) Bioeconomics and Sustainable Development. [online] [Accessed: 05.03.2016].

Retrieved: http://psrcentre.org/images/extraimages/312512.pdf

24. Treisijs M. (1996) Lauksaimniecība un pārtika tirgus ekonomikā (Agriculture and Food in the Market Economy). Riga: LVAEI, 1996. 406 p.

25. Wreford A., Moran D., Adger N. (2010) Climate change in agriculture. Impacts, adaptation and mitigation. OECD. [[online] [Accessed: 05.03.2014]. Retrieved: www.fao.org

26. Alexandratos N., Bruinsma J. (2012) World agriculture towards 2030/2050: the 2012 revision. In: ESA Working paper. pp. 12-03. Rome, FAO. [tiešsaiste] [Skatīts http://www.fao.org/docrep/016/ap106e/ap106e.pdf

27. Asgedom H., Kebreab E. (2011) Beneficial management practices and mitigation of greenhouse gas emissions in the agriculture of the Canadian Prairie: a review. In: Agronomy Sustainable Development, vol. 31, pp. 433451.

28. Beckerman W. (1992) Economic growth and the environment: whose growth? whose environment? In: World Development, Vol.20, No. 1, April 1992, pp. 481-496.

29. Bell S., Morse S. (2008) Sustainability Indicators: Measuring the immeasurable. London: Earthscan, $256 \mathrm{lpp}$.

30. Ceľ̦s uz ilgtspēju: vēsturiskā perspektīva. Sorlina S. Red. (2002) Tulk. J.Zal̨oksnis. Rīga: Latvijas Universitāte, 2002. 53 lpp.

31. Diazabakana A., Latruffe L., Bockstaller C., Desjeux Y., Finn J., Kelly E., Ryan M., Uthes S. (2016) A review of farm level indicators of sustainability witha focus on CAP and FADN. FLINT Report. [tiešsaiste] [Skatīts 11.12.2016.]. Pieejams: http://www.flint-fp7.eu/

32. Eise S. (2012) Between ideologies: the social market economy. [tiešsaiste] [Skatîts 12.10.2016.]. Pieejams: http://www.kas.de/wf/doc/kas_318971522-11-30.pdf?120904143031

33. Eory V., MacLeod M., Topp C.F.E., Rees R.M., Webb J., McVittie A., Wall E., Borthwick F., Watson C., Waterhouse A., Wiltshire J., Bell H., Moran D., Dewhurst R. (2015) Review and update the UK Agriculture Marginal Abatement Cost Curve to assess the greenhouse gas abatement potential for the 5th carbon budget period and to 2050. Scotland's Rural College.

34. Frelih-Larsen A., MacLeod M., Osterburg B., Eory A. V.,Dooley E., Kätsch S., Naumann S., Rees B., Tarsitano D., Topp K., Wolff A., Metayer N., 
Molnar,A., Povellato A., Bochu J.L., Lasorella M.V., Longhitano D. (2014) Mainstreaming climate change into rural development policy post 2013. Final report. Ecologic Institute, Berlin.

35. Georgescu-Roegen N. (1971) The Entropy Law and the Economic Process. Cambridge, Harvard University Press.

36. Gillis M., Perkins D.H, Roemer M., Radelet S., Snodgrass D.R. (2002) Economics of Development. New York: W.W. Norton \& Company Inc.

37. Haller A.P. (2012) Concepts of Economic Growth and Development. Challenges of Crisis and of Knowledge. In: Economy Transdisciplinarity Cognition, Vol. 15, Issue 1/2012, pp. 66-71.

38. Meadows D.H., Meadows D.L.,Randers J. and Behrens W. (1972) The Limits to Growth. London, Earth Island Limited.

39. Modigliani F., Samuelson P. (1966) The Pasinetti Paradox in Neoclassical and More General Models. Review of Economic Studies, vol.33, issue 4, pp. 269. [tiešsaiste] [skatīts 20.03.2015.] Pieejams: http://piketty.pse.ens.fr/files/ModiglianiSamuelson1966.pdf

40. Noteikumi par ,siltumnīcefekta gāzu emisijas vienību inventarizācijas nacionālo sistēmu" noteiktās SEG inventarizācijas nacionālās sistēmas ietvaros. MK 2012. gada 27. marta noteikumi Nr.217. [tiešsaiste] [skatīts 20.08.2016].

41. Pilvere I. u.c., (2014) Zemes ekonomiski efektīva, ilgtspējīga un produktīva izmantošana lauksaimniecības un mežsaimniecības produkcijas ražošanai. Jelgava. [tiešsaiste] [skatīts 20.10.2016]. Piejams: http://www.lvm.lv/images/lvm/Petijumi_un_publikacijas/Petijumi/Atskaite zemes_janvaris_gala_2014_1.pdf

42. Pope J., Bond A., Morrison-Saunders A., Retief F. (2013) Advancing the theory and practice of impact assessment: setting the research agenda. Environ Impact Assess.

43. Pretty. J (1997) The sustainable intensification of agriculture. Natural Resources Forum. 21, pp. 247-256.

44. Repetto R. (2010) Economic Impacts of Reducing Greenhouse Gas Emissions. [tiešsaiste] [skatīts 23.02.2015.] Pieejams: http://www.globalproblems-globalsolutions-

files.org/pdfs/EC_EconomicImpactsReducingEmissions_Repetto_1004.pdf

45. Rutherford D. (2002) Routledge Dictionary of Economics. Second edition, Routledge. London and New York. 638 pp.

46. Schulte R.P.O., Creamer R.,Donnellan T., Farrelly N., Fealy R., O'Donoghue C., O'hUallachain D. (2014) Functional land management: a framework for managing soil-based ecosystem services for the sustainable intensification of agriculture. Environ. Sci. Policy, 38, pp. 45-58. [tiešsaiste] [skatîts 20.08.2016]. Pieejams:http://www.sciencedirect.com/science/article/pii/S1462901113002 104 
47. Spangenberg J. (2004) Sustainability Beyond Environmentalism: The Missing Dimensions. GoSD Working Paper No.2 May 2004. [tiešsaise] [skatîts 05.03.2014]. Pieejams: http://citeseerx.ist.psu.edu/viewdoc/summary?doi=10.1.1.201.2770

48. Sundar I. (2012) Bioeconomics and Sustainable Development. [tiešsaise] [skatīts 05.03.2016]. Pieejams: http://psrcentre.org/images/extraimages/312512.pdf

49. Treisijs M. (1996) Lauksaimniecība un pārtika tirgus ekonomikā. Rīga: LVAEI, 1996. - 406 lpp.

50. Wreford A., Moran D., Adger N. (2010) Climate change in agriculture. Impacts, adaptation and mitigation. OECD. [tiešsaise] [skatīts 05.03.2014]. Pieejams: www.fao.org 